\title{
Juliana Sanajotti Nakamuta
}

Terapia celular para isquemia cardíaca: efeitos da via de administração, do tempo pós-lesão e do uso de biopolímero para a retenção das células e função miocárdica

Tese apresentada à Faculdade de Medicina da Universidade de São Paulo para obtenção do título de Doutor em Ciências.

Área de Concentração: Cardiologia

Orientador: Prof. Dr. José Eduardo Krieger

São Paulo 
Dados Internacionais de Catalogação na Publicação (CIP)

Preparada pela Biblioteca da

Faculdade de Medicina da Universidade de São Paulo

Creprodução autorizada pelo autor

Nakamuta, Juliana Sanajotti

Terapia celular para isquemia cardiaca : efeitos da via de administração, do tempo pós-lesão e do uso de biopolímero para a retenção das células e função miocárdica / Juliana Sanajotti Nakamuta. -- São Paulo, 2008.

Tese(doutorado)--Faculdade de Medicina da Universidade de São Paulo.

Departamento de Cardio-Pneumologia.

Área de concentração: Cardiologia.

Orientador: José Eduardo Krieger.

Descritores: 1.Terapia tissular 2.Infarto do miocárdio 3.Células da medula óssea 4.Fibrina 5.Função ventricular

USP/FM/SBD-355/08 
Este trabalho foi desenvolvido no Laboratório de Genética e Cardiologia Molecular (LGCM) do Instituto do Coração (InCor) da Faculdade de Medicina da Universidade de São Paulo (FMUSP) e recebeu apoio financeiro da Fundação de Amparo à Pesquisa do Estado de São Paulo (FAPESP), Conselho Nacional de Desenvolvimento Científico e Tecnológico (CNPq), Financiadora Nacional de Estudos e Projetos (FINEP) e Fundação Zerbini. 
Esta tese está de acordo com as seguintes normas, em vigor no momento desta publicação:

Referências: adaptado de International Commitee of Medical Journals Editors (Vancouver)

Universidade de São Paulo. Faculdade de Medicina. Serviço de Biblioteca e Documentação. Guia de apresentação de dissertações, teses e monografias. Elaborado por Anneliese Carneiro da Cunha, Maria Julia de A. L. Freddi, Maria F. Crestana, Marinalva de Souza Aragão, Suely Campos Cardoso, Valéria Vilhena. $2^{\mathrm{a}}$. Ed. São Paulo: Serviço de Biblioteca e Documentação; 2005.

Abreviaturas dos títulos dos periódicos de acordo com List of Journals Indexed in Index Medicus. 
MEUS PAIS, Fumio e Regina, pelos princípios que têm orientado minha vida e pelo incentivo constante

MEUS IRMÃOS, Adriana e Paulo, pelo companheirismo incondicional

Os MESTRES que participaram da construção e desenvolvimento de meu conhecimento científico

A AMIGA Maria Elena Danoviz, pela responsabilidade científica fundamental à minha formação 
Essa tese representa o trabalho de uma equipe. A colaboração de cada um dos componentes foi fundamental para que ela pudesse ser concluída com êxito. Meus sinceros agradecimentos:

Ao meu orientador Prof. Dr. José Eduardo Krieger, que desde o princípio acreditou em minha capacidade para desenvolver esses e outros projetos através da disponibilização de recursos, do incentivo nos momentos de fracasso e dos ensinamentos que guiaram minha conduta ao encontro do objetivo principal dessa trajetória: a formação científica. Obrigada por ter compartilhado e confiado a co-orientação de alunos de iniciação científica; essa atividade foi fundamental para meu progresso científico.

À minha amiga e parceira profissional Maria Elena Danoviz. Agradeço pelo companheirismo em todas as instâncias, pela dedicação que teve com meu trabalho, pelos ensinamentos freqüentes e principalmente por despertar em mim a "essência" da ciência na ocasião em que foi criticada pelos seus comentários a respeito de ciclo celular e, a partir de então, desenvolveu um estudo para provar que nossas culturas de células estavam repletas de células binucleadas ao contrário de células em divisão, como lhe tinham casualmente dito na época.

Ao Dr. Fábio L. Navarro Marques do laboratório de radiofarmácia da Faculdade de Medicina da Universidade de São Paulo, que apoiou completamente esse estudo. 
A um grupo especial e fundamental de amigos e colaboradores: Vinicius Bassaneze, Gabriel Ribeiro dos Santos Junior, Danilo Saint-Clair e Giancarlo Fatobene. Obrigada pelo apoio constante e pelos experimentos com células-tronco do tecido adiposo. Essa tese também pertence a vocês!

À Dra. Kellen C. Faé e Carolina Lavini do laboratório de imunologia deste instituto, pelos experimentos de citometria de fluxo; obrigada pela compreensão e disponibilização de vosso preciso tempo com meus experimentos.

Ao Prof. Dr. Paulo J. F. Tucci, ao Leonardo dos Santos, Edinei L. Antônio e à Alexandra Alberta pela colaboração com os experimentos de função cardíaca

Ao Dr. Luis Henrique Wolf Gowdak pelos sábios comentários críticos a respeito desse trabalho e por ter sido completamente solícito em diferentes ocasiões.

Aos meus pais Fumio e Regina que desejaram ver seus sonhos realizados nos meus! Obrigada pelo amor e pelo apoio incondicional em cada etapa da minha vida.

Aos meus irmãos Adriana e Paulo por me permitirem sentir amor por outra pessoa tal como por mim mesma. Obrigada pelo companheirismo e pelos momentos de muita alegria! 
À Raquel Sirvente pelos exames de ecocardiografia. Obrigada pela dedicação e respeito com nosso estudo e pelo esforço incondicional para a realização de cada exame ao longo desses anos. Todo nosso esforço valeu!

Ao Dr. Paulo S. L. Oliveira por ter sido responsável pelo meu contato com o meu orientador e principalmente, pelo voto de confiança no meu profissionalismo.

À minha prima Alexandrina L. Oliveira pelo apoio fundamental à minha chegada em São Paulo. Sem sua preciosa ajuda essa tese poderia ter tido outra história.

Ao Leandro Cardoso e Newton Lopes pelo auxílio nos procedimentos cirúrgicos experimentais.

Ao amigo Rafael Dariolli pela ajuda com os experimentos nos momentos finais. Obrigada pela paciência, compreensão e dedicação.

À minha amiga Dra. Luciene C. Gastalho Campos pelas preciosas informações, pelos esclarecimentos e pela atitude solícita em qualquer circunstância!

Ao amigo Márcio Chaves pelo apoio técnico fundamental para os estudos histológicos dessa tese. Obrigada pelo empenho constante e pela paciência comigo!

Ao amigo Dr. Márcio C. Bajgelman pelos experimentos de citometria de fluxo. 
À Dra. Ayumi A. Miyakawa pelas discussões de resultados, revisões, esclarecimentos e pela amizade.

À Mariliza Velho e Daniela Jardim pelos experimentos com PCR em tempo real. Mari, obrigada pela dedicação e por ter sido tão prestativa com meu trabalho. À Samantha Omae pelo auxílio com as hibridizações e cultura de células.

Ao Dr. Isolmar T. Shettert pelo apoio com o fornecimento de fibrina e por ter se demonstrado sempre prestativo.

À Dra. Ana Lúcia Garippo pelo auxílio técnico com os experimentos de imunofluorescência e confocal. Obrigada pela amizade, por todas as dicas, e por ter sido tão prestativa.

À Dra. Lisete, Dra. Milena e Carlos do grupo de pneumologia desse instituto, pelos ensaios de ELISA.

À Silvana Campos e Isabel Cristina Lameirinhas pelo auxílio com os trâmites dos projetos e pela amizade.

Aos amigos Dona Antônia, Arruda e Marcos, pela colaboração com a limpeza e organização dos materiais. Obrigada também pelos momentos divertidos! 
A todos os amigos que contribuíram de diferentes formas para a realização desse trabalho: Gustavo J. Justo, Tiago V. Pereira, Kátia M. Gomes, Valério G. Baraúna, Thaís Girão, Thaíz Borin, Renata Carmona, José Xavier Neto, Allysson Sampaio, Hozana A. Castillo, Marcilene Floriano, Noely Ferreira e Maria de Lourdes Junqueira.

Aos ANIMAIS que foram sacrificados para que esse estudo pudesse ser desenvolvido. A eles caberia uma sessão especial, porém o significado de sua importância é plenamente contemplado pelo respeito aqui declarado e pela seriedade com que esse trabalho foi conduzido.

À FAPESP pelo apoio financeiro.

A Deus pela presença em minha vida. Com Ele sentimos que a força para recomeçar está dentro de nós! 
Esta tese de doutoramento está organizada conforme o seu desenvolvimento durante os últimos quatro anos. Nesse sentido ela contempla dois estudos independentes na área de terapia celular que foram desenvolvidos de maneira concomitante durante esse curso. São estudos que abordam questões de fundamental importância na área de terapia celular para a doença isquêmica cardíaca.

O primeiro deles foi desenhado com o objetivo de avaliar parâmetros que podem influenciar a retenção cardíaca de células transplantadas em modelo animal de isquemia cardíaca. Esse estudo foi realizado com células da medula óssea e testou o efeito do tempo após o infarto do miocárdio e da via de administração dessas células sobre o acúmulo cardíaco das mesmas. Adicionalmente avaliamos a eficácia do uso de matriz de fibrina, um biopolímero, como veículo para otimizar a retenção das células. As implicações da variação da retenção de células sobre a função cardíaca também foram consideradas.

Num outro contexto, considerando a célula como agente terapêutico, testamos o uso de células-tronco derivadas do tecido adiposo, previamente submetidas ao "shear stress”, em animais infartados. Esse estudo está em fase de finalização e os principais resultados dele foram organizados de maneira concisa e serão apresentados como anexo dessa tese. 


\section{Sumário}

Índice de Figuras ....................................................................................................................................vi

Índice de Tabelas ....................................................................................................................................viii

Lista de Siglas ..........................................................................................................................................

Lista de Símbolos ....................................................................................................................................

Resumo …..............................................................................................................................................

Abstract ...........................................................................................................................................

1. INTRODUÇÃO.............................................................................................................................

1.1. Terapia celular em cardiopatias - uma nova abordagem...............................................01

1.2. Medula óssea: um órgão reconhecido como fonte de células para a terapia celular.

1.3. Retenção cardíaca de células-tronco transplantadas - fatores que podem influenciar na

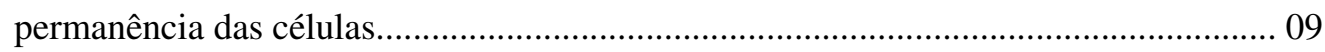

1.3.1. O papel das vias de administração.....................................................................11

1.4. Infarto agudo do miocárdio: mecanismos celulares e moleculares da resposta inflamatória.

1.5. Organização espacial e temporal dos fatores que governam o homing de células da medula óssea após o IAM - uma possível janela para intervenção em terapia

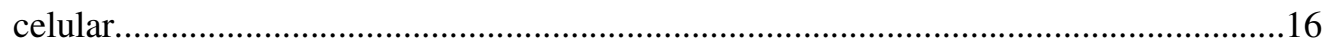

1.5.1. Homing: um processo de múltiplas etapas.......................................................19

1.6. Matrizes de biopolímeros na medicina regenerativa.................................................... 24

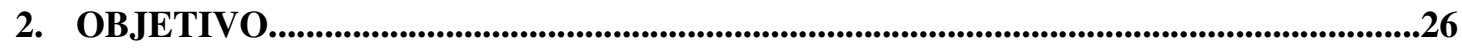

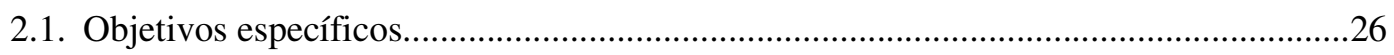

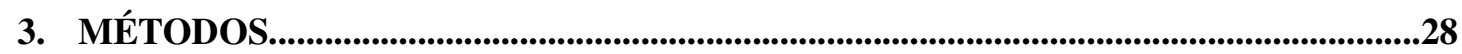

3.1. Procedimentos cirúrgicos experimentais..................................................................28 


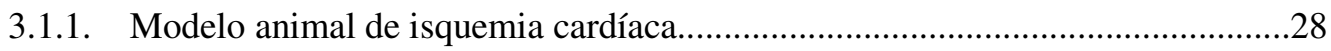

3.1.2. Vias de administração Células da Medula Óssea ( $\left.{ }^{99 \mathrm{~m}} \mathrm{Tc}-\mathrm{CMO}\right)$........................29

3.2. Radiometria nuclear.....................................................................................................30

3.2.1. Avaliação da radioatividade nos órgãos coletados dos animais que receberam células da medula óssea marcadas radioativamente $\left({ }^{99 \mathrm{~m}} \mathrm{Tc}-\right.$

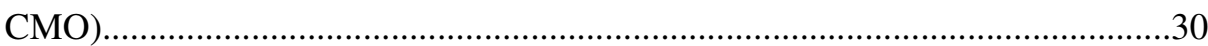

3.2.2. Captação de metabólitos do marcado ${ }^{99 \mathrm{~m}} \mathrm{Tc}-\mathrm{CMO}$ no coração............................31

3.3. Cultura de células e ensaios in vitro..........................................................................................31

3.3.1. Isolamento das células da medula óssea e

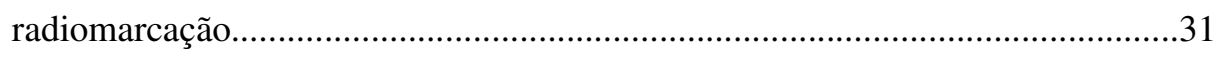

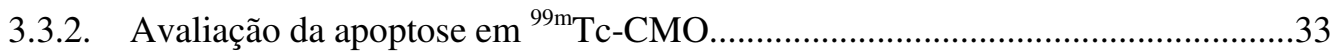

3.3.3. Extração e cultura primária de células-tronco do tecido adiposo............................34

3.3.4. Extração e cultura primária de fibroblastos cardíacos.............................................35

3.3.5. Transdução de fibroblastos cardíacos com vetor adenoviral contendo a proteína

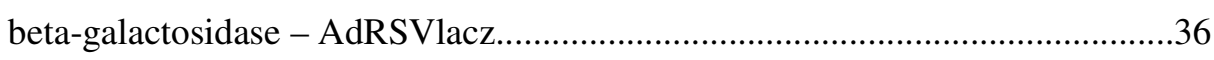

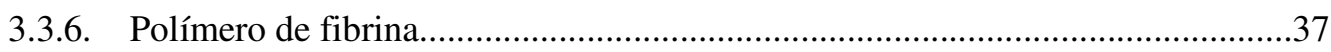

3.4. Avaliação histológica.....................................................................................................................37

3.4.1. Medidas - infarto do miocárdio, espessura da cicatriz e perímetro do ventrículo

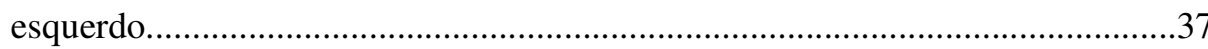

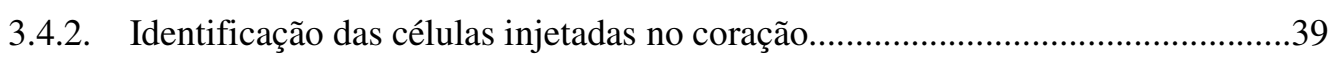

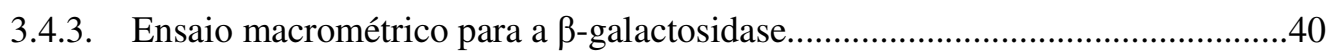

3.3. Avaliação da função cardíaca........................................................................................40

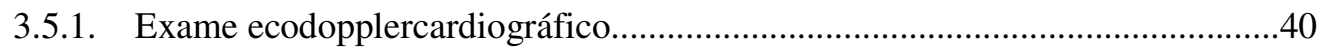

3.5.2. Estudo hemodinâmico da função cardíaca.......................................................... 41

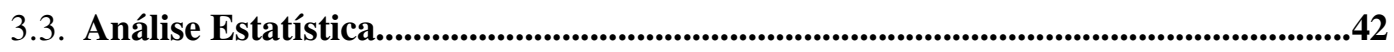

\section{RESULTADOS}

4.1. Eficiência, estabilidade e citotoxicidade da radiomarcação em células da medula

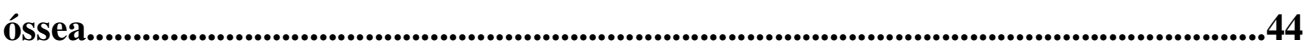

4.2. Acúmulo cardíaco das células da medula óssea..............................................................46

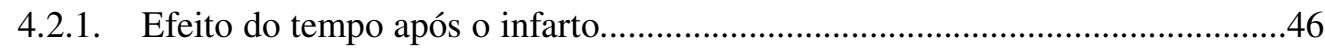


4.2.2. Efeito da via de administração das células. .49

4.3. Biodistribuição das células da medula óssea......................................................52

4.4. Veículo de biopolímero como uma estratégia para melhorar a retenção cardíaca das células transplantadas nas primeiras 72 horas após o

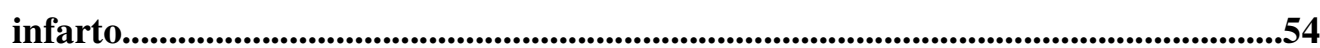

4.5. Efeito das diferenças na retenção das células da medula óssea sobre a função cardíaca de ratos infartados..............................................................................59

4.5.1. Avaliação morfométrica dos corações..................................................60

4.5.2. Avaliação hemodinâmica da função ventricular........................................66

5. DISCUSSÃO .82

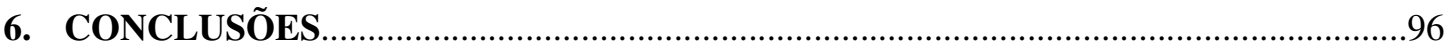

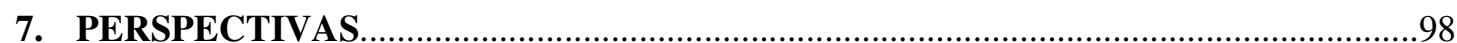

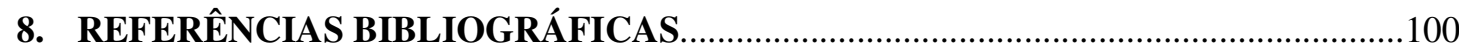

ANEXO I - Uso de células-tronco do tecido adiposo previamente estimuladas com "shear stress" para o reparo do infarto do miocárdio em ratos.

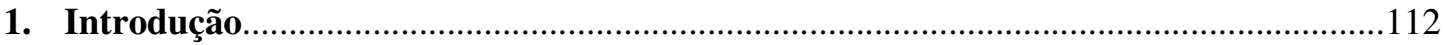

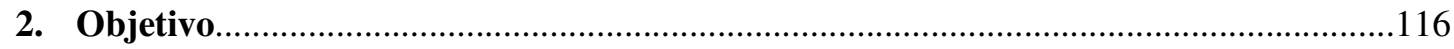

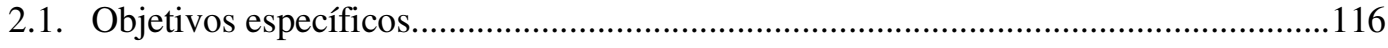

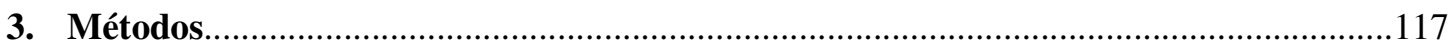

3.1 Cultura de células...................................................................................117

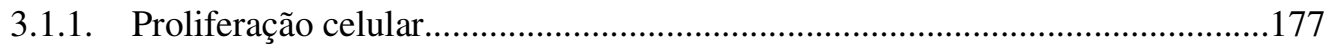

3.1.2. Diferenciação das células-tronco do tecido adiposo.....................................118

3.1.3. Coloração "Oil red”" para adipócitos........................................................119

3.1.4. Ensaio de Von Kossa para osteócitos......................................................119

3.1.5. Estimulação de células-tronco do tecido adiposo com "shear stress"..............120

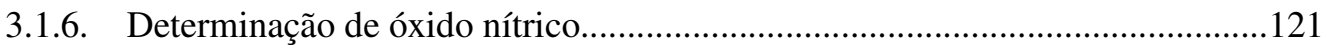

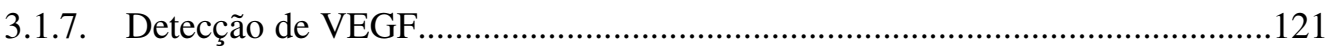


3.1.8. Ensaio de formação de estruturas tubulares através de matrigel

3.2 Expressão gênica..................................................................................................123

3.2.1. Extração de RNA....................................................................................123

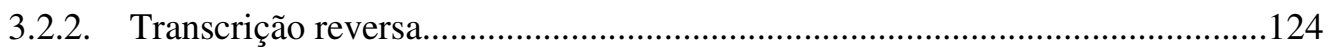

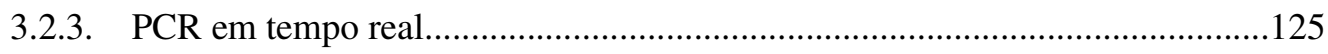

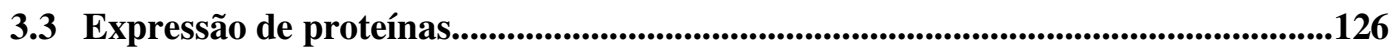

3.3.1. Análise quantitativa da expressão protéica por citometria de fluxo....................126

3.4 Estudo in vivo com células-tronco do tecido adiposo.....................................................128

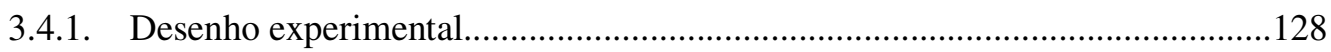

3.4.2. Extração de colágeno a partir da cauda de ratos................................................129

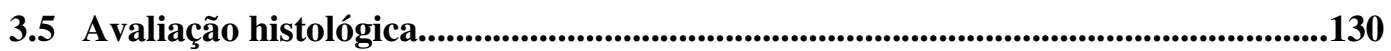

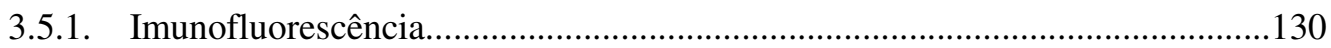

4. Resultados

4.1 Caracterização das células-tronco do tecido adiposo..............................................132

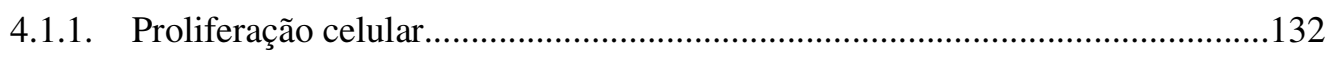

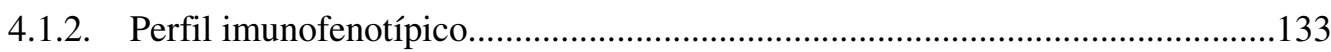

4.1.3. Plasticidade das células-tronco do tecido adiposo..........................................135

4.2 Efeito do "shear stress" em células-tronco do tecido adiposo - morfologia, expressão gênica e protéica....................................................................................................137

4.2.1. "Shear stress" promove mudança da morfologia das células-tronco do tecido adiposo..

4.2.2. "Shear stress" induz a expressão de CD31, Flk-1 e VWf em células-tronco do tecido adiposo. 138

4.3 Efeito do "shear stress" sobre a produção de VEGF e óxido nítrico em célulastronco do tecido adiposo.

4.4 "Shear stress" promove a formação de estruturas tubulares em células-tronco do tecido adiposo.

4.5 Efeito do uso de células-tronco do tecido adiposo, previamente estimuladas com "shear stress", sobre o reparo do infarto do miocárdio em ratos.

4.5.1. Avaliação morfométrica - tamanho de infarto, perímetro do ventrículo esquerdo e espessura da cicatriz.

4.5.2. Avaliação hemodinâmica da função cardíaca - medidas de pressão intraventricular, de contratilidade e desempenho cardíaco. 
4.6 Células-tronco do tecido adiposo injetadas no coração infartado expressam marcadores de células endoteliais in vivo...............................................................157

5. Discussão..........................................................................................................................................162

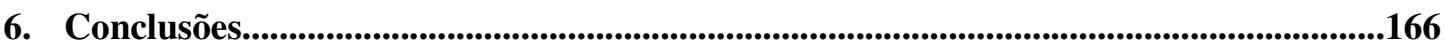

7. Referências bibliográficas............................................................................................167

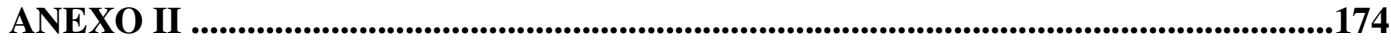

ANEXO III .............................................................................................................................................196

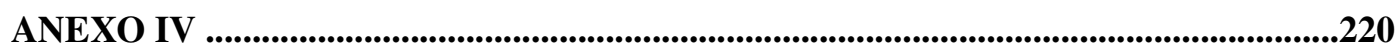

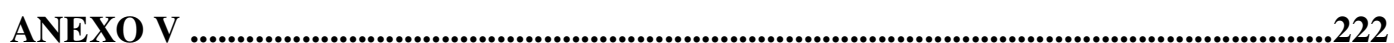




\section{Índice de Figuras}

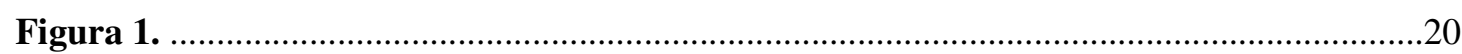

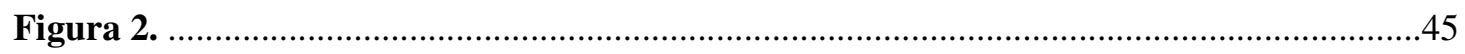

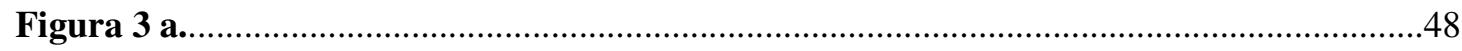

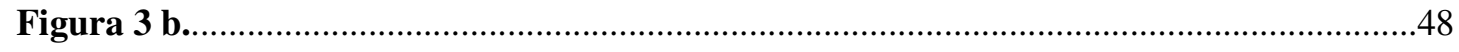

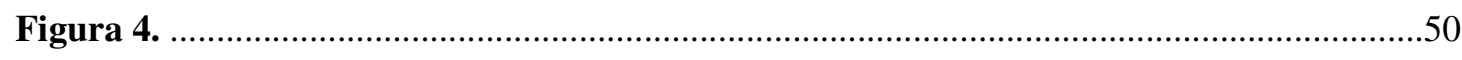

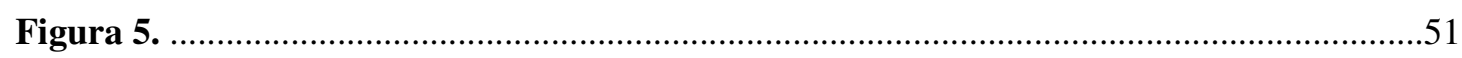

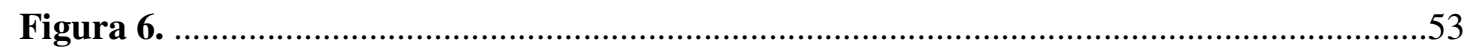

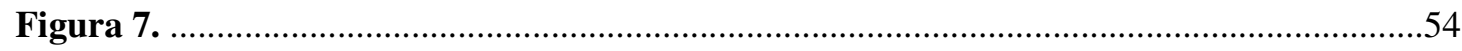

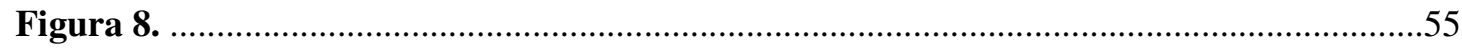

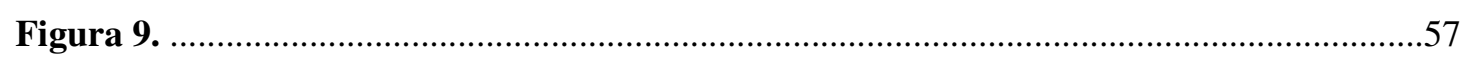

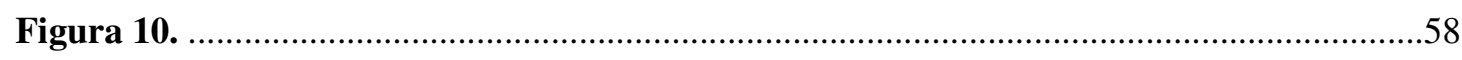

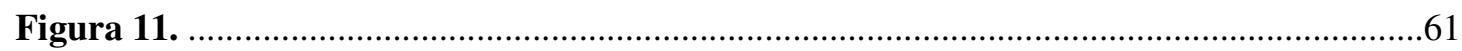

Figura 12. …

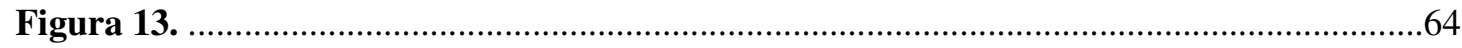

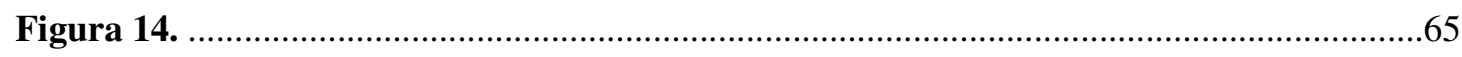

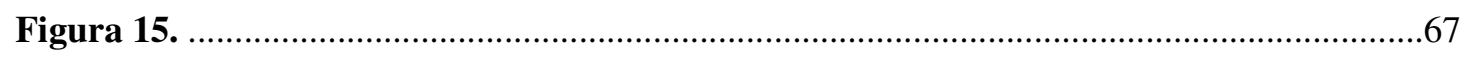

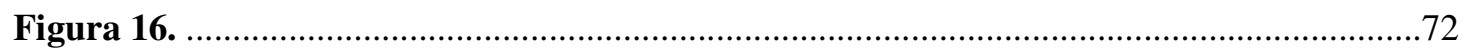

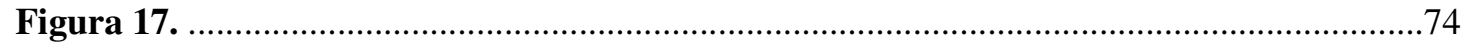

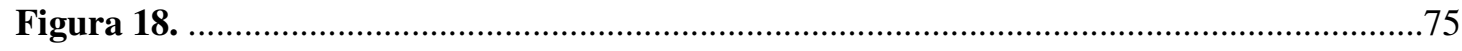

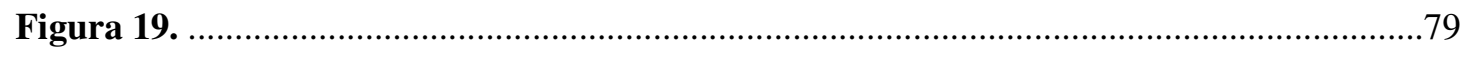

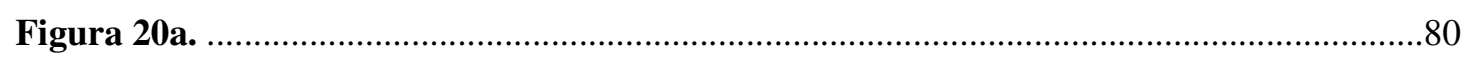

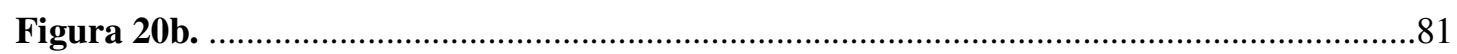

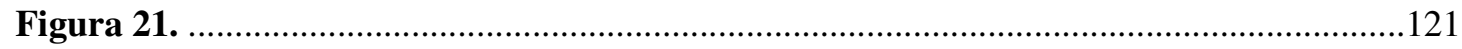

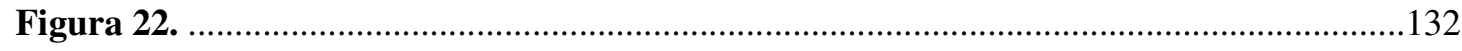

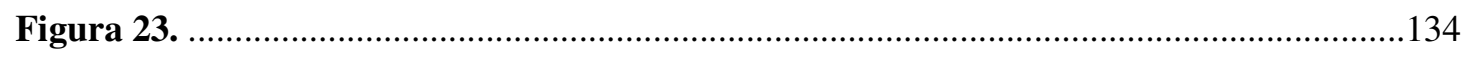

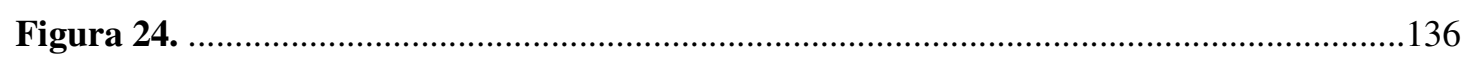

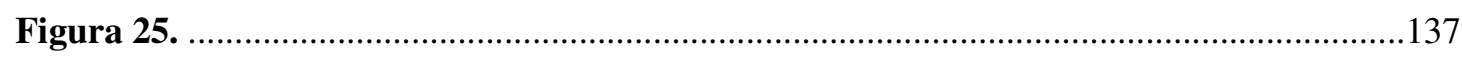

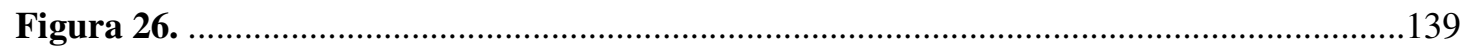

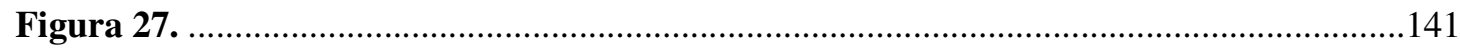




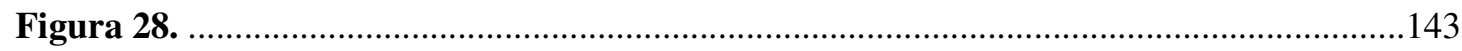

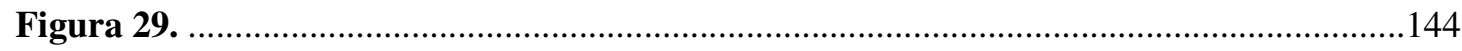

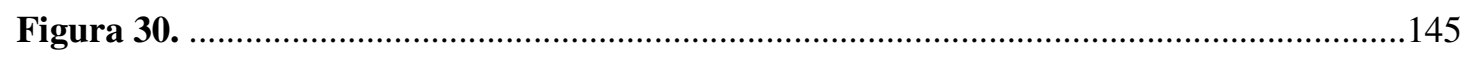

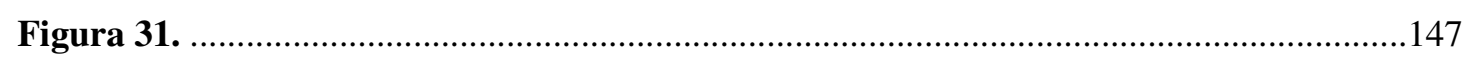

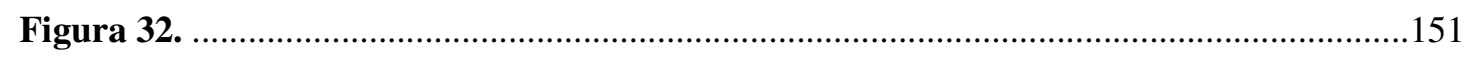

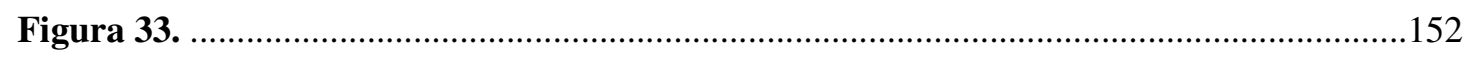

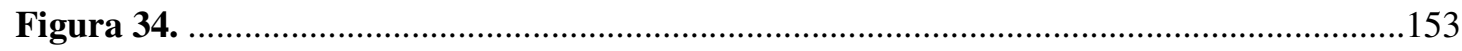

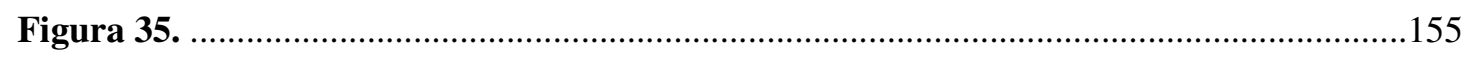

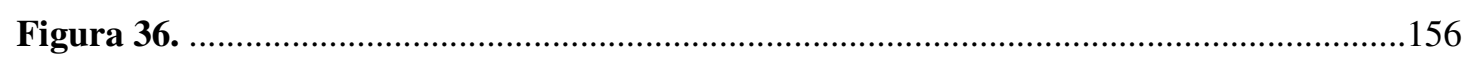

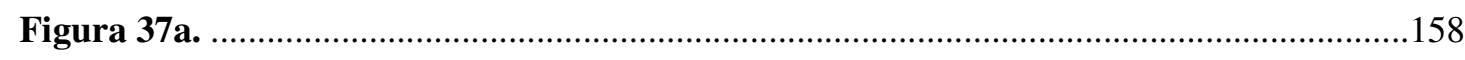

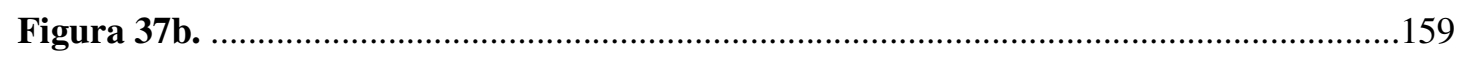

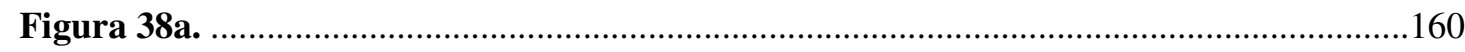

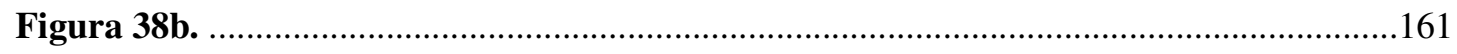




\section{Índice de Tabelas}

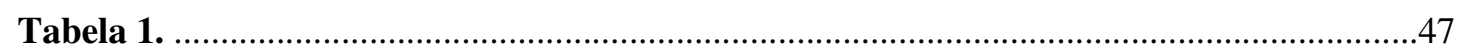

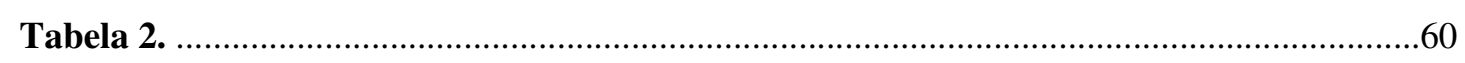

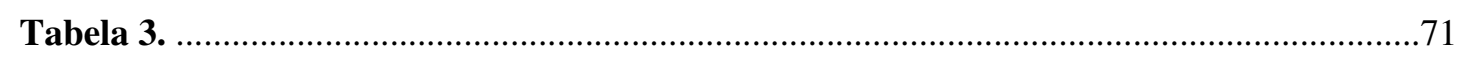

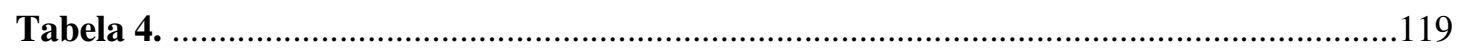

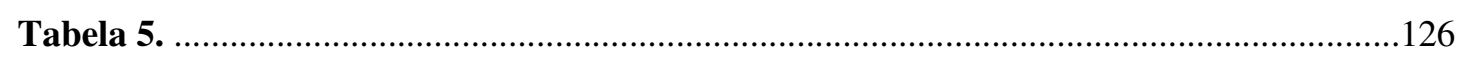

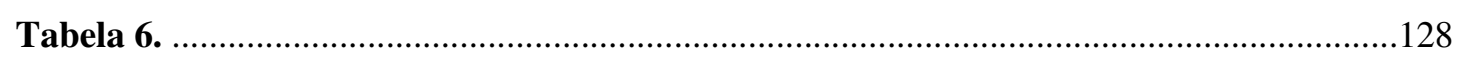

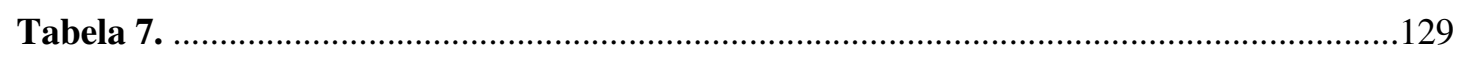

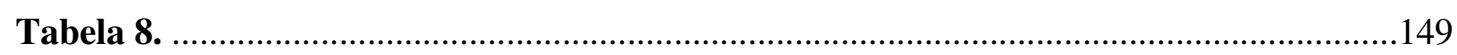


LISTA DE SIGLAS

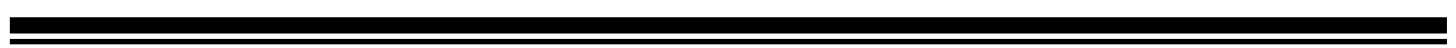




\section{Lista de siglas}

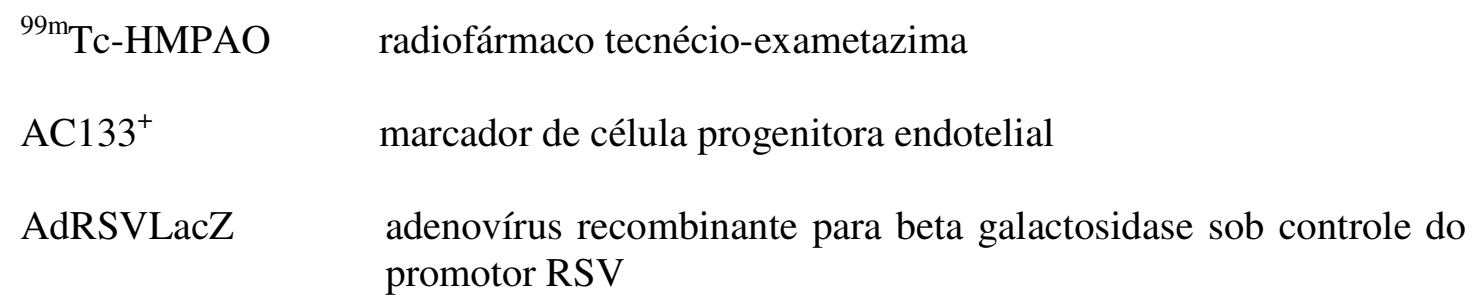

CM-DiI marcador fluorescente citoplasmático (Chloromethylbenzamido Dil)

$\mathrm{CO}_{2} \quad$ gás carbônico

COL colágeno tipo I

CTTA células-tronco do tecido adiposo

CXCR4 receptor para SDF-1 $(C-X-C$ chemokine receptor type 4$)$

DAPI marcador fluoresente de núcleo celular (4'6 - Diamine-2phenylindole dihydrochloride) 
DMEM

DMEM L

DNA

dNTPs

DTT

E e P selectinas

EDTA

ELISA

FACS

FBS

FC

FENIL

FGF

FITC

FS

G-CSF

HBSS

i.p.

IC

IC

ICAM
Dulbecco’s Modified Eagle’s médium

Dulbecco's Modified Eagle's médium low glucose

ácido desoxirribonucléico

desoxirribonucleotídeos trifosfato

dithiothreitol

moléculas de adesão (integrinas) em células endoteliais

sal dissódico do ácido etilenodiaminotetraacético (disodium ethylenediaminetetra acetate)

enzyme linked immuno sorbent assay

Fluorescence activated cell sorting

soro fetal bovino (fetal bovine serum)

freqüência cardíaca

fenilefrina

fator de crescimento de fibroblasto (fibroblast growth factor)

fluoresceína isocyannate

fosfatidilserina

fator de estimulação de colônia de granulócito (granulocyte colony stimulation factor)

solução salina balanceada de Hanks (Hank's balanced salt solution)

intraperitoneal

via de administração intracavitária

índice cardíaco

molécula de adesão intercelular (intercellular adhesion molecule) 
ICO

IL-1 $\alpha$, IL-1 $\beta$

IL-6 IL-8

IM

IPEN-CNEN

ITS

IV

IVSE

$\mathrm{KCl}$

$\operatorname{Lin}^{-}$

LTSC

L-selectina

MAPCs

$\mathrm{MgCl}_{2}$

MMP-1

MMP-9

$\mathrm{NaCl}$

NO

$\mathrm{P} / \mathrm{S}$

PBS

PCR via de administração intracoronariana

interleucinas $1 \alpha, 1 \beta, 6$ e 8 .

via de administração intramiocárdica

Instituto de Pesquisas Energéticas e Nucleares - Comissão Nacional de Engenharia Nuclear

índice do trabalho sistólico

via de administração intravenosa

índice do volume sistólico ejetado

cloreto de potássio

indica que a célula não expressa proteínas características de células de linhagens diferenciadas de um determinado órgão (linhagem negativa)

long term stem cells

molécula de adesão (integrina) em neutrófilos

células progenitoras adultas multipotentes (multipotent adult progenitor cells)

cloreto de magnésio

metaloproteinase 1 (metalloproteisase-1)

metaloproteinase 9 (metalloproteinase-9)

cloreto de sódio

óxido nítrico

$1 \%$ penicilina $\mathrm{G}(100 \mathrm{U} / \mathrm{ml})$ e estreptomicina $(100 \mu \mathrm{g} / \mathrm{ml})$

phosphate-buffered saline

polymerase chain reaction 
PDfVE

PE

PECy5

PerCPE

PI

PSVE

RNA

ROS

RT

Sca-1

SCF

SDF-1

SS

STSC

TAE

TNF- $\alpha$

UV

VCAM

VE

VEGF

VEGFR2 ${ }^{+}$

vWf pressão diastólica final no ventrículo esquerdo

phycoeritrin

phycoeritrin Cy5

Peridinin-chlorophyll phycoeritrin

propidium iodete

pressão sistólica no ventrículo esquerdo

ácido ribonucleico

espécies reativas de oxigênio (reactive oxigen species)

transcriptase reversa

proteína expressa por células-tronco (stem cell antigen-1)

glicoproteína envolvida na hematopoiese (stem cell factor)

fator 1 derivado de células estromais (stromal - derived factor 1)

shear stress

short term stem cells

tris acetato EDTA

fator $\alpha$ de necrose tumoral (tumoral necrosis factor $\alpha$ )

luz ultravioleta

molécula-1 de adesão celular vascular (vascular cell adhesion molecule-1)

ventrículo esquerdo

fator de crescimento do endotélio vascular (vascular endothelial growth factor)

receptor FLK-1 para VEGF

fator de Von Willebrand, fator VIII 
x-gal

$\beta$-gal

$+\mathrm{dP} / \mathrm{dt}_{\max }$

$-\mathrm{dP} / \mathrm{dt}_{\mathrm{Max}}$

substrato da enzima beta - galactosidase (5-bromo-4-chloro-3indolyl-beta-D-galacto-pyranoside)

enzima beta galactosidase

derivada temporal máxima positiva

derivada temporal máxima negativa 
LISTA SÍMBOLOS

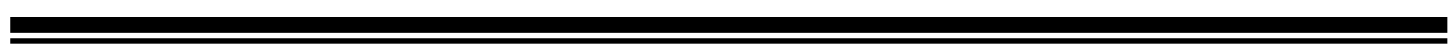




\section{Lista de símbolos}

\begin{tabular}{|c|c|}
\hline \# & número \\
\hline$\%$ & percentagem \\
\hline$>\mathrm{e}<$ & maior e menor \\
\hline \pm & mais ou menos \\
\hline bat & batimento \\
\hline $\mathrm{cm}^{2}$ & centímetro quadrado \\
\hline $\mathrm{dL}$ & decilitro \\
\hline EPM & erro padrão da média \\
\hline $\mathrm{g}$ & grama \\
\hline$g$ & gravidade \\
\hline GBq & gigabequerel \\
\hline $\mathrm{kg}$ & kilograma \\
\hline $\log$ & logarítmo \\
\hline $\mathrm{MBq}$ & mega becquerel \\
\hline M & molar \\
\hline $\mathrm{mCi}$ & miliCurie \\
\hline $\mathrm{mg}$ & miligrama \\
\hline $\min$ & minuto \\
\hline $\mathrm{mL}$ & mililitro \\
\hline $\mathrm{mm}$ & milímetro \\
\hline $\mathrm{mM}$ & milimolar \\
\hline
\end{tabular}




\begin{tabular}{|c|c|}
\hline $\mathrm{mm} \mathrm{Hg}$ & milímetro de mercúrio \\
\hline $\mathrm{nm}$ & nanômetro \\
\hline${ }^{\circ} \mathrm{C}$ & grau Celsius \\
\hline$p$ & coeficiente de significância estatística \\
\hline $\mathrm{pH}$ & potencial hidrogeniônico \\
\hline pg & picograma \\
\hline s & segundo \\
\hline UI & unidades internacionais \\
\hline $\mathrm{vol} / \mathrm{vol}$ & volume/volume \\
\hline vs. & versus \\
\hline $\mathrm{V}$ & volts \\
\hline $\mathrm{x}$ & vezes \\
\hline$\alpha$ & ângulo em rad \\
\hline$\mu \mathrm{g}$ & micrograma \\
\hline$\mu \mathrm{L}$ & microlitro \\
\hline$\mu \mathrm{m}$ & micrômetro \\
\hline$\mu \mathrm{M}$ & micromolar \\
\hline$\eta$ & coeficiente de viscosidade em dinas. $\mathrm{s} / \mathrm{cm}^{2}$ \\
\hline$\omega$ & velocidade angular em rad. $\mathrm{s}^{-1}$ \\
\hline $\mathrm{rad}$ & radianos \\
\hline$\tau$ & $\operatorname{dinas} / \mathrm{cm}^{2}$ \\
\hline
\end{tabular}




\section{Resumo}

\section{Nakamuta J. S. Terapia celular para isquemia cardíaca: efeitos da via de administração, do tempo pós-lesão e do uso de biopolímero para a retenção das} células e função miocárdica [tese]. São Paulo: Faculdade de Medicina, Universidade de São Paulo; 2008. 225p.

A terapia celular representa uma abordagem promissora para o tratamento de cardiopatia isquêmica, porém aspectos-chave dessa estratégia permanecem incertos. Neste trabalho avaliamos a eficiência da retenção cardíaca de células da medula óssea marcadas com tecnécio ( $\left.{ }^{99 \mathrm{~m}} \mathrm{Tc}-\mathrm{CMO}\right)$ transplantadas, de acordo com o tempo após o infarto $(1,2,3$ e 7 dias) e a via de administração dessas células (intravenosa [IV], intraventricular [IC], intracoronariana [ICO] e intramiocárdica [IM]), em ratos submetidos à isquemiareperfusão cardíaca [I\&R]. Após 24 horas, a retenção cardíaca de ${ }^{99 \mathrm{~m}} \mathrm{Tc}-\mathrm{CMO}$ foi maior na via IM comparada com a média alcançada pelas demais $(6,79 \%$ do total injetado vs. $0,53 \%)$. O uso de fibrina como veículo para a injeção de células incrementou a retenção em 2.5 vezes $(17,12$ vs. $6,84 \%)$ na via IM. Curiosamente, quando administradas após 7 dias, a retenção de células na via IM alcançou valores próximos dos observados com da matriz de fibrina injetadas 24 h após a I\&R (16,55 vs. 17,12\%), enquanto que para as demais vias as mudanças foram insignificantes. Nos animais em que as CMO foram administradas por via intramiocárdica 24 horas após a I\&R, com ou sem fibrina, observou-se melhora significante do desempenho cardíaco frente ao estresse farmacológico com fenilefrina quando comparados aos controles. Em conjunto, os dados mostram a biodistribuição das células injetadas após a I\&R por 4 diferentes vias e 4 intervalos de tempo pós-lesão e indicam que a via IM é a que produz maior retenção cardíaca. O uso do biopolímero de fibrina aumenta a retenção das células e a eficácia deste efeito sobre a função cardíaca e mortalidade dos animais em longo prazo, além de 30 dias pós $I \& R$, merecerá ser investigada no futuro.

Descritores: 1.Terapia tissular 2. Infarto do miocárdio 3. Células da medula óssea 4. Fibrina 5. Função ventricular 
ABSTRACT

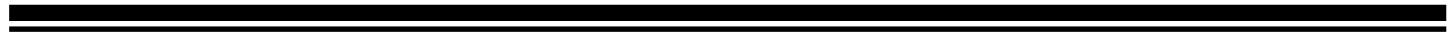




\begin{abstract}
Nakamuta J. S. Cell therapy for ischemic cardiac disease: effect of different routes for cell administration, time post-mi and the use of a fibrin polymer for cardiac cell retention and myocardial function [thesis]. São Paulo: Medical School, University of
\end{abstract} São Paulo; 2008. 225p.

Cell therapy represents a promising approach for ischemic cardiac disease, but key aspects of this strategy remain unclear. We examined the effects of timing and route of administration of bone marrow cells (BMCs) after myocardial ischemia/reperfusion injury (I\&R). $99 \mathrm{mTc}$-labeled BMCs were injected by 4 different routes: intravenous (IV), left ventricular cavity (LV), left ventricular cavity with temporal aorta occlusion $(\mathrm{LV}+)$ and intramyocardial (IM). The injections were performed 1, 2, 3, or 7 days after infarction. Cardiac retention was higher following the IM route compared to the average values obtained by all other routes $(6.79 \%$ of the total radioactivity injected vs. $0.53 \%)$. Use of a fibrin biopolymer as vehicle during IM injection led to a 2.5 -fold increase in cardiac cell accumulation (17.12 vs. $6.84 \%)$. Interestingly, the retention of cells administered with culture medium at day 7 post-MI by the IM route was similar to that observed when cells were injected $24 \mathrm{~h}$ post-IM using fibrin (16.55 vs $17.12 \%)$, whereas no significant changes were observed for the other routes. Cell therapy 24 hs post MI by IM injection, with or without fibrin, resulted in comparable improvement in cardiac function under pharmacological stress compared to control animals. Together, we provide evidence for the biodistribution of ${ }^{99 \mathrm{~m}} \mathrm{Tc}$-labeled BMCs injected post MI by 4 different routes and times post-injury, which shows that the IM rout is the most effective for cardiac cell retention. The use of a fibrin biopolymer further increased cardiac cell retention and its potential long term benefits, beyond 30, on reducing mortality and improving cardiac function deserve to be explored in the future.

Descriptors: 1. Cell therapy 2. Myocardial infarction 3. Bone marrow cells 4. Fibrin 5. Cardiac function 
INTRODUÇÃO

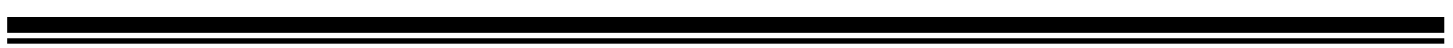




\subsection{Terapia Celular em Cardiopatias - Uma Nova Abordagem}

A isquemia do miocárdio associada à doença coronariana é a principal causa de morbidade e mortalidade nos EUA ${ }^{1}$. No Brasil, dados do Ministério da Saúde (DATASUS-MS) apontam que, no ano de 2005, dos 1.006 .827 óbitos, 28,20\% foram causados por doenças do aparelho circulatório, das quais o infarto agudo do miocárdio (IAM) aparece como a principal causa de mortalidade, com a ocorrência de 64.455 óbitos. Segundo estimativas da Organização Mundial da Saúde, cerca de 20 milhões de pessoas em todo o mundo sofrem de doenças cardiovasculares, particularmente de infarto do miocárdio, das quais 12 milhões são vítimas fatais. Através desses dados, é presumível que os investimentos na elaboração de novas formas de tratamento das doenças cardiovasculares exerceriam grande impacto na redução da taxa de mortalidade.

Nas últimas décadas observou-se um grande avanço no tratamento da doença arterial oclusiva baseando-se na utilização de medicamentos e em técnicas de revascularização cirúrgica ou por angioplastia. Ainda assim, o grande desafio é tentar evitar o remodelamento ventricular e a falência cardíaca decorrentes da isquemia miocárdica. 
A possibilidade de impedir a cicatrização fibrótica e as complicações funcionais decorrentes dela através da regeneração celular do tecido cardíaco tem levado diversos grupos de pesquisa a estudar a possibilidade do uso da terapia celular para recuperar os cardiomiócitos perdidos durante um evento isquêmico ${ }^{2-4}$.

Orlic e Anversa em 2001 foram os pioneiros a demonstrar que células-tronco hematopoiéticas participavam da regeneração do miocárdio infartado de camundongos, através da geração de novo de cardiomiócitos e componentes vasculares ${ }^{5,6}$. A formação de novas células foi capaz de diminuir a área da cicatriz de fibrose e melhorar a função cardíaca nesses animais. A redução da área fibrótica em modelo animal de infarto agudo do miocárdio foi também descrita por outros grupos de pesquisadores ${ }^{7-9}$. No ano seguinte, Assmus e colaboradores publicaram o primeiro estudo clínico com célulastronco em humanos (TOPCARE-AMI) ${ }^{10}$. Foram observados efeitos benéficos após a infusão de células da medula óssea na artéria relacionada ao infarto sobre o processo de remodelamento, ainda considerando que o estudo era de fase I, destinado inicialmente à avaliação da segurança da aplicação de tal técnica. Outros estudos clínicos envolvendo o uso de células-tronco derivadas de diferentes fontes para o tratamento de doença isquêmica cardíaca têm sido conduzidos por pesquisadores de todo o mundo ${ }^{11-13}$. 
A partir desses relatos, uma série praticamente inesgotável de estudos surgiu apontando para os efeitos positivos estruturais e funcionais sobre o miocárdio infartado, decorrentes do uso de células-tronco.

Todavia, os mecanismos de ação dessas células foram contestados por outros autores, os quais propuseram que as células formadas de novo eram derivadas da fusão das células transplantadas com células cardíacas residentes ou simplesmente não adotavam fenótipo cardíaco-específico ${ }^{8 ; 14-16}$. Sinalização parácrina das células-tronco transplantadas sobre outras células no miocárdio também foi proposto como mecanismo de ação dessas células que pudesse explicar o êxito do emprego terapêutico dessas.

Concomitantemente, foram testadas outras populações de células, incluindo grupos específicos da própria medula óssea, células da medula de origem nãohematopoiética (células mesenquimais ou estromais) bem como células de outros órgãos adultos como as células mesenquimais de tecido adiposo, cardiomiócitos, músculo esquelético, entre outros ${ }^{17-19}$.

Assim, os estudos disponíveis a respeito da finalidade terapêutica das célulastronco apontam para uma mesma direção que é a necessidade da compreensão de mecanismos básicos e fundamentais. Nesse sentido, o foco atual das pesquisas com células-tronco está direcionado aos estudos que buscam avaliar questões de ciência básica, como a biologia das células-tronco, que ainda não foram contempladas, e que são fundamentais para a implementação dessa abordagem terapêutica. 
A escassez da investigação de ciência básica relacionada à terapia com célulastronco, reflete o domínio dos centros de pesquisa aplicada nessa temática, cuja preferência por estudos com potencial aplicação denota a exigência do sistema de saúde ${ }^{4}$. Tal voracidade por resultados que justifiquem a aplicação dessa tecnologia biológica, tem corrompido a clara necessidade da investigação científica. Por outro lado, conforme foi mencionado, os estudos voltados à fundamentação teórica e conceitual têm ganhado espaço, inclusive para que as centenas de resultados encontrados com a utilização terapêutica de células-tronco ao longo desses anos possam ser interpretadas e conduzam a conclusões concisas.

Torna-se evidente, portanto, que a implantação dessa abordagem no cenário clínico requer a compreensão de uma série de aspectos-chave tais como via de administração para o transplante das células-tronco, o tipo celular a se empregado, a compreensão dos múltiplos mecanismos de ação das células implantadas, o momento “ideal” para o transplante das células, a sobrevida das células após a enxertia e seu comportamento em longo prazo, o aprimoramento de técnicas que permitam acompanhar as células por longo tempo, a elaboração de estudos multicêntricos com desenho experimental adequado para a interpretação dos resultados, a avaliação da colonização das células transplantadas em órgão não-alvos da terapia, entre outros.

Dentre as principais questões a serem investigadas destacam-se àquelas relacionadas à retenção das células transplantadas no órgão-alvo, dos quais o momento adequado e a(s) 
via(s) de administração mais apropriada (s) para o transplante das células são de particular valor para maximizar a eficiência do transplante.

\subsection{Medula Óssea: Um Órgão Reconhecido como Fonte de Células para a Terapia Celular}

O conhecimento acerca da constante renovação celular que ocorre na medula óssea auxilia na compreensão da participação das células indiferenciadas desse órgão na regeneração de outros órgãos adultos.

É sabido que na medula óssea a renovação celular seja da porção medular ou da estromal, ocorre com elevada freqüência ${ }^{20,21}$. A hematopoiese garante a reposição diária de hemácias bem como de células das linhagens linfóide e mielóide. Também são requeridos osteoblastos dada a constante degradação do estroma ósseo por osteoclastos. A garantia da elevada demanda de renovação celular é a existência e permanência de uma população indiferenciada de células. Essas células, conhecidas como células-tronco da medula óssea, a despeito das variações na nomenclatura, guardam duas características importantes que as definem como tais células. Cada uma dessas, ao se dividir, gera uma célula que guarda as características da célula-mãe e permanece quiescente e outra que está destinada ao comprometimento com uma linhagem celular. Esse comportamento é proposto como característica peculiar de células-tronco. 
Ainda que o racional seja conceber que essas células sejam do reservatório para uso da própria medula óssea, ou seja, destinadas à participação apenas nesse órgão, estudos recentes têm mostrado que: ou essas células são plásticas no sentido de se adequarem ao microambiente de outros órgãos, ou a medula óssea é um grande reservatório sistêmico que mantém precursores de diferentes origens. Kucia e colaboradores em 2004 mostraram a existência de células progenitoras tecidoespecíficas residentes na medula óssea. Células com fenótipo de precursores cardíacos também foram descritas e seriam mobilizadas através da circulação para o miocárdio após isquemia cardíaca ${ }^{22,23}$.

Os estudos propondo o uso de terapia celular para o tratamento de patologias onde há degeneração ou perda tecidual, têm sido desenvolvidos utilizando diferentes populações de células-tronco encontradas na medula ou até mesmo o conjunto de todas as células desse órgão, conhecido como células da medula óssea não-fracionadas 5;7;10;39;42;44. O conjunto das células não-fracionadas da medula óssea compreende populações em diferentes níveis de maturação; àquelas consideradas mais indiferenciadas, as quais são uma percentagem muito pequena do conjunto das células, as células progenitoras linfohematopoiéticas e também as células diferenciadas e maduras (eritrócitos, linfócitos e as demais células desse órgão) ${ }^{24 ; 25}$.

Os tipos celulares isolados da medula óssea cujo potencial terapêutico têm sido investigado em estudos de terapia celular incluem: 
- $\quad$ células-tronco hematopoiéticas com capacidade proliferativa por longo período de tempo (long term stem cells, LTSC);

- células-tronco hematopoiéticas com capacidade proliferativa por curto período de tempo (short term stem cells, STSC);

- células-tronco mesenquimais: células-tronco não-hematopoiéticas também conhecidas como estromais, raras e concentradas na medula óssea. Esta população de células é heterogênea e destacam-se nesse grupo as MAPCs (multipotent adult progenitor cells);

- células progenitoras: essas células apresentam marcadores de linhagens como o antígeno CD34, uma glicoproteína que indica imaturidade linfohematopoiética ${ }^{24}$. Em contrapartida, apresentam marcadores fenotípicos característicos de célulastronco como o c-kit (tirosina quinase), uma proteína de membrana cuja função é de proliferação, migração e diferenciação celular e o Sca-1 (stem cell antigen - 1), marcador de superfície com função de adesão, sinalização e ativação de células-tronco.

Embora haja controvérsia sobre o uso de células derivadas da medula óssea para o reparo de outros órgãos, a pesquisa experimental e clínica com diferentes populações obtidas da medula óssea estão bastante difundidas. Numerosos estudos em modelos animais de cardiopatia isquêmica bem como os clínicos envolvendo seres humanos apresentaram efeitos positivos após o uso de populações de células-tronco obtidas da medula óssea. Os efeitos benéficos observados, vão desde a recuperação estrutural e regenerativa do coração e a angiogênese até a melhora funcional do órgão. 
O grupo de Anversa demonstrou a presença de cardiomiócitos de novo em corações de camundongos submetidos à isquemia cardíaca, originados a partir de

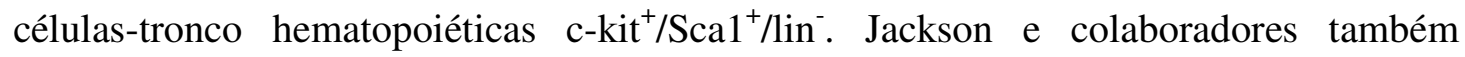
descreveram a participação de células-tronco hematopoiéticas $\mathrm{CD}^{+} 4^{+} / \mathrm{c}^{-\mathrm{kit}^{+} / \mathrm{Sca}^{+}}{ }^{\text {na }}$ regeneração do músculo cardíaco isquêmico de camundongos. Essas células contribuíram para a angiogênese e para a formação de novos cardiomiócitos ${ }^{26}$.

O crescente número de estudos publicados na última década deixou claro que, embora ainda não seja possível explicar sobre os mecanismos que regem as respostas observadas com o uso das células-tronco hematopoiéticas, a utilização dessas células é factível e segura, pelo menos com relação aos aspectos vitais avaliados agudamente $6 ; 8 ; 9 ; 40 ; 61-64$

Seguramente, a compreensão dos possíveis mecanismos de ação dessas e de células-tronco de outras fontes, a padronização de protocolos de aplicação das células e a avaliação em longo prazo do efeito dessas células no organismo, serão imprescindíveis para que a abordagem da medicina regenerativa por meio da terapia celular seja realidade na prática clínica. 


\subsection{Retenção Cardíaca de Células-Tronco Transplantadas - Fatores que Podem Influenciar na Permanência das Células}

Os efeitos das células-tronco transplantadas, a despeito do tipo celular, dependem, em última análise, da permanência dessas células no órgão-alvo. A presença e permanência das células-tronco precedem sua sobrevida e, conseqüentemente, os efeitos derivados dela, quais sejam, a proliferação, a diferenciação/transdiferenciação assim como a secreção de proteínas por essas células. É desejável, por essa razão, que essas células estejam viáveis e permaneçam junto ao órgão-alvo.

Nesse sentido, dois momentos seqüenciais são pré-requisitos fundamentais para o sucesso da terapia celular: (1) o acesso das células ao órgão-alvo (método alequeado para a administração das células e acesso, viabilização de espaço físico que as comporte no órgão, etc.) e (2) a manutenção das células transplantadas no tecido (resposta inflamatória do microambiente - sinalização para homing e morte -, adaptação ao novo microambiente, capacidade do microambiente fornecer condições de estadia para essas células considerando a disponibilidade de nutrientes e oxigênio).

Observações relativamente recentes demonstraram que a perda de células que ocorre durante e após o transplante é elevada; cerca de 50\% das células já são eliminadas ou perdidas durante o procedimento de transplante ${ }^{17}$. Essa perda pode estar relacionada, especialmente no caso do coração, ao washout pelo sistema vascular coronariano ${ }^{27}$. 
Nesse sentido, as vias de administração das células podem ter uma implicação importante.

A hostilidade do microambiente cardíaco em decorrência da resposta inflamatória na isquemia também participa em grande parte da eliminação das células transplantadas. Sob esse aspecto, a busca pela provável “janela de intervenção”, na qual a inflamação e o recrutamento de células-tronco da medula óssea estejam equilibrados é de particular interesse. Além disso, ainda que o microambiente seja favorável à sobrevida das células transplantadas, a morte por apoptose de muitas delas por razões de adaptabilidade deve ser também computada. Enfim, a percentagem das células-tronco transplantadas que pode exercer alguma função benéfica para o coração acometido por isquemia é bastante reduzida, podendo chegar a menos de $25 \%$ da quantidade inicial ${ }^{17}$.

Abordar os fatores que influenciam diretamente na retenção de células durante a terapia celular para as cardiopatias isquêmicas representa o cumprimento de uma etapa de estudo importante para o sucesso e implementação dessa proposta terapêutica na prática clínica. A questão sobre a retenção de células-tronco transplantadas foi contemplada no presente estudo à luz da cinética das moléculas quimioatrativas durante o curso da resposta inflamatória e a possível influência das vias de administração utilizadas para o transplante das células nesse processo. 


\subsubsection{O Papel das Vias de Administração}

Uma variedade de vias de administração de células tem sido testada para o transplante de células-tronco, incluindo a transepicárdica ou intramiocárdica ${ }^{39-41}$, sistêmica ${ }^{42-44}$, intracoronariana baseada em cateter-balão ${ }^{10,12 ; 45-47}$. Entretanto, estudos comparativos desenhados para avaliar a eficiência das vias são escassos.

Diferentes mecanismos podem contribuir para a retenção de células-tronco no coração acometido por lesão isquêmica.

Fisiologicamente, o homing é um processo constante na medula óssea e pode estar implicado na mobilização de células-tronco hematopoiéticas durante o processo inflamatório conforme já foi explanado. Esse é um mecanismo que depende completamente da ativação e atração das células para o local sinalizador. Nesse sentido, para esse mecanismo, em teoria, qualquer que seja a via de entrega das células, o direcionamento ao órgão-alvo estará garantido desde que as etapas precedentes ao homing propriamente dito sejam cumpridas.

Por outro lado, cada modalidade de administração de células pode ter uma capacidade intrínseca de contribuir em maior ou menor grau para o simples acúmulo de células no coração. Assim, a avaliação combinada dos fatores relacionados à mobilização, homing e retenção de células-tronco em órgãos lesados é fundamental. É possível que o momento "ótimo" para terapia varie de acordo com a da via de administração empregada para o transplante das células, principalmente devido a potenciais diferenças no mecanismo de acúmulo das células. Por exemplo, a via 
sistêmica deve ser igualmente dependente de fatores relacionados à mobilização e ao homing, enquanto que a via intramuscular é fundamentalmente dependente dos processos de homing e retenção das células no tecido a ser reparado.

Assim, o momento adequado para o transplante de células deverá ser avaliado dentro do contexto da modalidade da via de administração como o objetivo de otimizar a eficiência do mecanismo predominante em cada via.

\subsection{Infarto Agudo do Miocárdio - Mecanismos Celulares e Moleculares da Resposta Inflamatória}

A interrupção do fluxo sanguíneo em uma ou mais artérias coronarianas define, resumidamente, o infarto agudo do miocárdio. A conseqüência desse evento é a privação de sangue, um fluido vital responsável pelo transporte de gases e moléculas orgânicas essenciais para a geração de energia nas células. Essa condição isquêmica leva à morte das células perfundidas pelo leito arterial acometido, caso a reperfusão não ocorra dentro de poucos minutos. Do ponto de vista fisiopatológico, a isquemia tem como conseqüência a ativação imediata de um processo inflamatório cujo grau de intensidade varia de acordo com o tempo e grau de isquemia ${ }^{28}$.

A resposta inflamatória é iniciada pela ativação do sistema do complemento. $\mathrm{O}$ complemento é ativado por fragmentos de membrana e conteúdo intracelular dos cardiomiócitos mortos por necrose. A presença de componentes do sistema do 
complemento amplifica o recrutamento de células inflamatórias para o local da isquemia através, principalmente, do incremento de citocinas pró-inflamatórias. Nessa fase inicial, destaca-se também a participação das espécies reativas de oxigênio (ROS) geradas pelo desequilíbrio de óxido-redução resultante da inibição da troca gasosa via fluxo sanguíneo ${ }^{29}$. O papel pró-inflamatório das ROS é evidente pela elevação do número de leucócitos locais ${ }^{30,31}$.

Fatores de transcrição são ativados pelas células envolvidas na isquemia, dos quais o NF-kB destaca-se por induzir a expressão de citocinas importantes nesse processo como o TNF- $\alpha$ e interleucinas pró-inflamatórias (IL-1 $\alpha$, IL-1 $\beta$, IL-6, IL-8). A coordenada ativação desses mediadores químicos garante a efetividade da resposta inflamatória. Como resultado, a mediação celular da resposta inflamatória é iniciada com a infiltração principalmente de neutrófilos. A interleucina 8 é uma das principais citocinas responsáveis pela migração de neutrófilos. Estudos mostram que quanto mais acentuados os níveis dessa quimiocina, maior o número de neutrófilos atraídos para o local da lesão. Ademais, quando o miocárdio isquêmico é reperfundido, a concentração dessa citocina é ainda maior, o que pode explicar o caráter hostil da reperfusão ${ }^{31}$.

Os neutrófilos recrutados pela cascata de ativação quimioatrativa, atingem o tecido isquêmico cardíaco através da interação com as células endoteliais da vasculatura local. Ambos os tipos celulares interagem através de moléculas de adesão expressas por essas células. Receptores para selectinas E e P das células endoteliais presentes em neutrófilos medeiam o contato inicial dessas células. A seguir, ICAM, uma proteína de 
adesão intercelular presente na membrana plasmática de células endoteliais e cardiomiócitos, liga-se a um complexo proteico de integrinas (integrina $\beta 2$ ou CD18, CD11a, CD11b) da membrana dos neutrófilos e, finalmente, adentra no millieu do tecido cardíaco. Nesse local, os neutrófilos promovem a degradação da matriz extracelular através da síntese e liberação de metaloproteinases, especialmente MMP-9.

A digestão da matriz extracelular é concomitante à maturação de monócitos em macrófagos para a fagocitose desses componentes digeridos e das células mortas. Sequencialmente, fatores de crescimento como o FGF e VEGF estimulam miofibroblastos a diferenciarem-se em fibroblastos secretórios. Finalmente, a colonização da região eliminada pela isquemia por fibroblastos e a secreção de colágeno por essas células, constituirão o novo tecido local.

A resposta inflamatória frente à isquemia cardíaca é um processo benéfico por solucionar o problema estrutural da perda de tecido cardíaco. Em contrapartida, é inevitável a adaptação do coração cicatrizado frente ao novo constituinte do tecido cardíaco. Essa adaptação, em quase todos os casos, é traduzida no remodelamento cardíaco e, nesse sentido, em detrimento do reparo estrutural, a inflamação não é satisfatória.

O remodelamento é a condição onde a morfologia anatômica do ventrículo esquerdo é alterada em decorrência da ineficiência da função do tecido cardíaco enquanto bomba propulsora. Nesse cenário, a insuficiência cardíaca, é a resultante 
inevitável do infarto do miocárdio não letal. Em resumo, o infarto do miocárdio leva à perda de tecido e ao prejuízo do desempenho cardíaco. Assim, a melhor terapêutica para evitar o remodelamento é a regeneração dos cardiomiócitos bem como a estimulação da neovascularização dentro da área infartada.

Finalmente, conforme a descrição fisiopatológica do processo inflamatório decorrente do infarto do miocárdio é pertinente um comentário nessa sessão. A cinética dos mediadores químicos e celulares que regulam a resposta inflamatória pode fornecer informações importantes para a elaboração de estratégias que visem o reparo tecidual.

Muitos dos fatores envolvidos com o processo inflamatório têm um papel importante sobre o homing de células-tronco hematopoiéticas para o local da isquemia, inclusive os mesmos, por apresentarem ações pleiotrópicas, podem influenciar os dois processos em momentos diferentes. Assim, os limites entre a promoção da inflamação e o reparo celular são tênues e isso, impulsiona a busca por possíveis janelas de intervenção durante o curso da resposta inflamatória. 


\subsection{Organização Espacial e Temporal dos Fatores que Governam o Homing de Células da Medula Óssea após o IAM - Uma Possível Janela para Intervenção em Terapia Celular}

No contexto da resposta inflamatória que se segue à isquemia cardíaca, a complexidade dos eventos vai além do pleiotropismo da rede de moléculas envolvidas. Citocinas, quimiocinas e fatores de crescimento têm sua ação controlada temporalmente, e isso pode ser observado através dos níveis locais dessas moléculas que variam durante o curso do processo inflamatório ${ }^{28,32}$.

A explicação para a participação de células indiferenciadas da medula óssea no processo de reparo cardíaco pode ser compreendida à luz do comportamento e regulação dos fatores quimioatrativos encontrados durante o desencadeamento do processo inflamatório. Nesse sentido, os fatores envolvidos com o recrutamento de células da medula óssea para o coração durante esse processo também cursam com níveis que variam com o tempo ${ }^{33-35}$. A despeito de sua função quimioatrativa sobre células inflamatórias linfomononucleadas, fatores como G-CSF, SDF-1, interleucina 8 (IL-8), SCF entre outros, desempenham um papel importante na modulação do processo de reparo cardíaco mediado por células indiferenciadas residentes na medula óssea ${ }^{30,34}$.

De fato, essas moléculas são supra-reguladas após o evento isquêmico cardíaco ${ }^{28,31}$. Shintani e colaboradores demonstraram uma relação temporal entre o infarto agudo do miocárdio (IAM) em humanos e a mobilização de células $\mathrm{CD} 34^{+}$, uma população de 
células-tronco hematopoiéticas. Essa mobilização foi incrementada ao longo das horas consecutivas ao infarto e atingiu um pico no sétimo dia após o evento isquêmico. Concomitantemente, os níveis de VEGF, FGF e G-CSF estavam aumentados nesse intervalo. No mesmo ano, Gill e colaboradores relataram uma elevação rápida e transiente de células VEGFR2 ${ }^{+} \mathrm{AC}_{133^{+}}$no sangue de indivíduos acometidos por trauma vascular $^{36}$. Essa mobilização ocorreu imediatamente após a lesão e foi transitória, ou seja, houve uma correlação positiva entre o incremento no número dessas células circulantes e o tempo após a lesão. Segundo esse trabalho, essa correlação estava diretamente relacionada ao aumento de VEGF nas primeiras 72 horas, que diminuiu já no sétimo dia após a lesão vascular.

Em 2003, Askari e colaboradores estudando o efeito de um fator específico (SDF-1) sobre a migração de células da medula óssea ao coração isquêmico, demonstraram que o miocárdio expressou SDF-1 em níveis incrementados em decorrência de um insulto isquêmico ${ }^{37}$. Ademais, os níveis locais desse fator variaram com o tempo. Nas primeiras vinte e quatro horas a concentração desse fator quimioatrativo era maior e diminuiu nas horas seguintes até o desaparecimento no sétimo dia após a lesão.

No ano seguinte, o grupo de Abbott também descreveu um papel importante do SDF-1 no recrutamento de células da medula óssea em modelo animal de infarto agudo do miocárdio ${ }^{34}$. Nesses animais, a expressão de SDF-1 no coração aumentou 
progressivamente nas primeiras setenta e duas horas e diminuiu no sétimo dia. Houve uma correlação positiva entre o incremento de SDF-1 local e a mobilização de células $\mathrm{CXCR}^{+}$da medula para o miocárdio isquêmico. Esses pesquisadores também demonstraram que a expressão de SDF-1 induzida por vetor viral em cardiomiócitos de corações sadios, não era suficiente para o recrutamento das células da medula.

Os estudos supramencionados, em conjunto, corroboram a proposta de que a expressão de determinados fatores, especialmente àqueles relacionados à mobilização endógena de células da medula óssea, apresentam uma cinética regulada temporalmente, dentro de uma limitada janela de tempo, em última análise, transitória ${ }^{34,37,38}$. Interessantemente, um outro fator comum a esses estudos é a interpretação de que, provavelmente, a deficiência de regeneração cardíaca esteja intimamente relacionada à "intensidade do sinal de homing" para as células da medula óssea. Se a medula for de fato um órgão mantedor de populações de células com certo grau de plasticidade, órgãos como o coração, poderiam ser considerados geradores de sinais de homing ineficientes. Por outro lado, sob a óptica da evolução, o coração a priori não tem necessidade de renovação celular constante. Isso poderia explicar a baixa porcentagem de células precursoras residentes nesse órgão e a sua limitada capacidade regenerativa. Neste contexto, especularíamos que há órgão(s) que funcionam como reservatório central de células para o reparo de tecidos adultos, especialmente daqueles que têm baixa capacidade de renovação celular e fazem uso de células indiferenciadas ou precursoras de outros órgãos. 
Finalmente, a despeito da posição hierárquica quanto à maturidade das célulastronco adultas, é constatável que o coração, em decorrência de lesão por isquemia, sintetiza fatores relacionados ao tráfego de células da medula óssea via corrente sanguínea e que esse processo é transitório. Esses achados certamente instigam a investigação em direção à identificação do "momento ideal" para o transplante de células.

\subsubsection{Homing: um processo de múltiplas etapas}

O homing de células-tronco para o local da lesão de um órgão adulto é um processo complexo, seqüencial e fisiologicamente orquestrado de recrutamento de células. Citocinas, quimiocinas, fatores de crescimento e moléculas de adesão, são sinalizadores fundamentais para a mobilização das células-tronco da medula óssea, circulação via corrente sanguínea, transmigração e adesão no órgão lesado ${ }^{21}$. Para que esse processo seja efetivo, é imprescindível que não haja interrupcção em nenhuma das etapas relacionadas. A figura 1 ilustra esquematicamente as fases do processo de homing de células-tronco hematopoiéticas ao coração lesado por isquemia. 


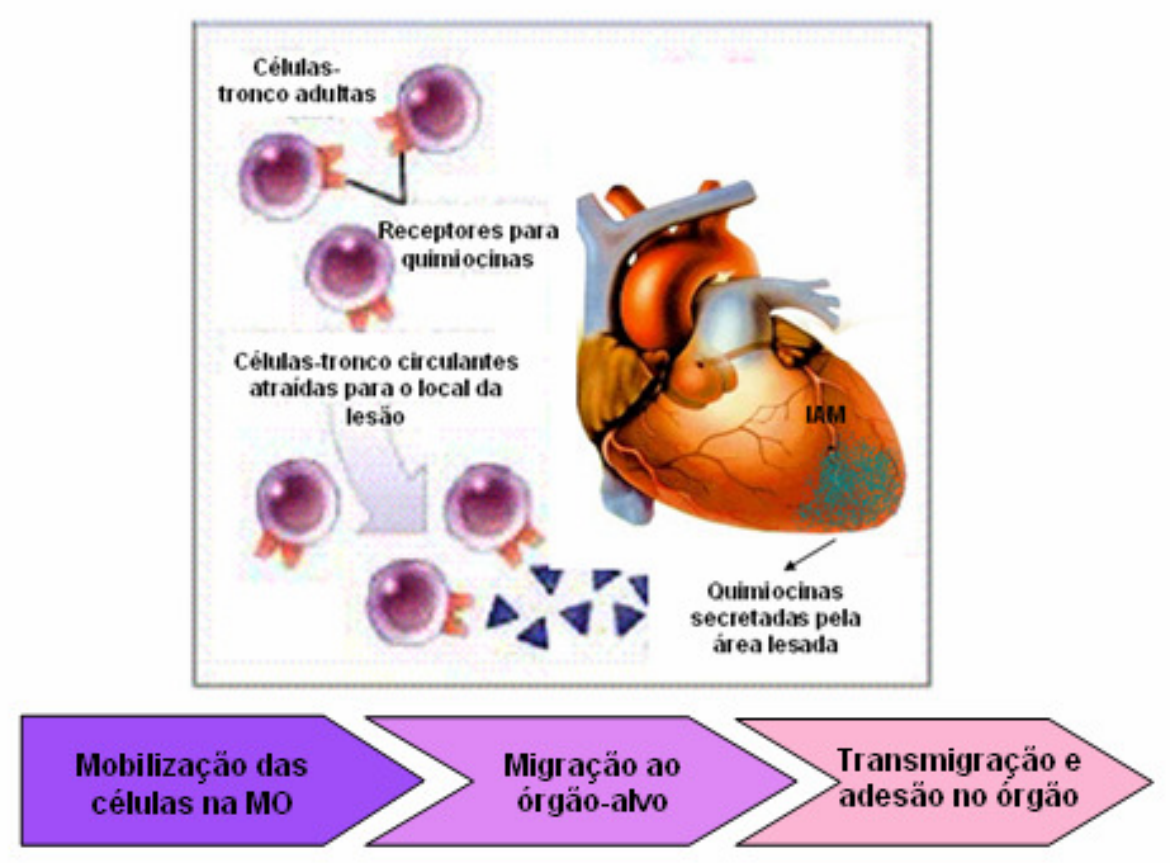

Figura 1. Homing de células-tronco hematopoiéticas para o coração durante o infarto do miocárdio. As principais etapas desse processo envolvem a mobilização de células-tronco da medula óssea seguida da migração dessas células através do sistema circulatório sanguíneo e a adesão no miocárdio sob sinalização quimioatrativa do miocárdio isquêmico.

As células-tronco, para permanecerem na medula óssea, precisam reconhecer sinais específicos. Existe um fator-chave que regula a permanência dessas células na medula óssea, o SDF-1. O SDF-1 é expresso por células do estroma da medula óssea como as células mesenquimais e os osteoblastos ${ }^{21}$. Por outro lado, as células-tronco hematopoiéticas expressam o receptor para o SDF-1, uma molécula conhecida como

CXCR4. A interação de SFD-1 com CXCR4 garante a estadia dessas células no compartimento medular. 
As células-tronco hematopoiéticas com CXCR4 na superfície da membrana, respondem ao gradiente de SDF-1 e sua localização preferencial na medula óssea pode ser explicada pelo fato de que em condições normais, esse é o órgão adulto que contém os níveis mais elevados de SDF-1, dado que a demanda de renovação celular é constante.

A concentração de SDF-1 não é o único fator que garante a estadia das célulastronco hematopoiéticas. As células estromais da medula óssea também expressam moléculas de adesão como o VCAM que intermedeiam a ancoragem das células-tronco 21.

Considerando a importância do eixo SDF-1 - CXCR4 como mecanismo fundamental para a permanência das células-tronco hematopoiéticas em um órgão, a expressão de SDF-1 por órgãos lesados como já bem descrito para o coração após isquemia, desempenharia um papel preponderante no homing dessas células para o coração, visando à regeneração tecidual. Ao incrementar localmente a concentração de SDF-1, as células migrariam na direção do fator, portanto, chegariam ao coração.

Porém a complexidade desse processo vai além de um simples sinal de gradiente de concentração de um único fator. Outros sinais, orquestrados temporalmente com a migração do gradiente de concentração de SDF-1 são necessários para a saída das células-tronco hematopoiéticas da medula óssea. Destaca-se aqui a importância das 
metaloproteinases (MMP-1, MMP-9) e outras proteases secretadas principalmente por neutrófilos sob o controle de G-CSF e GM-CSF. Novamente a participação de células e moléculas envolvidas com a inflamação pós-isquêmica tem um papel importante. O fato é que, a elevação no nível local cardíaco de SDF-1 necessita ser concomitante ao decréscimo dessa proteína na medula óssea. Isso pode acontecer em decorrência da destruição do SDF-1 e das moléculas de adesão nas células estromais da medula óssea pelas proteases, principalmente a metaloproteinase 9 (MMP-9). Ainda assim, os níveis de SDF-1 na medula dificilmente não são superados, mas a diminuição sinaliza a saída das células desse local.

Contudo, uma vez liberadas da medula óssea e ao transmigrarem através da interação com moléculas expressas por células endoteliais dos vasos sanguíneos locais, as células-tronco hematopoiéticas ganham a corrente sanguínea e seguem em direção ao órgão isquêmico, guiadas principalmente pelo gradiente de concentração de SDF-1.

O tráfego dessas células em direção ao gradiente de SDF-1 via circulação sanguínea é uma outra etapa do processo de recrutamento de células-tronco hematopoiéticas que é garantido pela permanência do sinal de homing via moléculas expressas pelos cardiomiócitos isquêmicos em níveis suficientemente elevados e duradouros. Uma das hipóteses que pode estar envolvida na deficiência de regeneração cardíaca após um trauma, é a ineficiência do coração em manter níveis elevados e duradouros de moléculas sinalizadoras do homing de células-tronco. De fato, como relação aos níveis de SDF-1, esses são encontrados apenas nas primeiras horas após o 
infarto do miocárdio, estando praticamente ausentes no sétimo dia após o evento isquêmico ${ }^{34}$.

A etapa de transmigração das células-tronco hematopoiéticas ao sistema sanguíneo coronariano, assim como para os neutrófilos durante o processo inflamatório, é mediada por moléculas de adesão em células endoteliais da microvasculatura cardíaca. A interação das células endoteliais com as células-tronco assegura que essas últimas possam adentrar ao hostil microambiente cardíaco acometido pela isquemia.

É de particular importância ressaltar que a sinalização para o recrutamento de células-tronco é concomitante aos eventos moleculares e celulares que provêem a resposta inflamatória durante a isquemia cardíaca. Nesse sentido, a presença de neutrófilos, interleucinas pró-inflamatórias, macrófagos e a presença de espécies reativas de oxigênio geradas pelo desequilíbrio redox, são potenciais fatores contra a permanência das células-tronco nesse local. Nesse contexto de intensa resposta inflamatória à qual as células-tronco estão expostas, a chance de sobrevida dessas células tende a diminuir.

Finalmente, a adesão das células-tronco no tecido cardíaco é a etapa que precede os prováveis mecanismos de reparo mediados por essas células. A expressão de moléculas de adesão pelos cardiomiócitos e também pelas células-tronco assegura a interação entre ambas. 
Em resumo, a participação de células-tronco no processo de reparo cardíaco depende de sinais seqüenciais envolvendo os órgãos em questão e também da capacidade que as células envolvidas nesse processo têm de responderem a esses sinais. Cada uma das etapas é fundamental para a efetividade do processo. O conhecimento acerca da repopulação de medula óssea tem contribuído significativamente para a elucidação dos processos envolvendo a regeneração celular/tecidual de órgãos adultos.

\subsection{Matrizes de Biopolímeros na Medicina Regenerativa}

Uma das razões que pode explicar a perda massiva de células durante o transplante é o veículo de administração dessas células. Em geral, as células-tronco são injetadas em solução aquosa de meio de cultura, solução fisiológica salina e até mesmo em soro fetal utilizado como fonte de fatores de crescimento para o cultivo das células. Essas soluções permitem que as células possam ser facilmente lavadas, especialmente nos casos onde elas atingem diretamente o sistema circulatório.

A utilização de biomatrizes injetáveis, não apenas poderia resolver esse problema, dado que as células permaneceriam retidas, como também, considerando o fato de que essas matrizes representariam uma estrutura pró-angiogênica apta para manter as células transplantadas, otimizaria a patência das células enxertadas ${ }^{51}$. 
A fibrina é um biomaterial amplamente empregado como selante cirúrgico. Não é tóxico e é biocompatível, não induz resposta inflamatória, portanto, não promove a extensão da fibrose cardíaca ${ }^{48}$. O uso isolado de matriz de fibrina demonstrou efeito positivo sobre a função cardíaca, prevenindo o remodelamento negativo ventricular em ratos submetidos à lesão de isquemia/reperfusão cardíaca ${ }^{49}$.

Evidências recentes sugerem que a combinação de células com biopolímeros injetáveis como a fibrina, colágeno e matrigel podem favorecer a sobrevida dessas células, a angiogênese e melhorar a função cardíaca em modelo animal de infarto agudo do miocárdio ${ }^{49-51}$. Nesse sentido, o emprego de células-tronco associado ao uso de biopolímeros é uma promissora proposta para a efetivação da engenharia de tecidos cardíaca. 
OBJETIVO

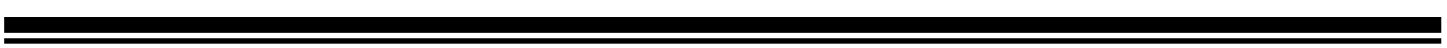


Considerando o curso temporal dos fatores relacionados aos mecanismos de mobilização, homing e retenção de células-tronco no contexto da isquemia cardíaca, bem como a provável relação entre esses mecanismos e a via de administração empregada para o transplante dessas células, o objetivo desse estudo foi investigar a retenção de células da medula óssea no coração de ratos submetidos à lesão por isquemia/reperfusão, de acordo com tempo após a isquemia para o transplante e a via de administração das células. Também buscamos investigar a relação entre a retenção de células e a função cardíaca dos animais.

Especificamente:

- Avaliar a retenção cardíaca de células da medula óssea transplantadas em ratos submetidos ao infarto agudo do miocárdio de acordo com:

I. a via de administração das células [intravenosa (IV), intracavitária - VE (IC), intracoronariana (ICO) ou intramuscular (IM)];

II. o momento após a isquemia para o transplante das células $(1,2,3$ ou 7 dias);

- Avaliar a biodistribuição das células da medula óssea transplantadas;

- Avaliar o efeito do uso de biopolímero de fibrina como veículo para o transplante das células da medula óssea sobre a retenção cardíaca dessas células; 
- Avaliar os efeitos da administração sistêmica e direta de CMO (com e sem fibrina associada) em ratos infartados sobre parâmetros histopatológicos do infarto e funcionais, de desempenho cardíaco dos animais. 
MÉTODOS

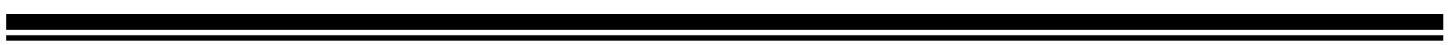




\subsection{PROCEDIMENTOS CIRÚRGICOS EXPERIMENTAIS}

\subsubsection{Modelo Animal de Isquemia Cardíaca}

Os procedimentos experimentais foram desenvolvidos em concordância com o guia institucional de cuidados e uso de animais de laboratório, com aprovação do Comitê de Ética em Pesquisa e Experimentação Animal (SDC/InCor - CAPEPESQ) do Hospital das Clínicas da Faculdade de Medicina da Universidade de São Paulo, Brasil (\#527/04; 0118/08).

Ratos machos Lewis isogênicos com 10 semanas de idade foram mantidos em caixas (5 animais/caixa) com livre acesso à água e comida sob ciclo claro-escuro de doze horas. Os animais foram anestesiados com uma combinação de ketamina (50 mg/kg peso corpóreo; Parke-Davis, Ann Arbor, MI, USA) e xilazina (10 mg/kg, i.p.; Bayer, Newhaven, CT, USA), intubados através de colocação de cateter intra-traqueal para a ventilação a $2,5 \mathrm{~mL}, 65$ pulsos/minuto com ciclos de pressão controlados em equipamento de ventilação para roedores (HARVARD Apparatus, Modelo 683, Holliston, MA, USA) e submetidos à toracotomia lateral.

O coração foi exposto e a artéria coronária esquerda foi circundada por um fio de sutura de nylon $(5,0)$ a aproximadamente $1 \mathrm{~mm}$ da sua origem, gentilmente ocluída, através da amarradura do fio, por 45 minutos e então liberada, permitindo-se a reperfusão da área mantida por essa artéria. Esse procedimento produziu uma área 
claramente demarcada (cianótica e esbranquiçada), correspondente à distribuição da artéria coronária esquerda distal à oclusão. Todos os animais foram mantidos individualmente por um período de recuperação de vinte e quatro horas.

Para os estudos de função cardíaca, o procedimento de isquemia foi o de ligadura permanente da artéria coronária. Tal procedimento provoca uma lesão do tipo transmural (que se estende do epicárdio ao endocárdio) que gera comprometimento da função cardíaca.

Previamente à administração das células a presença de infarto foi examinada através de exame ecodopplercardiográfico com o propósito de selecionar apenas os animais infartados com tamanho de IAM entre $30-40 \%$ da parede do ventrículo esquerdo. Esse pré-requisito foi adotado com o propósito evitar vieses na avaliação do desempenho cardíaco.

\subsubsection{Vias de Administração das Células da Medula Óssea ( ${ }^{99 m}$ Tc-CMO)}

Vinte e quatro, quarenta e oito ou setenta e duas horas após a isquemia cardíaca, os animais foram submetidos a outro procedimento cirúrgico para o transplante de $6 \mathrm{x}$ $10^{6}$ CMO diluídas em $100 \mu \mathrm{L}$ de PBS, através de uma das seguintes vias de administração experimentais: intravenosa [(IV) - pela veia caudal], intracavitária [(IC) com a agulha dentro do ventrículo esquerdo, confirmado pelo retorno de sangue na seringa], intracoronariana [(ICO) - com a agulha dentro do ventrículo esquerdo e oclusão da artéria aorta por vinte segundos durante a injeção, com o objetivo de 
mimetizar a infusão intracoronariana], e intramiocárdica [(IM) - com a agulha posicionada no miocárdio do animal, injetando-se na área limítrofe entre o miocárdio sadio e o isquêmico, conhecida como zona de borda]. O tórax foi fechado, o pneumotórax removido e então, vinte e quatro horas após o transplante das células, os animais foram submetidos à eutanásia para a coleta de seus órgãos.

\subsection{RADIOMETRIA NUCLEAR}

\subsubsection{Avaliação da Radioatividade nos Órgãos Coletados dos Animais que Receberam Células da Medula Óssea Marcadas ( ${ }^{99 m}$ Tc-CMO)}

Vinte e quatro horas após o transplante das células, os animais foram submetidos à eutanásia e o coração, pulmões, fígado, baço, rins, fêmur e amostra de sangue (aproximadamente $3 \mathrm{~mL}$ ) foram retirados desses animais e pesados. A radioatividade dos órgãos isolados foi medida em um contador de radiação gama (Automatic Gamma Counter 1480 - Perkin Elmer). Os valores de radioatividade no sangue e ossos foram estimados a partir da quantidade de radioatividade nas amostras desses tecidos, considerando-as como $7 \%$ e $10 \%$, respectivamente, do peso corpóreo do animal ${ }^{53}$. Os resultados foram expressos como a percentagem do total da radioatividade injetada após correção do decaimento da radioatividade. 


\subsubsection{Captação de Metabólitos do Marcado ${ }^{99 \mathrm{~m}}$ Tc-CMO no Coração}

Com o objetivo de avaliar a retenção cardíaca de metabólitos de $\left[{ }^{99 \mathrm{~m}} \mathrm{Tc}\right]$ tecnécio extruídos das CMO, $30 \times 10^{6}$ células foram incubadas em $500 \mu \mathrm{L}$ de meio de cultura por 24 horas. A suspensão de células foi então centrifugada e $100 \mu \mathrm{L}$ do sobrenadante foram injetados no miocárdio de cinco animais, vinte e quatro horas depois do infarto. Após outras vinte e quatro horas, os animais foram submetidos à eutanásia e seus corações foram coletados para a determinação da radioatividade nos mesmos.

\subsection{CULTURA DE CÉLULAS E ENSAIOS IN VITRO}

\subsubsection{Isolamento das Células da Medula Óssea e Radiomarcação}

Sob condições estéreis, os fêmures e tíbias de ratos machos Lewis de dez semanas de idade foram retirados e o tecido conectivo foi removido. A medula óssea foi extraída dos ossos através da lavagem de suas cavidades com meio de cultura DMEM (Dulbecco’s Modified Eagle's Médium). A suspensão resultante foi cuidadosamente homogeneizada para a dissolução da medula.

As células vermelhas foram removidas através de gradiente de densidade por meio de centrifugação a $829 \mathrm{~g}$ por 30 minutos após a adição do mesmo volume de solução de Ficoll-PaqueTM Plus (Amersham Bio Sciences AB, Uppsala, Sweden) à solução contendo as células da medula óssea. Após a centrifugação, a fração celular de 
baixa densidade, composta pelas assim denominadas, células da medula óssea nãofracionadas (CMO), foram coletadas e diluídas em solução salina PBS.

O radiofármaco ${ }^{99 \mathrm{~m}} \mathrm{Tc}-\mathrm{HMPAO}$ foi obtido pela reconstituição do kit liofilizado Ceretec ${ }^{\circledR}$ (Amersham) com $2 \mathrm{~mL}$ de solução de $\mathrm{NaCl}$ 0,9 \% contendo $1.48 \mathrm{GBq}$ (40 mCi) de pertecnetato de sódio (IPEN-CNEN, Brasil). A pureza radioquímica do produto marcado ( ${ }^{99 \mathrm{~m}} \mathrm{Tc}$-HMPAO) foi determinada através do procedimento de extração em acetato de etila. As CMO foram marcadas com ${ }^{99 \mathrm{~m}}$ Tc-HMPAO, com mudanças mínimas no protocolo padrão para marcação de leucócitos ${ }^{52}$.

Brevemente, a suspensão de CMO foi centrifugada, o sobrenadante removido e o pellet foi ressuspendido em $1 \mathrm{~mL}$ de solução contendo ${ }^{99 \mathrm{~m}} \mathrm{Tc}-\mathrm{HMPAO}$ e incubado por 15 minutos a $37^{\circ} \mathrm{C}$. Plasma, obtido a partir da centrifugação do sangue total dos mesmos animais doadores de medula, foi adicionado para interromper a marcação das células e finalmente a suspensão de CMO foi centrifugada a $466 \mathrm{~g}$ por 10 minutos. Então, o sobrenadante foi descartado e o pellet de CMO marcadas foi ressuspendido em PBS (phosphate-buffered saline). A centrifugação foi repetida para a eliminação completa de radiofármaco livre das células. A eficiência de marcação foi avaliada e calculada como a razão entre a atividade contida nas ${ }^{99} \mathrm{~m}$ Tc-CMO e o total de radioatividade (radioatividade nas células mais àquela do sobrenadante descartado).

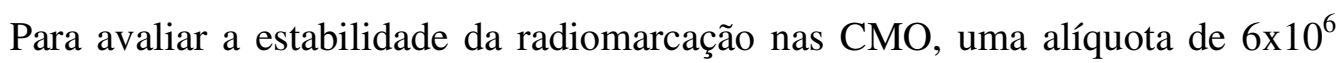
células marcadas foi incubada por 24 horas e então centrifugada. A radioatividade foi 
medida no pellet e no sobrenadante e a taxa de extrusão foi calculada como a eficiência de marcação. Para examinar o (s) potencial (is) efeito (s) nocivo da radiação e/ou dos componentes químicos do ${ }^{99 \mathrm{~m}} \mathrm{Tc}-\mathrm{HMPAO}$, a viabilidade das CMO foi determinada através do teste de exclusão de morte por azul de tripan.

\subsubsection{Avaliação da apoptose em ${ }^{99}$ Tc-CMO}

Um dos métodos utilizados para detecção precoce da apoptose é a avaliação da mudança na posição de fosfatidilserina (FS) na membrana celular. A FS exposta ao ambiente extracelular pode ser detectada através da ligação de anexina $\mathrm{V}$, uma proteína com alta afinidade por FS.

A morte celular por apoptose e necrose foi avaliada em células da medula óssea marcadas radioativamente. Brevemente, quatro horas após a marcação com ${ }^{99 \mathrm{~m}} \mathrm{Tc}-$ HMPAO, as CMO foram lavadas em PBS e centrifugadas (1200 rpm durante 5 minutos). O pellet de células foi fracionado em alíquotas de $0,5 \times 10^{6}$ células e essas alíquotas foram ressuspendidas em $200 \mu \mathrm{L}$ de uma solução tamponada (1X binding buffer - BD Bioscience ${ }^{\circledR}$ ). Posteriormente, $5 \mu \mathrm{L}$ de anexina V - FITC (BD Bioscience (B) e $10 \mu \mathrm{L}$ de iodeto de propídeo - PE (phycoeritrin), um corante fluorescente vital (BD Bioscience $($ )), foram adicionados às alíquotas e incubados por 15 minutos em temperatura ambiente protegidos da luz. Imediatamente após a marcação, as ${ }^{99 \mathrm{~m}} \mathrm{Tc}$ CMO foram avaliadas por citometria de fluxo (FACSCAlibur - BD ®) com o propósito de quantificar as células apoptóticas e necróticas da população estudada. 


\subsubsection{Extração e Cultura Primária de Células-Tronco Derivadas do Tecido Adiposo}

Células-tronco mesenquimais obtidas do tecido adiposo foram transplantadas em associação com fibrina em ratos e avaliadas histologicamente após 30 dias, sobretudo para verificar a eficácia da retenção das células com fibrina em longo prazo.

Ratos Lewis, machos, foram utilizados como doadores de células-tronco derivadas do tecido adiposo (CTTA). Os animais foram mortos por "overdose" intraperitoneal de pentobarbital sódico $(80 \mathrm{mg} / \mathrm{kg}$ ). Após tricotomia dos membros inferiores, foi realizada uma incisão para a remoção do tecido. $\mathrm{O}$ tecido adiposo inguinal branco removido foi copiosamente lavado com PBS. Em seguida o tecido foi digerido mecânica e enzimaticamente a $37{ }^{\circ} \mathrm{C}$ por 40 minutos, sob agitação constante, numa solução contendo colagenase tipo 1A a 0,075 \% (C-2674; Sigma®; St. Louis, MO), DMEM L e $20 \mathrm{mg} / \mathrm{g}$ de tecido de albumina bovina (BSA, Sigma). A atividade enzimática foi interrompida com $10 \mathrm{~mL}$ de FBS. O tecido adiposo digerido foi centrifugado a $466 \mathrm{~g}$ por 15 minutos e o pellet obtido foi ressuspendido em meio de cultura DMEM L enriquecido com $10 \%$ de FBS e $1 \%$ P/S [penicilina G (100 U/mL) e estreptomicina $(100 \mu \mathrm{g} / \mathrm{mL})]$. As células mantidas em atmosfera úmida contendo $5 \%$ de $\mathrm{CO}_{2}$ a $37^{\circ} \mathrm{C}$ por duas horas e em seguida, todo meio contendo células não-aderentes foi descartado. Foi adicionado um novo meio de cultura com as mesmas concentrações de FBS e P/S. As células-tronco obtidas foram mantidas por 3 dias em placas e então descoladas com solução de tripsina $(0,25 \%$ tripsina em 1 mM EDTA), contadas através 
do método de exclusão de morte por azul de trypan e plaqueadas em garrafas de cultura de $75 \mathrm{~cm}^{2}$ na densidade de $1 \times 10^{4}$ células $/ \mathrm{cm}^{2}$. O meio de cultura foi trocado a cada 3 dias. As células-tronco do tecido adiposo foram utilizadas para o transplante na terceira passagem. Anteriormente ao transplante, as CTTA foram marcadas com CM-DiI (C7000, Molecular Probes Inc., Oregon, U.S.A). Secções histológicas obtidas dos corações foram incubadas com DAPI (Sigma) para a identificação dos núcleos celulares.

\subsubsection{Extração e Cultura Primária de Fibroblastos Cardíacos}

Fibroblastos cardíacos foram extraídos e posteriormente modificados geneticamente para expressar continuamente a enzima beta galactosidase. Essas células foram utilizadas por serem eficientemente infectáveis com vetores adenovirais e, sobretudo, por funcionarem como ótimos vetores de expressão de transgene. Neste sentido, a identificação e localização dos fibroblastos transplantados com fibrina poderiam corroborar os dados quantitativos obtidos com a radiomarcação das células da medula óssea transplantadas com o mesmo veículo.

Para a extração de fibroblastos cardíacos foram utilizados de 2 a 3 ratos adultos Lewis submetidos à eutanásia em câmara de $\mathrm{CO}_{2}$. Após constatação da parada cardíaca, os animais foram posicionados em decúbito dorsal e uma incisão cutânea transversal foi feita estendendo-se por todo tórax do animal; o coração foi retirado e transferido para um tubo plástico contendo solução gelada de PBS. Os corações foram transferidos para 
placa de petri em fluxo laminar e secionados. O tecido seccionado foi transferido para tubo plástico contendo solução de colagenase tipo 2 (200 U/mL, Sigma Chemical Co., Milwaukee, WI, USA) e mantido sob agitação a $37^{\circ} \mathrm{C}$ por períodos de 30 minutos ou até completa dissociação do tecido cardíaco. Após cada período de incubação o sobrenadante foi recuperado e acrescido de $1 \mathrm{~mL}$ de FBS. Esta suspensão de células foi submetida à centrifugação a 150 g por 5 minutos em temperatura ambiente. O precipitado obtido de cada etapa foi ressuspendido em DMEM acrescido de $15 \%$ de FBS (vol./vol.) e $1 \%$ (vol./vol.) de penicilina/estreptomicina (1000 UI/mL-1000 Ag/mL; GIBCO BRL, Gaithersburg). Posteriormente foi transferido para garrafa de 75 $\mathrm{cm}^{2}$ mantida em atmosfera úmida contendo $5 \%$ de $\mathrm{CO}_{2}$ a $37^{\circ} \mathrm{C}$. Após 24 horas, o meio de cultura foi substituído por DMEM suplementado com $20 \%$ de FBS. Os fibroblastos foram utilizados para o transplante na terceira passagem.

\subsubsection{Transdução de Fibroblastos Cardíacos com Vetor Adenoviral Contendo a Proteína Beta - Galactosidase - AdRSVLacZ}

Fibroblastos cardíacos mantidos em cultura, em garrafas de $75 \mathrm{~cm}^{2}$, sob confluência de 80 a $90 \%$ foram infectados com solução estoque de adenovírus recombinante para o gene Lac Z [(beta - galactosidase, $\beta$-gal) (AdRSVLacZ)]. O procedimento de infecção celular foi realizado a partir da substituição do meio de cultura de miofibroblastos cardíacos por $3 \mathrm{~mL}$ de solução estoque de vírus (DMEM + partículas) e mantidos por 12 horas em atmosfera úmida contendo $5 \%$ de $\mathrm{CO}_{2}$ a $37^{\circ} \mathrm{C}$. 


\subsubsection{Polímero de Fibrina}

O polímero de fibrina foi preparado com a combinação de fibrinogênio e trombina no momento da injeção. O fibrinogênio foi obtido por separação do plasma a partir de $50 \mathrm{~mL}$ de sangue de ratos da mesma linhagem com adição de $5 \mathrm{~mL}$ de citrato de sódio 3,8\%. Finalmente o fibrinogênio foi isolado utilizando-se a técnica de crioprecipitação ${ }^{48}$ e diluído na concentração final de $316 \mathrm{mg} / \mathrm{dL}$. Trombina humana (Baxter Healthcare, Inc.) foi utilizada para catalisar a reação de polimerização da fibrina.

As células foram ressuspendidas em $80 \mu \mathrm{L}$ da solução de fibrinogênio e, alguns segundos antes da injeção no tecido, $20 \mu \mathrm{L}$ de trombina $(250 \mathrm{UI} / \mathrm{mL})$ foram adicionados à seringa contendo a suspensão celular. Esta combinação permitiu uma janela adequada de tempo de vinte segundos para a realização da injeção miocárdica antes da polimerização.

\subsection{AVALIAÇÃO HISTOLÓGICA}

\subsubsection{Medidas - Infarto do Miocárdio, Espessura da Cicatriz de Colágeno e Perímetro da Cavidade do Ventrículo Esquerdo}

Ao final da sessão experimental, os animais foram anestesiados com injeção intraperitoneal letal de pentobarbital sódico $(80 \mathrm{mg} / \mathrm{kg})$ e o coração perfundido para a 
preparação histológica. Brevemente, cada animal foi posicionado em decúbito dorsal e uma incisão cutânea transversal foi feita estendendo-se do abdome ao tórax do animal. O coração foi exposto e o animal foi perfundido sob pressão constante de 80 - $90 \mathrm{~mm} \mathrm{Hg}$ com solução fisiológica contendo $\mathrm{KCl}(14 \mathrm{mM})$. Após a constatação da parada cardíaca, a solução fisiológica foi substituída por uma solução de formol tamponado a $4 \%$. O coração foi retirado e mantido por vinte e quatro horas em formol tamponado. Após fixação, o coração foi removido e mantido em formaldeído $37 \%$ por 24 horas. Os corações foram então segmentados através de cortes transversais de maneira que foram obtidas três partes: basal, mediana e apical. Foram utilizados apenas os segmentos mediano e apical, pois esses continham a região infartada. Procedeu-se então a rotina histológica de processamento do material em aparelho autotécnico com ciclo total de doze horas para a desidratação, diafanização e parafinização do material. Em seguida os corações foram incluídos em blocos de parafina e cortados em micrótomo, gerando cortes de $5 \mu \mathrm{m}$ de espessura que foram dispostos em lâminas. As lâminas contendo os cortes foram mantidas por vinte e quatro horas em estufa a $75^{\circ} \mathrm{C}$ para a remoção completa da parafina. Essas lâminas foram submetidas à coloração de "picrossirius red", uma coloração para o colágeno total do tecido, de acordo com o protocolo utilizado em nosso laboratório. Resumidamente, as lâminas obtidas foram imersas na coloração de "picrossirius" por uma hora e trinta minutos. Posteriormente foram lavadas três vezes em água corrente e então imersas e mantidas em água por 10min. Em seguida foram desidratadas através de imersão em banhos de xilol consecutivos e preparadas para análise em meio de montagem permanente. As lâminas foram fotografadas e as imagens adquiridas com o auxílio do programa NIS - Elements AR 2.30, através de câmera 
Nikon Hg 100W - LH-M100CB-1 acoplada em uma lupa Nikon SMZ800 em aumento de duas vezes. Foi utilizado o software UTHSCSA ImageToll® para a realização das medidas. O tamanho da lesão foi determinado através da percentagem da circunferência média do ventrículo esquerdo acometida pela cicatriz de colágeno, marcada em vermelho pelo "picrossirius red". Os valores gerados em pixels foram convertidos em milímetros de acordo com a orientação do programa.

\subsubsection{Identificação das Células Injetadas no Coração}

Para a avaliação histológica dos corações dos animais que foram transplantados com células-tronco derivadas do tecido adiposo marcadas com CM-DiL os animais foram sacrificados e o coração perfundido segundo o procedimento já descrito. Os corações dos animais transplantados com fibroblastos cardíaco expressando a enzima $\beta$ gal foram removidos e imediatamente congelados em nitrogênio líquido para preservar a atividade da beta galactosidase. As secções histológicas dos corações dos animais transplantados com fibroblastos cardíacos foram obtidas através de cortes feitos em criostato $(5 \mu \mathrm{m})$ e dispostas em lâminas para a realização do ensaio para a verificação da atividade da beta galactosidase.

Para os animais transplantados com células-tronco mesenquimais do tecido adiposo, foi realizada a rotina de perfusão e fixação do coração conforme descrito acima. As lâminas foram observadas em microscópio de fluorescência (Nikon Eclipse E600) para a visualização das células-tronco do tecido adiposo marcadas. 


\subsubsection{Ensaio Macrométrico para a Beta - Galactosidase}

Para identificar a expressão de beta galactosidase nos fibroblastos cardíacos implantados nos corações de ratos, foi realizado o ensaio enzimático para a ß-gal.

Cortes de $5 \mu \mathrm{m}$ do coração dos ratos implantados com fibroblastos infectados com o transgene para a enzima beta galactosidase foram dispostos em lâminas e fixados em formaldeído $2 \%$ e glutaraldeído $0.2 \%$ por 10 minutos. Após esse período as lâminas foram lavadas por duas vezes em PBS e coradas overnight com uma solução contendo $0,1 \%$ de $\mathrm{x}$-gal, $5 \mathrm{mM}$ de $\mathrm{K}$ ferricianida, $2 \mathrm{mM}$ de $\mathrm{K}$ ferrocianida, $2 \mathrm{mM}$ de $\mathrm{MgCl}_{2}$ para um volume determinado de PBS. Essa técnica permite a visualização macroscópica em azul da região que contém a enzima em atividade.

\subsection{AVALIAÇÃO DA FUNÇÃO CARDÍACA}

\subsubsection{Exame Ecodopplercardiográfico}

Os animais dos diferentes grupos experimentais foram submetidos ao exame ecodopplercardiográfico imediatamente antes do implante das células e trinta dias após o evento isquêmico cardíaco. Para a realização do exame, foi utilizado o equipamento Acuson Sequóia 5600 (Ultrasoud system, Acusom). Foram realizadas medidas com o objetivo de se determinar a fração de ejeção do ventrículo esquerdo (VE), espessura da parede do VE, fração de encurtamento da parede do VE, determinação da área isquêmica entre outras. 


\subsubsection{Avaliação Hemodinâmica da Função Cardíaca}

Trinta dias após o infarto do miocárdio foi realizado estudo hemodinâmico com os animais aquecidos $\left( \pm 37^{\circ} \mathrm{C}\right)$, mantidos sob plano anestésico adequado com uretana (1,2g/kg, iv, Sigma, MO, USA), e ventilação mecânica (freqüência: 100 movimentos/minuto e volume corrente: $10 \mathrm{~mL} / \mathrm{kg})$ enriquecida com oxigênio $(0,6$ a 0,8 L/min). A veia femoral direita foi cateterizada para manutenção do plano anestésico, administração de fármacos e reposição hidrossalina. Um micromanômetro Millar (MikroTip® 2F, Millar Instruments Inc., Houston, TX, USA) teve sua extremidade distal posicionada dentro da cavidade ventricular esquerda a partir de cateterismo da carótida comum direita para medida da pressão intraventricular. Após toracotomia direita ( $3^{\circ}$ espaço intercostal), foi posicionado um sensor de fluxo (Transonic Flowprobe, Transonic Systems Inc. NY, USA) na aorta ascendente, devidamente conectado ao sistema de medida do fluxo (Small Animal Blood Flow Meter - T206, Transonic Systems Inc. NY, USA). Os dados de pressão intraventricular e fluxo aórtico obtidos pelo software AcqKnowledge ${ }^{\circledR}$ 3.7.5. (Biopac Systems Inc., CA, USA) possibilitaram computar os valores instantâneos de: pressões ventriculares sistólica (PSVE) e diastólica final (PDfVE em mm Hg), frequiência cardíaca (em batimentos por minuto, bpm), primeira derivada temporal de pressão positiva e negativa (dP/dt em mm $\mathrm{Hg} / \mathrm{s}$ ), débito cardíaco ( $\mathrm{DC}$, em $\mathrm{mL} / \mathrm{min}$ ) e volume sistólico ejetado (VSE, em $\mu \mathrm{L}$ ), além de calcular os valores indexados de ejeção pelo peso de cada animal - índice cardíaco e índice de volume sistólico ejetado (débito cardíaco e volume sistólico ejetado divididos 
pelo peso do animal em quilogramas, IC e IVSE, respectivamente) e índice do trabalho sistólico (ITS, em g.m/kg/batimento), dado pela fórmula:

$$
\mathrm{iTS}=(\mathrm{PSVE}-\mathrm{PDfVE}) .(\mathrm{iVSE}) .0,0136
$$

Avaliação hemodinâmica durante aumento súbito da pós-carga

A avaliação hemodinâmica dos grupos experimentais foi feita sob condições basais e durante estresse súbito da pós-carga, através de uma sobrecarga pressórica induzida pela injeção de fenilefrina $(25-75 \mu \mathrm{g} / \mathrm{kg}$, i.v. in bolus, Sigma, St. Louis, MO, USA), suficiente para elevar a pressão sistólica em 50 a $70 \%$ da basal. A análise posterior dos dados permitiu correlacionar as diferentes variáveis anteriormente mencionadas, possibilitando a avaliação da capacidade de ejeção cardíaca em condições basais e de sobrecarga pressórica. Esse procedimento já foi testado como capaz de identificar depressão do desempenho ventricular em ratos infartados, mesmo que os parâmetros hemodinâmicos apresentem-se normais ou muito próximos à normalidade quando avaliados sob condições basais.

\subsection{ANÁLISE ESTATÍSTICA}

As diferenças na radioatividade dos órgãos entre os grupos foram comparadas através da análise de variância de dois fatores (two-way ANOVA, seguido de pós-teste Tukey) para avaliar o efeito do tempo pós-infarto e da via de administração sobre a 
retenção cardíaca das células. Análise de variância de um fator (one-way ANOVA, seguido de pós-teste Tukey) foi utilizado para comparar a diferença na retenção de células entre 2 ou mais grupos e o teste $t$ foi utilizado para comparar valores de retenção entre dois grupos.

Os resultados foram expressos como média \pm erro padrão da média (EPM). Análise de regressão linear foi utilizada para avaliar o efeito da sobrecarga pressórica sobre a função cardíaca. Em todos os casos, a diferença foi considerada significativa quando o valor de $p$ foi menor ou igual a 0,05 . 
RESULTADOS

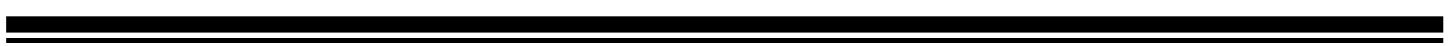




\subsection{EFICIÊNCIA, ESTABILIDADE E CITOTOXICIDADE DA RADIOMARCAÇÃO EM CÉLULAS DA MEDULA ÓSSEA}

A eficiência de marcação é entendida como a capacidade das células de incorporar o radiofármaco. Assume-se que todas as células apresentam um similar potencial de fazê-lo, o que resulta, em teoria, numa incorporação uniforme no sentido de que todas as células devem conter, pelo menos, uma molécula do composto. A eficiência de marcação é, então, resultado da capacidade de incorporação do conjunto de células, e isso determina a intensidade do sinal radioativo emitido por essas células a partir da quantidade de radiofármaco fornecido a elas. Assim, a eficiência de marcação funciona como controle da radiomarcação inclusive para orientar se a emissão radioativa das células pode ser captada.

Nesse estudo, as células da medula óssea (CMO) apresentaram uma eficiência de marcação média de $14,9 \pm 3,5 \%$, resultando em aproximadamente $1,98 \mathrm{MBq}$ por $10^{6}$ CMO. Entretanto, a radioatividade do ${ }^{99 \mathrm{~m}} \mathrm{Tc}$ detectada nas células e no sobrenadante revelou que apenas $33,0 \pm 2,5 \%$ da radioatividade inicialmente incorporada, permaneceram dentro das células após 24 horas da marcação (figura 2). 


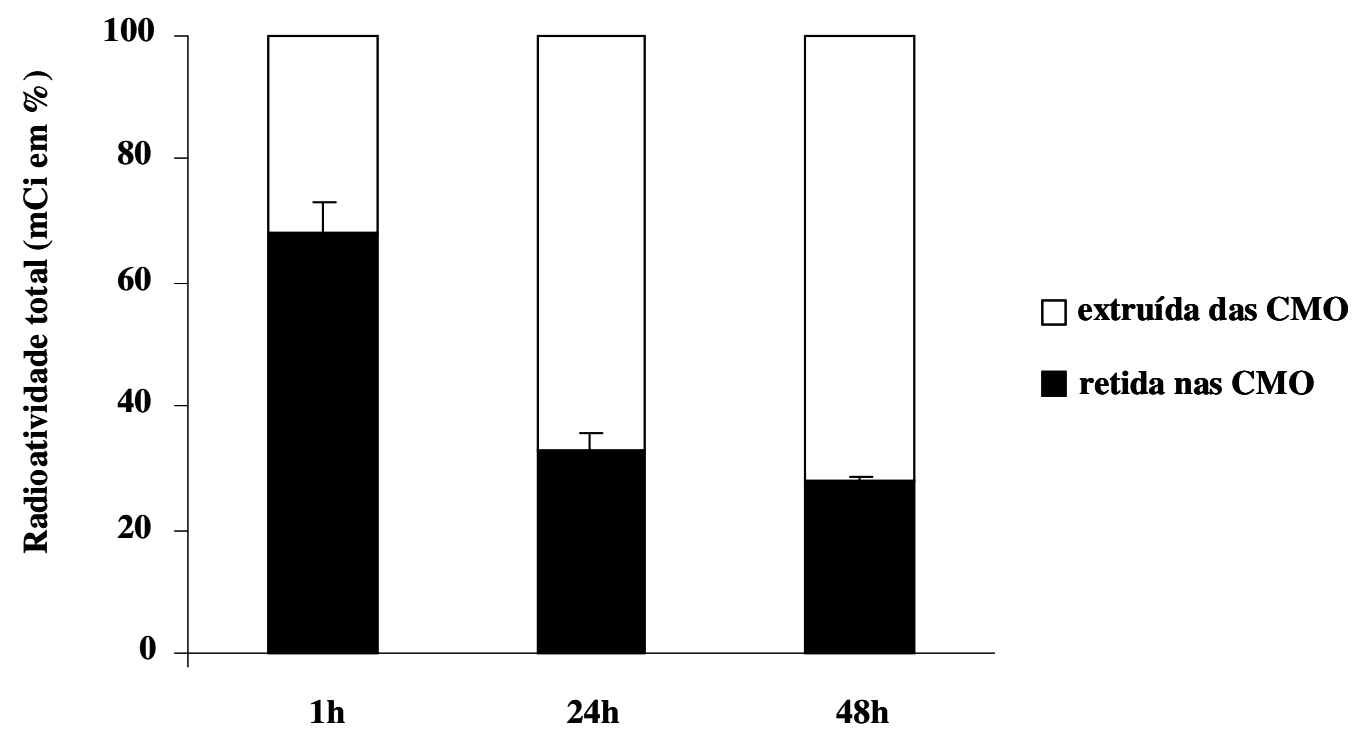

Tempo após marcação (h)

Figura 2. Cinética de extrusão do [ $\left.{ }^{99 \mathrm{~m}} \mathrm{Tc}\right]$ das células da medula óssea em diferentes momentos após a marcação. As barras negras representam a radioatividade retida nas $\mathrm{CMO}$ e as barras brancas a radioatividade liberada no sobrenadante por essas células.

A ausência de deterioração significativa da viabilidade celular (80 \% para CMO marcadas $\left[{ }^{99 \mathrm{~m}} \mathrm{Tc}-\mathrm{CMO}\right] v s .87,5 \%$ para as não-marcadas [CMO], $\left.p>0,05\right)$, como indicado pelo teste de exclusão de morte por azul de trypan, sugeriu que a radioatividade detectada no sobrenadante foi consequiência da extrusão do ${ }^{99 \mathrm{~m}} \mathrm{Tc}$ das CMO marcadas e não da morte das células. Adicionalmente, com a finalidade de investigar a possível capacidade do ${ }^{99 \mathrm{~m}} \mathrm{Tc}$ de induzir apoptose nas CMO, foi avaliada a externalização de fosfatidilserina, um fosfolipídeo da membrana citoplasmática cuja distribuição está 
restrita à porção interna da bicamada lipídica; a exposição desse fosfolipídeo é utilizada como marcador do início do processo de morte por apoptose. A análise da marcação com anexina V (anti-fosfatidilserina) e iodeto de propídeo (corante vital) não mostrou diferença entre as CMO não-marcadas e marcadas com relação à apoptose $(0,22 \pm$ $0,02 \%$ vs. $1,24 \pm 0,13 \%$, respectivamente) e à necrose ( $0,18 \pm 0,01 \%$ vs. $0,16 \pm 0,02 \%$, respectivamente).

Contudo, com o objetivo de determinar o acúmulo das células transplantadas, os valores da radioatividade no coração foram corrigidos de acordo com a taxa de extrusão de ${ }^{99 \mathrm{~m}} \mathrm{Tc}$ das CMO in vitro $(33,0 \%)$, assumindo uma equivalente taxa de extrusão in vivo.

\subsection{ACÚMULO CARDÍACO DE CÉLULAS DA MEDULA ÓSSEA}

\subsubsection{Efeito do Tempo após o Infarto}

Com o objetivo de determinar o momento mais apropriado, em termos de retenção, para a administração das células após o infarto, as ${ }^{99 \mathrm{~m}} \mathrm{Tc}-\mathrm{CMO}$ foram transplantadas através de 4 diferentes vias (IV, IC, ICO e IM) e em momentos distintos após o infarto agudo do miocárdio (1, 2, 3 ou 7 dias). Inesperadamente, a retenção cardíaca das CMO não diferiu entre os tempos testados para as vias IV, IC e ICO ( $p>$ 0,05). Por outro lado, na via intramiocárdica, a retenção cardíaca de CMO foi maior nos animais injetados 7 dias após o infarto, comparada às observadas nos animais nos quais as células foram adminstradas 1,2 ou 3 dias após a isquemia $(p<0,01)$. A tabela1 e a 
figura 3 a mostram a percentagem média da radioatividade nos corações dos animais que receberam ${ }^{99 \mathrm{~m}} \mathrm{Tc}-\mathrm{CMO}$ nos grupos experimentais avaliados. A figura $3 \mathrm{~b}$ mostra a retenção de ${ }^{99 \mathrm{~m}} \mathrm{Tc}-\mathrm{CMO}$ nos animais que receberam-nas por via intramiocárdica nos diferentes tempos pós-infarto testados.

\begin{tabular}{|c|c|c|c|c|c|c|c|c|c|}
\hline \multirow{2}{*}{ Via } & \multicolumn{2}{|r|}{ 1d } & \multicolumn{2}{|r|}{ 2d } & \multicolumn{2}{|r|}{ 3d } & \multicolumn{2}{|r|}{$7 d$} & \multirow{2}{*}{ Valor $p$} \\
\hline & $\mathbf{n}$ & $\%$ & $\mathbf{n}$ & $\%$ & $\mathbf{n}$ & $\%$ & n & $\%$ & \\
\hline IV & 4 & $0.14(0.02)$ & 7 & $0.22(0.05)$ & 4 & $0.13(0.02)$ & 5 & $0.04(0.00)$ & $>0.05$ \\
\hline IC & 4 & $0.43(0.02)$ & 4 & $0.49(0.12)$ & 4 & $0.71(0.27)$ & 5 & $0.18(0.11)$ & $>0.05$ \\
\hline ICO & 4 & $0.62(0.15)$ & 5 & $1.28(0.36)$ & 4 & $0.53(0.1)$ & 4 & $0.32(0.13)$ & $>0.05$ \\
\hline IM & 5 & $8.27(2.04)$ & 7 & $4.83(1.51)$ & 5 & $6.55(1.98)$ & 4 & $16.54(4.36)$ & $<0.01$ \\
\hline
\end{tabular}

Tabela 1. Retenção cardíaca de ${ }^{99 \mathrm{~m}}$ Tc-CMO injetadas 1,23 ou 7 dias após o infarto do miocárdio. As percentagens representam a média $( \pm \mathrm{EPM}) . n$ indica o número de animais em cada grupo. 


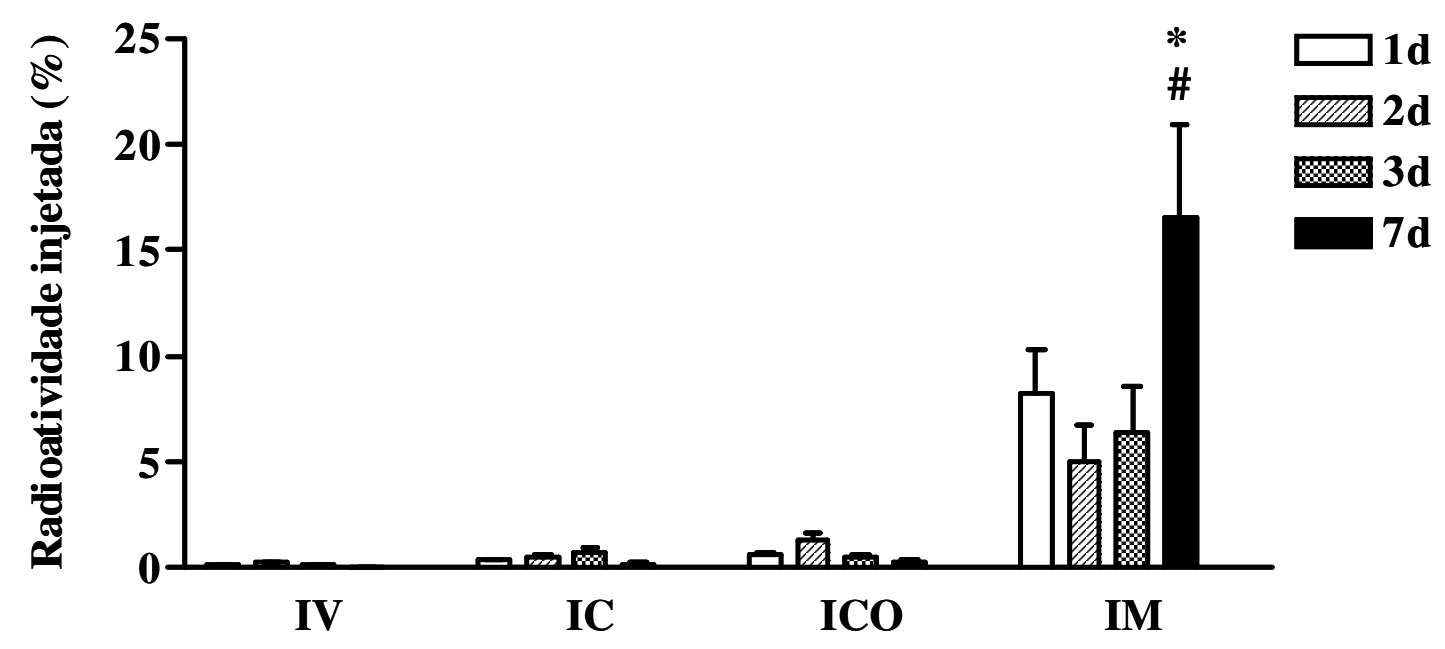

Figura 3a. Representação gráfica dos dados apresentados na tabela 1. A figura mostra a retenção cardíaca de ${ }^{99 m}$ Tc-CMO injetadas $1,2,3$ ou 7 dias após o infarto do miocárdio. IV, IC, ICO e IM indicam, respectivamente, as vias de administração de células intravenosa, intracavitária (VE), intracoronariana e intramiocárdica. Os valores estão expressos como a percentagem média da radioatividade injetada. * $(p<0,001)$ e \# $(p<0,01)$ indicam, respectivamente, diferença estatisticamente significativa entre os grupos IM 7d e IM 2d, 3d e IM 7d e IM $1 d$.

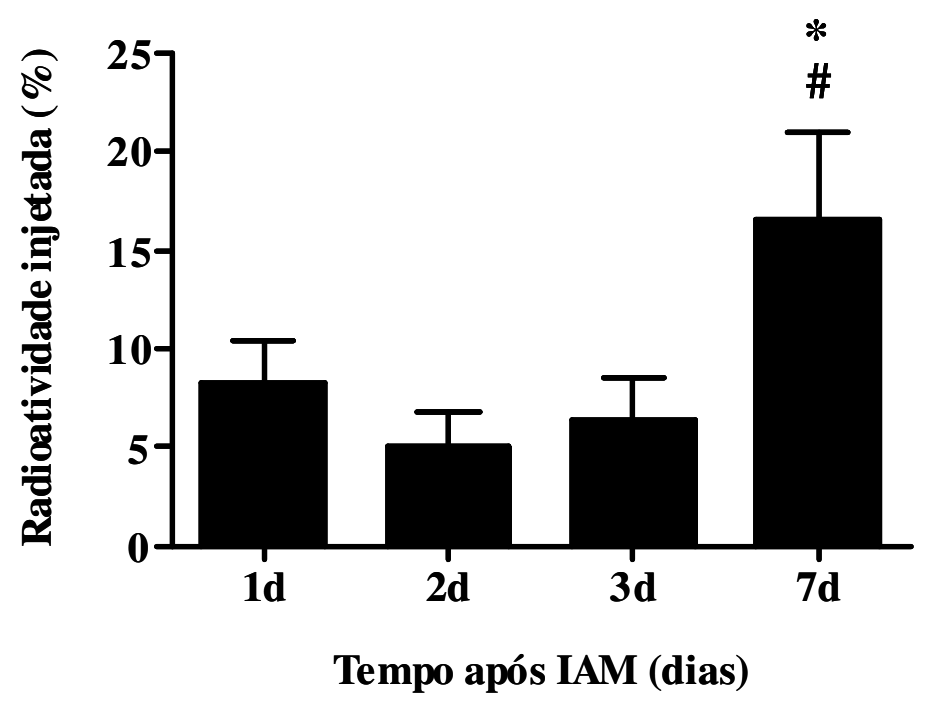

Figura 3b. Retenção cardíaca de ${ }^{99 \mathrm{~m}} \mathrm{Tc}-\mathrm{CMO}$ injetadas 1 , 2, 3 ou 7 dias após o infarto do miocárdio pela via intramiocárdica (IM). Os valores estão expressos como a percentagem média da radioatividade injetada. * ( $\mathrm{p}<$ $0,001)$ e \# $(\mathrm{p}<0,01)$ indicam, respectivamente, diferença estatisticamente significativa entre os grupos IM 7d e IM 2d, 3d e IM 7d e IM 1d. 
Finalmente, a análise estatística mostrou interação significativa entre os fatores (via e tempo), indicando que a variável "via" tem efeito extremamente significativo sobre os resultados observados $(p<0,0001)$.

\subsubsection{Efeito da Via de Administração das Células}

Considerando que a diferença na retenção cardíaca das $\mathrm{CMO}$ não foi estatisticamente significativa no intervalo de tempo testado para as vias IV, IC e ICO, os valores encontrados de radioatividade nos quatro tempos foram agrupados para cada uma dessas vias. Em outras palavras, o valor da retenção cardíaca das CMO para cada uma dessas vias resultou da média dos valores de todos os tempos testados em cada uma delas. Portanto, o número total de animais foi de 20 para a via IV, 17 para IC e 17 para ICO.

Apesar da diferença na retenção de CMO entre os tempos testados para a via intramiocárdica, todos os animais foram agrupados $(n=21)$, unicamente com o propósito de mostrar a variação na dimensão da retenção para cada uma das vias.

A despeito da via de administração, a radioatividade retida no coração 24 horas após a injeção das células foi bastante reduzida. Conforme os dados já apresentados, a injeção via IM foi a mais eficiente das vias testadas, exibindo um acúmulo de CMO significativamente maior que o atingido pelas vias IV, IC e ICO $[8,64 \pm 1,56 \%$ da radioatividade injetada $v s .0,14 \pm 0,02(p<0,001), 0,44 \pm 0,08(p<0,001)$ e $0,72 \pm 0,14$ $\%(p<0,001)$, respectivamente]. Figura 4. 


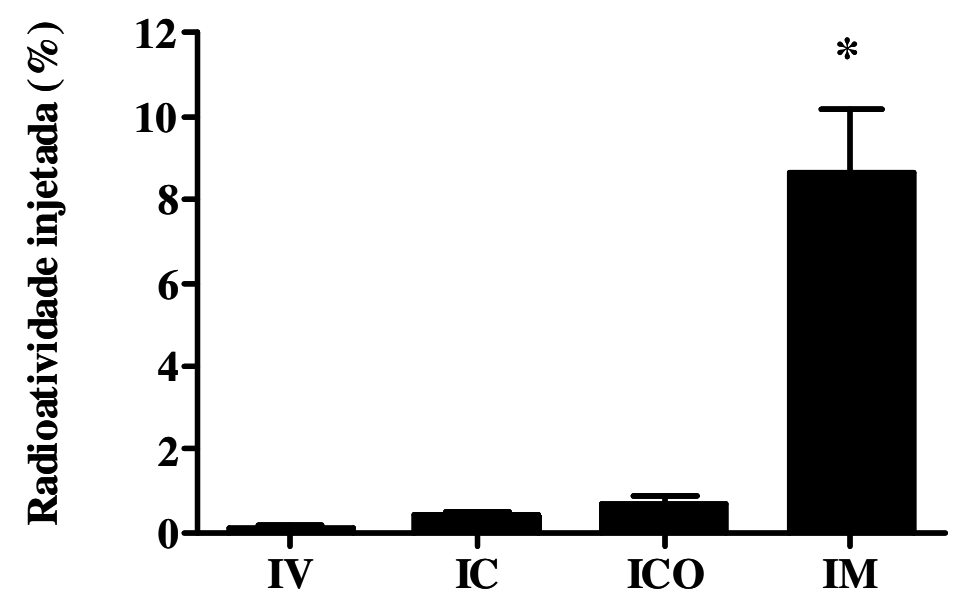

Figura 4. Acúmulo cardíaco de ${ }^{99 m}$ Tc-CMO administradas por diferentes vias. IV $(n=20)$, IC $(n=17)$, ICO $(n=17)$ e IM $(n=21)$ representam, respectivamente, as vias de administração intravenosa, intracavitária (VE), intracoronariana e intramiocárdica. * $(p<0,001)$ indica diferença estatisticamente significativa entre a via IM e as demais vias.

Para confirmar se a radioatividade no coração observada após a injeção IM era de fato representativa do acúmulo de CMO e não conseqüência da combinação de CMO com o $\left[{ }^{99 \mathrm{~m}} \mathrm{Tc}\right]$ tecnécio extruído remanescente no tecido cardíaco, CMO marcadas radioativamente foram incubadas por 24 horas e então o sobrenadante (contendo apenas o [ ${ }^{99 \mathrm{~m}} \mathrm{Tc}$ ] tecnécio extruído) foi injetado através da via IM. A radioatividade obtida 24 horas após a injeção dos corações injetados com CMO marcadas $\left({ }^{99 \mathrm{~m}} \mathrm{Tc}-\mathrm{CMO}\right)$ foi cerca de 13 vezes superior à radioatividade obtida dos corações em que apenas o sobrenadante contendo o tecnécio extruído foi injetado $(2,76 \pm 0,68 \%$ vs. $0,21 \pm 0,05 \% ; p=0,04)$ Esses dados sugerem que a contribuição do tecnécio livre $\left[{ }^{99 m} \mathrm{Tc}\right]$ para o total de radioatividade detectada no coração pode ser desconsiderada. 
Além disso, avaliamos a biodistribuição do [ $\left.{ }^{99 \mathrm{~m}} \mathrm{Tc}\right]$ tecnécio extruído nos animais que o receberam através da injeção intramiocárdica. Os dados sugerem que, ao ser eliminado do coração, o composto contendo $\left[{ }^{99 \mathrm{~m}} \mathrm{Tc}\right]$ tecnécio é provavelmente metabolizado no fígado e excretado pelos rins (figura 5). Esse dado corrobora a observação de que o [ ${ }^{99 \mathrm{~m}} \mathrm{Tc}$ ] tecnécio liberado pelas células não fica retido nos tecidos e é eliminado pelo organismo.

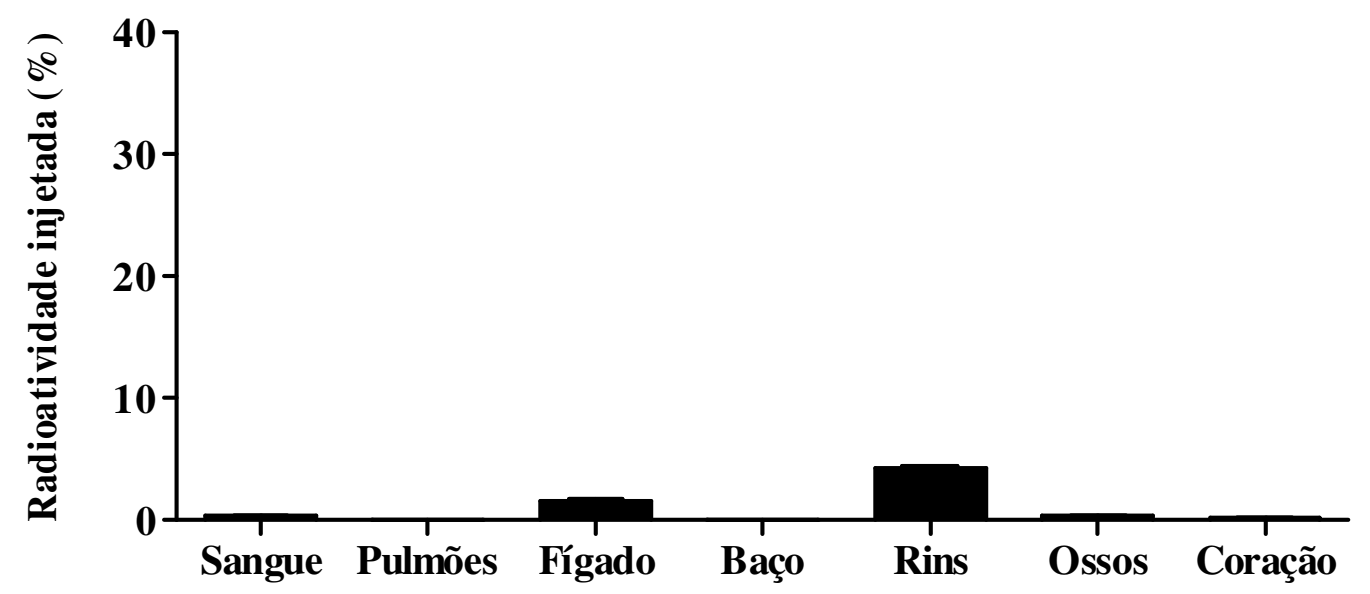

Figura 5. Biodistribuição do $\left[{ }^{99 \mathrm{~m}} \mathrm{Tc}\right]$ tecnécio extruído de CMO e injetado intramiocardicamente no coração de ratos submetidos à lesão cardíaca por isquemia.

O produto extruído das CMO também foi avaliado através de cromatografia com o objetivo de verificar se o composto químico liberado das células guardava as características do produto originalmente utilizado para a marcação das células.

$\mathrm{Na}$ análise cromatográfica da solução contendo o composto de $\left[{ }^{99 \mathrm{~m}} \mathrm{Tc}\right]$ tecnécio extruído das CMO marcadas, encontramos 26,9\% da espécie coloidal do tecnécio, 10,2 
$\%$ do tecnécio na forma de pertecnetato e $62,9 \%$ da radioatividade do tecnécio em uma forma química não determinada, mas que não correspondia ao ${ }^{99 \mathrm{~m}} \mathrm{Tc}-\mathrm{HMPAO}$. Nenhum desses compostos tem a capacidade de ligar-se novamente ao HMPAO, ou seja, a molécula responsável pela radiomarcação das CMO não é a mesma que àquelas encontradas na solução que continha o produto extruído dessas células. Nesse sentido, as chances de ter havido "marcação de novo" de outras células presentes no coração e, conseqüentemente vieses, são muito baixas e, portanto, desprezíveis.

\subsection{BIODISTRIBUIÇÃO DAS CÉLULAS DA MEDULA ÓSSEA}

A avaliação da radioatividade em outros órgãos mostrou que, 24 horas após a administração das CMO, o padrão de biodistribuição das CMO foi similar para todas as vias de administração testadas (figura 6) nos animais que receberam as células 1 a 3 dias após o infarto. Aproximadamente $50 \%$ da radioatividade injetada foi encontrada em outros órgãos. Valores de radioatividade elevados foram detectados em fígado, baço e rins com valores marcadamente menores em pulmões e ossos. 


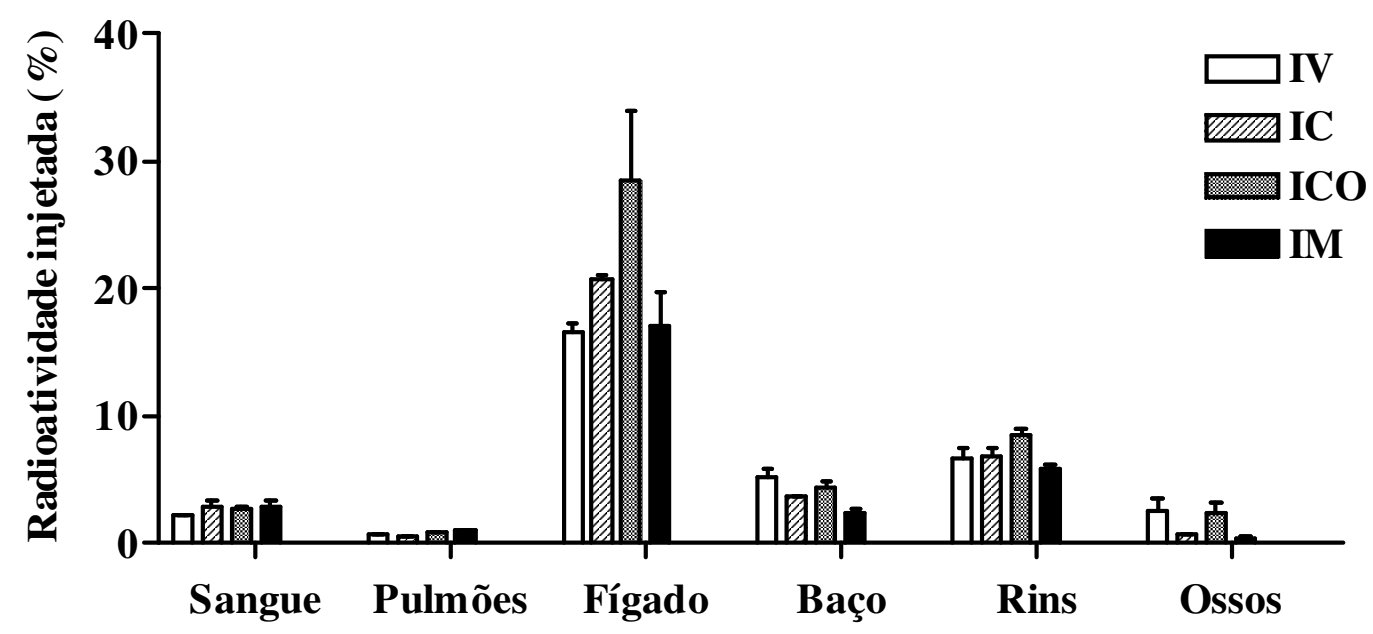

Figura 6. Biodistribuição das ${ }^{99 m}$ Tc-CMO injetadas através de diferentes vias de administração em animais com 1 a 3 dias de pós-infarto. IV $(n=15)$, IC $(n=12)$, ICO $(n=13)$ e IM $(n=17)$ correspondem, respectivamente, às vias de administração intravenosa, intracavitária, intracoronariana e intramiocárdica.

Curiosamente, nos animais que receberam as CMO após 7 dias do infarto, foram encontrados valores menores de radioatividade nos mesmos órgãos avaliados, porém com perfil similar de biodistribuição entre as vias de administração testadas (figura 7). 


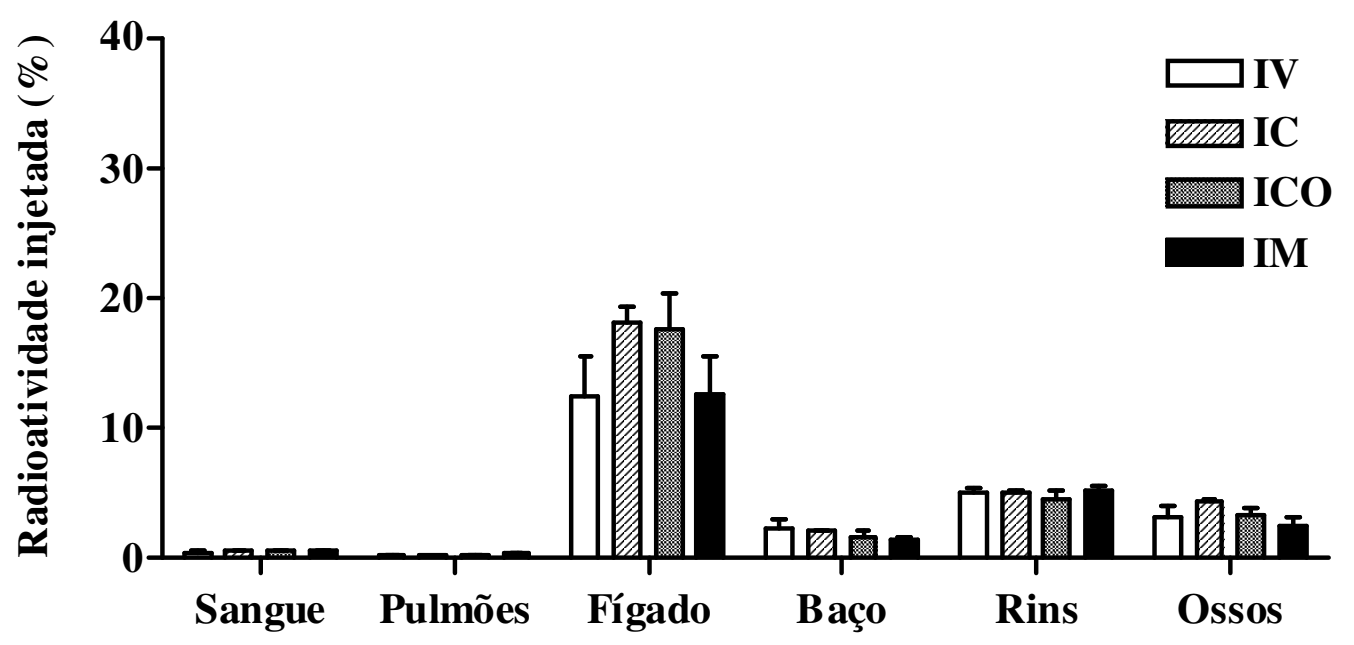

Figura 7. Biodistribuição das ${ }^{99 \mathrm{~m}} \mathrm{Tc}-\mathrm{CMO}$ injetadas através de diferentes vias de administração em animais com 7 dias de pós-infarto. IV $(n=5)$, IC $(n=5)$, ICO (n = 4) e IM ( $n=4)$ correspondem, respectivamente, às vias de administração intravenosa, intracavitária, intracoronariana e intramiocárdica.

\subsection{VEÍCULO DE BIOPOLÍMERO COMO ESTRATÉGIA PARA MELHORAR}

\section{A RETENÇÃo CARdíACA dAS CÉlulas TRANSPLANTAdAS NAS} PRIMEIRAS 72 HORAS APÓS O INFARTO.

Com o objetivo de otimizar a retenção de CMO injetadas por via intramiocárdica nos primeiros dias após o infarto (1 a 3 dias), dado que apenas $7 \%$ do total da radioatividade injetada permaneceu no coração após 24 horas do enxerto, e considerando que esse é um intervalo importante onde há incremento na expressão de citocinas e outras moléculas importantes para o homing de células-tronco, um polímero autólogo de 
fibrina foi utilizado como veículo para a injeção das CMO, com o objetivo de testar se o biopolímero poderia melhorar a retenção das células.

Os valores de radioatividade no coração dos animais que receberam CMO combinadas com o polímero de fibrina 24 horas após o infarto pela via IM foram significativamente maiores que àqueles dos animais que receberam as CMO em veículo padrão (meio de cultura DMEM) pela mesma via $(17,12 \pm 2,61$ vs. $6,84 \pm 1,17 \%, p=$ 0,0005). Figura 8.

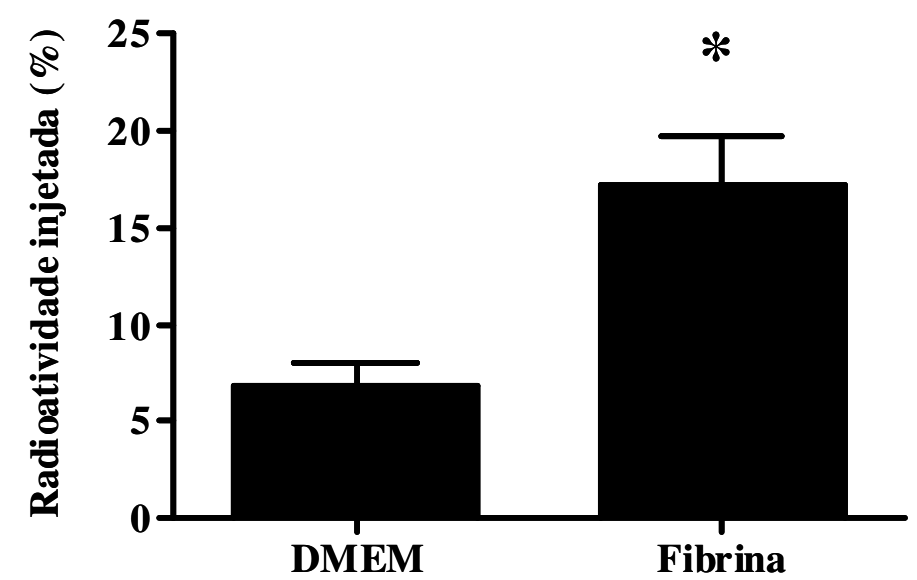

Figura 8. Retenção cardíaca de CMO injetadas com biopolímero de fibrina $(\mathrm{n}=22)$ ou com DMEM $(\mathrm{n}=$ $15)$. * $(p<0,01)$ indica diferença estatisticamente significativa entre os grupos. 
Posteriormente, para verificar se o aumento da radioatividade retida observada no grupo fibrina não era conseqüência do aprisionamento do marcador livre dentro da matriz do polímero, $10 \mu \mathrm{L}$ do sobrenadante contendo [ $\left.{ }^{99 \mathrm{~m}} \mathrm{Tc}\right]$ tecnécio extruído das CMO foram adicionados à solução de fibrinogênio antes de ser adicionada a trombina. Após 24 horas de incubação em $500 \mu \mathrm{L}$ de meio de cultura DMEM e duas lavagens consecutivas em PBS, apenas $1,29 \pm 0,07 \%$ do total da radioatividade permaneceu ligada ao polímero de fibrina. Considerando então que o $\left[{ }^{99 \mathrm{~m}} \mathrm{Tc}\right]$ tecnécio livre foi lavado para fora da matriz do polímero de fibrina (eliminado), os elevados valores de radioatividade encontrados no grupo fibrina são provavelmente representativos do incremento na retenção das células transplantadas.

O aumento da retenção cardíaca das CMO após o uso de matriz de fibrina foi também verificado através de análise histológica do coração. Ratos Lewis foram submetidos à isquemia cardíaca e transplantados intramiocardicamente com fibroblastos cardíacos geneticamente modificados para expressar, de maneira ubíqua, a enzima beta galactosidase; essa proteína foi utilizada como repórter para indicar a presença e localização dos fibroblastos implantados. Os animais foram sacrificados 24 horas depois do implante das células para a análise histológica dos corações.

Vale ressaltar que esse tipo celular foi eleito baseado em suas características satisfatórias como vetor de expressão e a elevada eficiência de transfecção dessas células com vetores virais. A figura 9 apresenta secções histológicas obtidas de animais que receberam essas células associadas ao biopolímero de fibrina comparadas às secções 
obtidas dos animais que receberam as mesmas células transplantadas em meio de cultura DMEM, o veículo padrão.
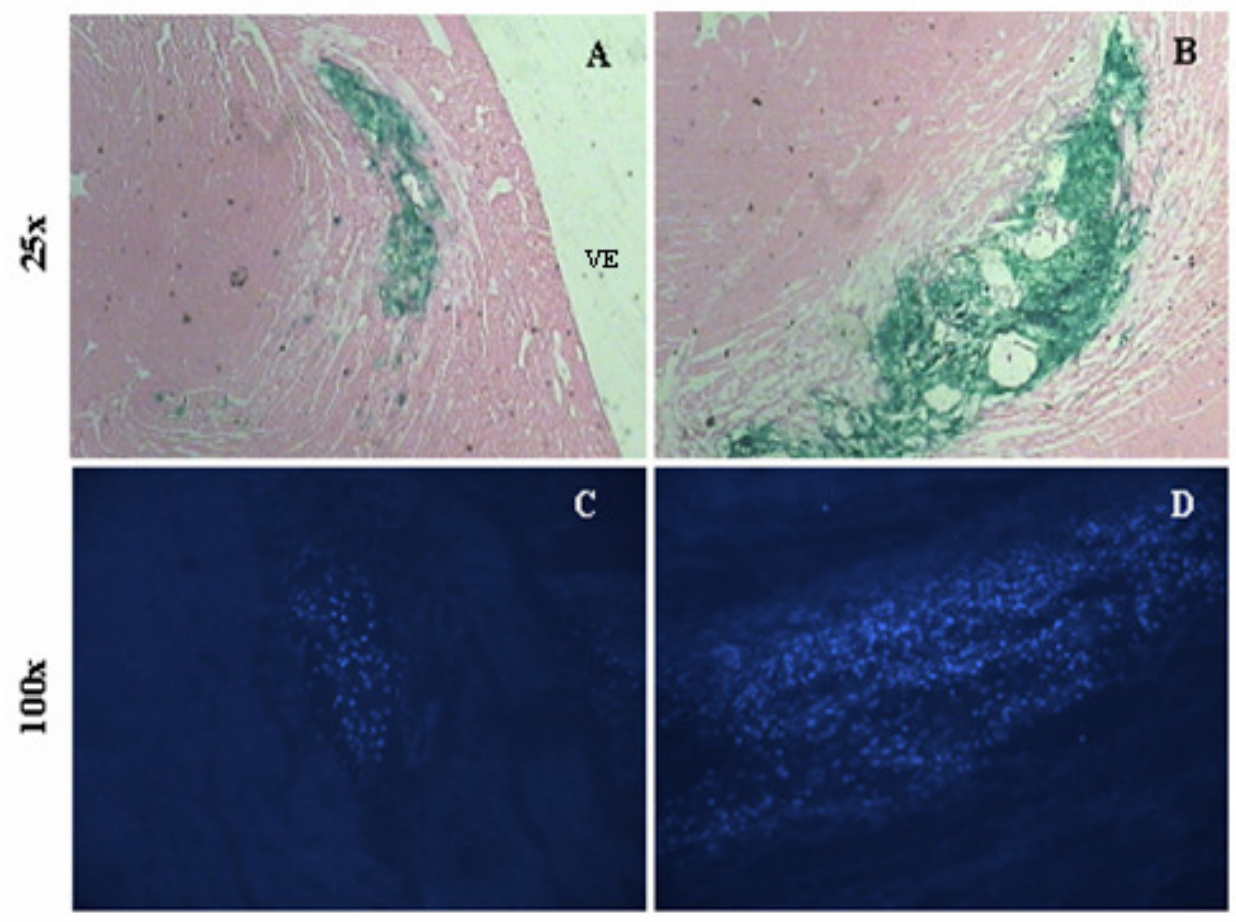

Figura 9. Secções histológicas de corações de ratos obtidas 24 horas depois do transplante de fibroblastos cardíacos expressando beta galactosidase via IM em meio de cultura DMEM ( $A$ e $C$ ) ou em biopolímero de fibrina $(B$ e $D)$. Em $A$ e $B$ as secções cardíacas foram submetidas ao ensaio enzimático colorimétrico para beta galactosidase (verde) e $C$ e $D$ são as secções observadas em microscopia de fluorescência para marcação de núcleos celulares com DAPI (azul). VE indica ventrículo esquerdo.

A retenção de células no coração após o uso de matriz de fibrina foi também acompanhada por 30 dias com o objetivo de verificar se o acúmulo das células era apenas um fenômeno agudo derivado da polimerização imediata da fibrina. Através 
desse experimento pudemos avaliar se após a dissociação e reabsorção da matriz por macrófagos, as células permaneciam no tecido cardíaco.

Células-tronco obtidas do tecido adiposo (CTTA) de ratos Lewis foram marcadas com CM-DiL, um corante vital e injetadas através da via intramiocárdica em associação com o polímero de fibrina. Os animais foram sacrificados 30 dias após o transplante das células. A análise histológica dos corações desses animais está apresentada na figura 10.

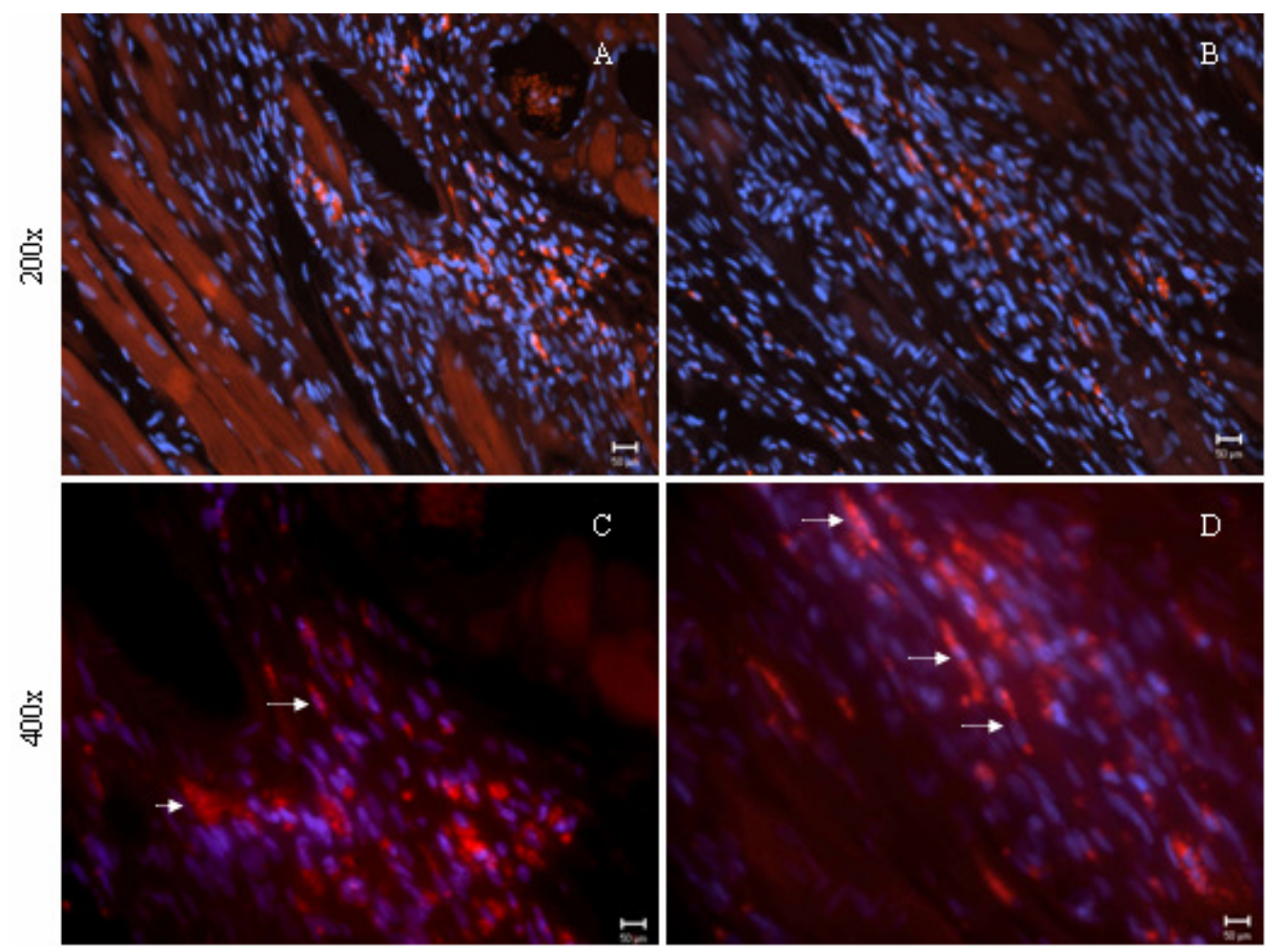

Figura 10. Secção histológica transversal do coração de um animal 30 dias após ser transplantado com CTTA em associação com fibrina por injeção intramiocárdica, observada em microscopia de fluorescência. As setas indicam as CTTA (DiL vermelho) e os núcleos estão evidenciados pela marcação com DAPI (azul). $A$ e $B$ são visualizações com magnitude de 200 x e $C$ e $D 400$ x. 
Conforme a figura acima se observa claramente a presença das CTTA 30 dias após o transplante. As células permaneceram no coração mesmo depois da provável degradação da fibrina ${ }^{48}$. Esse dado confirma o potencial emprego da fibrina como matriz biológica para a incorporação das células na abordagem de terapia celular.

\subsection{EFEITO DAS DIFERENÇAS NA RETENÇÃO DE CÉLULAS DA MEDULA ÓSSEA SOBRE A FUNÇÃO CARDÍACA DE RATOS INFARTADOS}

Para examinar se as diferenças observadas na retenção cardíaca de CMO influenciaram o impacto do remodelamento cardíaco sobre o desempenho cardíaco dos animais, foi realizada a avaliação hemodinâmica da função ventricular, no estado basal e durante o aumento súbito na pós-carga, nos animais cujas CMO foram administradas por via intravenosa ou por via intramiocárdica com e sem fibrina como veículo.

A tabela abaixo descreve os detalhes dos grupos experimentais avaliados. 


\begin{tabular}{cccc}
\hline & IAM & Conteúdo & Via de administração \\
\hline \hline SHAM & - & - & - \\
M - IM & + & meio de cultura & intramiocárdica $(\mathrm{IM})$ \\
F - IM & + & fibrina & intramiocárdica (IM) \\
CMO - IV & + & CMO $\left(1 \times 10^{6}\right)$ & intravenosa (IV) \\
CMO - IM & + & CMO $\left(1 \times 10^{6}\right)$ & intramiocárdica (IM) \\
CMO+F - IM & + & CMO $\left(1 \times 10^{6}\right)$ & intramiocárdica (IM) \\
\hline
\end{tabular}

Tabela 2. Grupos experimentais utilizados no estudo. SHAM, M-IM, F-IM, CMO-IV, CMO-IM e CMO+F-IM indicam, respectivamente, os grupos não-infartado e não-tratado, infartado e não-tratado, infartado e com injeção intramiocárdica (IM) de meio de cultura, infartado e com injeção IM de fibrina, infartado e com injeção intravenosa (IV) de células da medula óssea (CMO), infartado e com injeção IM de CMO em meio de cultura e infartado e com injeção IM de CMO em fibrina. IAM (+) indica a presença de infarto agudo do miocárdio (IAM) e (-) indica a ausência de IAM.

\subsubsection{Avaliação Morfométrica dos Corações}

\section{Tamanho do infarto}

A análise histológica dos corações infartados pela coloração de picrossírius red não mostrou diferença estatisticamente significante no tamanho de infarto, medido pela percentagem média do perímetro do ventrículo esquerdo ocupado por colágeno transmural, entre os grupos avaliados [M-IM: $31,21 \% \pm 1,99$; F-IM: $24,76 \% \pm 2,27$; CMO-IV: 27,51\% $\pm 2,67$; CMO-IM: 28,25\% $\pm 3,41 ;$ CMO+F-IM: 26,66\% $\pm 1,04 ;(p=$ 0.6384)]. Figura 11. 


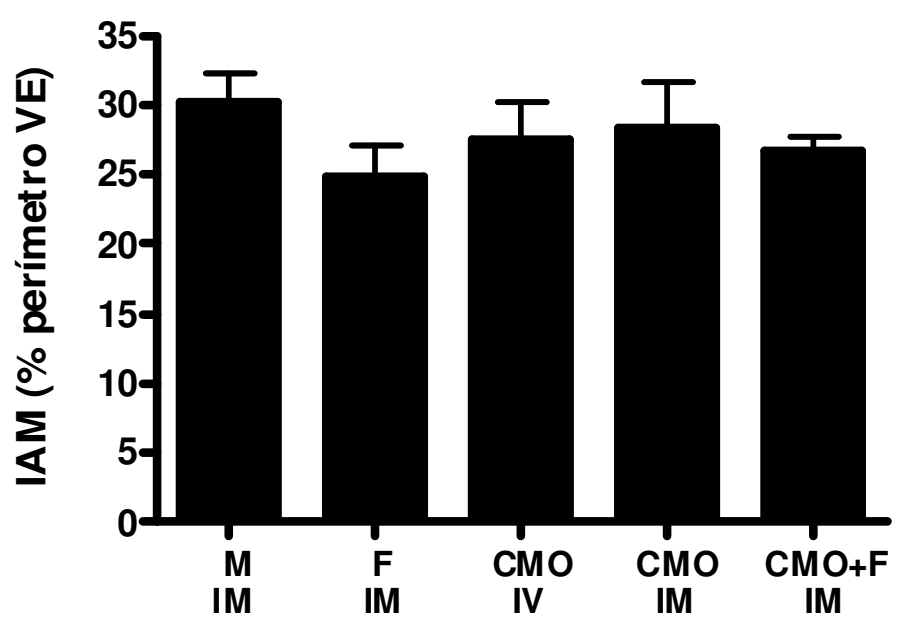

Figura 11. Avaliação histológica do tamanho do infarto. As barras representam a \% média ( \pm erro padrão da média) do perímetro do ventrículo esquerdo com colágeno transmural (cicatriz). M-IM $(\mathrm{n}=4)$, FIM ( $=4)$, CMO-IV ( $=5)$, CMO-IM $(\mathrm{n}=4)$ e CMO+F-IM $(\mathrm{n}=8)$ indicam, respectivamente, os grupos: meio de cultura injetado intramiocardicamente, fibrina injetada intramiocardicamente, $\quad \mathrm{CMO}$ injetadas intravenosamente, $\quad \mathrm{CMO}$ injetadas intramiocardicamente com meio de cultura e CMO injetadas intramiocardicamente com fibrina.

\section{Perímetro do ventrículo esquerdo}

O processo de reparo do tecido cardíaco lesado por isquemia envolve a substituição do tecido necrótico por um tecido fibroso, de cicatrização, rico em colágeno. A presença desse tecido neoformado de natureza não-contrátil implica em adaptações do órgão, especialmente morfológicas. O remodelamento ventricular é um processo no qual a arquitetura ventricular é reorganizada em resposta à nova constituição tecidual, traduzido em alteração da geometria da cavidade do ventrículo 
esquerdo. A evolução do remodelamento é caracterizada pela expansão da cavidade, cuja dimensão está diretamente relacionada ao tamanho da lesão.

A figura 12 mostra os perímetros observados nos corações dos animais nos diferentes grupos analisados.

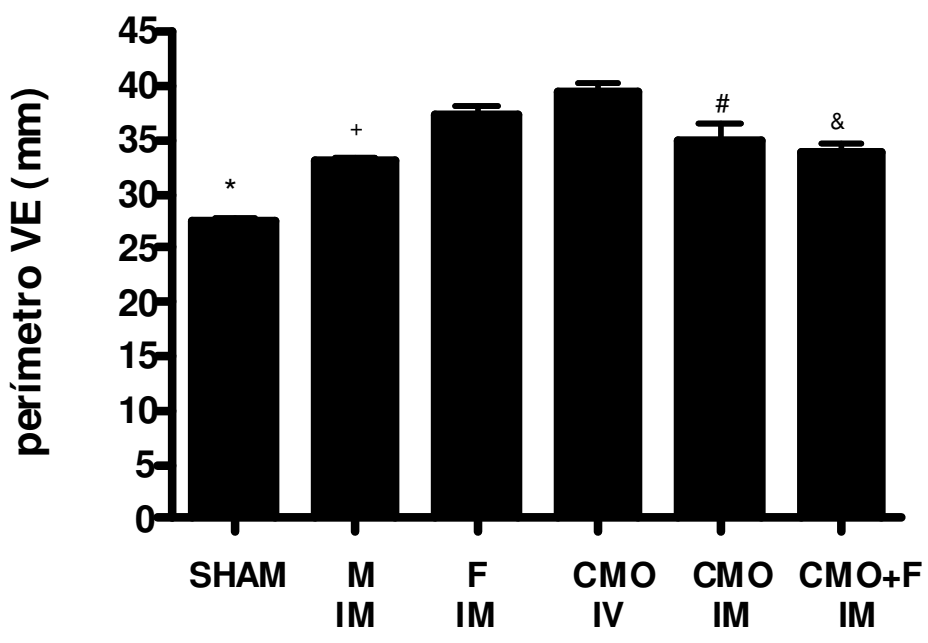

Figura 12. Avaliação histológica do perímetro do ventrículo esquerdo (VE). As barras representam a \% média ( \pm erro padrão da média) do perímetro do VE em milímetros. M-IM $(\mathrm{n}=4)$, F-IM $(\mathrm{n}=4)$, CMO-IV $(\mathrm{n}=5)$, CMO-IM $(\mathrm{n}=4)$ e CMO+F-IM $(\mathrm{n}=8)$ indicam, respectivamente, os grupos: meio de cultura injetado intramiocardicamente, fibrina injetada intramiocardicamente, $\quad \mathrm{CMO}$ injetadas intravenosamente, $\quad \mathrm{CMO}$ injetadas intramiocardicamente com meio de cultura e CMO injetadas intramiocardicamente com fibrina. * indica diferença com os demais grupos $(p<0.001)$; + indica diferença com os grupos F-IM e CMO - IV $(p<$ $0,01)$, \# indica diferença com o grupo CMO - IV $(p<$ $0,01)$ e $\&$ indica diferença com os grupos F-IM $(p<$ $0,05)$ e CMO - IV $(p<0,01)$.

Conforme mostrado na figura acima, o perímetro da circunferência do ventrículo esquerdo foi maior nos animais infartados que receberam apenas fibrina via intramiocárdica (F - IM: 37,23 $\pm 0,91 \mathrm{~mm}$ ) e naqueles em que as CMO foram 
administradas intravenosamente (CMO - IV: 39,48 \pm 0,77 mm). Como esperado, os menores valores de perímetro do VE foram observados nos animais do grupo SHAM $(27,5 \pm 0,18 \mathrm{~mm})$ comparados aos demais grupos $(p<0,001)$.

O valor médio do perímetro do VE no grupo com injeção intramiocárdica de CMO (CMO-IM), foi menor que o valor obtido no grupo CMO - IV $(35,04 \pm 1,34 \mathrm{~mm}$ vs. $39,48 \pm 0,77 \mathrm{~mm} ; p<0,01)$. Similarmente o valor médio do perímetro do VE foi menor no grupo CMO+F - IM que os valores observados nos animais dos grupos F IM e CMO - IV (33,86 $\pm 0,74 \mathrm{~mm}$ vs. 37,23 $\pm 0,91 ; p<0,05$ e 39,48 $\pm 0,77 \mathrm{~mm} ; p<$ $0,05)$, respectivamente.

Curiosamente, o valor médio do perímetro do VE no grupo M - IM (nãotratados com células), foi menor que o observado nos animais do grupo F - IM e CMO IV $(32,97 \pm 0,44 \mathrm{~mm} v s .37,23 \pm 0,91 \mathrm{~mm} ; p<0,001$ e $39,48 \pm 0,77 \mathrm{~mm} ; p<0,001)$

\section{Espessura da cicatriz e da zona de borda da cicatriz}

$\mathrm{O}$ adelgaçamento da parede infartada durante o processo de formação da cicatriz é também observado no remodelamento ventricular. Nesse estudo foram avaliadas a espessura da cicatriz e a espessura da área de borda, região adjacente à área infartada.

De forma interessante, os animais em que as $\mathrm{CMO}$ foram injetadas intramiocardicamente associadas à fibrina (CMO+F - IM) exibiram cicatriz mais espessa que os animais infartados não-tratados (M-IM) e nos tratados intravenosamente 
(CMO-IV) $(1,58 \mathrm{~mm} \pm 0,15$ vs. $0,70 \mathrm{~mm} \pm 0,13(p<0,05)$ e $0,85 \mathrm{~mm} \pm 0,16(p<0,05)$

Figura 13.
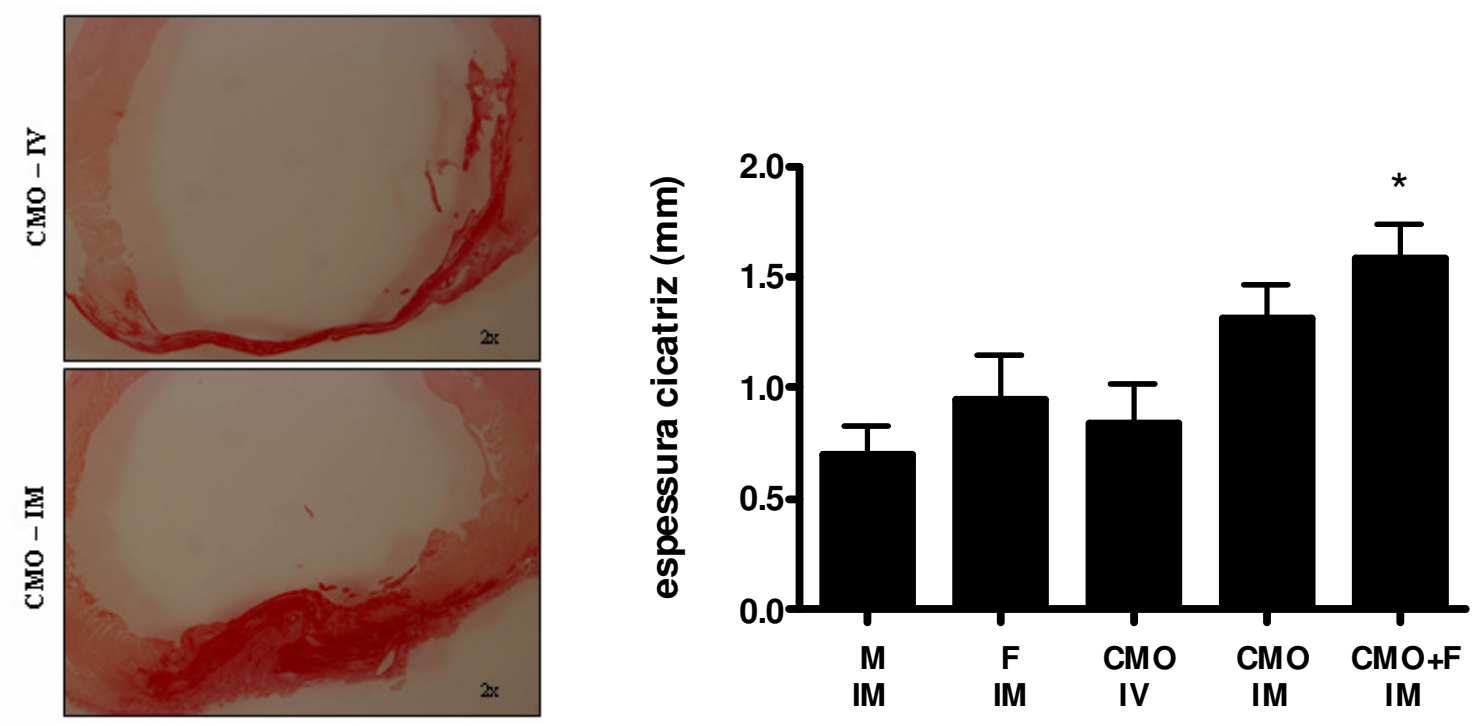

Figura 13. Avaliação histológica da espessura da cicatriz do ventrículo esquerdo (VE). As barras representam a média ( \pm erro padrão da média) da espessura em milímetros $(\mathrm{mm})$ da cicatriz. M-IM (n = 4), F-IM ( $\mathrm{n}=4)$, CMO-IV $(\mathrm{n}=5), \mathrm{CMO}-\mathrm{IM}(\mathrm{n}=4)$ e CMO+F-IM $(\mathrm{n}=8)$ indicam, respectivamente, os grupos: meio de cultura injetado intramiocardicamente, fibrina injetada intramiocardicamente, $\mathrm{CMO}$ injetadas intravenosamente, CMO injetadas intramiocardicamente com meio de cultura e CMO injetadas intramiocardicamente com fibrina. * indica diferença com os grupos M-IM e CMO-IV $(p<$ $0.05)$.

Com relação à espessura da zona de borda (BZ), também foi observada maior espessura no grupo CMO+F - IM comparado aos grupos M-IM, F-IM e CMO-IV, respectivamente $[1,63 \mathrm{~mm} \pm 0,09$ vs. $0,87 \mathrm{~mm} \pm 0,15(p<0,01), 1,01 \mathrm{~mm} \pm 0,19(p<$ 0,05) e 1,06 mm $\pm 0,12(p<0,05)]$. O grupo CMO-IM também apresentou espessura da $\mathrm{BZ}$ maior que o grupo M-IM $(1,53 \mathrm{~mm} \pm 0,06$ vs. $0,87 \mathrm{~mm} \pm 0,15 ; p<0,05)$. Figura 14. 


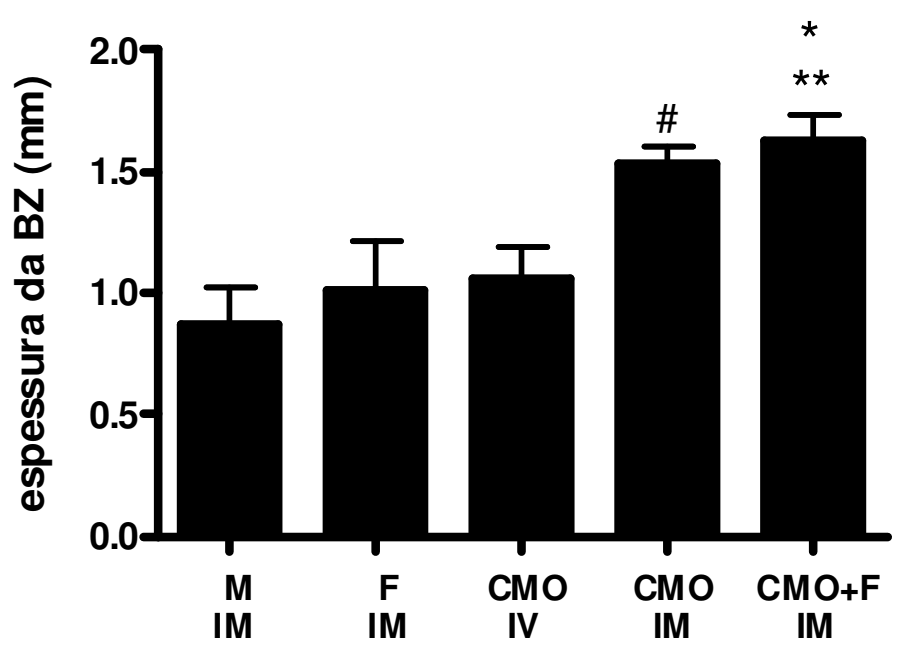

Figura 14. Avaliação histológica da espessura da zona de borda do ventrículo esquerdo (VE). As barras representam a média ( \pm erro padrão da média) da espessura em milímetros (mm) da cicatriz. M-IM ( $\mathrm{n}=4)$, F-IM $(\mathrm{n}=4)$, CMO-IV ( $\mathrm{n}=$ 5), CMO-IM ( $n=4)$ e CMO+F-IM $(n=8)$ indicam, respectivamente, os grupos: meio de cultura injetado intramiocardicamente, fibrina injetada intramiocardicamente, $\mathrm{CMO}$ injetadas intravenosamente, $\quad \mathrm{CMO}$ injetadas intramiocardicamente com meio de cultura e CMO injetadas intramiocardicamente com fibrina. * indica diferença com o grupo M-IM $(p<0,01)$, \# indica diferença com o grupo M-IM $(p<0,05) \mathrm{e} * *$ indica diferença com os grupos F-IM e CMO-IV ( $p$ $<0.05)$. 


\subsubsection{Avaliação Hemodinâmica da Função Ventricular}

As alterações morfológico-estruturais que ocorrem após o infarto repercutem na contratilidade do músculo cardíaco e conseqüentemente na função do órgão. A avaliação hemodinâmica direta da função ventricular foi realizada nos ratos estudados, no estado basal e durante o estresse de pós-carga.

O desempenho do ventrículo esquerdo pode ser demonstrado quando há aumento na resistência vascular periférica, como quando um vasoconstritor é administrado (fenilefrina). Como a pressão gerada no interior da câmara ventricular esquerda deve ser superior à pressão aórtica para ocorrer a ejeção durante a sístole, entende-se que, nessas circunstâncias, o trabalho requisitado ao ventrículo esquerdo seja maior. Portanto, a resposta hemodinâmica frente ao aumento súbito na pós-carga permite a distinção entre um coração saudável, cuja capacidade contrátil está mantida, e outro com comprometimento contrátil traduzido em deficiência funcional

A figura 15 ilustra o comportamento hemodinâmico de dois ratos durante o aumento súbito na pós-carga; um deles com o coração sadio e o outro infartado. 


\section{Normal}
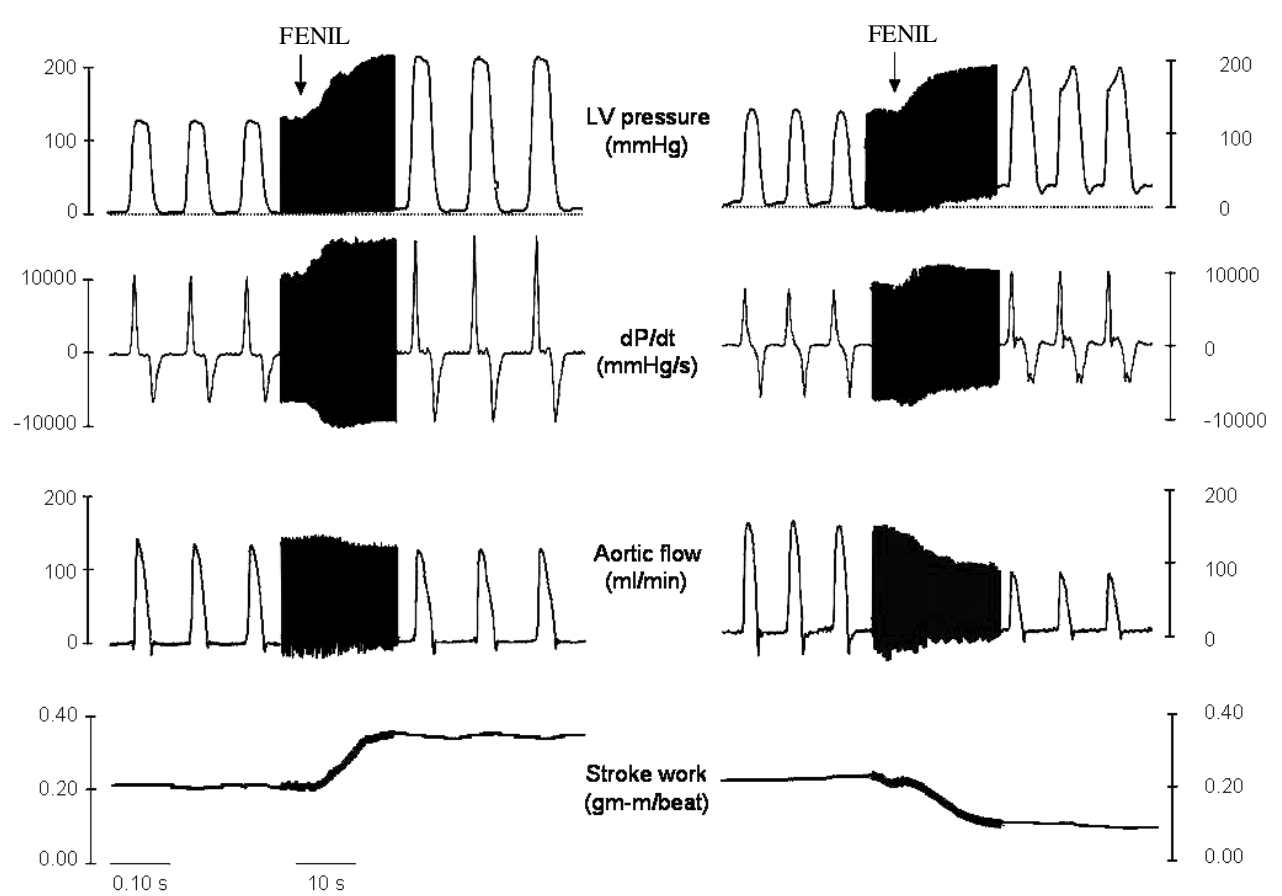

Figura 15. Parâmetros hemodinâmicos em rato normal e infartado frente ao aumento súbito na pós-carga com administração de fenilefrina (FENIL). A primeira linha mostra o registro da pressão no ventrículo esquerdo em milímetros de mercúrio $(\mathrm{mm}$ $\mathrm{Hg}$ ), a segunda linha mostra o registro da derivada temporal da pressão máxima $(+\mathrm{dP} / \mathrm{dt}$ e $-\mathrm{dP} / \mathrm{dt})$, a terceira linha mostra o registro do fluxo em mililitros por minuto (mL/min) na artéria aorta e a quarta linha mostra a geração de trabalho (g.m/batimento). Gentilmente cedido por Leonardo dos Santos.

O painel acima ilustra uma situação onde há aumento súbito na pressão em ratos infartados e não-infartados. Nessa condição, a bomba cardíaca melhora seu desempenho para que não haja prejuízo na ejeção do sangue.

A primeira derivada temporal da pressão intraventricular $(\mathrm{dP} / \mathrm{dt})$ traduz a velocidade de variação da pressão intraventricular na sístole ( $\mathrm{dP} / \mathrm{dt}$ positiva) e na 
diástole (dP/dt negativa). Esses valores são máximos durante as fases isovolumétricas do ciclo cardíaco e, portanto, estimam indiretamente a capacidade contrátil e de relaxamento do ventrículo. Durante a sobrecarga súbita, o coração saudável aumenta as dP/dt máximas positiva e negativa, sugerindo que nessa condição, aceleraram a contração e o relaxamento do miocárdio.

Ao contrário, em corações com desempenho deprimido como acontece no caso do infarto, o relaxamento é prejudicado.

A conseqüência desse comportamento é a diminuição do fluxo sanguíneo para o sistema arterial do rato infartado que, por outro lado, é mantido no rato com coração sadio. Adicionalmente, a geração de trabalho sistólico aumenta no animal "normal" em resposta à sobrecarga pressórica enquanto diminui no animal infartado.

Em resumo, o coração infartado apresenta grande prejuízo na capacidade contrátil e, como conseqüência, na capacidade de ejeção e resposta às variações hemodinâmicas sistêmicas.

Nesse estudo, os parâmetros hemodinâmicos avaliados podem ser classificados em 3 categorias: medidas de pressão intraventricular - pressão diastólica final (PDF) e pressão sistólica (PS) - , medidas de contratilidade - derivada temporal da pressão máxima $\left(+\mathrm{dP}^{\mathrm{d}} \mathrm{dt}_{\text {máx }} \mathrm{e}-\mathrm{dP} / \mathrm{dt}_{\text {máx }}\right)$ - e medidas de desempenho ventricular - índice cardíaco (IC), índice do volume sistólico (IVS) e índice do trabalho sistólico (ITS). 
Medidas de pressão intraventricular, de contratilidade e de desempenho cardíaco em condições basais de experimentação

De maneira geral, as medidas dos parâmetros hemodinâmicos no estado basal foram similares entre os grupos, com diferenças em alguns casos apenas entre os animais do grupo SHAM e os do grupo sem tratamento (M - IM). A tabela 3 mostra todas as medidas obtidas no estado basal.

Com relação às medidas de pressão intraventricular, o valor médio da pressão diastólica final foi menor nos animais do grupo SHAM que nos animais dos grupos MIM. A pressão sistólica atingiu os maiores valores nos animais do grupo SHAM comparados aos animais dos grupos M-IM e CMO-IV

É importante destacar que os valores da pressão diastólica final e sistólica dos animais tratados com CMO não foram diferentes entre si, porém nenhum desses valores é considerado patológico quanto à disfunção cardíaca.

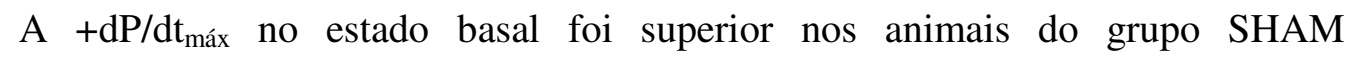
comparados aos animais dos grupos M - IM, F - IM e CMO - IV. Além disso, diferença estatisticamente significante foi observada entre os valores da $+\mathrm{dP} / \mathrm{dt}_{\text {máx }}$ do grupo CMO - IM e dos grupo M - IM e F - IM . A dP/dt máxima positiva também foi maior nos animais do grupo $\mathrm{CM}+\mathrm{F}$ - IM quando comparados aos do grupo M- IM. 
Não houve diferença entre os grupos na derivada negativa, mostrando que a velocidade de variação da pressão durante a diástole não mudou significantemente com a presença do infarto.

A análise dos dados não mostrou diferença estatisticamente significante entre os grupos com relação ao índice cardíaco e ao índice do trabalho sistólico. Isso mostra que, independentemente da presença do infarto, no estado basal os animais conseguem manter a ejeção em níveis considerados normais. 


\begin{tabular}{|c|c|c|c|c|c|c|c|}
\hline & $\begin{array}{c}\text { Sham } \\
n=5\end{array}$ & $\begin{array}{c}\mathbf{M}-\mathbf{I M} \\
\mathrm{n}=5\end{array}$ & $\begin{array}{c}\mathbf{F}-\mathbf{I M} \\
\mathrm{n}=4\end{array}$ & $\begin{array}{c}\text { CMO - IV } \\
n=6\end{array}$ & $\begin{array}{c}\text { CMO - IM } \\
n=6\end{array}$ & $\begin{array}{c}\mathbf{C M O}+\mathbf{F}-\mathbf{I M} \\
\mathrm{n}=6\end{array}$ & Valor $p$ \\
\hline PDfVE (mm Hg) & $3,78 \pm 0,91^{b}$ & $11,18 \pm 1,95$ & $10,50 \pm 2,75$ & $7,40 \pm 1,20$ & $5,50 \pm 0,86$ & $6,00 \pm 1,41$ & 0,020 \\
\hline PSVE (mm Hg) & $121,50 \pm 2,63^{\mathrm{bd}}$ & $104,10 \pm 2,81$ & $106,80 \pm 4,40$ & $102,60 \pm 4,35$ & $115,50 \pm 3,88$ & $108,80 \pm 4,78$ & 0,009 \\
\hline$+\mathrm{dP} / \mathrm{dt}_{\text {máx }}\left(\mathrm{mm} \mathrm{Hg} \cdot \mathrm{s}^{-1}\right)$ & $9.158 \pm 491,30^{\mathrm{bcd}}$ & $5.976 \pm 308,70$ & $7.062 \pm 345,60$ & $6.582 \pm 329,70$ & $8.437 \pm 786,10^{b c}$ & $7.635 \pm 272,90$ & 0,0002 \\
\hline$-\mathrm{dP} / \mathrm{dt}_{\text {máx }}\left(\mathrm{mm} \mathrm{Hg} \cdot \mathrm{s}^{-1}\right)$ & $-5.324 \pm 382,50$ & $-4.405 \pm 281,30$ & $-4.619 \pm 204,10$ & $-4.550 \pm 437,00$ & $-4.974 \pm 217,90$ & $-4.651 \pm 226,70$ & 0,30 \\
\hline $\mathrm{FC}(\mathrm{bpm})$ & $329,10 \pm 22,57$ & $309,40 \pm 13,64$ & $372,30 \pm 25,92$ & $328,00 \pm 10,24$ & $339,00 \pm 14,08$ & $341,80 \pm 8,26$ & 0,21 \\
\hline IC (mL. $\left.\min ^{-1} / \mathrm{kg}\right)$ & $143,70 \pm 15,99$ & $132 \pm 7,86$ & $162,80 \pm 14,19$ & $121,60 \pm 7,95$ & $139,80 \pm 7,52$ & $134,30 \pm 12,74$ & 0,24 \\
\hline IVS (mL.bat ${ }^{-1} / \mathrm{kg}$ ) & $0,51 \pm 0,07$ & $0,60 \pm 0,05$ & $0,48 \pm 0,07$ & $0,37 \pm 0,03^{b}$ & $0,41 \pm 0,01$ & $0,39 \pm 0,03$ & 0,03 \\
\hline ITS (gm.min ${ }^{-1} / \mathrm{kg}$ ) & $0,68 \pm 0,08$ & $0,64 \pm 0,05$ & $0,67 \pm 0,07$ & $0,48 \pm 0,05$ & $0,61 \pm 0,01$ & $0,54 \pm 0,04$ & 0,20 \\
\hline
\end{tabular}

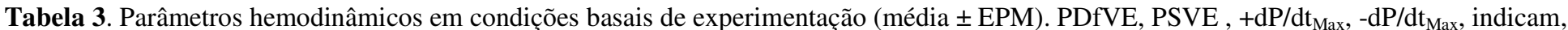
respectivamente, a pressão diastólica final no ventrículo esquerdo, a pressão sistólica no ventrículo esquerdo, as derivadas máximas da pressão

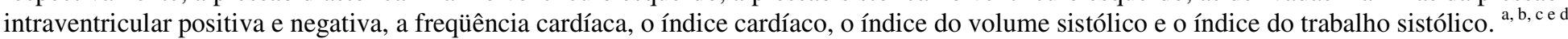
representa, respectivamente, diferença estatisticamente significante $(p<0,05)$ com os grupos SHAM, M-IM, F-IM e CMO-IV. 
Medidas de pressão, contratilidade e de desempenho cardíaco durante a sobrecarga pressórica súbita

Pressão Diastólica Final e Pressão Sistólica

Quando a sobrecarga pressórica foi induzida, diferenças entre os animais tratados com CMO foram mais claramente observadas. A figura 16 mostra as mudanças relativas ao estado basal ocorridas na pressão diastólica final.

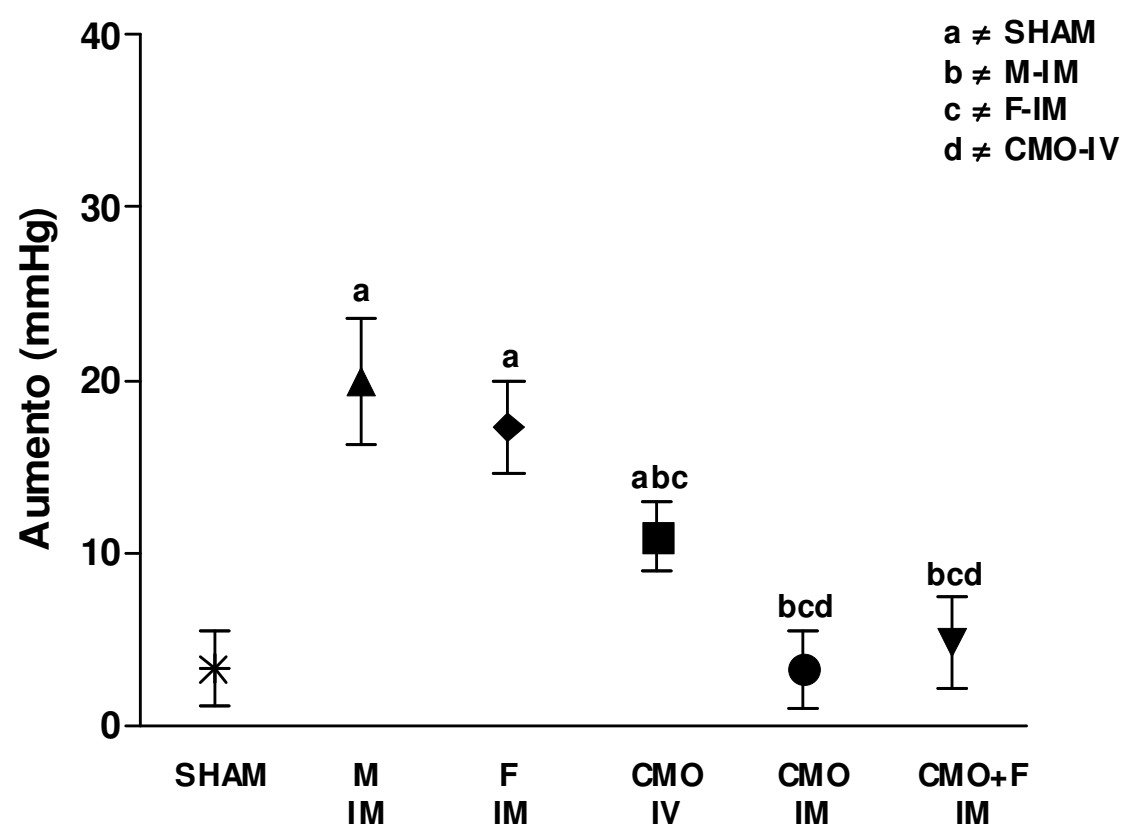

Figura 16. Aumento na pressão diastólica final durante o pico da sobrecarga. Os valores representam (média \pm EPM) em milímetros de mercúrio $(\mathrm{mm} \mathrm{Hg})$ em relação à $\mathrm{PDF}$ no estado basal. SHAM $(n=5)$, M-IM $(n=5)$, F-IM $(n=4)$, CMO-IV $(n=$ 5), CMO-IM $(\mathrm{n}=4)$ e CMO+F-IM $(\mathrm{n}=4)$ indicam, respectivamente, os grupos: meio de cultura injetado intramiocardicamente, fibrina injetada intramiocardicamente, CMO injetadas intravenosamente, CMO injetadas intramiocardicamente com meio de cultura e CMO injetadas intramiocardicamente com fibrina. $a, b, c e d$ representam diferença estatisticamente significativa com os grupos indicados na legenda. 
Conforme apresentado na figura 16, os animais que apresentaram maior aumento na pressão diastólica final (PDF), comparados com os animais do grupo SHAM, foram aqueles nos quais não foram administradas células [SHAM: 3,26 $\pm 0,97 \mathrm{~mm} \mathrm{Hg} \mathrm{vs.} \mathrm{M-}$ IM: $19,90 \pm 1,66 \mathrm{~mm} \mathrm{Hg}(p<0,001) ; \mathrm{F}-\mathrm{IM}: 17,25 \pm 1,31 \mathrm{~mm} \mathrm{Hg}(p<0,001)]$ ou quando as CMO foram administradas intravenosamente [CMO - IV: 11,00 $\pm 0,89 \mathrm{~mm}$ $\mathrm{Hg}(p<0,01)]$.

Nos animais que receberam CMO por via IM, com meio de cultura como veículo para as células $(\mathrm{CMO}-\mathrm{IM})$ ou fibrina $(\mathrm{CMO}+\mathrm{F}-\mathrm{IM})$, o aumento da PDF foi similar ao observado no grupo SHAM $(3,25 \pm 1,10 \mathrm{~mm} \mathrm{Hg} ; 4,76 \pm 1,31 \mathrm{~mm} \mathrm{Hg})$. O aumento na PDF dos animais do grupo CMO - IM foi menor que àquele obtido nos animais dos grupos M - IM, F - IM e CMO- IV, respectivamente [3,25 $\pm 1,10 \mathrm{~mm} \mathrm{Hg} \mathrm{vs.} \mathrm{19,90 \pm}$ $1,66 \mathrm{~mm} \mathrm{Hg}(p<0,001) ; 17,25 \pm 1,31 \mathrm{~mm} \mathrm{Hg}(p<0,001)$ e $11,00 \pm 0,89 \mathrm{~mm} \mathrm{Hg}(p<$ 0,01)]. Similarmente, no grupo $\mathrm{CMO}+\mathrm{F}-\mathrm{IM}$ a PDF aumentou menos que nos grupos $\mathrm{M}$ - IM, F - IM e CMO - IV, respectivamente $[4,75 \pm 1,31 \mathrm{~mm} \mathrm{Hg} v s .19,90 \pm 1,66$ ( $p<$ 0,001); 17,25 $\pm 1,31 \mathrm{~mm} \mathrm{Hg}(p<0,001)$ e $11,00 \pm 0,89 \mathrm{~mm} \mathrm{Hg}(p<0,05)]$.

Em contrapartida, não houve diferença estatisticamente significante no aumento da pressão sistólica entre os grupos avaliados $(p=0,315)$. Todos os animais foram vagotomizados bilateralmente para evitar influencia do barorreflexo no desempenho cardíaco e, por isso, não houve significante bradicardia frente ao aumento súbito da pressão em nenhum grupo (figura 17). 


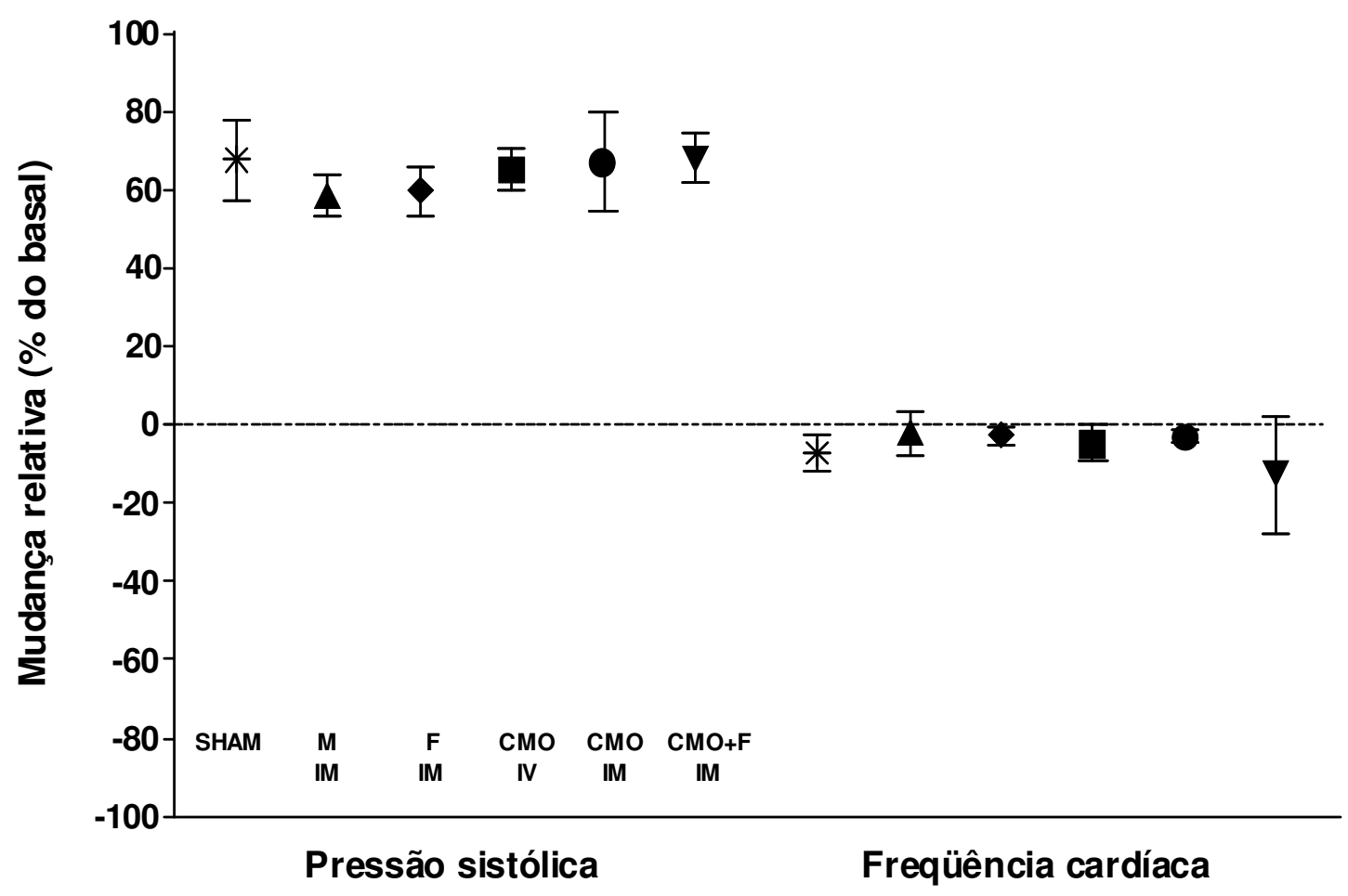

Figura 17. Mudanças na pressão sistólica e freqüência cardíaca durante o pico de aumento na pós-carga. SHAM $(n=5)$, M-IM $(n=5)$, F-IM $(n=4)$, CMO-IV $(n=5)$, CMO-IM $(n=4)$ e $\mathrm{CMO}+\mathrm{F}-\mathrm{IM}(\mathrm{n}=4)$ indicam, respectivamente, os grupos: meio de cultura injetado intramiocardicamente, fibrina injetada intramiocardicamente, CMO injetadas intravenosamente, CMO injetadas intramiocardicamente com meio de cultura e CMO injetadas intramiocardicamente com fibrina. 
Medidas de contratilidade

A derivada temporal da pressão intraventricular foi avaliada também durante a sobrecarga súbita de pressão. A figura 18 mostra os valores médios da $+\mathrm{dP} / \mathrm{dt}_{\text {máx }} \mathrm{e}-$ $\mathrm{dP} / \mathrm{dt}_{\text {máx }}$ nos grupos avaliados.

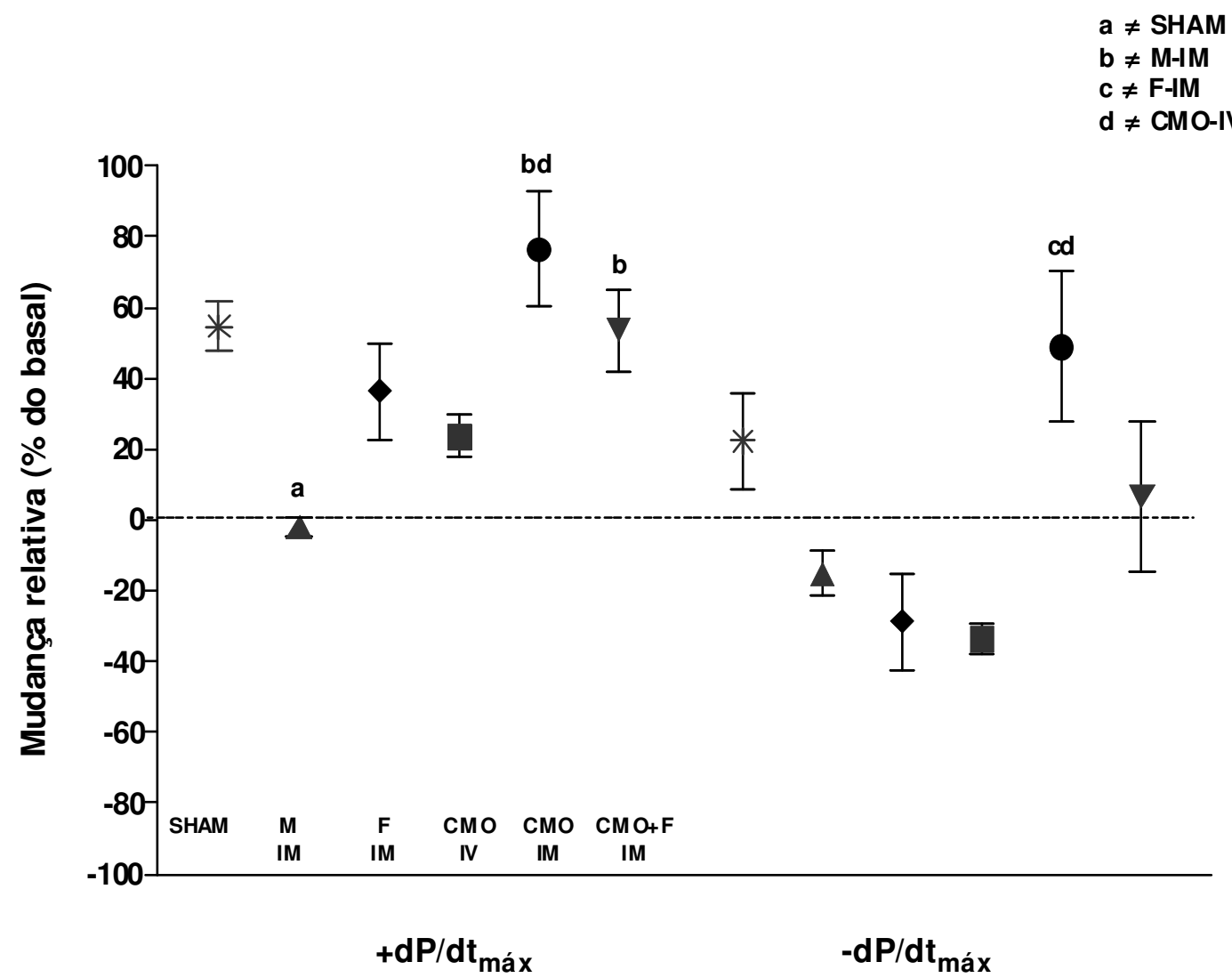

Figura 18. Derivada temporal da pressão intraventricular $(\mathrm{dP} / \mathrm{dt})$ em condição de sobrecarga pressórica. Os valores em cada grupo representam a média $( \pm$ EPM) da mudança percentual relativa aos valores desse parâmetro no estado basal. SHAM $(n=5)$, M-IM $(n=5)$, F-IM $(n=$ 4), CMO-IV ( $=5)$, CMO-IM $(n=4)$ e CMO+F-IM $(n=4)$ indicam, respectivamente, os grupos: meio de cultura injetado intramiocardicamente, fibrina injetada intramiocardicamente, CMO injetadas intravenosamente, CMO injetadas intramiocardicamente com meio de cultura e CMO injetadas intramiocardicamente com fibrina. $a, b, c e d$ representam diferença estatisticamente significativa com os grupos indicados na legenda. 


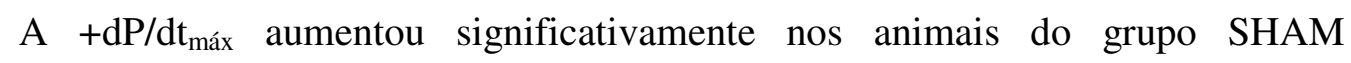
comparados aos animais do grupo $\mathrm{M}-\mathrm{IM}(54,56 \pm 6,94 \%$ vs. $-2,02 \pm 2,37 ; p<0,01)$. O aumento foi ainda maior nos animais do grupo CMO - IM, comparados aos animais do grupo M - IM e CMO - IV (76,50 $\pm 16,36 \%$ vs. $-2,02 \pm 2,37 \% ; p<0,001$ e 23,80 \pm $5,82 \% ; p<0,05)$ e CMO+F - IM, comparados aos animais $\mathrm{M}-\mathrm{IM}(53,40 \pm 11,75 \%$ vs. $-2,02 \pm 2,37 \% ; p<0,01)$

A - $d P / d_{\text {máx }}$ diminuiu nos animais não-tratados com células $[\mathrm{M}-\mathrm{IM}(-15,10 \pm$ $6,37 \%)$ e F - IM $(-28,75 \pm 13,51 \%)]$ e naqueles em que as células foram administradas intravenosamente [CMO - IV $(-33,60 \pm 4,51 \%)]$. Aumento significativo foi observado apenas nos animais do grupo CMO - IM (49,00 $\pm 21,39 \%)$ comparados aos animais dos grupos F - IM $(-28,75 \pm 13,51 ; p<0,05)$ e CMO - IV $(-33,60 \pm 4,51 \% ; p<0,01)$. 


\section{Medidas de Desempenho Cardíaco}

O índice cardíaco piorou pronunciadamente nos animais infartado não-tratados com células e no grupo dos injetados intravenosamente com CMO (em relação à medida obtida no estado basal) quando comparados aos animais não-infartados (SHAM: -8,54 \pm $2,78 \%$ vs. $\mathrm{M}$ - IM: $-62,50 \pm 5,50 \% ; p<0,001, \mathrm{~F}-\mathrm{IM}:-62,25 \pm 3,70 \% ; p<0,001 \mathrm{e}$ CMO - IV: $-49,40 \pm 5,26 \%$; $p<0,001$ ) (figura 19). Essa piora relativa também foi maior que a observada nos animais em que as CMO foram administradas intramiocardicamente em meio de cultura (CMO - IM: $-26,50 \pm 2,63 \%$ vs. M - IM: $-62,50 \pm 5,50 \% ; p<$ 0,001, F - IM: $-62,25 \pm 3,70 \% ; p<0,001$ e CMO - IV: $-49,40 \pm 5,26 \% ; p<0,05$ ) e em fibrina (CMO+F - IM: $-36,50 \pm 6,65 \%$ vs. $\mathrm{M}-\mathrm{IM}:-62,50 \pm 5,50 \% ; p<0,01, \mathrm{~F}-\mathrm{IM}$ : $62,25 \pm 3,70 \% ; p<0,05$ e SHAM: $-8,54 \pm 2,78 \% ; p<0,01)$.

Com relação ao índice do volume sistólico ejetado, novamente foi observada diferença não apenas entre os animais não-tratados com células e os animais do grupo SHAM, mas também entre os animais tratados com CMO.

A mudança relativa ao estado basal foi muito pequena, praticamente nula, nos animais do grupo SHAM comparadas às grandes mudanças observadas nos animais dos grupos M - IM, F - IM e CMO - IV respectivamente [-4,55 $\pm 2,19 \%$ vs. $-57,40 \pm 4,41 \%$ $(p<0,001) ;-60,50 \pm 3,66 \%(p<0,001)$ e $-48,60 \pm 4,34 \%(p<0,001)]$.

A queda do índice do volume sistólico ejetado também foi inferior nos animais do grupo CMO - IM comprados aos grupos M - IM, F - IM, CMO - IV, mas ainda numericamente piores que os animais SHAM $[-24,00 \pm 2,48 \%$ vs. $-57,40 \pm 4,41 \%$ ( $p<$ 
$0,001) ;-60,50 \pm 3,66 \%(p<0,001)$ e $-48,60 \pm 4,34 \%(p<0,01) ;-4,55 \pm 2,19 \%(\mathrm{p}<$ $0,05)]$.

Adicionalmente, menor queda no índice do volume sistólico foi observada nos animais do grupo $\mathrm{CMO}+\mathrm{F}$ - IM comparados aos animais dos grupos $\mathrm{M}$ - IM, F - IM, CMO - IV, porém numericamente piores que os animais SHAM $[-28,50 \pm 5,75 \%$ vs. $57,40 \pm 4,41 \%(p<0,001) ;-60,50 \pm 3,66 \%(p<0,001)$ e $-48,60 \pm 4,34 \%(p<0,05) ;-$ $4,55 \pm 2,19 \%(\mathrm{p}<0,01)]$.

Finalmente, o trabalho sistólico, parâmetro que melhor traduz o desempenho ventricular, aumentou significativamente apenas nos animais do grupo SHAM e nos animais infartados que receberam $\mathrm{CMO}$ por via intramiocárdica $(\mathrm{CMO}-\mathrm{IM}$ e $\mathrm{CMO}+\mathrm{F}$ - IM), independentemente do uso da fibrina $(56,70 \pm 2,32 \% ; 27,75 \pm 0,85 \%$ e $20,55 \pm$ 8,70\%) respectivamente. Os animais dos grupos $\mathrm{M}$ - IM, F - IM e CMO - IV mostraram prejuízo na função ventricular visto que diminuíram a geração de trabalho em relação ao basal $(-52,54 \pm 4,66 \% ;-42,25 \pm 5,96$ e $-22,60 \pm 8,70 \%$ respectivamente).

Portanto, quando os grupos foram comparados, diferença estatisticamente significativa foi igualmente observada entre os animais com aumento na geração de trabalho sistólico (SHAM, CMO - IM e CMO+F - IM) e naqueles onde houve dificuldade em mantê-lo (M - IM, F - IM e CMO - IV; $p<0,001)$. A figura 19 ilustra os valores médios da mudança percentual observada nos animais dos grupos avaliados. 


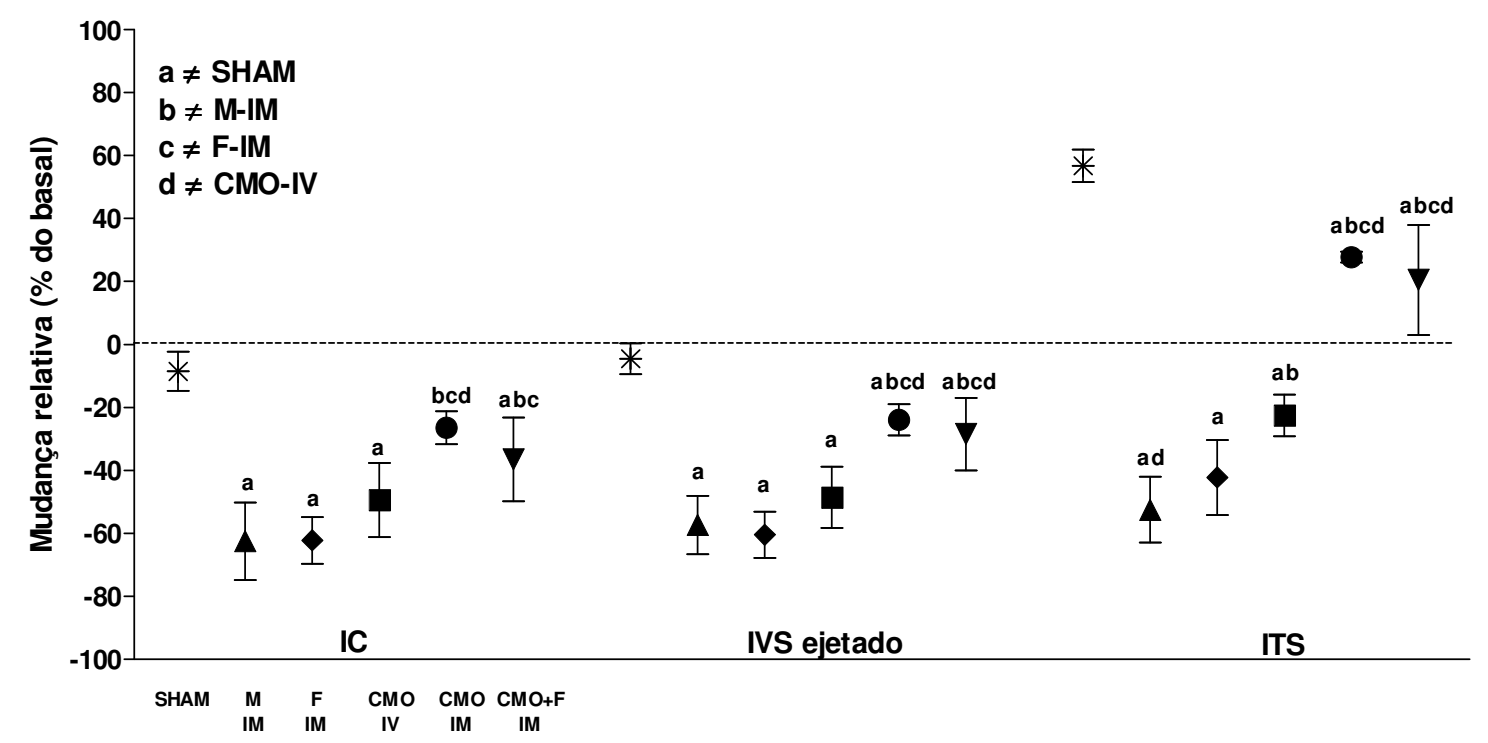

Figura 19. Mudança relativa no índice cardíaco (IC), índice do volume sistólico ejetado (IVS) e índice do trabalho sistólico (ITS) em ratos infartados dos diferentes grupos experimentais avaliados. Os valores em cada grupo representam a média $( \pm$ EPM) da mudança percentual em relação aos parâmetros medidos no estado basal. SHAM ( $=5)$, M-IM $(n=5)$, F-IM $(n=4)$, CMO-IV $(n=5)$, CMO-IM $(n=4)$ e CMO+FIM $(n=4)$ indicam, respectivamente, os grupos: meio de cultura injetado intramiocardicamente, fibrina injetada intramiocardicamente, CMO injetadas intravenosamente, CMO injetadas intramiocardicamente com meio de cultura e CMO injetadas intramiocardicamente com fibrina. $a, b, c$ e $d$ representam diferença estatisticamente significativa com os grupos indicados na legenda.

Os dados individuais das relações estabelecidas entre a sobrecarga pressórica e as mudanças no volume sistólico ejetado (painel A) e na geração de trabalho sistólico (painel B) estão apresentados na figura 20 sob a forma de regressão linear. 
SHAM

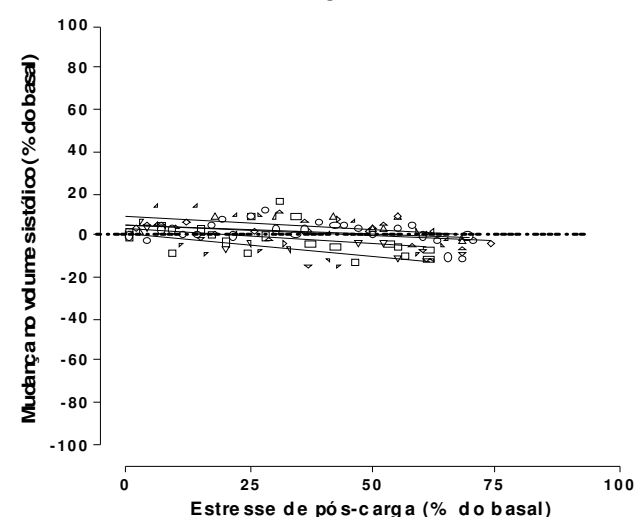

$F-I M$

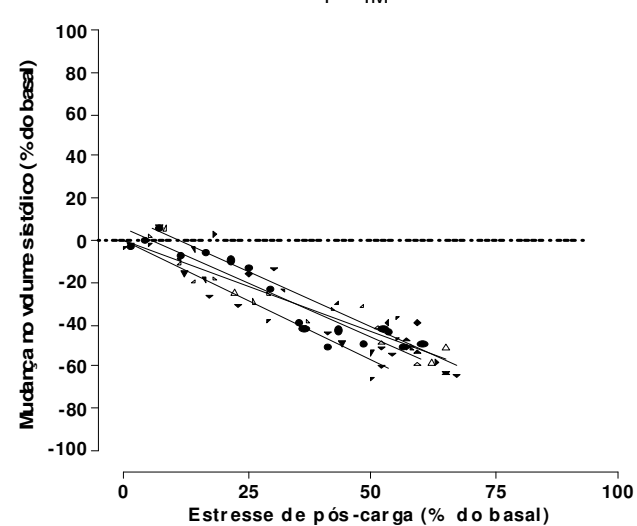

CMO - IM

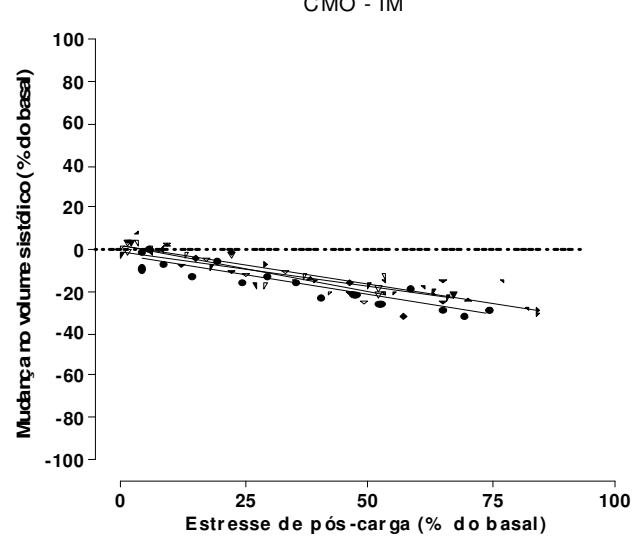

$M-I M$

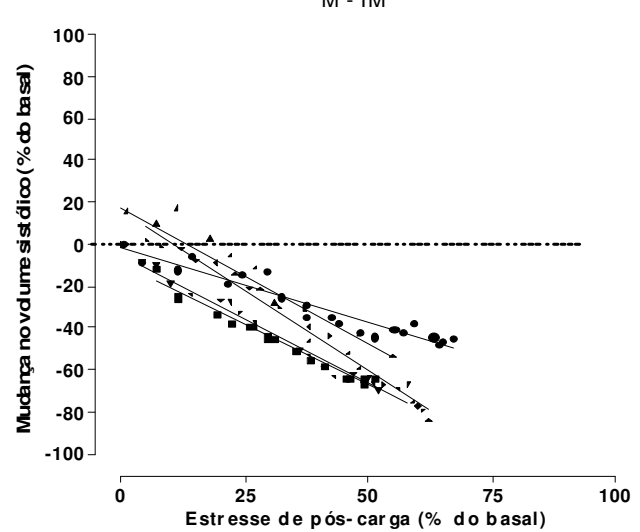

CMO - IV

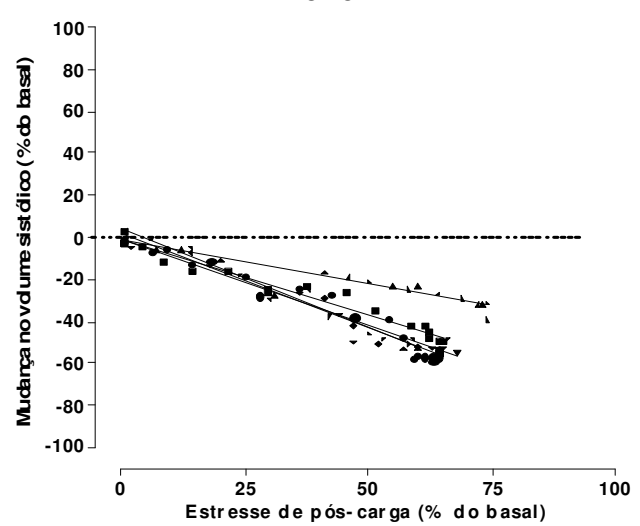

$\mathrm{CMO}+\mathrm{F}-\mathrm{IM}$

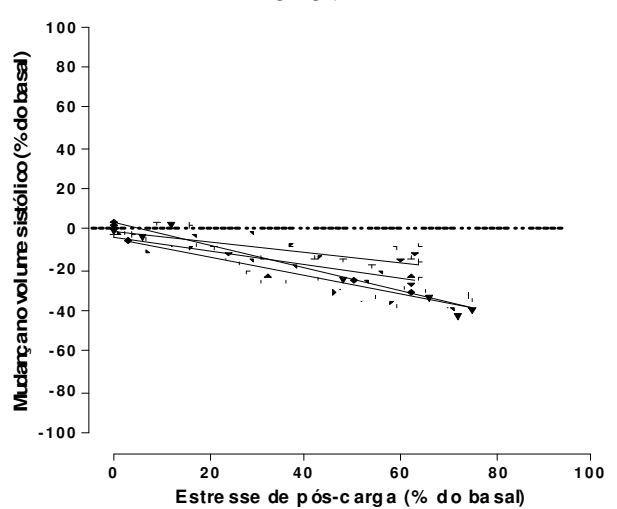

Figura 20a. Regressão linear da mudança no volume sistólico em função do aumento na pós-carga em cada animal. SHAM $(n=5)$, M-IM $(n=5)$, F-IM $(n=4)$, CMO-IV $(n=5)$, CMO-IM $(n=4)$ e CMO+FIM $(n=4)$ indicam, respectivamente, os grupos: meio de cultura injetado intramiocardicamente, fibrina injetada intramiocardicamente, CMO injetadas intravenosamente, CMO injetadas intramiocardicamente com meio de cultura e CMO injetadas intramiocardicamente com fibrina. 

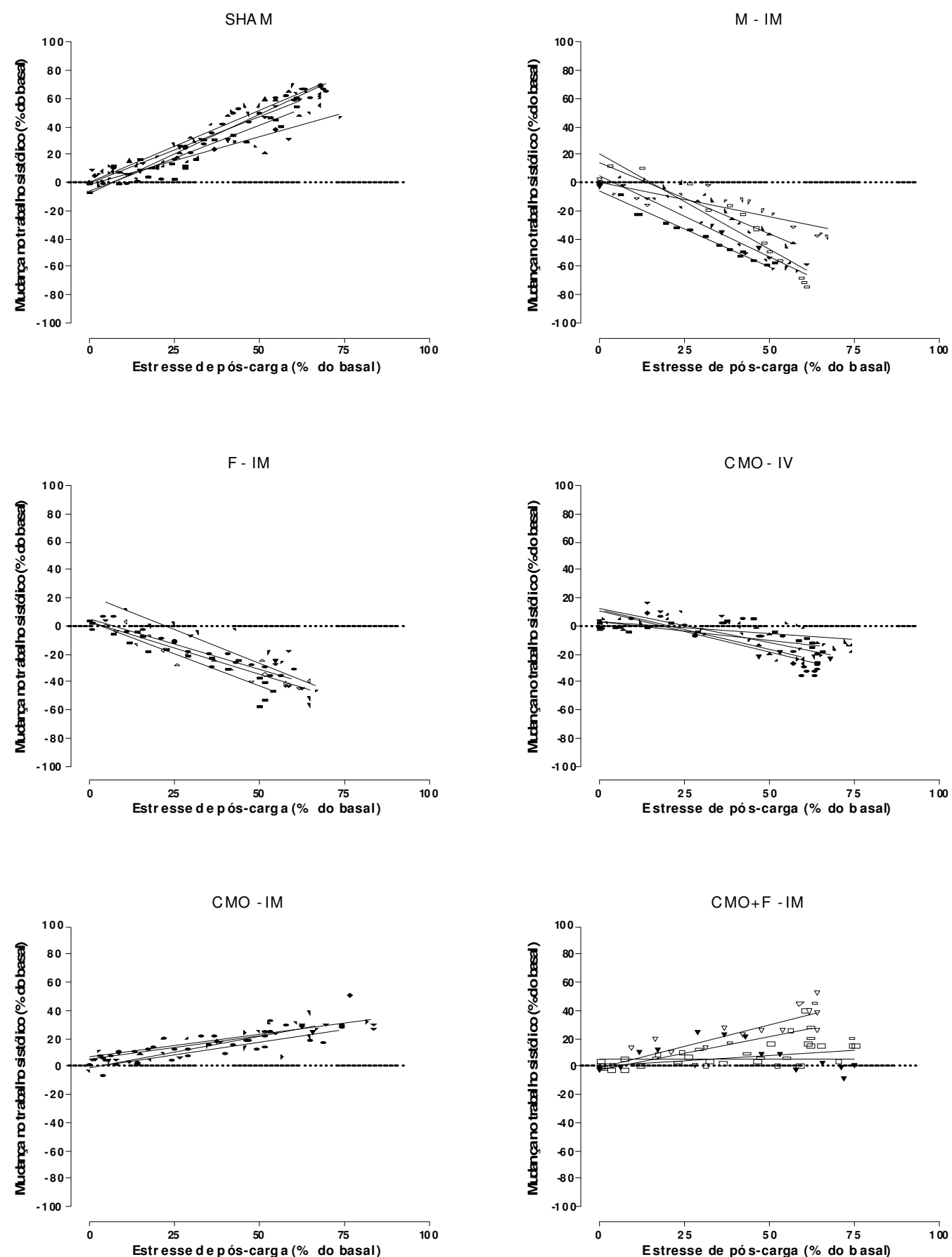

Figura 20b. Regressão linear da mudança na geração de trabalho sistólico em função do aumento na póscarga. As retas representam as regressões lineares das mudanças observadas no trabalho sistólico em função do aumento relativo da pós-carga em cada animal. SHAM (n = 5), M-IM (n = 5), F-IM $(n=4)$, CMO-IV ( $n=5)$, CMO-IM ( $n=4)$ e CMO+F-IM $(n=4)$ indicam, respectivamente, os grupos: meio de cultura injetado intramiocardicamente, fibrina injetada intramiocardicamente, CMO injetadas intravenosamente, $\mathrm{CMO}$ injetadas intramiocardicamente com meio de cultura e CMO injetadas intramiocardicamente 


\section{DISCUSSÃO}

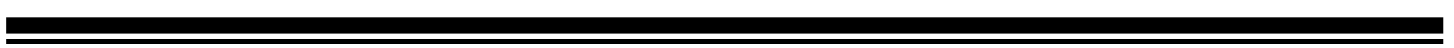


No presente estudo, nós avaliamos duas questões-chave relacionadas com a retenção cardíaca de células transplantadas: o momento ideal após o infarto do miocárdio para o transplante das células e a via de administração a ser empregada. Os dados sugerem que, sob as presentes condições experimentais, a retenção de CMO no coração é maior quando elas são injetadas diretamente no miocárdio, 7 dias após o infarto. Em contrapartida, para as vias IV, IC e ICO não há efeito do tempo após o infarto para a retenção cardíaca das células.

A via de administração de células IM foi a mais eficiente, ainda que insatisfatória, mas a utilização de polímero de fibrina como veículo resultou em um aumento de acúmulo das células transplantadas durante a injeção via IM, em animais injetados 24 horas após o infarto. Por tal razão, essa matriz injetável representa uma estratégia promissora para melhorar a enxertia das células transplantadas no miocárdio em procedimentos de terapia celular.

O tempo mais adequado para a terapia celular foi avaliado em estudos prévios que analisaram e compararam a eficiência da injeção de células realizada imediatamente após o infarto (cenário agudo) com àqueles realizados vários dias após o infarto (cenário crônico) ${ }^{54,55}$, porém nesses estudos, o tempo após infarto foi avaliado individualmente. No presente estudo avaliamos o acúmulo de células no coração de acordo com o tempo após o infarto no contexto de diferentes vias de administração. Esse desenho experimental possibilitou contemplar a questão que versa sobre os fatores que potencialmente influenciam na retenção das células transplantadas. A via de 
administração de células está diretamente relacionada nesse cenário dado que os processos que interceptam a estadia das células no órgão-alvo estão diretamente relacionados ao método empregado para o transplante de tais células. Assim, células adminstradas perifericamente dependem dos "sinais de homing" para migrarem e permanecerem no órgão sinalizador. Por outro lado, as células injetadas diretamente no local da lesão, em última análise, devem ficar retidas num primeiro momento; além disso, essas células estão sob influência direta do microambiente. Portanto, variações na quantidade de células retidas podem ser compreendidas de acordo com o método utilizado em seu emprego.

Nossos dados mostraram maior retenção cardíaca de CMO nos animais que receberam células injetadas diretamente no miocárdio, com destaque para àqueles cujas células foram transplantadas 7 dias após o infarto. Possivelmente, um dos fatores determinantes para esse maior número de células seja o microambiente mais favorável à permanência dessas células. Nesse período, o processo inflamatório progride para o término e já se inicia formação da cicatriz ${ }^{65 ; 35 ; 28}$. De fato, nas primeiras 72 horas após o infarto, o tecido isquêmico é um substrato extremamente desfavorável à presença de qualquer tipo celular que esteja participando do processo de reparo. Alta concentração de espécies reativas de oxigênio, debris celulares, células necróticas e apoptóticas, e massiva infiltração leucocitária perfazem esse ambiente. Análise do transcriptoma de coração infartado de ratos mostrou "up-regulation" de IL-6 e IL-8 nos primeiros três dias após a isquemia ${ }^{38}$. Células transplantadas nesse local tenderiam muito provavelmente à morte. Jiang e cols. (2008) demonstraram que células mesenquimais 
adminstradas uma semana após o infarto do miocárdio em ratos inibem a apoptose de cardiomiócitos residentes e melhoram a função cardíaca de ratos, comparadas às injetadas uma hora ou duas semanas após a isquemia ${ }^{66}$. Outro estudo observou melhora nos parâmetros histopatológicos de ratos infartados quando cardiomiócitos foram administrados duas semanas após o evento ${ }^{67}$. Similarmente, $\mathrm{Hu} \mathrm{X}$ e colaboradores (2007) determinaram maior presença de células mesenquimais da medula óssea quando administradas sete dias após o infarto ${ }^{68}$. Nesse estudo, o aumento de células correlacionou-se com aumento na angiogênese e diferenciação celular. Em todos os casos, os efeitos foram atribuídos à amenização do processo inflamatório nesse intervalo e, portanto, ao microambiente mais favorável à sobrevida das células transplantadas.

Nossos dados dos animais injetados intramiocardicamente após os três primeiros dias do infarto mostraram menores valores de retenção de células no coração e, portanto, apóiam hipótese da influência do processo inflamatório local através da criação de um microambiente hostil que inviabiliza a sobrevida das células enxertadas.

Considerando o efeito do microambiente isquêmico do coração infartado sobre as células transplantadas diretamente nesse órgão, diversos estudos têm sido realizados com o objetivo de testar o pré-condicionamento das células visando maior sucesso da sobrevida. Dentre os estímulos destacam-se a exposição prévia à hipóxia e choquetérmico ${ }^{69 ; 70}$.

Finalmente, a administração direta de células no miocárdio lesado por isquemia deve ser avaliada considerando a evolução do processo inflamatório de reparo do infarto. 
Nossos dados e de outros pesquisadores sugerem que possivelmente, o momento ideal para a injeção de células esteja localizado entre a finalização da formação do tecido granuloso rico em infiltrado inflamatório e a transição deste para o tecido de composição da cicatriz.

A respeito da retenção de células transplantadas nos diferentes tempos após o infarto pelas vias de administração "sistêmicas" - IV, IC e ICO - os dados mostraram um tendência de aumento de retenção quando as células foram administradas agudamente ao infarto. Essa observação vai ao encontro do conhecimento a respeito da mobilização e homing de células da medula ao coração após o infarto. Sabe-se que nas primeiras horas após a isquemia importantes mudanças no nível das principais quimiocinas e fatores quimioatrativos ocorrem $31 ; 34 ; 37,38$. Nesse contexto é possível compreender o papel das vias de administração sistêmicas. Embora os valores de retenção sejam demasiado baixos, nós observamos maiores níveis de retenção nas primeiras 72 horas para as vias IV, IC e ICO, comparados aos obtidos nos animais injetados sete dias após a isquemia.

Entretanto, um dos questionamentos a respeito dos baixos níveis de retenção encontrados nesse intervalo é sobre a natureza e intensidade da sinalização que governa os processos de mobilização e homing de células ao coração lesado. Possíveis explicações podem ser consideradas aqui.

Primeiramente, nós utilizamos células da medula óssea não-fracionadas, as quais representam um grupo particularmente heterogêneo de várias diferentes populações de 
células. Nesse sentido, é possível que a fração específica de células capazes de responder aos sinais de homing seja tão baixa que dificulte a detecção de forma confiável com a técnica empregada.

Segundo, embora várias citocinas e fatores de crescimento sejam superexpressos e liberados pelo coração lesado tão logo ocorra o infarto agudo do miocárdio, mais tempo pode ser requerido para que o cenário completo de moléculas e gradientes necessários para que o processo de homing funcione efetivamente. Além disso, considerando que as células são obtidas de animais doadores saudáveis, talvez elas necessitem ser estimuladas por fatores presentes no receptor infartado, tornando-as capazes de responder aos sinais de homing ${ }^{56}$.

Em terceiro, os fatores que governam o recrutamento de células para processos reparativos podem também governar a resposta inflamatória aguda, então as células recrutadas podem deparar com um microambiente particularmente hostil que pode prejudicar sua sobrevida e permanência no tecido durante os primeiros dias após a lesão.

Finalmente, o processo de homing per se pode ser ineficiente, a despeito do tempo que se segue à injúria e qualquer outra variável.

Notavelmente, os dados do presente estudo puderam prover evidências adicionais sobre o limitado acúmulo cardíaco e a ampla distribuição das células transplantadas, não apenas para o momento após o IAM para a terapia, mas principalmente para a via de 
administração empregada. A via de administração IM foi a mais eficiente em termos de retenção cardíaca de células, porém ainda extremamente insatisfatória considerando que as células são transplantadas diretamente no estroma do órgão-alvo.

Vários mecanismos de perda de células podem influenciar a permanência dessas células no órgão-alvo, incluindo problemas técnicos associados com a via de administração, o fluxo passivo através do sistema vascular coronariano e linfático e a morte celular 17;27;54:57,58. Esses mecanismos podem também explicar a grande variabilidade dos resultados observados no grupo da via IM, um fato previamente reportado por Hou e colaboradores ${ }^{59}$. Conjuntamente, os achados acima mencionados impulsionaram-nos a buscar estratégias que objetivassem melhorar a retenção e sobrevida das células transplantadas.

O polímero de fibrina é uma matriz estrutural biodegradável importante para a cicatrização de tecidos lesados e tem sido demonstrado que ele melhora a sobrevida das células transplantadas, induz a angiogênese, reduz a extensão da área de infarto e preserva a função cardíaca após o infarto do miocárdio ${ }^{49-51 ; 71}$. Entretanto, até o momento, não há estudo que tenha avaliado especificamente a capacidade de retenção dessa matriz injetável. Aqui, nós demonstramos que o polímero de fibrina aumentou mais que duas vezes a quantidade de células transplantadas que permaneceram após a injeção via IM. 
Além disso, confirmamos esses dados mediante avaliação histológica. Em adição, verificamos a permanência das células transplantadas 30 dias após o implante, indicando que a matriz não compromete ou prejudica a sobrevida das células nem dos animais.

Existem, entretanto, limitações que devem ser mencionadas aqui.

A correção dos valores de radioatividade no coração, de acordo com a taxa de extrusão do $\left[{ }^{99 \mathrm{~m}} \mathrm{Tc}\right]$ tecnécio das $\mathrm{CMO}$, poderia introduzir alguns vieses. Para abordar essa questão, nós validamos a correção e mostramos que o [ $\left.{ }^{99 \mathrm{~m}} \mathrm{Tc}\right]$ tecnécio extruído foi quase completamente eliminado do coração e, então, os valores de radioatividade puderam ser atribuídos às CMO marcadas. Ademais, o experimento de validação foi realizado injetando-se um volume preciso de sobrenadante, onde um número correspondente de CMO foi incubado por 24 horas. Isto é importante devido ao fato de que a quantidade exata de radiofármaco extruído das CMO marcadas foi utilizada. Assim, pudemos recapitular o que provavelmente teria ocorrido com o composto extruído das CMO injetadas.

Cabe destacar que a extrusão de $\left[{ }^{99 \mathrm{~m}} \mathrm{Tc}\right]$ de células já foi observada em células não-linfóides. Num estudo em que o ${ }^{99 \mathrm{~m}} \mathrm{Tc}-\mathrm{HMPAO}$ foi utilizado para marcar células endoteliais foi detectada a extrusão de cerca $60 \%$ do radiofármaco 20 horas após a marcação e correções devidas nos valores de radioatividade foram realizadas ${ }^{72}$. 
A análise do sobrenadante por cromatografia revelou que o $\left[{ }^{99 \mathrm{~m}} \mathrm{Tc}\right]$ tecnécio extruído é uma mistura de espécies radioquímicas, as quais são diferentes daquela utilizada para marcar as células. Além disso, foi previamente demonstrado que a injeção via IV de ${ }^{99 \mathrm{~m}} \mathrm{Tc}-\mathrm{HMPAO}$, o qual é um complexo que marca preferencialmente leucócitos, não resulta em qualquer marcação significativa no miocárdio ${ }^{60}$. Então, cuidados especiais foram tomados para minimizar as chances de que a correção dos valores de radioatividade pudesse influenciar nos resultados relatados aqui.

Adicionalmente, é importante ressaltar o mecanismo de extrusão do radiofármaco (mecanismo ativo, através de uma bomba de cálcio) não esteve relacionado à citotoxicidade ou morte das CMO. Nossos dados mostraram que a integridade da membrana celular não foi afetada com a marcação e que, portanto, o tecnécio extruído não era produto da morte e ruptura da membrana citoplasmática. Também não observamos incremento na apoptose após a radiomarcação. As CMO marcadas foram mantidas em cultura e a população mesenquimal presente nesse pool aderiu em placas mostrando que não houve alteração funcional dessas células. Recentemente um estudo demonstrou que o complexo ${ }^{99 \mathrm{~m}} \mathrm{Tc}-\mathrm{HMPAO}$ pode ser usado seguramente para marcação de células endoteliais com o propósito de quantificar a retenção dessas células ${ }^{72}$.

O cerne da questão que versa sobre a retenção relativa de células no órgão-alvo em protocolos de terapia celular é a implicação no restauro/restabelecimento funcional do órgão, particularmente quando se consideram os efeitos favoráveis dependentes da 
ação local dessas células, de maneira direta ou indireta. Nós avaliamos a função cardíaca de animais infartados em que as CMO foram adminstradas intravenosamente ou intramiocardicamente (com e sem fibrina associada às células), através da análise de parâmetros hemodinâmicos dos animais durante o estresse de pós-carga com o uso de um vasoconstritor. Nossos resultados mostraram que o desempenho cardíaco foi melhor nos animais injetados intramiocardicamente, cuja retenção de células no coração era maior. Os animais que receberam CMO por via intravenosa comportaram-se nesse sentido, similarmente aos animais infartados nos quais não foi realizado emprego de fonte exógena de células, mostrando que a presença e a quantidade local de CMO contribuem para um melhor desfecho, em termos funcionais, da lesão cardíaca por isquemia. Adicionalmente, a avaliação histopatológica dos corações mostrou melhora nos parâmetros relacionados ao remodelamento (aumento na espessura da cicatriz, da zona de borda do infarto e diminuição do perímetro do ventrículo esquerdo) apenas nos animais injetados intramiocardicamente.

Embora nossos resultados tenham falhado em mostrar melhora da função cardíaca nos animais em que as CMO foram administradas intravenosamente, outros estudos obtiveram êxito através da administração de células por essa via ${ }^{73-75}$.

Razões para a inconsistência entre os resultados observados por nós e por esses autores incluem (1) o modelo animal utilizado, (2) a quantidade de células administradas e (3) o tipo celular. No estudo de Wolf e Halkos foram utilizados porcos infartados, nos quais foram administradas crescentes doses de células mesenquimais da medula óssea (até $10 \times 10^{6}$ células $/ \mathrm{kg}$ peso corpóreo); os efeitos benéficos sobre a função cardíaca 
foram observados nos animais injetados com o maior número de células. No estudo do grupo de Yoshitaka Iso, foram utilizados camundongos e foram administradas células mesenquimais da medula óssea numa proporção cerca de 10 vezes maior ao que foi administrada em nosso estudo. Além disso, esses camundongos foram tratados com injeções semanais durante três semanas, otimizando a disponibilização de células para o sistema. Nós utilizamos um pool de células da medula óssea que contém apenas uma pequena fração de células mesenquimais e outras populações "tronco". Além disso, em nosso protocolo empregamos $1 \times 10^{6} \mathrm{CMO}$ por animal.

Assim, pode-se sugerir que o tipo celular e a quantidade de células empregadas são relevantes para os resultados da terapia com células.

É importante salientar a condição fisiológica em que os animais foram avaliados. Os estudos de terapia celular para cardiopatias avaliam, de maneira geral, os animais em condição basal do ponto de vista fisiológico Recentemente foi demonstrado que célulastronco mesenquimais da medula óssea, apesar de ficarem retidas no coração, falharam em melhorar a função cardíaca de ratos infartados quando injetadas sistêmica ou diretamente no miocárdio ${ }^{76}$.

Aqui nós consideramos medidas hemodinâmicas dos animais no estado basal e no contexto de aumento súbito da pressão. Essa abordagem permitiu o exame da real capacidade funcional, especialmente do ponto de vista contrátil, dos animais de cada grupo experimental estudado, visto que todos os animais estudados, independentemente do grupo experimental, apresentaram parâmetros hemodinâmicos similares no estado 
basal. Quando os mesmos animais foram avaliados na condição de aumento súbito na pós-carga, apenas os animais que receberam as células diretamente no miocárdio tiveram comportamento similar ao dos animais sadios (não-infartados), ou seja, tiveram um desempenho cardíaco satisfatório.

As hipóteses que podem explicar os efeitos benéficos observados nesse estudo com o uso de células da medula óssea no infarto envolvem diferentes mecanismos.

A ação direta dessas células, ou seja, diferenciação, transdiferenciação ou fusão com células cardíacas residentes podem ser considerados efetores. Embora não tenhamos realizado estudo histológico para identificação direta das células injetadas no coração, resultados de nosso laboratório com outro tipo celular mostrou que as células permanecem no tecido, com ou sem o uso de fibrina, após 30 dias da injeção. Por outro lado, não se sabe se os efeitos, sejam de qual natureza forem, ocorrem nos momentos iniciais à injeção ou mais tardiamente. O grupo de Anversa tem demonstrado que uma população específica de células da medula óssea $\left(\mathrm{c}-\mathrm{kit}^{+} / \mathrm{lin} / \mathrm{Sca}-1^{+}\right)$adquire fenótipo de cardiomiócitos repovoando a região infartada. Porém muitos autores discordam desse evento e, além disso, não têm conseguido reproduzir os resultados encontrados pelo grupo liderado por Anversa ${ }^{15 ; 16}$.

Há, por outro lado, uma corrente que defende o envolvimento da ação parácrina de diferentes tipos celulares já testados ${ }^{41 ; 64 ; 77}$. As células injetadas secretariam fatores anti-apoptóticos, pró-angiogênicos, fatores de crescimento que, numa ação coordenada e 
complexa, minimizariam a morte de células cardíacas isquêmicas, promoveriam a neoangiogênese, modulação do processo inflamatório local, entre outros efeitos ${ }^{78 ; 79}$.

Resultados obtidos em nosso laboratório por Gonçalves e colaboradores (dados não publicados) mostraram que o incremento de VEGF no coração, através do uso células como vetores para a expressão do fator, também promove melhor desempenho cardíaco em animais infartados.

Os resultados da avaliação histológica do presente estudo sugerem que, embora os animais de todos os grupos experimentais tenham tido tamanho de infarto muito similar, a composição da cicatriz fibrótica e suas consequiências sobre o remodelamento pós o IAM podem ter contribuído positivamente para o desempenho cardíaco desses animais. As medidas de espessura de cicatriz e zona de borda do infarto, observadas nos animais tratados com CMO por via intramiocárdica, podem sugerir que houve um "fortalecimento" da cicatriz, fato que poderia minimizar os efeitos da fibrose sobre a contratilidade cardíaca, além da possibilidade da ação das CMO na região remota ao infarto, visto que a dilatação da cavidade do ventrículo esquerdo foi menor nos animais que receberam CMO via intramiocárdica. Somados, a importância desses parâmetros de remodelamento pós-IAM para a função ventricular merecem destaque no que diz respeito aos efeitos da terapia com $\mathrm{CMO}$.

É importante salientar que o fato de não termos observado diferença com relação ao tamanho de infarto entre os grupos pode ser explicado pelo fato de que os animais foram previamente selecionados através de ecocardiografia, a fim de se evitar viés de 
interpretação, considerando que a função cardíaca está diretamente relacionada ao infarto.

Nesse estudo nós mostramos melhora nos parâmetros cardíacos funcionais e histopatológicos dos animais injetados intramiocardicamente, porém, o incremento de células com o uso do polímero de fibrina, não resultou em melhora adicional. Um razão para essa falta de incremento na resposta pode estar relacionada ao tempo após infarto em que os animais foram avaliados. Alguns autores mostraram efeitos em longo prazo de células-tronco empregadas em animais infartados ${ }^{80-81}$. No estudo de Lian, os animais foram avaliados até 12 meses e a função cardíaca melhorou progressivamente até o sexto mês após a injeção de células.

Nesse sentido, nos animais do presente estudo, em que as CMO foram injetadas diretamente no coração, ainda que tenham tido um desempenho cardíaco similar no momento em que foram avaliados, podem evoluir de maneira diferente, considerando que a resolução completada do infarto se dá além do período de 30 dias.

Em conjunto, esses resultados indicam que a retenção de células da medula óssea no coração é maior quando as células são injetadas diretamente no miocárdio de ratos, e que a administração aos sete dias após o infarto favorece ainda mais a retenção dessas células. Por outro lado, a retenção de CMO no coração é bastante reduzida (cerca de 0,5 $\%$ do total injetado) quando as vias de administração IV, IC e ICO são utilizadas independentemente do tempo após o infarto para o transplante. Além disso, o acúmulo das células transplantadas 24 horas após a isquemia pode ser significativamente 
melhorado através da utilização de polímero de fibrina como veículo das células durante a injeção via IM. Finalmente, nos animais cuja retenção de células no coração foi maior, ou seja, naqueles em que as células foram injetadas diretamente no miocárdio (CMO IM e CMO+F - IM), constatamos melhor desempenho cardíaco frente à sobrecarga pressórica. 
CONCLUSÕES 
Com base nos achados descritos, podemos concluir sumariamente:

- A retenção cardíaca de CMO é maior quando essas células são administradas diretamente no miocárdio;

- A retenção de CMO no coração é maior quando a injeção IM é realizada 7 dias após o IAM;

- O perfil de biodistribuição das CMO é similar em todos os grupos, independentemente do tempo após a isquemia cardíaca e da via de administração utilizada, porém nos animais injetados agudamente ao IAM (1-3 dias) há um acúmulo maior de células nos órgãos estudos comparados aos animais injetados aos 7 dias após o IAM;

- A associação do biopolímero de fibrina como veículo para a injeção das CMO incrementou significativamente a retenção dessas células (de $~ 7$ para 17\%);

- As células injetadas com fibrina sobrevivem e permanecem no tecido cardíaco até 30 dias após o transplante; 
- Em ratos infartados, a injeção intramiocárdica de CMO atenua o remodelamento ventricular, minimizando a dilatação da cavidade do VE e promovendo o aumento na espessura da parede infartada do ventrículo;

- O desempenho cardíaco dos animais infartados frente ao aumento súbito da pressão foi satisfatório apenas nos animais em que as CMO foram injetadas diretamente no miocárdio. 


\section{PERSPECTIVAS}

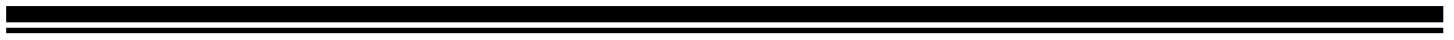


Nesse estudo, um dos principais achados foi a diferença na retenção cardíaca de células da medula óssea de acordo com a via de administração das células e o tempo após o infarto. Além disso, nós demonstramos que o desempenho cardíaco dos ratos infartados durante o estresse de pós-carga é melhor apenas quando esses animais são tratados com CMO intramiocardicamente, sugerindo que a quantidade de células-tronco locais é importante para o restabelecimento da função cardíaca após o infarto.

O uso de fibrina durante a injeção melhorou a retenção cardíaca das células, porém, do ponto de vista funcional, o incremento de células com o polímero não exerceu efeito superior ao constatado nos animais em que as CMO foram intramiocardicamente em veículo aquoso.

Com base nesses resultados apresentados, merecem investigação futura os pontos sumarizados abaixo. Quais sejam:

- Avaliação em longo prazo da função cardíaca e sobrevida dos animais infartados em que as CMO forem injetadas intramiocardicamente com fibrina ou com veículo aquoso;

- Mecanismo de ação das CMO no contexto do infarto com o uso do biopolímero e na ausência dele; 
- Efeito da presença das CMO e do polímero de fibrina sobre a resposta inflamatória subseqüente à isquemia;

- Tempo de degradação da matriz de fibrina no tecido cardíaco após sua administração. 
REFERÊNCIAS BIBLIOGRÁFICAS

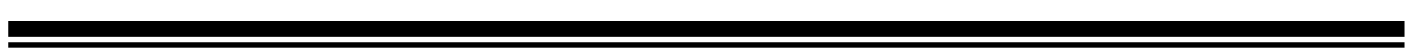


1. Lenfant C. NHLBI at 50: reflections on a half-century of research on the heart, lungs, and blood. National Heart, Lung, and Blood Institute, Interview by Charles Marwick. JAMA 1998;280(24):2062-4.

2. Reinlib L, Field L. Cell transplantation as future therapy for cardiovascular disease? A workshop of the National Heart, Lung, and Blood Institute. Circulation 2000; 101(18):182-7.

3. Melo LG, Pachori AS, Kong D, Gnecchi M, Wang K, Pratt RE, Dzau VJ. Molecular and cell-based therapies for protection, rescue, and repair of ischemic myocardium. Circulation 2004; 109:2386-2393.

4. Collins SD, Baffour R, Waksman R. Cell therapy in myocardial infarction. Cardiovasc Revasc Med. 2007; 8:43-51.

5. Orlic D, Kajstura J, Chimenti S, Jakoniuk I, Anderson SM, Li B, Pickel J, McKay R, Nadal-Ginardi B, Bodine DM, Leri A, Anversa P. Bone marrow cells regenerate infarcted myocardium. Nature 2001;410:701-705.

6. Orlic D, Kajstura J, Chimenti S, Limana F, Jakoniuk I,Quaini F, e cols. Mobilized bone marrow cells repair the infarcted heart, improving function and survival. Proc Natl Acad Sci USA. 2001;98:10344-9.

7. Tomita S, Li RK, Weisel RD, Mickle DA, Kim EJ, Sakai T, Jia ZQ. Autologus transplantation of bone marrow cells improves damaged heart function. Circulation 1999;100:II247-II56. 
8. Toma C, Pittenger MF, Reinhardt RL, e cols. Human mesenchymal stem cells differentiate to a cardiomyocyte phenotype in the adult murine heart. Circulation 2002;105:93-98.

9. Kudo M, Wang Y, Wani MA, Xu M, Ayub A, Ashraf M. Implantation of bone marrow stem cells reduces the infarction and fibrosis in ischemic mouse heart. $\mathrm{J}$ of Molec and Cellular Cardiol. 2003;35:1113-1119.

10. Assmus B, Schachinger V, Teupe C, Britten M, Lehmann R, Dobert N, Grunwald F, Aicher A, Urbich C, Martin H, Hoelzer D, Dimmeler S, Zeiher AM. Transplantation of progenitor cells and regeneration enhancement in acute myocardial infarction (TOPCARE-AMI). Circulation 2002; 106(24):3009-17.

11. Menasche P, Hagege AA, Scorsin M, Pouzet B, Desnos M, Duboc D, Schwartz K, Vilquin JT, Marolleau. Myoblast transplantation for heart failure. Lancet 2001

12. Kang HJ, Kim HS, Zhang SY, Park KW, Cho HJ, Koo BK, Kim YJ, Soo Lee D, Sohn DW, Han KS, Oh BH, Lee MM, Park YB. Effects of intracoronary infusion of peripheral blood stem-cells mobilized with granulocyte-colony-stimulating factor on left ventricular system function and restenosis after coronary stenting in myocardial infarction: the MAGIC cell randomized clinical trial. Lancet 2004;363:751-6.

13. Meyer GP, Wollert KC, Lotz J, Steffens J, Lippolt P, Fichtner S, Hecker H, Schaefer A, Arseniev L, hertenstein B, Ganser A, Drexler H. Intracoronary bone marrow cell transfer after myocardial infarction; eighteen months's follow-up data from the randomized, controlled, BOOST (bone marrow transfer to enhance ST-elevation infarcted regeneration) trial. Circulation 2006,113:1287-94. 
14. Makino S, Fukuda K, Miyoshi S, Konishi F, Kodama H, Pan J, e cols. Cardiomyocytes can be generated from marrow stromal cells in vitro. J Clin Invest. 1999; 103:697-705.

15. Murry CE, Soonpaa MH, Reinecke H, Nakajima H, Nakajima HO, Rubart M, Pasumarthi KBS, Virag JI, Bartelmez SH, Poopa V, Bradford G, Dowell JD, Williams DA, Field LJ. Haematopoietic stem cells do not transdifferentiate into cardiac myocytes in myocardial infarcts. Nature 2004;02466:1-5.

16. Balsam LB, Wagers AJ, Cristensen JL, Kofidis T, Weissman IL, Robbins RC. Haematopoietic stem cells adopt mature haematopoietic fates in ischaemic myocardium. Nature 2004;02460:1-6.

17. Müller-Ehmsen J, Whittaker P, Kloner RA, Dow JS, Sakoda T, Long TI, Laird PW, Kedes L. Survival and development of neonatal rat cardiomyocytes transplanted into adult myocardium. J Mol Cell Cardiol.2002;34(2):107-16.

18. Menasche P, Hagege AA, Vilquin JT, Desnos M, Abergel E, Pouzet B, Bel A, Sarateanu S, Scorsin M, Schwartz K, Bruneval P, Benbunan M, Marolleau JP, Duboc D. Autologous skeletal myoblast transplantation for severe post-infarction left ventricular dysfunction. J Am Coll Cardiol. 2003;41(7):1078-83.

19. Miyahara Y, Nagaya N, Kataoka M, Yanagawa B, Tanaka K, Hao H, Ishino K, Ishida H, Shimizu T, Kangawa K, Sano S, Okano T, Kitamura S, Mori H. Monolayered mesenchymal stem cells repair scarred myocardium after myocardial infarction. Nature Med. 2006; 12 (4): 459-465.

20. Morrison SJ, Uchida N, Weissman IL. The biology of hematopoietic stem cells. Annu Rev Cell Dev Biol. 1995;11:35-71. 
21. Lapidot T, Petit I. Current understanding of stem cell mobilization: the roles of chemokines, proteolytic enzymes, adhesion molecules, cytokines, and stromal cells. Exp Hematol. 2002;30(9):973-81.

22. Kucia M, Dawn B, Hunt G, Guo Y, Wysoczynski M, Majka M, Ratajczak J, Rezzoug F, Ildstad ST, Bolli R, Ratajczak MZ. Cells expressing early cardiac markers reside in the bone marrow and are mobilized into the peripheral blood after myocardial infarction. Circ Res. 2004;95(12):1191-9.

23. Kucia M, Ratajczak J, Reca R, Janowska-Wieczorek A, Ratajczak MZ. Tissuespecific muscle, neural and liver stem/progenitor cells resid in the bone marrow, respond to an SDF-1 gradient and are mobilized into peripheral blood during stress and tissue injury. Blood cells, Molecules and Diseases 2003;32:52-57.

24. Morel F, Szilvassy SJ, Travis M, Chen B, Galy. A Primitive hematopoietic cell in murine bone marrow expresses the CD34 antigen. Blood. 1996;88(10):377484.

25. Yin $\mathrm{T}$ and $\mathrm{Li} \mathrm{L}$. The stem cell niches in bone. J Clin Invest. 2006;116(5):1195201.

26. Jackson KA, Majka SM, Wang H, Pocius J, Hartley CJ, Majesky MW, Entman ML, Michael LH, Hirschi KK, Goodell MA. Regeneration of ischemic cardiac muscle and vascular endothelium by adult stem cells. J Clin Invest. 2001;107(11):1395-402.

27. Dow J, Simkhovich BZ, Kedes L, Kloner RA. Washout of transplanted cells from the heart: A potential new hurdle for cell transplantation therapy. Cardiovasc Res. 2005; 67:301-307. 
28. Frangogiannis NG, Smith CW, Entman ML. The inflammatory response in myocardial infarction. Cardiovasc Res. 2002;53(1):31-47.

29. Lefer DJ, Granger DN. Oxidative stress and cardiac disease. Am J Med. 2000;109(4):315-23.

30. Granger DN. Role of xanthine oxidase and granulocytes in ischemia-reperfusion injury. Am J Physiol. 1988;6(2):H1269-H1275.

31. Vandervelde S, Van-Luyn MJA, Tio RA, Harmsen MC. Signaling factors in stem cell-mediated repair of infarcted myocardium. J Mol Cell Cardiol. 2005; 39:363-376.

32. Vandervelde S, Van Luyn MJ, Rozenbaum MH, Petersen AH, Tio RA, Harmsen MC. Stem cell-related cardiac gene expression early after murine myocardial infarction. Cardiovasc Res. 2006;73(4):783-93.

33. Shintani S, Murohara T, Ikeda H, Ueno T, Honma T, Katoh A, Sasaki K, Shimada T, Oike Y, Imaizumi T. Mobilization of endothelial progenitor cells in patients with acute myocardial infarction. Circulation 2001;103(23):2776-9.

34. Abbott JD, Huang Y, Liu D, Hickey R, Krause D, Giordano FJ. Stromal cellderived factor-1 alfa plays a critical role in stem cell recruitment to the heart after myocardial infarction but is not sufficient to induce homing in the absence of injury. Circulation 2004; 110:3300-3305.

35. Lu L, Zhang JQ, Ramires FJ, Sun Y. Molecular and cellular events at the site of myocardial infarction: from the perspective of rebuilding myocardial tissue. Biochem Biophys Res Commun. 2004;320(3):907-13. 
36. Gill M, Dias S, Hattori K, Rivera ML, Hicklin D, Witte L, Girardi L, Yurt R, Himel H, Rafii S. Vascular trauma induces rapid but transient mobilization of VEGFR2(+)AC133(+) endothelial precursor cells. Circ Res. 2001;88(2):167-74.

37. Askari AT, Unzek S, Popovic ZB, Goldman CK, Forudi F, Kiedrowski M, Rovner A, Ellis SG, Thomas JD, DiCorleto PE, Topol EJ, Penn MS. Effect of stromal-cell-derived factor 1 on stem-cell homing and tissue regeneration in ischemic cardiomyopathy. Lancet 2003; 362:679-703.

38. Roy S, Khanna S, Kuhn DE, Rink C, Williams WT, Zweier JL, Sen CK. Transcriptome analysis of the ischemia-reperfused remodeling myocardium: temporal changes in inflammation and extracellular matrix. Physiol Genomics. 2006; 25(3):364-74.

39. Hodgson DM, Behfar A, Zingman LV, Kane GC, Perez-Terzic C, Alekseev AE, Puceat M, Terzic A. Stable benefit of embryonic stem cell therapy in myocardial infarction. Am J Physiol Heart Circ Physiol. 2004; 287(2):471-9.

40. Olivares EL, Ribeiro VP, Werneck de Castro JP, Ribeiro KC, Mattos EC, Goldenberg RC, Mill JG, Dohmann HF, dos Santos RR, de Carvalho AC, Masuda MO. Bone marrow stromal cells improve cardiac performance in healed infarcted rat hearts. Am J Physiol Heart Circ Physiol. 2004; 287(2):464-70.

41. Liu Y, Guo J, Zhang P, Zhang S, Chen P, Ma K, Zhou C. Bone marrow mononuclear cell transplantation into heart elevates the expression of angiogenic factors. Microvasc Res. 2004; 68(3):156-60.

42. Chin BB, Nakamoto Y, Butle JW, Pittenger MF, Wahl R, Kraitchman DL. ${ }^{111}$ Inoxine labelled mesenchymal stem cell SPECT after intravenous administration in myocardial infarction. Nucl Med Commun 2003; 24 (11):1149-54. 
43. Aicher A, Brenner W, Zuhayra M, Badorff C, Massoudi S, Assmus B, Eckey T, Henze E, Zeiher AM, Dimmeler S. Assessment of the tissue distribution of transplanted human endothelial progenitor cells by radioactivity labeling. Circulation 2003; 107:2134-2139.

44. Schuster MD, Kocher AA, Seki T, Martens TP, Xiang G, Homma S, Itescu S. Myocardial neovascularization by bone marrow angioblasts results in cardiomyocyte regeneration. Am J Physiol Heart Circ Physiol. 2004; 287(2):52532.

45. Strauer BE, Brehm M, Zeus T, Köstering M, Hernandez A, Sorg RV, Kögler G, Wernet P. Repair of infarcted myocardium by autologous intracoronary mononuclear bone marrow cells transplantation in humans. Circulation 2002; 106:1913-1918.

46. Perin EC, Dohmann HF, Borojevic R, Silva SA, Sousa AL, Mesquita CT, Rossi MI, Carvalho AC, Dutra HS, Dohmann HJ, Silva GV, Belem L, Vivacqua R, Rangel FO, Esporcatte R, Geng YJ, Vaughn WK, Assad JA, Mesquita ET, Willerson JT. Transendocardial autologous bone marrow cell transplantation for severe, chronic ischemic heart failure. Circulation 2003; 107(18):2294-302.

47. Tse HF, Kwong YL, Chan JK, Lo G, Ho CL, Lau CP. Angiogenesis in ischaemic myocardium by intramyocardial autologous bone marrow mononuclear cell implantation. Lancet 2003; 361(9351):47-9.

48. Radosevich M, Goubran HA, Burnouf T. Fibrin sealant: scientific rationale, production methods, properties, and current clinical use. Vox Sanguinis 1997; 72:133-143. 
49. Christman KL, Vardanian AJ, Fang Q, Sievers RE, Fok, HH, Lee RJ. Injectable fibrin scaffold improves cell transplantat survival, reduces infarct expansion, and induces neovasculature formation in ischemic myocardium. J Am Coll Cardiol. 2004; 44:654-60.

50. Christman KL, Fok HH, Sievers RE, Fang Q, Lee RJ. Fibrin glue alone and skeletal myoblast in fibrin scaffold preserve cardiac function after myocardial infarction. Tissue Engineering 2004; 10 (3/4):403-409.

51. Huang NF, Yu J, Sievers R, Li S, Lee RJ. Injectable biopolymers enhance angiogenesis after myocardial infarction. Tissue Engineering 2005; 11 (11/12):1860-1866.

52. Ceretec $®$ product monograph. Little Chalfont -Buckinghamshire: Amersham plc.

53. Brown RP, Delp MD, Lindstedt SL, Rhomberg LR, Beliles RP. Physiological parameter values for physiologically based pharmacokinetic models. Toxicol Ind Health 1997; 13:407-484.

54. Zhang M, Methot D, Poppa V, Fujio Y, Walsh K, Murry CE. Cardiomyocyte grafting for cardiac repair: graft cell death and anti-death strategies. J Mol Cell Cardiol. 2001; 33(5):907-21.

55. Barbash IM, Chouraqui P, Baron J, Feinberg MS, Etzion S, Tessone A, Miller L, Guetta E, Zipori D, Kedes LH, Kloner RA, Leor J. Systemic delivery of bone marrow-derived mesenchymal stem cells to the infarcted myocardium: feasibility, cell migration, and body distribution. Circulation 2003; 108(7):863-8.

56. Lapidot T, Dar A, Kollet O. How do stem cells find their way home? Blood 2005;106(6):1901-1910. 
57. Suzuki K, Murtuza B, Beauchamp JR, Smolenski RT, Varela-Carver A, Fukushima S, Coppen SR, Partridge TA, Yacoub MH. Dynamics and mediators of acute graft attrition after myoblast transplantation to the heart. FASEB J. 2004; 18(10):1153-5.

58. Yasuda T, Weisel RD, Kiani C, Mickle DA, Maganti M, Li RK. Quantitative analysis of survival of transplanted smooth muscle cells with real-time polymerase chain reaction. J Thorac Cardiovasc Surg. 2005; 129(4):904-11.

59. Hou D, Youssef EA, Brinton TJ, Zhang P, Rogers P, Price ET, Yeung AC, Johnstone BH, Yock PG, March KL. Radiolabeled cell distribution after intramyocardial, intracoronary, and interstitial retrograde coronary venous delivery. Circulation 2005;112(suppl I):I150-I156.

60. Neirinckx RD, Canning LR, Piper IM, Nowotnik DP, Pickett RD, Holmes RA, Volkert WA, Forster AM, Weisner PS, Marriott JA, Chaplin SB. Technetium99m d,1-HM-PAO: a new radiopharmaceutical for SPECT imaging of regional cerebral blood perfusion. J Nucl Med. 1987; 28(2):191-202.

61. Kajstura J, Rota M, Whang B, Caspera S, Hosoda T, Bearzi C, Nurzynska D, Kasahara H, Zias E, Bonafé M, Nadal-Ginardi B, Torella D, Nascimbene A, Quaini F, Urbanek K, Leri A, Anversa P. Bone marrow cells differentiate in cardiac cell lineages after infarction independently of cell fusion. Circ Res. 2005; 96:127-137.

62. Rota M, Kajstura J, Hosoda T, Bearzi C, Vitale S, Esposito G, Iaffaldano G, Padin-Iruegas, Gonzales A, Rizzi R, Small N, Muraski J, Alvarez R, Chen X, Urbanek K, Bolli R, Houser S, Leri A, Sussman MA, Anversa P. Bone marrow cells adopt the cardiomyogenic fate in vivo. PNAS 2007;104 (45):17783-17788. 
63. Amado LC, Saliaris AP, Shuleri KH, John M, Xie J, Cattaneo S, Durand DJ, Fitton T, Kuang JQ, Stewart G, Lehrke S, Baumgartner WW, Martin BJ, Heldman AW, Hare JM. Cardiac repair with intramyocardial injection of allogenic mesenchymal stem cells after myocardial infarction. PNAS 2005; 102(32)11474-11479.

64. Uemura R, Xu M, Ahmad N, Ashraf M. Bone marrow stem cells prevent left ventricular remodeling of ischemic heart through paracrine signaling. Circ Res 2006; 98:1414-1421.

65. Virag JI and Murry CE. Myofibroblast and endothelial cell proliferation during murine myocardial infarct repair. Am J of Pathol. 2003; 163:2433-2440.

66. Jiang C, Gui C, He A, Hu X, Chen J, Jiang Y, Wang J. Optimal time for mesenchymal stem cells transplantation in rats with myocardial infarction. $\mathrm{J}$ Zhejiang Univ Sci. 2008;9(8):630-637.

67. Li RK, Mickle DA, Weisel RD, Rao V, Jia ZQ. Optimal time for cardiomyocytes transplantation to maximize myocardial function after left ventricular injury. $\mathbf{J}$ Ann Thorac Surg. 2001; 72(6):1957-63.

68. Hu X, Wang J, Chen J, Luo R, He A, Xie X, Li J. Optimal temporal delivery of bone marrow stem cells in rats with myocardial infarction. Eur J of Cardio-thorac Surg. 2007; 31:438-443.

69. Nakamura Y, Yasuda T, Weisel RD, Li R. Enhanced cell transplantation: preventing apoptosis increases cell survival and ventricular function. Am J Heart Circ Physiol. 2006; 291:939-947. 
70. Stolzing A and Scutt A. Effect of reduced culture temperature on antioxidant defences of mesenchymal stem cells. Free Radical Biol \& Med. 2006; 41:326338.

71. Young-shun L and Bing-ren G. Transplantation of neonatal cardiomyocytes plus fibrin sealant restores myocardial function in a rat model of myocardial infarction. Chin Med J. 2007; 120(22):2022-2027.

72. Fernandez P, Bordenave L, Celerier C, Bareille R, Brouillaud B. A novel potential application for ${ }^{99 \mathrm{~m}} \mathrm{Tc}-\mathrm{HMPAO}$ : endothelial cell labeling for in ivtro investigation of cell-biomaterial interactions. The J Nuclear Med. 1999; 40(10):1756-1763.

73. Iso Y, Spees JL, Serrano C, Bakondi B, Pochampally R, Song Y, Sobel BE, Delafontaine P, Prockop DJ. Multipotent human stromal cells improve cardiac function after myocardial infarction in mice without long-term engraftment. Biochem and Biophys Res Comm. 2007; 354:700-706.

74. Halkos ME, Zhao Z, Kerendi F, Wang N, Jiang R, Schmarkey LS, Martin BJ, Quyyumi AA, Few WL, Kin H, Guyton RA, Vinten-Johansen J. Intravenous infusion of mesenchymal stem cells enhances regional perfusion and improves ventricular function in a porcine model of myocardial infarction. Basic res Cardiol. 2008; 103(6):525-36.

75. Wolf D, Reinhard A, Katus HA, Kuecherer H, Hansen A. Dose-dependent effects of intravenous allogeneic mesenchymal stem cells in the infarcted porcine heart. Stem Cells Develop 2008 (in press).

76. Carr CA, Stuckey DJ, Tatton L, Tyler DJ, Hale SJM, Sweeney D, Schneider JE, Martin-Rendon E, Radda GK, Harding SE, Watt SM, Clarke K. Bone marrow- 
derived stromal cells home to and remain in the infarcted rat heart but fail to improve function: An in vivo cine-MRI study. Am J Physiol Heart Circ Physiol. 2008; 295(2):H533-42.

77. Kinnaird T, Stabile E, Burnett MS, Lee CW, Barr S, Fuchs S, Epstein SE. Marrow-derived stromal cells express genes encoding a broad spectrum of arteriogenic cytokines and promote in vitro and in vivo arteriogenesis through paracrine mechanisms. Circ Res. 2004; 94:678-685.

78. Silva WA, Covas DT, Panepucci RA, Proto-Siqueira R, Siufi JLC, Zanette DL, Santos ARD, Zago MA. The profile of gene expression of human marrow mesenchymal stem cells. Stem cells 2003; 21:661-669.

79. Guo J, Lin G, Bao C, Hu Z, Hu M. Anti-inflammation role for mesenchymal stem cells transplantation in myocardial infarction. Inflammation 2007; 30:97104.

80. Zhang S, Guo J, Zhang P, Liu Y, Jia Z, Ma K, Li W, Li L, Zhou C. Long-term effects of bone marrow mononuclear cell transplantation on left ventricular function and remodeling in rats. Life Sci. 2004; (74) 2853-2864.

81. Lian F, Xue S, Gu P, Zhu HS. The long-term effect of autologous endothelial progenitor cells from peripheral blood implantation on infarcted myocardial contractile force. The J Inter Med Res. 2008; 36:40-46. 
ANEXO I

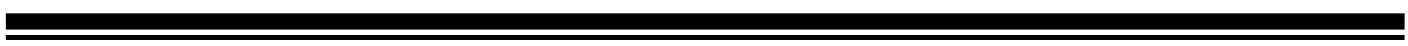


Uso de células-tronco do tecido adiposo previamente estimuladas com "shear stress" para o reparo do infarto do miocárdio em ratos 
O desenvolvimento de circulação colateral após o infarto do miocárdio é um mecanismo natural de adaptação do coração para aumentar a perfusão em regiões gravemente acometidas pela isquemia; pacientes infartados com circulação colateral evoluem com melhor prognóstico ${ }^{84 ; 85}$.

A angiogênese é o principal mecanismo envolvido na formação da nova rede vascular. Através da proliferação e migração de células endoteliais pré-existentes, são formados novos vasos que "brotam" de um vaso maduro em direção à região adjacente ao vaso. Entretanto a vasculogênese tem sido proposta como outro mecanismo de neoformação vascular envolvido em processos patológicos que envolvem resposta inflamatória tal como o que acontece como o infarto do miocárdio. Esse processo conta com a participação de células progenitoras endoteliais que, através da diferenciação, formarão novas estruturas vasculares.

A mobilização e homing de células progenitoras endoteliais têm sido demonstradas em contextos de isquemia ${ }^{86-88}$.

Uma série de fatores e citocinas, envolvidas no processo de recrutamento e diferenciação de progenitores endoteliais, são incrementados após a isquemia cardíaca. O fator de crescimento vascular (VEGF) e seus receptores (VEGFR2, VEGFR3, entre outros), estão entre os principais mediadores da vasculogênese pós-natal nesse contexto $31 ; 32 ; 89 ; 90$. 
O uso de terapias pró-angiogênicas para a recuperação do miocárdio infartado é fundamentado na baixa eficiência da vasculogênese e angiogênese pós-natal observada nesses casos.

A terapia gênica com VEGF está entre as principais abordagens para o reparo do infarto do miocárdio ${ }^{91 ; 92}$. Porém, é um procedimento alvo de sérias críticas que envolvem, essencialmente, a segurança dessa aplicação.

Terapia baseada no uso de células progenitoras e células-tronco também são realizadas e têm apresentado resultados positivos em modelos animais de infarto e humanos ${ }^{93-96}$.

Por outro lado, muitos dos tipos celulares empregados nessa abordagem são de baixa e difícil obtenção e manutenção ex vivo. Quando se trata de células-tronco embrionárias, os impedimentos envolvem questões éticas.

Células-tronco do tecido adiposo (CTTA) representam uma fonte promissora de células para os estudos de terapia celular. Essas células, além de exibirem plasticidade, proliferação e imunofenótipo compatível com células-tronco adultas como as isoladas da medula óssea, são de fácil obtenção e rendimento em cultura ${ }^{97-100}$. Além disso, secretam fatores importantes pró-angiogênicos e anti-apoptóticos ${ }^{101-103}$.

Estudos recentes têm sugerido que as células-tronco obtidas do tecido adiposo podem adotar fenótipo de células endoteliais e cardiomiócitos in vitro e in vivo ${ }^{104-106}$. 
Diversos métodos têm sido empregados para estimular a diferenciação de células-tronco de diferentes fontes em células endoteliais, dentre os quais o tratamento com VEGF é um dos mais testados ${ }^{107 ; 108}$. Aqui nós testamos um estímulo físico que mimetiza o "shear stress" (SS), isto é, a força gerada pelo fluxo laminar da coluna de sangue em células endoteliais.

Em células endoteliais, o SS desempenha um papel fundamental na regulação do fenótipo e função, envolvendo a produção de óxido nítrico (NO) e a expressão de VEGF, moléculas de adesão (VCAM, E-selectina, PECAM, vWF), entre outros ${ }^{109}$.

Adicionalmente, o "shear stress" tem sido reconhecido como importante modulador do fenótipo, morfologia, expressão gênica e diferenciação celular. Em linhagens de células embrionárias, células-tronco adultas e células musculares lisas o SS promoveu a diferenciação em células endoteliais ${ }^{110-114}$. A fosforilação de Akt (proteína quinase B) e a modulação da sinalização via receptores de VEGF estão entre os mecanismos envolvidos na mecanotransdução mediada pelo SS ${ }^{115 ; 116}$.

A associação de matrizes às células em protocolos de terapia celular tem sido testada em modelos animais de infarto. Uma das matrizes mais exploradas é o colágeno que, segundo os estudos, além de promover maior retenção das células injetadas, a matriz otimiza a angiogênese e estimula a sobrevida das células transplantadas ${ }^{117-120}$. 
Dado que o "shear stress" é um estímulo potencialmente indutor da diferenciação de células-tronco em células endoteliais, o presente estudo buscou avaliar o uso de células-tronco do tecido adiposo, previamente estimuladas com "shear stress", no reparo do coração de ratos infartados, através da aplicação direta dessas células em matriz de colágeno no coração. 
O objetivo principal desse trabalho foi investigar o papel de células-tronco obtidas do tecido adiposo (CTTA) e submetidas previamente ao "shear stress" no reparo estrutural e funcional do coração de ratos infartados.

Especificamente:

- Caracterizar a população de células-tronco obtidas do tecido adiposo (CTTA) branco de ratos;

- Perfil imunofenotípico

- Proliferação

- Potencial de diferenciação em múltiplas linhagens celulares

- Avaliar a morfologia das CTTA submetidas ao SS;

- Avaliar a expressão de moléculas específicas de células endoteliais em CTTA após estímulo com SS;

- Avaliar a produção de substâncias vasoativas (NO e VEGF) em CTTA após SS;

- Avaliar o efeito das CTTA-SS injetadas intramiocardicamente no coração de ratos infartados sobre parâmetros histopatológicos e hemodinâmicos da função cardíaca. 
Nota: serão mencionadas nessa sessão apenas as metodologias não descritas no item "materiais e métodos" dessa tese, pois grande parte dos ensaios do estudo a seguir foi desenvolvida com as mesmas técnicas.

Devido à indisponibilidade de reagentes, os experimentos in vitro com célulastronco de tecido adiposo (exceto os experimentos de expressão gênica em tempo real) foram realizados em células de camundongos da linhagem FVB.

\subsection{CULTURA DE CÉLULAS}

\subsubsection{Proliferação Celular}

Para avaliar as medidas de crescimento populacional, utilizamos protocolo descrito por Freshney ${ }^{82}$.

Células-tronco do tecido adiposo de camundongos da linhagem FVB (CTTA) nas passagens três e quatro foram plaqueadas na concentração de $1 \times 10^{4}$ células $/ \mathrm{cm}^{2} \mathrm{em}$ oito placas de $35 \mathrm{~mm}$ de raio. A cada dia, durante oito dias, células de uma das placas foram coletadas com $300 \mu \mathrm{L}$ de tripsina, $600 \mu \mathrm{L}$ de PBS e fixadas em $100 \mu \mathrm{L}$ de formaldeído $37 \%$. Posteriormente, as células foram contadas em hemocitômetro e calculadas numa concentração de $10^{4}$ células/mL.

O logaritmo $(\log )$ do número de células foi calculado e plotado num gráfico exponencial, a partir do qual obtivemos a curva de crescimento para as CTTA nas diferentes passagens. Nesse gráfico, identificou-se o momento do crescimento 
exponencial das células que gerou um gráfico de reta. A partir desse gráfico, calculou-se o tempo de dobramento das células.

A fórmula obtida a partir do coeficiente $(A)$ que determina a inclinação da reta (Y $=A \mathrm{x}+\mathrm{B})$ determina que este seja o divisor do número que representa a diferença entre o $\log$ de dois números quaisquer, de forma que um seja o dobro do outro.

\subsubsection{Diferenciação das Células-Tronco do Tecido Adiposo}

A plasticidade das células-tronco do tecido adiposo foi avaliada através da indução da diferenciação celular com a utilização de suplementação específica para cada linhagem de interesse no meio de cultura.

Brevemente, CTTA nas passagens três e quatro foram plaqueadas na concentração de $1 \times 10^{4}$ células $/ \mathrm{cm}^{2}$ e, após vinte e quatro horas, o meio de cultura convencional (DMEM low glucose $+10 \%$ FBS) foi substituído pelo meio de cultura específico para as linhagens adipogênica ou osteogênica, conforme descrito na tabela 4.

As CTTA foram mantidas por vinte e um dias com meio adipogênico ou osteogênico e o meio de cultura foi trocado a cada três dias. 


\begin{tabular}{ccc}
$\begin{array}{c}\text { Meios de } \\
\text { Diferenciação }\end{array}$ & Meio Base & Suplementação Específica \\
\hline Meio adipogênico & $\begin{array}{c}\text { DMEM low } \\
\text { glucose }+10 \% \\
\text { FBS }\end{array}$ & $\begin{array}{c}1 \mu \mathrm{M} \text { de Dexametasona, 0,5 mM de Isobutilmetilxantina, } \\
10 \mu \mathrm{M} \text { de Insulina e 200 } \mu \mathrm{M} \text { de Indometacina }\end{array}$ \\
Meio osteogênico & $\begin{array}{c}\text { DMEM low } \\
\text { glucose }+10 \%\end{array}$ & $\begin{array}{c}0,1 \mu \mathrm{M} \text { de Dexametasona, } 50 \mu \mathrm{g} / \mathrm{mL} \text { de Ácido ascórbico, } \\
10 \mu \mathrm{M} \text { de Beta-glicerofosfato }\end{array}$ \\
\hline
\end{tabular}

Tabela 4. Descrição dos meios de cultura utilizados para diferenciação adipogênica e osteogênica das células-tronco do tecido adiposo.

Ao final do período de tratamento, os respectivos meios de culturas foram retirados, as CTTA foram lavadas com PBS $1 \mathrm{X}$ e procederam-se os protocolos pertinentes para a visualização dos respectivos tipos celulares, adipócitos e osteócitos.

\subsubsection{Coloração “Oil Red” para Adipócitos}

A diferenciação em adipócitos foi avaliada através da coloração de "Oil Red” nas células submetidas ao meio adipogênico e naquelas mantidas em meio padrão. Para esse teste, foi realizado protocolo descrito a seguir.

Após a fixação das células por uma hora em formaldeído $10 \%$ essas foram lavadas duas vezes com água destilada e em seguida uma vez com álcool a $70 \%$. Posteriormente, todo álcool foi removido para a adição do corante Escarlat R ou Sudan IV por cinco minutos. Após esse tempo, as células foram lavadas por duas vezes com álcool a $70 \%$ e mantidas em água destilada até o final da análise microscópica e a obtenção das imagens fotográficas. 


\subsubsection{Ensaio de Von Kossa para Osteócitos}

Para a diferenciação em osteócitos, CTTA mantidas em meio osteogênico e àquelas mantidas em meio padrão como controles, foram submetidas à reação de Von Kossa. Para essa reação, as células foram fixadas com paraformaldeío $4 \%$ por uma hora à temperatura ambiente. Após esse período as células foram lavadas com água destilada e mantidas submersas em solução $1 \%$ de nitrato de prata na ausência de luz por trinta minutos. Em seguida as células foram lavadas por várias vezes com água destilada e submetidas à luz UV por uma hora. Através desse protocolo é possível observar a oxidação da prata impregnada no cálcio da matriz extracelular.

\subsubsection{Estimulação das Células-Tronco do Tecido Adiposo com "Shear Stress"}

Para a produção de "shear stress" foi utilizado o sistema de "cone plate" (figura 21), que é o método tradicional de produzir "shear stress" in vitro (Malek A e cols., 1992). Este sistema consiste de um cone, de ângulo superficial de $0,5^{\circ}$, girando sobre o meio de cultura das células. A velocidade angular $(\omega)$ do cone é controlada e o "shear stress" é calculado através da fórmula abaixo:

$$
\tau=\eta \omega . \alpha^{-1}
$$

onde: $\tau$ é o "shear stress" (dinas $/ \mathrm{cm}^{2}$ ), $\eta$ a viscosidade do meio de cultura (dinas.s $/ \mathrm{cm}^{2}$ ), $\omega$ a velocidade angular do cone ( $\left.\mathrm{rad}_{\mathrm{s}}{ }^{-1}\right)$ e $\alpha$ o ângulo superficial do cone (rad.). 

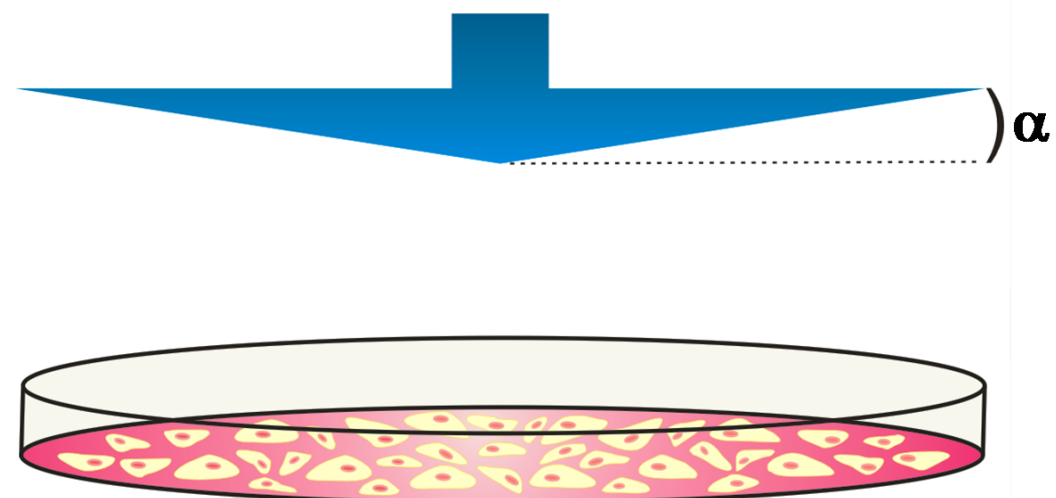

$$
\tau=\frac{\eta \omega}{\alpha}
$$

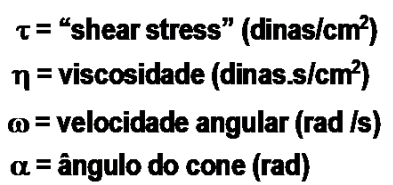

Figura 21: Sistema de "cone plate" utilizado para produção de "shear stress" nas células-tronco de tecido adiposo. O cone gira sobre as CTTA e o SS pode variar através de alterações na velocidade angular ou da viscosidade do meio de cultura.

As células-tronco do tecido adiposo de camundongos e ratos foram submetidas ao "shear stress" de 10 dinas $/ \mathrm{cm}^{2}$ por um período de 72 horas no sistema de "cone plate”. Em seguida as CTTA foram tripsinizadas e contadas para a análise de expressão por citometria de fluxo, lisadas em Trizol para a extração de RNA e, em outra ocasião, para os estudos in vivo.

\subsubsection{Determinação de Óxido Nítrico}

O acúmulo de nitrito no meio de cultura foi aferido como uma medida indireta da produção de óxido nítrico (NO) pelas células, utilizando-se o ensaio colorimétrico de Griess ${ }^{83}$. Nesse experimento, $100 \mu \mathrm{L}$ do meio de cultura foram misturados com $100 \mu \mathrm{L}$ 
do reagente de Griess ( $50 \mu \mathrm{L}$ de $1 \%$ de sulphanilamida em água e $50 \mu \mathrm{L}$ de $0,1 \%$ de naphitilethelen-diamine-dihydrochloride em 2,5 $\mathrm{M}$ de $\mathrm{H}_{3} \mathrm{PO}_{4}$ ). Após dez minutos de incubação para estabilizar a reação, realizou-se a leitura de absorbância em 540 nm. As leituras dos meios de cultura de CTTA não submetidas ao "shear stress" foram utilizadas como controle. A concentração de nitrito no meio de cultura foi determinada por meio da curva-padrão preparada a partir de concentrações conhecidas de nitrito de sódio.

\subsubsection{Detecção de VEGF}

Para dosagem de VEGF de origem murina no meio de cultura das CTTA foi utilizado o método ELISA (do inglês, enzyme-linked immunoabsorbent assay) (R\&D System, Inc., Minneapolis, USA). Este ensaio foi realizado em amostras de meio de cultura.

Uma Placa com 96 poços foi sensibilizadas com $100 \mu \mathrm{L}$ de anticorpo monoclonal anti-mouse VEGF e incubada por 18 horas a $4{ }^{\circ} \mathrm{C}$. Posteriormente, a placa foi bloqueada para evitar ligações inespecíficas com $300 \mu \mathrm{L}$ de solução de bloqueio (BSA 2\%) e incubada por 2 horas à $37^{\circ} \mathrm{C}$. Após o bloqueio, foram adicionados $100 \mu \mathrm{L}$ por poço das amostras e dos padrões diluídos previamente em PBS 1X. Em dois poços foram colocados somente PBS 1X para caracterização do branco. A placa foi incubada por dezoito horas a $4{ }^{\circ} \mathrm{C}$. Após incubação, foram adicionados $100 \mu \mathrm{L}$ do anticorpo conjugado (anticorpo anti-human Biotinilado) na concentração estabelecida e o material incubado por 3 horas a $37{ }^{\circ} \mathrm{C}$. Posteriormente, foram adicionados $100 \mu \mathrm{L}$ de Streptoavidina HRP (1:250) por poço e incubado por 30 minutos a $37^{\circ} \mathrm{C}$. A cada etapa a 
placa foi lavada com tampão de lavagem (PBS + Tween 20\%) por seis vezes. A revelação foi realizada através da adição de $100 \mu \mathrm{L}$ /poço de solução de $\mathrm{H}_{2} \mathrm{O}_{2}$ e tetrametilbenzidina, incubando-se de cinco a sessenta minutos a $37{ }^{\circ} \mathrm{C}$. A reação foi interrompida com $50 \mu \mathrm{L}$ de $\mathrm{H}_{2} \mathrm{SO}_{4} 30 \%$ por poço sob agitação lenta. A leitura foi feita em leitor de ELISA (Power Wave, Bio-tek) utilizando filtro de $450 \mathrm{~nm}$.

\subsubsection{Ensaio da Formação de Estruturas Tubulares Através de Matrigel}

A capacidade de formar estruturas similares à capilares foi examinada nas CTTA submetidas ao regime de "shear stress". Para tal, CTTA submetidas ou não ao SS foram plaqueadas na concentração de $0,5 \times 104$ células $/ \mathrm{cm}^{2}$ em placas de 96 poços contendo 20 $\mu \mathrm{L}$ de matriz de colágeno (matrigel - BD Bioscience ${ }^{\circledR}$ ). Células endoteliais de artéria de coelhos (rabbit endothelial cell - REC) foram plaqueadas na mesma concentração e utilizadas como controle positivo do ensaio. Após vinte e quatro horas as células foram observadas em microscópio óptico invertido de contraste de fase (Nikon Eclipse®) e fotografadas.

\subsection{EXPRESSÃO GÊNICA}

\subsubsection{Extração de RNA}

Para isolar o RNA (ácido ribonucléico) das CTTA, procedeu-se o protocolo descrito pelo fabricante do reagente Trizol®, solução anti-RNAse utilizada para coleta e armazenamento dessas células. O Trizol@Reagent, uma solução monofásica de fenol e 
guanidina isotilcianato, corresponde a uma variação do método desenvolvido por Chomczynski e Sacchi (1987).

Todo o procedimento foi realizado com os devidos cuidados para evitar a contaminação com RNAse (enzima anti- RNA), através do uso de luvas e de solução "RNAse-free". A partir desta etapa, segue-se o protocolo de extração de RNA, conforme instruções do fabricante. CTTA homogeneizadas com trizol foram centrifugadas por dez minutos a $1200 \mathrm{rpm} \mathrm{em} 4{ }^{\circ} \mathrm{C}$. O sobrenadante foi transferido para outro eppendorf e a ele foram adicionados $200 \mu \mathrm{L}$ de clorofórmio sob agitação. A mistura foi incubada por 3 minutos à temperatura ambiente. Após esse tempo, a amostra do eppendorf foi novamente centrifugada por quinze minutos a $1200 \mathrm{rpm}$ a $4{ }^{\circ} \mathrm{C}$. Novamente o sobrenadante foi transferido para outro eppendorf e a ele foram adicionados $500 \mu \mathrm{L}$ de isopropanol. A mistura foi incubada por dez minutos à temperatura ambiente. Após essa incubação, a amostra foi centrifugada por dez minutos a $1200 \mathrm{rpm}$ em $4^{\circ} \mathrm{C}$. O sobrenadante foi descartado e ao pellet foi adicionado $1 \mathrm{~mL}$ de etanol a $75 \%$. Após agitação nessa solução, a amostra foi centrifugada por cinco minutos a $7500 \mathrm{rpm}$ a $4{ }^{\circ} \mathrm{C}$. O sobrenadante foi retirado e o pellet foi seco naturalmente à temperatura ambiente. $\mathrm{Na}$ última etapa, o pellet seco foi ressuspendido em água milliQ.

A integridade das amostras foi verificada através de eletroforese em gel de agarose $1 \%$ (1\% agarose, $40 \mathrm{mM}$ Tris acetato e $2 \mathrm{mM}$ EDTA - TAE), contendo 0,5 $\mu \mathrm{g} / \mathrm{mL}$ de brometo de etídeo. O gel foi imerso em tampão TAE $1 \mathrm{X}$ e a eletroforese realizada a $100 \mathrm{~V}$ por aproximadamente quarenta e cinco minutos. 


\subsubsection{Transcrição Reversa}

Para a síntese do cDNA (ácido desoxirribonucléico codificante) a partir de RNA obtido em etapa anterior, foram utilizados $5 \mu \mathrm{g}$ de RNA total extraído das CTTA. As amostras foram incubadas com $0,5 \mu \mathrm{g} / \mathrm{mL}$ de oligo dT12-18 a $65{ }^{\circ} \mathrm{C}$ por cinco minutos, para se obter a primeira fita de cDNA.

A transcrição reversa das amostras foi realizada em um volume total de $20 \mu \mathrm{L}$ contendo $10 \mathrm{mM}$ de dNTPs (desoxirribonucleotídeos trifosforilados), 0,1 M de DTT, 1X tampão da enzima, 3U de RNAsin e 2,5U de transcriptase reversa (AMV-RT). Após incubação por 1 hora a $37^{\circ} \mathrm{C}$, a temperatura foi elevada a $95^{\circ} \mathrm{C}$ por cinco minutos e as amostras rapidamente colocadas em gelo para denaturação de híbridos RNA-cDNA formados e inativação da enzima utilizada na reação. Em alguns tubos, a transcriptase reversa não foi adicionada, a fim de se controlar a contaminação ou amplificação de DNA genômico. O cDNA obtido foi estocado a $-20{ }^{\circ} \mathrm{C}$ até o momento da realização da reação de PCR (reação de polimerização em cadeia) em tempo real.

\subsubsection{PCR em Tempo Real}

Após a síntese de cDNA a partir de RNA total, o PCR em tempo real foi realizado utilizando o kit SYBR® Green PCR Master Mix de acordo com instruções do fabricante. A reação de PCR em tempo real foi realizada no ABI PRISM 7700 Sequence Detector, através de oligonucleotídeos iniciadores específicos (tabela 5) para o gene de interesse e detecção por SYBR Green. 
Nesta metodologia, o PCR foi combinado a um intercalante fluorescente de DNA dupla fita, o SYBR Green I. Desta forma, um sinal fluorescente gerado é diretamente proporcional à quantidade de produto de PCR na reação. A intensidade de fluorescência é monitorada após cada ciclo do PCR, o que possibilita a análise durante a fase exponencial da reação. Para obter resultados reprodutíveis e com exatidão, a eficiência da reação deve ser próxima de $100 \%$, ou seja, a quantidade de DNA deve duplicar após cada ciclo da fase exponencial.

\begin{tabular}{|c|c|c|c|}
\hline Genes & Primer Senso $\left(5^{\prime} \rightarrow 3^{\prime}\right)$ & Primer Anti-senso $\left(3^{\prime} \rightarrow 5^{\prime}\right)$ & Amplicon (pb) \\
\hline $\mathrm{vWf}$ & agaggatgcggtggctaac & cctgcgatgaatctatgagga & 90 \\
\hline FLk-1 & cagtgatcgccatgttcttc & cttcagttccccttcattgg & 80 \\
\hline Notch & gagatgctcccagccaagt & cggtactcacacacaggcttc & 82 \\
\hline Jagged & gattactgcgagcccaacc & ggtctttcaggtgtgagcag & 80 \\
\hline GAPDH & gaacttgccgtgggtagag & atggtgaaggtcggtgtg & 162 \\
\hline
\end{tabular}

Tabela 5. Sequiência dos oligonucleotídeos iniciadores utilizados para avaliar a expressão de proteínas específicas em CTTA submetidas ao "shear stress". Na tabela estão descritas as seqüências dos "primers" utilizados para a análise da expressão dos genes que codificam para as proteínas específicas de células endotelais (vWf e FLK-1) e dois marcadores relacionados à diferenciação celular (Notch e Jagged). Na coluna à direita estão indicados os tamanhos dos "amplicons" (produtos da reação de PCR) em pares de bases $(\mathrm{pb})$ produzidos pelos "primers". GAPDH foi utilizado como normalizador da expressão gênica.

\subsection{EXPRESSÃO DE PROTEÍNAS}

\subsubsection{Análise Quantitativa da Expressão Proteica por Citometria de Fluxo}

Citometria de Fluxo (Fluorescence Activated Cell Sorting - FACS) foi empregada para avaliar o imunofenótipo das células-tronco de tecido adiposo. O FACS foi também utilizado como ferramenta para detectar e quantificar a expressão de proteínas endotélioespecíficas em CTTA submetidas ao regime de "shear stress" (SS). 
Para a caracterização imunofenotípica, as células-tronco do tecido adiposo na terceira e quarta passagens foram tripsinizadas e contadas, conforme já descrito, e ressuspendidas em meio de cultura até o momento da realização do protocolo de marcação. Posteriormente foram submetidas ao protocolo de marcação com os anticorpos listados na tabela 2. Foram necessárias 200.000 células por anticorpo testado. Os ensaios foram realizados com marcações simples e triplas, conforme a tabela 6. Foram utilizados oito anticorpos para as diferentes proteínas (BD - Pharmingen) e cinco controles isotípicos para cada um dos fluorocromos (BD - Pharmingen). A condição de células sem marcação também foi utilizada para a padronização das fluorescências.

O ensaio foi desenvolvido da seguinte maneira: as células foram adicionadas na placa de 96 poços e centrifugadas a $1800 \mathrm{rpm}$ por cinco minutos para eliminar o meio de cultura. Posteriormente foram adicionados $200 \mu \mathrm{L}$ em cada poço de tampão de lavagem de citometria e a placa foi novamente centrifugada. Este procedimento foi realizado por duas vezes. Em seguida, foram adicionados $10 \mu \mathrm{L}$ de cada anticorpo nos devidos poços da placa. Os anticorpos foram incubados por trinta minutos na ausência de luminosidade, quando então foram adicionados $150 \mu \mathrm{L}$ de tampão de lavagem e foi realizada a centrifugação das amostras retirando-se o sobrenadante por inversão da placa. Repetiu-se a lavagem e as amostras foram passadas para tubos de citometria e adquiridas no citômetro BD FACSCalibur, através do software CellQuest Pro. Foram adquiridos 10.000 eventos na região selecionada por tamanho e granulosidade. 


\begin{tabular}{|c|c|}
\hline Proteína & Anticorpo \\
\hline CD29/ CD31/ CD90 & IgG FITC/IgG2a PE/ IgG1 PerCP \\
\hline CD105/ CD73/ CD45 & IgG2a FITC/ IgG2a PE/ IgG2 $2_{b}$ PeCy5 \\
\hline Sca-1/ CD44/ CD45 & $\mathrm{IgG} 2 \mathrm{a} \mathrm{PE} / \mathrm{IgG} 2_{\mathrm{b}}$ APC/ IgG2 $2_{\mathrm{b}}$ PeCy5 \\
\hline Flk-1/ CD31 & IgG2a FITC/ IgG2a PE \\
\hline Isotipo controle & IgM FITC \\
\hline Isotipo controle & $\operatorname{IgG} 2 \mathrm{a} P E$ \\
\hline Isotipo controle & IgG1 PerCP \\
\hline Isotipo controle & $\operatorname{IgG} 2_{b} \mathrm{APC}$ \\
\hline Isotipo controle & $\operatorname{IgG} 2_{\mathrm{b}} \mathrm{PeCy} 5$ \\
\hline
\end{tabular}

Tabela 6. Anticorpos analisados nas células-tronco do tecido adiposo. Na coluna à esquerda estão representadas as proteínas estudadas e as combinações avaliadas nas CTTA e à direita os anticorpos para essas proteínas conjugados com os referidos fluorocromos. FITC, PE, PerCP, PeCy5 e APC, indicam, respectivamente, os fluoróforos conjugados aos anticorpos nas cores verde, laranja, vermelho, vermelho escuro.

Para a avaliação das CTTA submetidas ao "shear stress", foi empregado o mesmo procedimento de marcação, porém foram incubados apenas os anticorpos anti CD31 e Flk-1.

\subsection{ESTUDO IN VIVO COM CÉLULAS-TRONCO DE TECIDO ADIPOSO}

\subsubsection{Desenho Experimental}

Os procedimentos cirúrgicos experimentais realizados nesse estudo já foram descritos na sessão "materiais e métodos" dessa tese. Porém os infartos nesse estudo foram realizados em fêmeas da linhagem Lewis e machos da mesma linhagem foram 
utilizados como doadores das CTTA. A escolha por fêmeas se deu em razão dos estudos a posteriori que serão desenvolvidos com o objetivo de localizar as células injetadas através de sondas específicas para genes do cromossomo Y.

Cabe ressaltar que os animais foram infartados através do procedimento de ligadura permanente da artéria coronária e, submetidas ou não ao implante de CTTA, vinte e quatro horas após o infarto. Na tabela seguinte estão relacionados os grupos experimentais estudados. As avaliações histológicas e da função cardíaca foram realizadas trinta dias após o infarto do miocárdio.

\begin{tabular}{|c|c|c|}
\hline Grupos & IAM & Tratamento \\
\hline Sham & - & - \\
\hline NT & + & - \\
\hline COL & + & Colágeno \\
\hline CTTA & + & CTTA+ colágeno $\left(1 \times 10^{6}\right)$ \\
\hline CTTA+SS & + & CTTA+SS+ colágeno $\left(1 \times 10^{6}\right)$ \\
\hline
\end{tabular}

Tabela 7. Detalhes dos grupos experimentais do estudo in vivo com CTTA. Na coluna da esquerda estão listados os nomes dados aos grupos experimentais; na coluna central os sinais + e - indicam, respectivamente, a presença ou ausência do infarto agudo do miocárdio (IAM) e na coluna à direita estão listados os detalhes do tratamento, onde - indica ausência de qualquer procedimento após o infarto e colágeno, CTTA e CTTA+SS indicam o conteúdo das injeções intramiocárdicas realizadas após o IAM.

\subsubsection{Extração de Colágeno a partir da Cauda de Ratos}

Caudas de 10 ratos machos Lewis foram cortadas na sua base, lavadas com detergente e colocadas em recipiente com álcool $70 \%$ a $4{ }^{\circ} \mathrm{C}$, por 24 horas. Para extrair as fibras de colágeno tipo $\mathrm{I}$, as pontas das caudas foram torcidas até quebrar a articulação da vértebra mais distal. Com o auxílio de uma pinça dentada, as vértebras 
desarticuladas foram puxadas com movimentos giratórios de maneira de retirar o colágeno. As fibras de colágeno foram então cortadas e colocadas num recipiente contendo uma solução estéril de ácido acético a $1 \%$. Esse procedimento foi repetido para cada vértebra. As fibras permaneceram na solução estéril de ácido acético a $1 \%$ até serem dissolvidas. A seguir, a solução foi ultracentrifugada a 30000 g por duas horas e o sobrenadante foi estocado a $4{ }^{\circ} \mathrm{C}$.

Para a preparação das alíquotas de colágeno utilizadas como veículo para o implante das CTTA, foi adicionada à solução de colágeno $1,5 \mu \mathrm{L} / \mathrm{mL}$ de Phenol Red a 1 $\%$ para controle do $\mathrm{pH}$ e posteriormente uma quantidade suficiente de $\mathrm{NaOH} 1 \mathrm{M}$ até alcançar o pH neutro. $100 \mu \mathrm{L}$ dessa solução foi aliquotado para a mistura com as CTTA injetadas. Durante todas as etapas de preparo, o colágeno foi mantido em gelo para evitar sua polimerização espontânea.

\subsection{AVALIAÇÃO HISTOLÓGICA}

\subsubsection{Imunofluorescência}

As CTTA injetadas nos corações dos ratos infartados foram identificadas e avaliadas através de reação de imunofluorescência. As lâminas foram obtidas segundo o procedimento já descrito para a avaliação histológica.

Brevemente, para a reação de imunofluorescência, cortes de $6 \mu \mathrm{m}$ dos corações foram utilizados. As lâminas contendo os cortes foram desparafinizadas a $65{ }^{\circ} \mathrm{C}$ e posteriormente banhadas em xilol por três vezes durante vinte minutos cada vez. Em 
seguida foram lavadas numa solução contendo PBS 0,1 \% Tween. Três incubações em peróxido de hidrogênio de sete minutos cada uma foram realizadas posteriormente. A seguir as lâminas foram lavadas em água corrente.

O bloqueio de ligações inespecíficas foi realizado através da incubação das lâminas em solução de PBS a $2 \%$ de caseína (Sigma-Aldrich®). As lâminas foram mantidas nessa solução por sessenta minutos à temperatura ambiente. Após esse tempo, as lâminas foram retiradas da solução e escorridas para a incubação com o anticorpo primário anti - Flk-1 1:50 (Upstate®) ou anti - vWf 1:100 (Abcam®) . As lâminas foram incubadas por $1 \mathrm{~h}$ em temperatura ambiente. Após esse tempo, as lâminas foram lavadas com PBS e em seguida procede-se a incubação com os respectivos anticorpos secundários, anti-mouse Alexa fluor 488 1:600 e anti-rabbit Alexa fluor 488 1:600 (Molecular Probes ${ }^{\circledR}$ ), por uma hora e trinta minutos em temperatura ambiente protegida da luz. As reações para cada uma das proteínas estudadas foram realizadas em lâminas separadas.

Finalmente, as lâminas foram lavadas por três vezes em PBS para a retirada dos anticorpos residuais que eventualmente não se ligaram e então as lâminas foram montadas em meio de montagem com DAPI (Molecular Probes®) em solução de glicerol $50 \%$. 


\subsection{CARACTERIZAÇÃO DAS CÉLULAS-TRONCO DO TECIDO ADIPOSO}

\subsubsection{Proliferação Celular}

Células-tronco derivadas do tecido adiposo (CTTA) foram cultivadas e utilizadas para os experimentos nas passagens 3 e 4 . Nesse intervalo foram avaliadas as curvas de crescimento das células (figura 22), a partir das quais se obteve o tempo de dobramento médio da população $(68,07 \pm 2,12 \mathrm{~h})$.

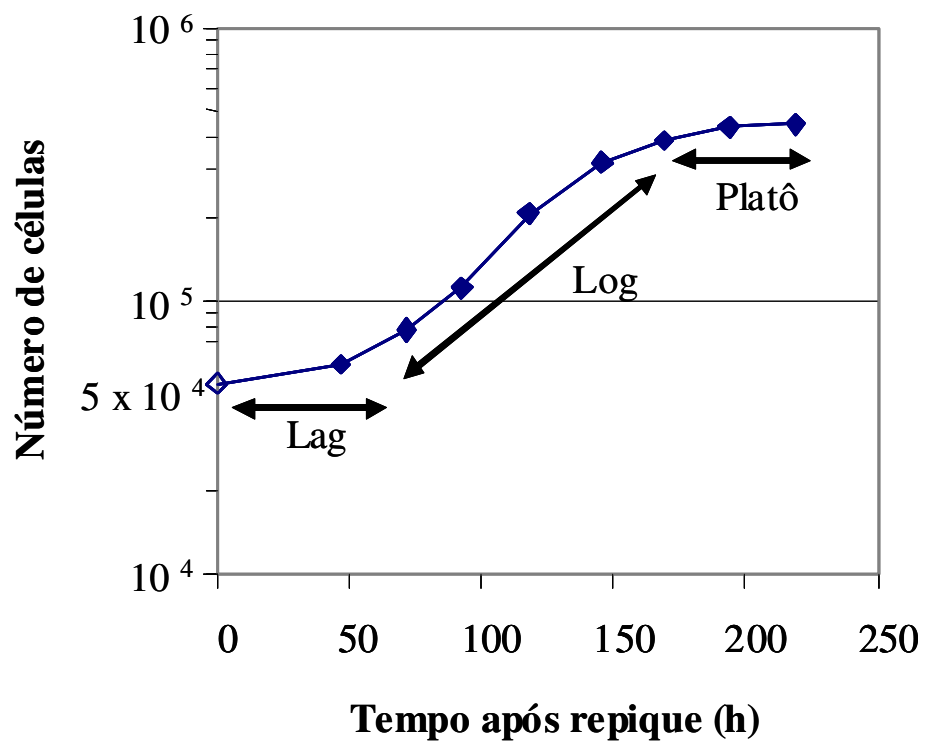

Figura 22. Curva de crescimento das células-tronco de tecido adiposo na passagem 3. O gráfico mostra o número de células em função do tempo em cultura. 


\subsubsection{Perfil Imunofenotípico}

O perfil dos marcadores CDs nas CTTA foi avaliado com base no painel proposto para as células mesenquimais da medula conforme a similaridade já descrita entre ambos os tipos celulares.

CTTA na passagem 3 foram avaliadas quanto à expressão das proteínas de superfície amplamente expressas por células mesenquimais - CD29 (integrina $\beta 1$ ), CD90 (Thy-1; thymocyte differentiation antigen 1), CD105 (endoglina), CD44 (glicoproteína de adesão celular e migração), CD73 (Ecto-5'-nucleotidase), Sca-1 (stem cell antigen 1), e por outro lado, quanto à expressão de proteínas das linhagens endotelial e hematopoiética - CD31 (Platelet Endothelial Cell Adhesion Molecule-1) e CD45 (antígeno expresso em leucócitos). Assim, a expressão incrementada dos marcadores mesenquimais e a baixa ou ausente expressão dos marcadores endoteliais/hematopoiéticos é o painel que define as células-tronco derivadas do tecido adiposo (CTTA).

A figura 23 mostra os níveis de expressão desses marcadores de superfície na população de CTTA, avaliados através de citometria de fluxo. 


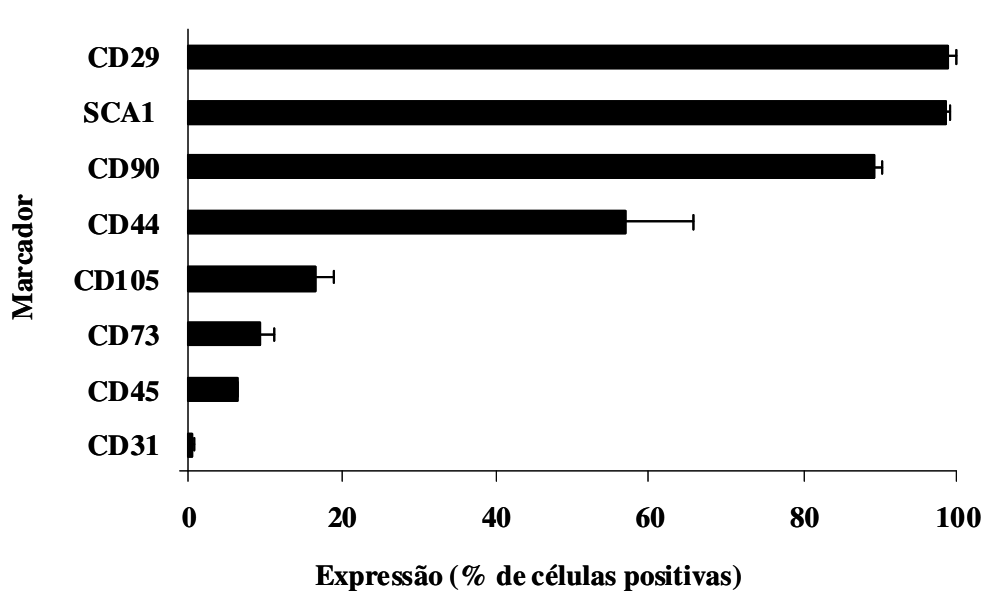

\begin{tabular}{|c|c|}
\hline Marcador & $\begin{array}{c}\text { \% Células positivas } \\
\text { (média } \pm \text { EPM) }\end{array}$ \\
\hline CD29 & $98,97 \pm 0,85$ \\
\hline SCA1 & $98,75 \pm 0,49$ \\
\hline CD90 & $89,19 \pm 1,76$ \\
\hline CD44 & $57,09 \pm 16,89$ \\
\hline CD105 & $16,52 \pm 6,80$ \\
\hline CD73 & $9,02 \pm 1,73$ \\
\hline CD45 & $6,41 \pm 0,09$ \\
\hline CD31 & $0,55 \pm 0,31$ \\
\hline
\end{tabular}

Expressão (\% de células positivas)

Figura 23. Análise da expressão de marcadores CDs em CTTA através de citometria e fluxo. Os valores estão expressos como percentagem média de células positivas para os marcadores \pm erro-padrão da média; $\mathrm{n}=4$ experimentos.

Conforme ilustrado no painel acima, a maioria das células da população avaliada expressava os marcadores CD 29, Sca-1 e CD90 (cerca de 90\% da população). Outros marcadores sabidamente presentes em células-tronco mesenquimais foram observados na mesma população, como o CD44 e CD105, porém num grupo menos de células. Por outro lado, os marcadores hematopoiéticos e endoteliais estiveram presentes numa freqüência muito baixa, mostrando que a cultura estava composta predominantemente por células-tronco de origem mesenquimal. 


\subsubsection{Plasticidade das Células-tronco do Tecido Adiposo}

Com o objetivo de avaliar a capacidade das células-tronco do tecido adiposo de adquirir fenótipo de linhagens celulares distintas, cultivamos CTTA em meios de cultura específicos e descritos para indução da adipogênese e osteogênese.

Adipogênese. Nesse protocolo avaliamos a capacidade das CTTA adquirirem o fenótipo de adipócitos quando estimuladas especificamente. As células foram submetidas ao cultivo com meio de diferenciação adipogênico durante 21 dias. A partir do quinto dia de tratamento, alterações morfológicas começaram a ser observadas nas CTTA. Essas modificações foram evidentes no citoplasma celular, cujo tamanho tornou-se maior que o das células mantidas sob as condições habituais de cultivo (dados não mostrados). Após 15 dias, a formação de vesículas citoplasmáticas relacionadas à deposição lipídica, pôde ser observada. Ao final do período experimental, as CTTA submetidas ou não ao meio de cultura específico foram coradas com Oil Red para confirmação da deposição lipídica intracelular. Vesículas lipídicas marcadas em vermelho foram observadas nas CTTA tratadas com meio específico para indução da adipogênese, mostrando que essas células são capazes de se diferenciar em adipócitos maduros quando estimuladas quimicamente. Figura 24.

Osteogênese. O objetivo desse experimento foi avaliar a capacidade das CTTA adquirirem o fenótipo de osteócitos. Mudanças na morfologia das células foram também observadas aqui. As CTTA cultivadas no meio específico para indução da osteogênese apresentaram mudanças na morfologia do citoplasma após cerca de 10 dias do início do 
tratamento. O citoplasma dessas células tornou-se gradativamente retraído e granuloso. Outra mudança importante globalmente observada na placa foi a condensação da população de células, de forma a aparecerem em "ninhos" mais ou menos isolados. A mineralização da matriz foi confirmada através do acúmulo extracelular de cálcio evidenciado pela coloração de Von Kossa. Figura 24.
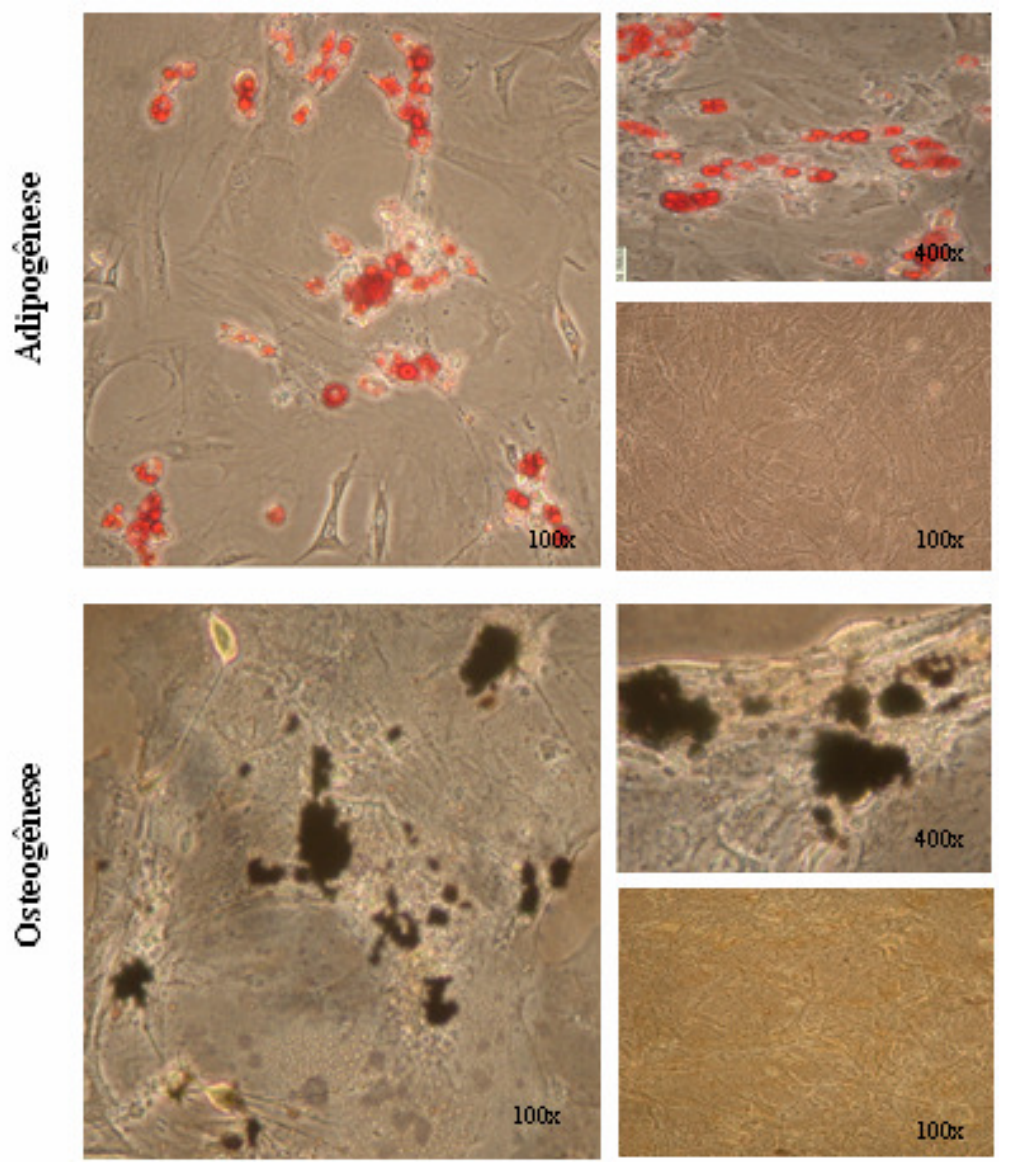

Figura 24. Adipogênese e osteogênese a partir de CTTA observada através de microscopia óptica de contraste de fase. No painel superior, a formação de adipócitos é mostrada através da coloração em vermelho das vesículas lipídicas intracitoplasmáticas. No painel inferior as "manchas" em preto são produto da oxidação da prata impregnada nos locais onde há deposição de cálcio, evidenciando a mineralização da matriz extracelular na cultura de CTTA. 


\subsection{EFEITO DO "SHEAR STRESS" EM CÉLULAS-TRONCO DO TECIDO ADIPOSO - MORFOLOGIA, EXPRESSÃO GÊNICA E PROTEICA}

\subsection{1 "Shear Stress" Promove Mudança na Morfologia das Células-Tronco do Tecido Adiposo}

CTTA submetidas ao "shear stress" (SS) de 10 dynas $/ \mathrm{cm}^{2}$ durante 72 horas, exibiram mudança na morfologia quando comparadas às células mantidas em condição estática. $\mathrm{O}$ aspecto geral da população de células evidenciou a orientação e alinhamento das mesmas paralelamente ao sentido do fluxo gerado no sistema de "cone plate". Figura 25.

Estática

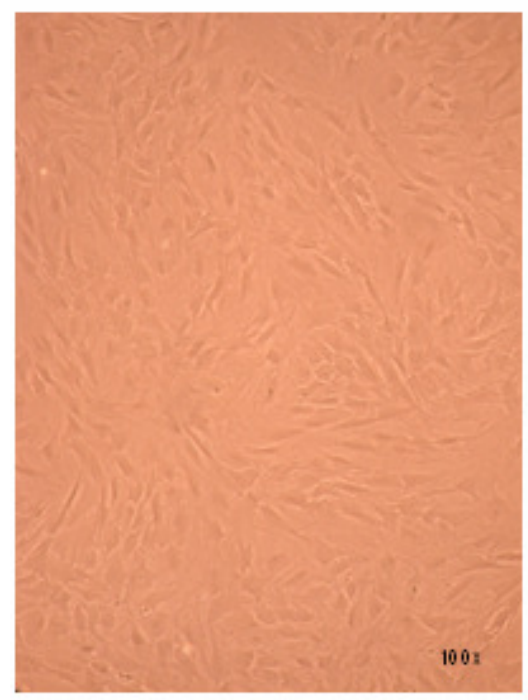

1008
Shear Stress

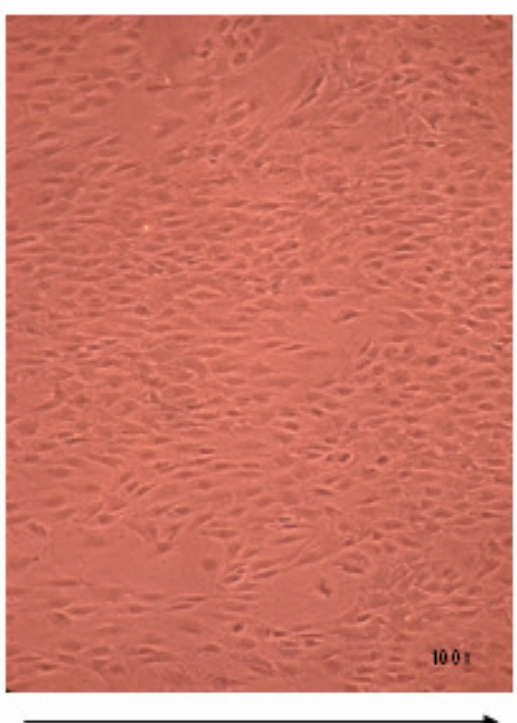

Fluxo

Figura 25. Efeito do "shear stress" (SS) sobre a morfologia e alinhamento das CTTA. Microscopia óptica de contraste de fase de CTTA em condição estática (esquerda) e sob regime de SS $\left(10\right.$ dynas $\left./ \mathrm{cm}^{2}\right)$ após 72 horas de experimento. 
Nas CTTA expostas ao fluxo laminar a proliferação foi incrementada (estáticas: $1,76 \pm 0,33$ células $/ \mathrm{cm}^{2}$ vs. $\mathrm{SS}: 2,68 \pm 0,35$ células $\left./ \mathrm{cm}^{2}\right)$. Além disso, as células deixaram de apresentar o aspecto "fibroblastóide" característico.

\subsection{2 “Shear Stress” Induz a Expressão de CD31, Flk-1 E vWf em Células-Tronco do Tecido Adiposo}

\section{Expressão Gênica}

Com o objetivo de testar a hipótese de que o "shear stress" é potencialmente indutor da diferenciação em células endoteliais, foi avaliada a expressão de genes relacionados ao fenótipo e função de células endoteliais nas CTTA submetidas ao SS e naquelas mantidas em condição estática do meio de cultura. PCR em tempo real foi realizado para avaliar a expressão dos seguintes genes: FLK-1 ou VEGFR2 (receptor 2 tirosina-quinase da proteína VEGF), vWf (fator de von Willebrand, glicoproteína relacionada à adesão plaquetária), Notch (receptor de sinalização célula-célula, envolvido na diferenciação e sobrevida celular) e Jagged (ligante do receptor Notch). A expressão foi normalizada por GAPDH e a comparação da expressão foi feita em relação às células em condição estática. Figura 26. 
FKL-1
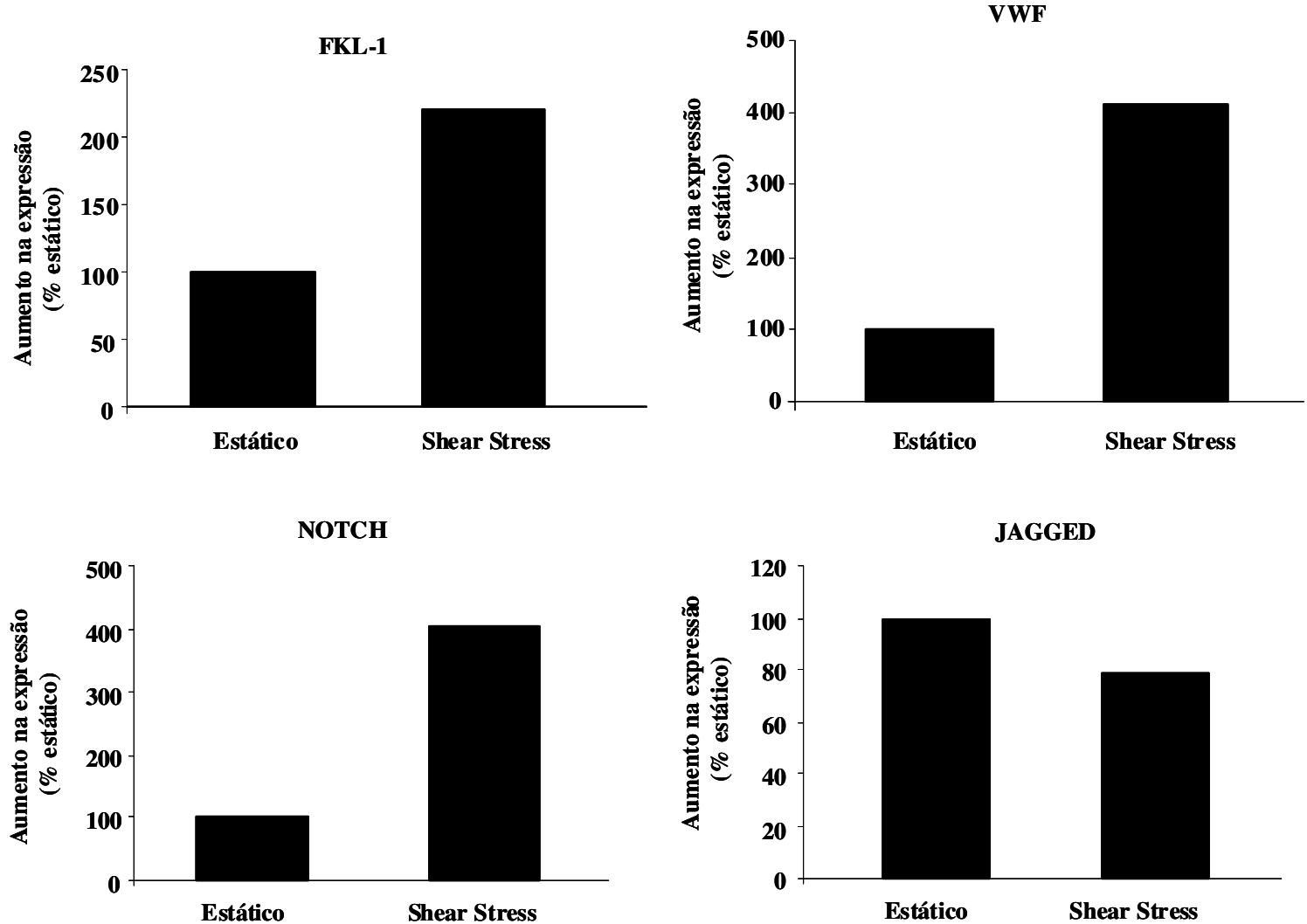

Figura 26. PCR em tempo real de CTTA submetidas ao "shear stress" para os genes FLK-1, vWf, Notch e Jagged conforme indicado. A expressão gênica foi normalizada pela expressão de GAPDH. As barras representam o incremento na expressão comparada à expressão nas CTTA mantidas em condição estática. Os valores são representativos da média do delta CT (coeficiente de variação da expressão) de 5 experimentos independentes.

A análise quantitativa da expressão gênica mostrou incremento da expressão de

FLK-1 e vWf nas CTTA mantidas em regime de SS (cerca de 2 e 4 vezes com relação às

CTTA em condição estática, respectivamente).

O gene que codifica para o receptor Notch também estava mais expresso nas CTTA mantidas sob SS que naquelas em condição estática (cerca de 4 vezes). 
Interessantemente não foi observada mudança na expressão do gene do ligante do receptor (jagged).

Expressão de Proteínas

A expressão de proteínas características de células endoteliais foi avaliada em CTTA submetidas ao "shear stress" (SS) através de citometria de fluxo (FACS).

Foi analisada a percentagem na população de CTTA das proteínas CD31 (PECAM-1 [Platelet Endothelial Cell Adhesion Molecule-1]) e FLK-1 (KDR/VEGFR2). Figura 27. 

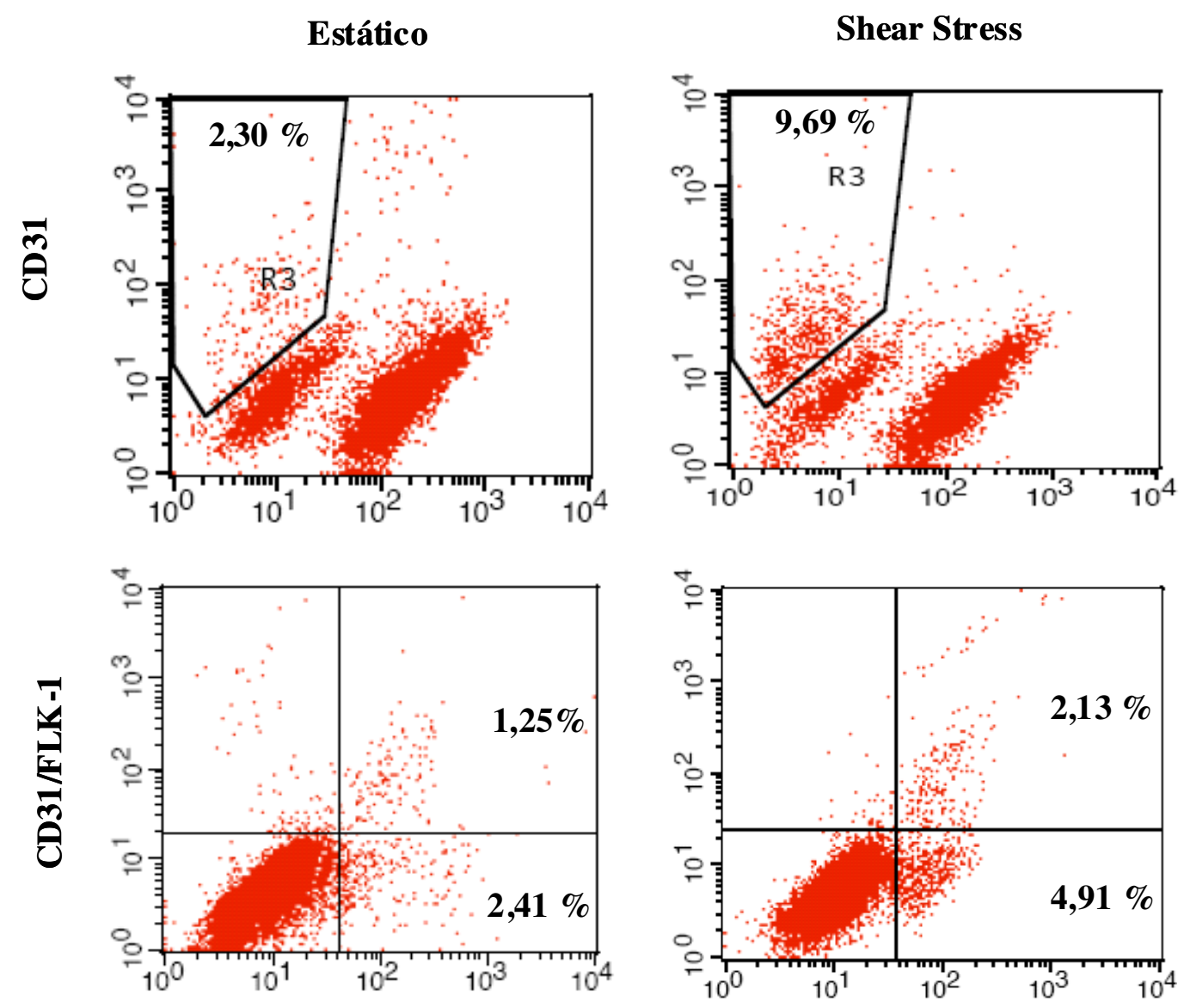

Figura 27. Citometria de fluxo de CTTA submetidas ao regime de "shear stress" (10dinas $\left./ \mathrm{cm}^{2}\right)$ e CTTA mantidas em condição estática. Os eixos em cada painel indicam a intensidade da fluorescência para cada um dos fluoróforos ligados aos anticorpos CD31 e FLK-1. O painel superior representa a análise da proteína CD31 e o painel inferior, a análise concomitante das proteínas CD31 e FLK-1. Os valores dentro das regiões delimitadas indicam a percentagem de CTTA que expressam os referidos marcadores.

A análise da população revelou que, após o estímulo com "shear stress", a expressão de CD31 e FLK-1 foi incrementada nas CTTA comparada à percentagem expressa pelas CTTA mantidas em condição estática [(CD31: 9,69\% vs. 2,30\% e 4,91\% vs. $2,41 \%$, respectivamente)]. Adicionalmente, a percentagem da população de CTTA expressando concomitantemente CD31 e FLK-1 foi maior nas células mantidas em 
regime de SS comparada às células mantidas em condição estática de meio de cultura $(2,13 \%$ vs. $1,25 \%)$.

\subsection{EFEITO DO “SHEAR STRESS” SOBRE A PRODUÇÃO DE VEGF E ÓXIDO NÍTRICO EM CÉLULAS-TRONCO DO TECIDO ADIPOSO}

Substâncias vasoativas importantes para a manutenção da homeostase vascular foram avaliadas nas CTTA submetidas ao "shear stress".

A produção de óxido nítrico (NO), um importante gás produzido pelas células endoteliais cuja ação direta nas células musculares lisas do vaso regula a vasodilatação, foi avaliado no meio de cultura das CTTA submetidas ou não ao "shear stress", através da determinação de um subproduto, o nitrito ( $\mathrm{NO}^{-}{ }^{-}$. Nitrito foi determinado no meio de cultura de CTTA submetidas ou não ao SS após 24, 48 e 72 horas do início do estímulo.

A produção de nitrito a cada hora foi incrementada nas CTTA mantidas sob o regime de fluxo laminar [24h: $0,19 \pm 0,04 \mu \mathrm{M} v s .0,02 \pm 0,00 \mu \mathrm{M} ; 48 \mathrm{~h}: 0,16 \pm 0,04 \mu \mathrm{M}$ vs. $0,02 \pm 0,00 \mu \mathrm{M}$; 72h: $0,17 \pm 0,05 \mu \mathrm{M}$ vs. $0,01 \pm 0,00 \mu \mathrm{M}(p<0,001)]$. Figura 28 . 


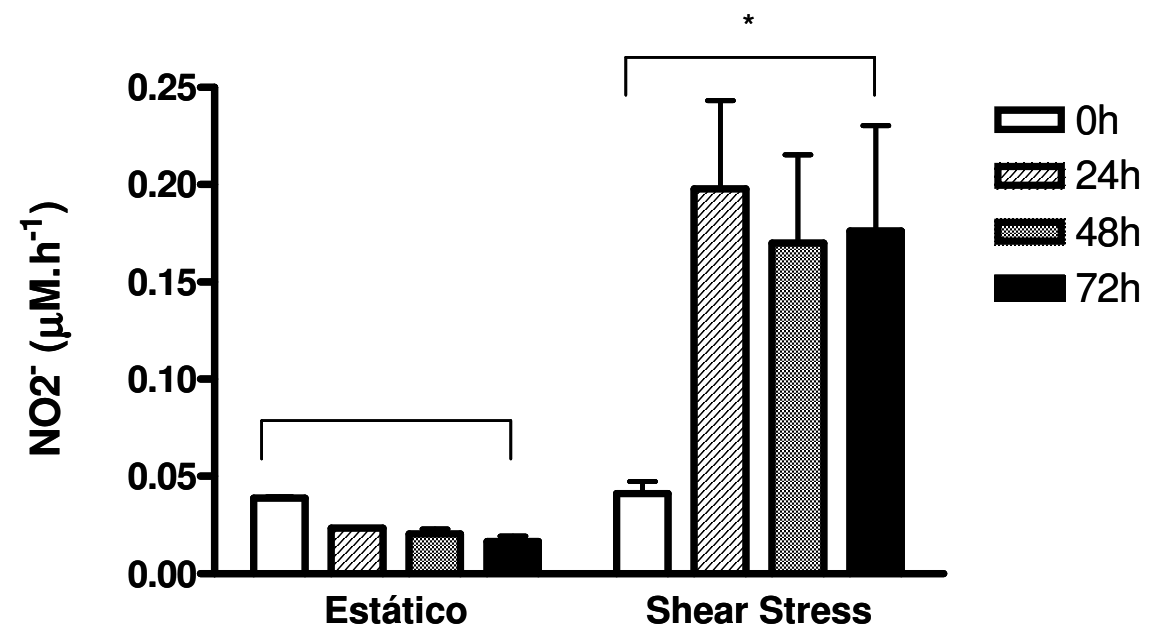

Figura 28. Produção de nitrito em CTTA submetidas ao "shear stress". Nitrito foi determinado no meio de cultura após 0, 24, 48 e 72 horas em CTTA submetidas ao SS e naquelas em condição estática. Valores expressos como média \pm EPM $(n=3$ experimentos) normalizados por hora. * indica diferença entre CTTA sob SS e CTTA em condição estática $(p<0,001)$. Valor $p$ obtido pela análise de variância ANOVA de 2 fatores.

A secreção do fator de crescimento VEGF foi também avaliada no meio de cultura das CTTA submetidas ao SS. Interessantemente, as CTTA mantidas em condição estática do meio de cultura apresentaram uma produção considerável de VEGF e o estímulo de SS não incrementou a expressão do fator nas CTTA em nenhum dos intervalos de tempo avaliados $[24 \mathrm{~h}(727,98 \pm 112,68 \mathrm{pg} / \mathrm{mL} v s .668,68 \pm 98,14 \mathrm{pg} / \mathrm{mL})$, 48h $(940,30 \pm 109,41 \mathrm{pg} / \mathrm{mL} v s .990,94 \pm 61,44 \mathrm{pg} / \mathrm{mL})$ e $72 \mathrm{~h}(1019,86 \pm 113,32 \mathrm{pg} / \mathrm{mL}$ vs.1238,97 $\pm 102,02$ pg/mL)]. Figura 29. 


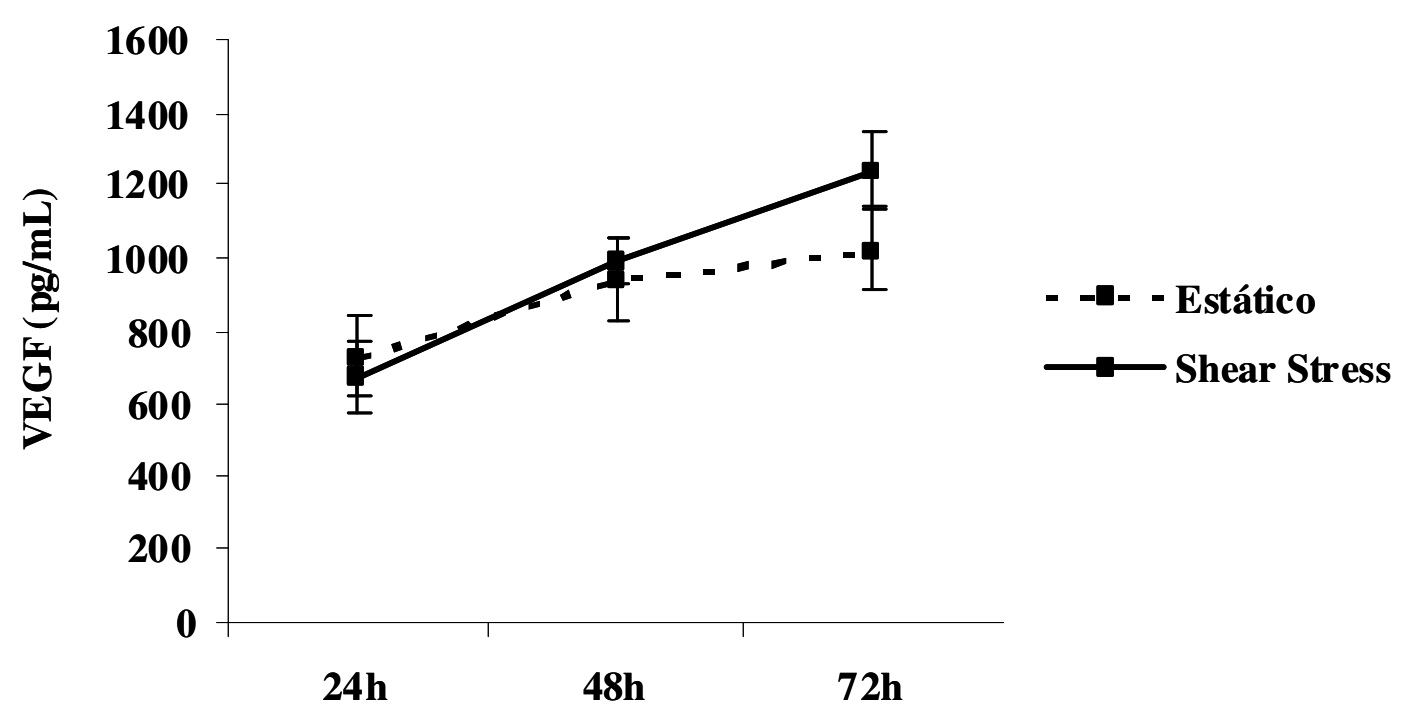

Tempo sob estímulo (h)

Figura 29. Produção de VEGF em CTTA submetidas ao "shear stress". VEGF foi determinado no meio de cultura após 24, 48 e 72 horas em CTTA submetidas ao SS (linha cheia) e naquelas em condição estática (linha tracejada). Os valores são expressos em média \pm EPM ( $\mathrm{n}=3$ experimentos).

\section{4 “SHEAR STRESS” PROMOVE A FORMAÇÃO DE ESTRUTURAS TUBULARES EM CÉLULAS-TRONCO DO TECIDO ADIPOSO}

A formação de estruturas tubulares em matriz de colágeno (matrigel) é uma característica funcional de células endoteliais. CTTA submetidas ao SS foram avaliadas quanto à capacidade de produzir estruturas similares quando mantidas em matrigel.

A figura 30 mostra que as CTTA aderiram na matriz de colágeno e, apenas aquelas submetidas previamente ao regime de SS foram capazes de formar túbulos similares aos observados nas células endoteliais, indicando que o SS induziu, sob esse aspecto, o comportamento de células endoteliais em CTTA. 

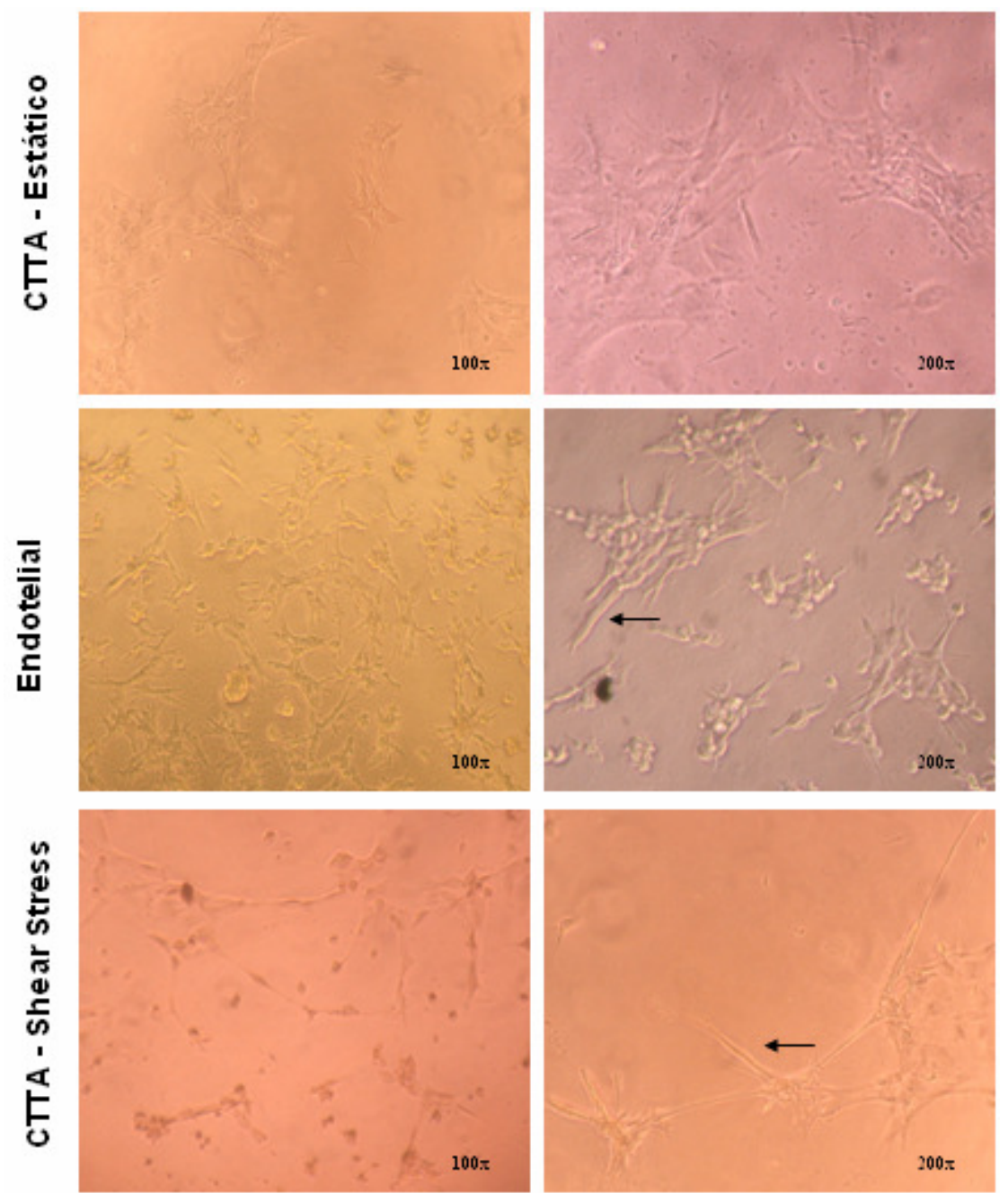

Figura 30. Efeito do SS sobre a formação de estruturas tubulares em matrigel. Imagens de microscopia óptica de contraste de fase em CTTA mantidas em condição estática de meio de cultura, células endoteliais e CTTA submetidas ao regime de SS. A seta indica a formação tubular observada apenas nas células endoteliais e nas CTTA estimuladas com SS. 


\section{$\begin{array}{llllll}\text { 4.5 EFEITO DAS CÉLULAS-TRONCO DO TECIDO ADIPOSO } & \text { DO }\end{array}$ PREVIAMENTE ESTIMULADAS COM “SHEAR STRESS" SOBRE O REPARO DO INFARTO DO MIOCÁRDIO EM RATOS}

Tendo em vista a abordagem de terapia celular para o tratamento do infarto do miocárdio, CTTA mantidas em regime de SS por 72 horas foram testadas quanto à capacidade de reparar estrutural e funcionalmente, o coração de ratos infartados.

\subsubsection{Avaliação Morfométrica - Tamanho do Infarto, Perímetro do Ventrículo Esquerdo e Espessura da Cicatriz}

A análise histológica dos corações infartados não mostrou diferença estatisticamente significativa no tamanho de infarto, medido pela percentagem média do perímetro do ventrículo esquerdo de colágeno transmural, entre os grupos avaliados [NT: $26,99 \pm 1,61 \%$; COL: $26,95 \pm 3,11 \%$; CTTA: $32,58 \pm 2,45 \%$; CTTA+SS: $31,14 \pm$ $2,52 \% ;(p=0.56)]$. Figura 31 a.

O remodelamento ventricular subseqüente ao infarto implica, entre outras coisas, na alteração da geometria da cavidade do VE (dilatação) e progressivo adelgaçamento da parede fibrótica. O perímetro do VE e da espessura da parede infartada foram avaliadas nesse estudo.

O perímetro do VE foi menor nos animais não-infartados comprados aos dos demais grupos [Sham: 27,50 $\pm 0,18 \mathrm{~mm} v s . \mathrm{NT}: 32,97 \pm 0,44 \mathrm{~mm}(p<0,001)$; COL: $29,73 \pm 0,72 \mathrm{~mm}(p<0,05)$; CTTA: $30,78 \pm 0,34 \mathrm{~mm}(p<0,001)$; CTTA+SS: 30,29 \pm 0,60 mm; $(p<0.001)]$. Figura 31 b. 
A cicatriz foi mais espessa nos animais injetados com CTTA estimuladas ou não com SS comparada à espessura observada nos animais infartados e não tratados [CTTA: $1,19 \pm 0,07 \mathrm{~mm}$ e CTTA+SS: $1,17 \pm 0,07 \mathrm{~mm} v s . \mathrm{NT}: 0,77 \pm 0,07 \mathrm{~mm}(p<0,05)]$. Adicionalmente, os menores valores de espessura da borda do infarto foram observados nos animais dos grupos NT e COL comparadas às medidas dos animais do grupo Sham (NT: $1,09 \pm 0,03 \mathrm{~mm}$ e COL: $1,15 \pm 0,03 \mathrm{~mm}$ vs. Sham: $1,57 \pm 0,11 \mathrm{~mm} ; p<0,01$ ). Figura $31 \mathrm{c}$ e d.

$\mathbf{A}$

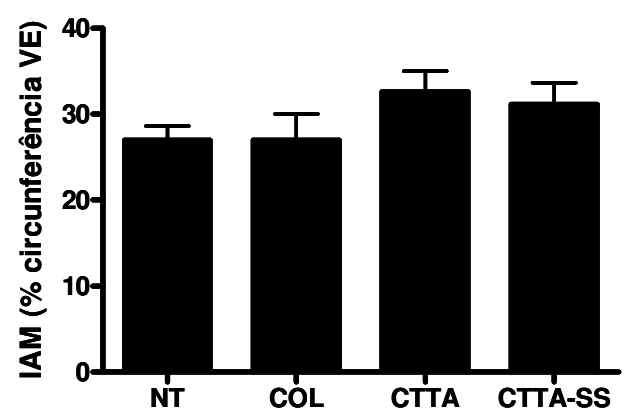

C

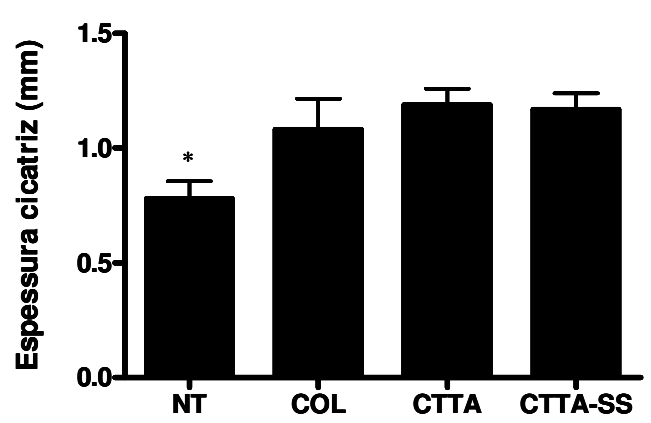

B

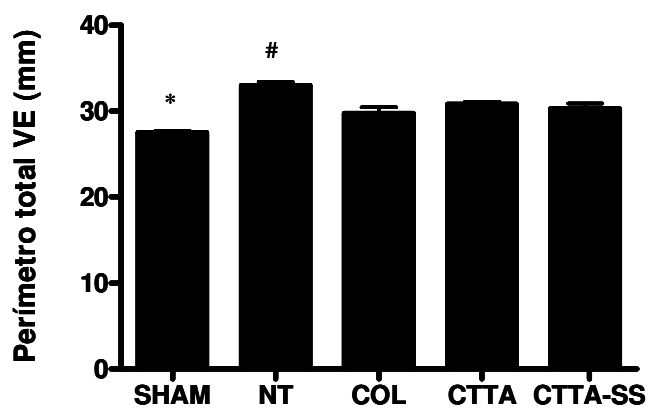

D

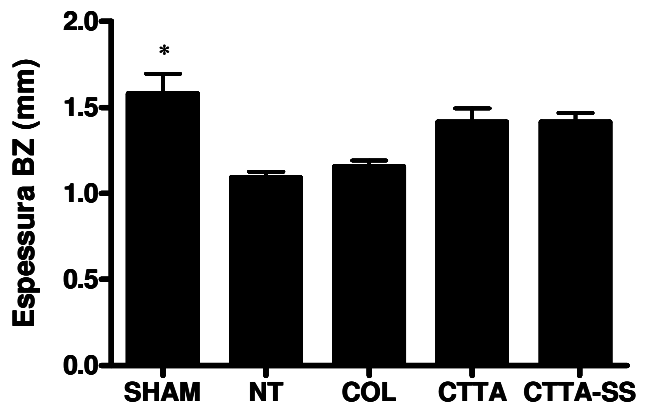

Figura 31. Morfometria dos corações de ratos infartados injetados com CTTA e os respectivos controles. Sham $(\mathrm{n}=$ 8), NT $(n=8)$, COL $(n=6)$, CTTA $(n=6)$ e CTTA+SS $(n=6)$ indicam, respectivamente, animais não infartados e não-tratados, infartados e com injeção intramiocárdica de meio de cultura DMEM, infartados e com injeção intramiocárdica de colágeno, infartados e com injeção intramiocárdica de CTTA e infartados e com injeção intramiocárdica de CTTA+SS. Os valores são expressos como média \pm EPM. Painel A: tamanho do infarto do miocárdio (IAM) em percentagem do perímetro do ventrículo esquerdo nos grupos estudados; painel B: perímetro total $(\mathrm{mm})$ da cavidade do VE nos grupos estudados (* indica diferença com o grupo NT $[p<0,001]$, COL $[p<0,05]$, CTTA $[p<0,001]$ e CTTA+SS $[p<0,001]$ e \# indica diferença com o grupo COL $[\mathrm{p}<0,01]$, CTTA [p $<0,05]$ e CTTA+SS $[p<0,01])$; painel C: espessura $(\mathrm{mm})$ da cicatriz do IAM $(*$ indica diferença com o grupo CTTA e CTTA+SS $[\mathrm{p}<0,05])$ e painel D: espessura da zona de borda $(\mathrm{BZ} \mathrm{em} \mathrm{mm})$ nos grupos estudados (* indica diferença com os grupos NT e COL $[\mathrm{p}<0,01])$. 


\subsubsection{Avaliação Hemodinâmica da Função Cardíaca - Medidas de Pressão Intraventricular, de Contratilidade e de Desempenho Cardíaco}

Avaliação em condições basais de experimentação

As alterações morfológico-estruturais que ocorrem após o infarto repercutem na contratilidade do músculo cardíaco e conseqüentemente na função do órgão. A avaliação hemodinâmica direta da função ventricular foi realizada nos ratos estudados, no estado basal e durante o aumento súbito na pós-carga. A tabela 8 mostra os valores obtidos dos parâmetros hemodinâmicos analisados nos animais do presente estudo.

De maneira geral, os parâmetros hemodinâmicos avaliados no estado basal mostraram diferença estatisticamente significativa apenas entre os animais nãoinfartados (sham) e os infartados não-tratados (NT), ou seja, entre os extremos.

Por outro lado, a análise hemodinâmica durante o aumento súbito na pós-carga permitiu a observação de perfis de comportamento intermediários, em termos de função cardíaca, observados nos animais tratados com CTTA. Os parâmetros foram analisados com base no comportamento hemodinâmico basal dos animais. 


\begin{tabular}{|c|c|c|c|c|c|c|}
\hline & $\begin{array}{c}\text { Sham } \\
n=8\end{array}$ & $\begin{array}{c}\text { NT } \\
n=8\end{array}$ & $\begin{array}{l}\text { COL } \\
n=6\end{array}$ & $\begin{array}{c}\text { CTTA } \\
n=6\end{array}$ & $\begin{array}{c}\text { CTTA+SS } \\
n=6\end{array}$ & Valor $p$ \\
\hline PDfVE (mm Hg) & $4,37 \pm 1,13 *$ & $13 \pm 1,50 *$ & $11,83 \pm 3,19$ & $9,66 \pm 2,30$ & $5,83 \pm 1,19$ & 0,01 \\
\hline PSVE (mm Hg) & $117,90 \pm 4,34$ & $114,70 \pm 6,36$ & $115,50 \pm 3,22$ & $118,20 \pm 2,75$ & $111,80 \pm 5,31$ & 0,85 \\
\hline$+\mathrm{dP} / \mathrm{dt}_{\text {máx }}\left(\mathrm{mm} \mathrm{Hg} . \mathrm{s}^{-1}\right)$ & $9735 \pm 477 *$ & $7199 \pm 331 *$ & $8072 \pm 415$ & $7954 \pm 411$ & $8331 \pm 892$ & 0,04 \\
\hline$-\mathrm{dP} / \mathrm{dt}_{\operatorname{máx}}\left(\mathrm{mm} \mathrm{Hg} \cdot \mathrm{s}^{-1}\right)$ & $-6765 \pm 373 *$ & $-5133 \pm 178 *$ & $-5691 \pm 354$ & $-5435 \pm 451$ & $-5215 \pm 507$ & 0,03 \\
\hline $\mathrm{FC}(\mathrm{bpm})$ & $361 \pm 27,46$ & $328 \pm 11,61$ & $374 \pm 20,19$ & $371 \pm 4,15$ & $357 \pm 20,37$ & 0,44 \\
\hline $\mathrm{IC}\left(\mathrm{mL} \cdot \mathrm{min}^{-1} / \mathrm{kg}\right)$ & $204,40 \pm 21,53$ & $216,20 \pm 14,67$ & $210,70 \pm 19,02$ & $181,40 \pm 37,20$ & $117,90 \pm 19,12$ & 0,58 \\
\hline IVS (mL.bat ${ }^{-1} / \mathrm{kg}$ ) & $0,50 \pm 0,04$ & $0,71 \pm 0,06$ & $0,59 \pm 0,06$ & $0,48 \pm 0,10$ & $0,52 \pm 0,05$ & 0,31 \\
\hline ITS (gm.min ${ }^{-1} / \mathrm{kg}$ ) & $0,89 \pm 0,08$ & $0,92 \pm 0,07$ & $0,80 \pm 0,08$ & $0,70 \pm 0,14$ & $0,71 \pm 0,08$ & 0,07 \\
\hline
\end{tabular}

Tabela 8. Parâmetros hemodinâmicos basais obtidos por avaliação direta (média \pm EPM). Pressão diastólica final do ventrículo esquerdo (PDfVE), pressão sistólica do ventrículo esquerdo (PSVE), freqüência cardíaca (FC), taxa máxima de pressão alcançada $\left(+\mathrm{dP}_{\mathrm{de}} \mathrm{dt}_{\text {máx }}\right)$ e mínima (-dP/dt máx), índice cardíaco (IDC), índice do volume sistólico (IVS) e índice do trabalho sistólico (ITS). Valor $p$ obtido através da análise ANOVA 1 via (pós-teste Tukey). * indica os grupos estatisticamente diferentes. 
Avaliação durante o aumento súbito da pressão

\section{Pressão diastólica final e pressão sistólica}

A pressão diastólica final do VE (PDfVE) quando aumentada indica incapacidade do ventrículo de ejetar com efetividade o volume de sangue pertinente durante a diástole. Os maiores incrementos na PDf foram observados nos animais dos grupos NT e COL. Por outro lado, as menores mudanças foram observadas nos animais dos grupos sham comparados aos dos grupos NT e COL $(1,75 \pm 0,25 \%$ vs. $22,35 \pm 3,07 \% ; p<0,001$ e $17,33 \pm 2,60 \% ; \mathrm{p}<0,01$, respectivamente). A mudança na PDf também foi menor nos animais dos grupos CTTA e CTTA+SS comparados aos animais não-tratados $(10,83 \pm 4,67 \%$ e $8,00 \pm 0,85 \%$ vs. $22,35 \pm 3,07 \% ; p<$ 0,05 e 0,01 , respectivamente). Figura 32 .

Com relação à pressão sistólica (PS) não foi observada diferença estatisticamente significativa entre os grupos $(p=0,17)$. A freqüência cardíaca não foi diferente entre os animais, esse dado já era esperado uma vez que foi realizada a vagotomia bilateral em todos os animais estudados $(p=0,44)$. Figura 33 . 


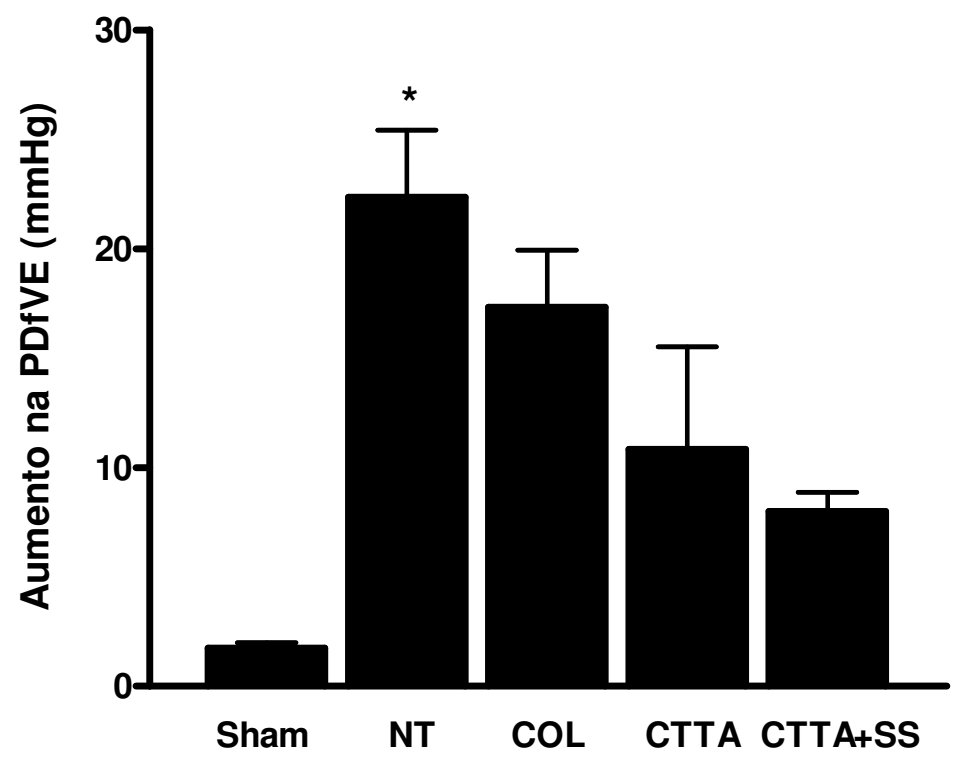

Figura 32. Aumento na PDfVE nos diferentes grupos experimentais. Os valores são expressos como média \pm EPM do aumento na PDf em $\mathrm{mm} \mathrm{Hg}$ nos grupos estudados. Sham $(\mathrm{n}=8)$, NT $(\mathrm{n}=8), \operatorname{COL}(\mathrm{n}=6)$, CTTA $(n=6)$ e CTTA+SS $(n=6)$ indicam, respectivamente, animais não infartados e nãotratados, infartados e com injeção intramiocárdica de meio de cultura DMEM, infartados e com injeção intramiocárdica de colágeno, infartados e com injeção intramiocárdica de CTTA e infartados e com injeção intramiocárdica de CTTA+SS. 


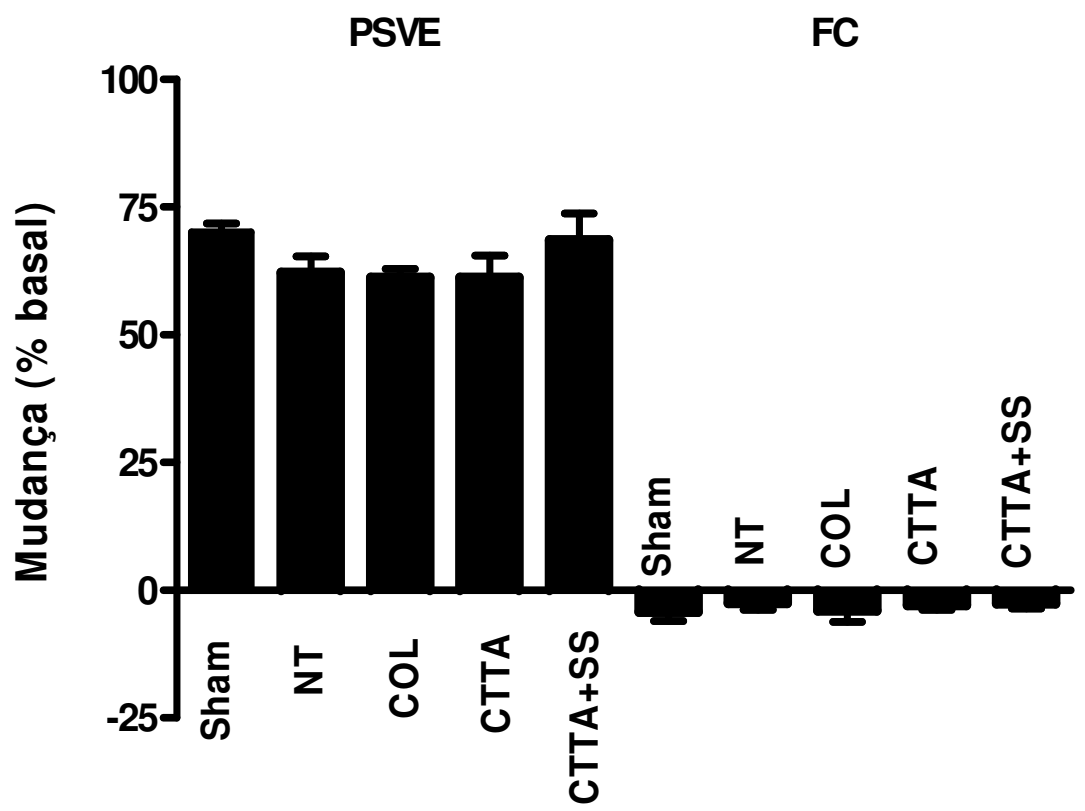

Figura 33. Aumento na PDf nos diferentes grupos experimentais. Os valores são expressos como média \pm EPM do aumento na PDf em $\mathrm{mm} \mathrm{Hg}$ nos grupos estudados. Sham (n $=8)$, NT $(n=8)$, COL $(n=6)$, CTTA $(n=6)$ e CTTA+SS $(n=$ 6) indicam, respectivamente, animais não infartados e nãotratados, infartados e com injeção intramiocárdica de meio de cultura DMEM, infartados e com injeção intramiocárdica de colágeno, infartados e com injeção intramiocárdica de CTTA e infartados e com injeção intramiocárdica de CTTA+SS.

\section{Medidas de contratilidade}

As variações máximas na pressão no ventrículo esquerdo durante a sístole e diástole refletem, essencialmente, a capacidade contrátil do ventrículo.

A mudança relativa ao estado basal na $+\mathrm{dP} / \mathrm{dt}_{\text {máx }}$, foi maior nos animais dos grupos sham, CTTA e CTTA+SS comparados às medidas obtidas nos animais dos grupos NT e COL $[(45,50 \pm 5,69 \%, 51,50 \pm 14,41 \%$ e $52,00 \pm 14,22 \%$ vs. $22,03 \pm$ $6,55 \%$ e $15,40 \pm 6,05 \%(p=0,03)$ respectivamente], mostrando maior capacidade contrátil nesses animais. Figura 34. 


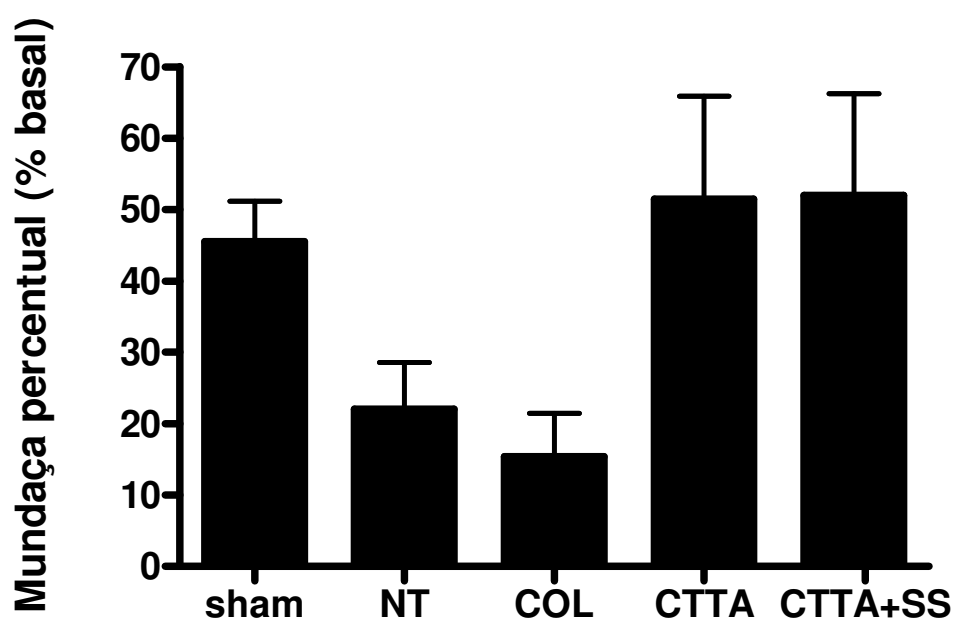

Figura 34. Mudança percentual na $+d P / d t_{\text {máx }}$. Os valores são expressos como média \pm EPM do aumento na $+\mathrm{dP} / \mathrm{dt}_{\text {máx }}$ relativa às medidas nos estado basal nos grupos estudados. Sham $(\mathrm{n}=8)$, NT $(\mathrm{n}=8), \operatorname{COL}(\mathrm{n}=$ $6)$, CTTA $(n=6)$ e CTTA+SS $(n=6)$ indicam, respectivamente, animais não infartados e nãotratados, infartados e com injeção intramiocárdica de meio de cultura DMEM, infartados e com injeção intramiocárdica de colágeno, infartados e com injeção intramiocárdica de CTTA e infartados e com injeção intramiocárdica de CTTA+SS.

\section{$\underline{\text { Medidas de desempenho cardíaco }}$}

A avaliação das medidas de desempenho cardíaco mostrou que os animais tratados com CTTA submetidas ou não ao SS tiveram um desempenho satisfatório, similar ao de animais não-infartados, com relação ao índice cardíaco, índice do volume sistólico ejetado e índice do trabalho sistólico.

O índice cardíaco diminuiu relativamente mais nos animais dos grupos NT e COL comparados aos animais dos grupos sham $(-56,68 \pm 2,41 \%$ e $-55,83 \pm 3,86 \%$ vs. $-22,88 \pm 5,32 \% ; p<0,001$, respectivamente). Similar diferença na mudança do 
índice cardíaco foi observada quando as medidas dos grupos NT e COL foram comparadas às dos animais dos grupos CTTA $(-56,68 \pm 2,41 \%$ e $-55,83 \pm 3,86 \%$ vs. $-25,17 \pm 6,81 \% ; p<0,001$ e 0,$01 ;$ respectivamente). Adicionalmente, a queda percentual do índice cardíaco foi maior nos animais dos grupos NT e COL comparados aos animais do grupo CTTA+SS $(-56,68 \pm 2,41 \%$ e $-55,83 \pm 3,86 \%$ vs. $-24,17 \pm 5,63 \% ; p<0,001$ e 0,01 , respectivamente).

O índice do volume sistólico ejetado apresentou padrão muito similar ao observado para o índice cardíaco. Os animais dos grupos NT e COL atingiram uma queda percentual maior no índice do volume sistólico ejetado que os animais dos grupos sham, CTTA e CTTA+SS, respectivamente $[-53,79 \pm 2,55 \%$ e $-54,17 \pm 3,87$ $\%$ vs. $-19,25 \pm 5,59 \%(\mathrm{p}<0,001) ;-23,00 \pm 6,83 \%(\mathrm{p}<0,01)$ e $-22,00 \pm 5,24 \%(\mathrm{p}<$ $0,001$ e 0,01$)]$.

O aumento súbito na pós-carga provocou aumento na geração de trabalho apenas nos animais dos grupos sham, CTTA e CTTA+SS. Nesses animais houve um aumento de cerca de $30 \%$ do índice de geração de trabalho na condição de pós-carga, diferentemente da queda na geração de trabalho observada nos animais NT e COL. Assim, o aumento na geração de trabalho foi observado apenas nos animais dos grupos sham, CTTA e CTTA+SS comparado aos animais dos grupos NT e COL $[42,75 \pm 9,30 \%, 22,67 \pm 13,43 \%$ e $30,67 \pm 12,06 \%$ vs. $-35,56 \pm 4,73 \%(p<0,001)$ e $-31,67 \pm 6,21 \%(0,01)$, respectivamente]. Figura 35 . 


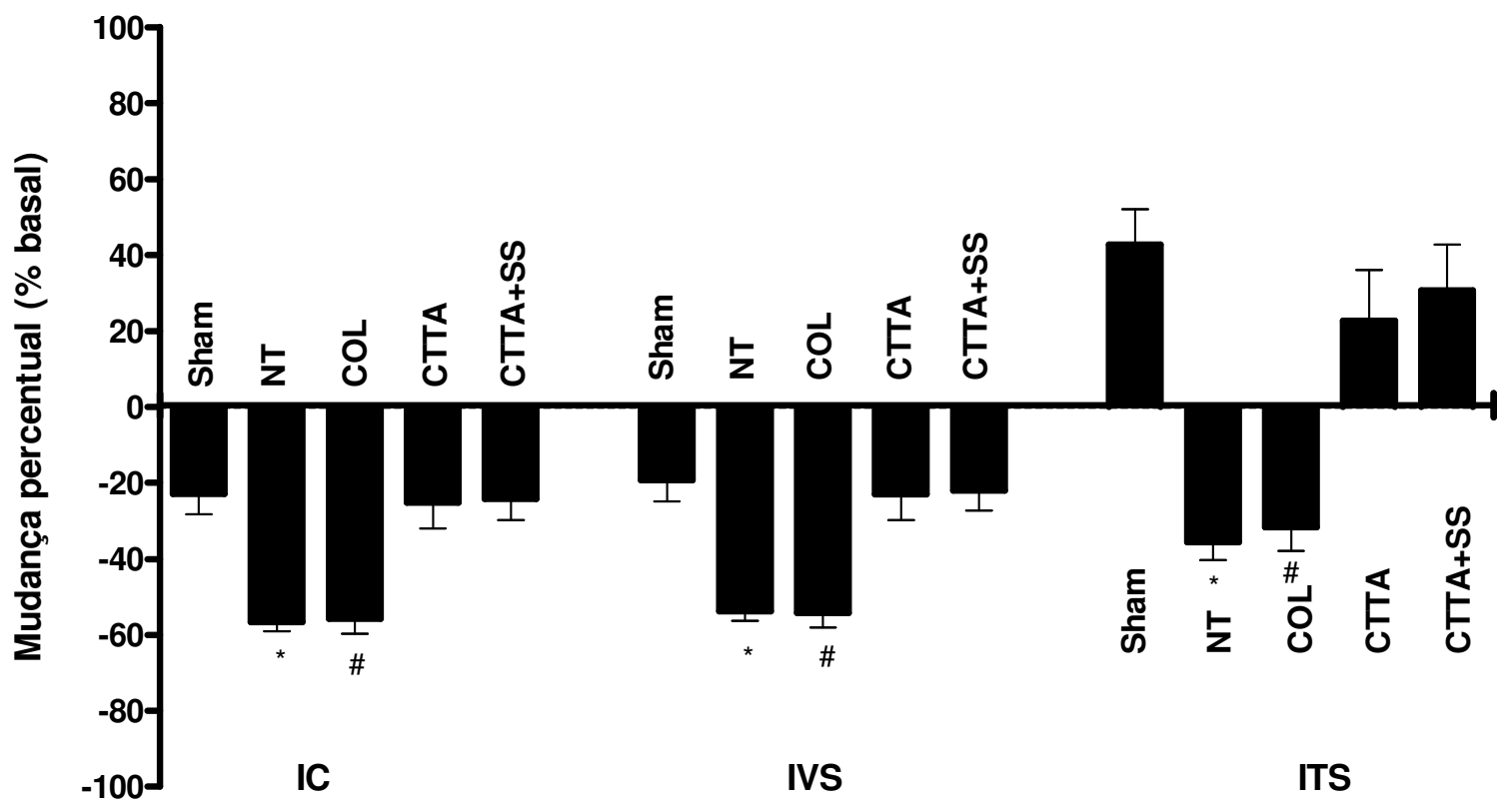

Figura 35. Mudança percentual no índice cardíaco (IC), índice do volume sistólico ejetado (IVS) e índice do trabalho sistólico (ITS) durante o aumento na pós-carga. Os valores são relativos aos mesmos parâmetros no estado basal (\% basal) e representam a média \pm EPM. Sham $(n=8)$, NT $(n=$ 8), COL $(n=6)$, CTTA $(n=6)$ e CTTA+SS $(n=6)$ indicam, respectivamente, animais não infartados e não-tratados, infartados e com injeção intramiocárdica de meio de cultura DMEM, infartados e com injeção intramiocárdica de colágeno, infartados e com injeção intramiocárdica de CTTA e infartados e com injeção intramiocárdica de CTTA+SS. * e \# indicam diferença com os grupos sham, CTTA e CTTA+SS.

Dados individuais da geração de trabalho e função do aumento na pressão sistólica estão apresentados individualmente na figura 14 em análises de regressão linear. Nota-se que a geração de trabalho aumentou em função do aumento na PS apenas nos animais dos grupos SHAM, CTTA e CTTA+SS. 


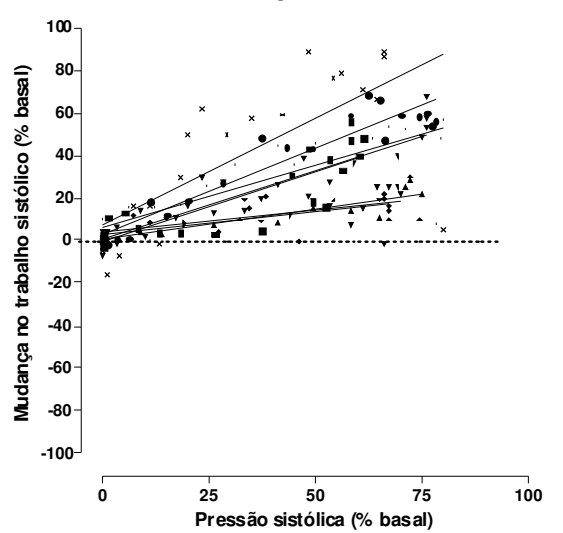

NT

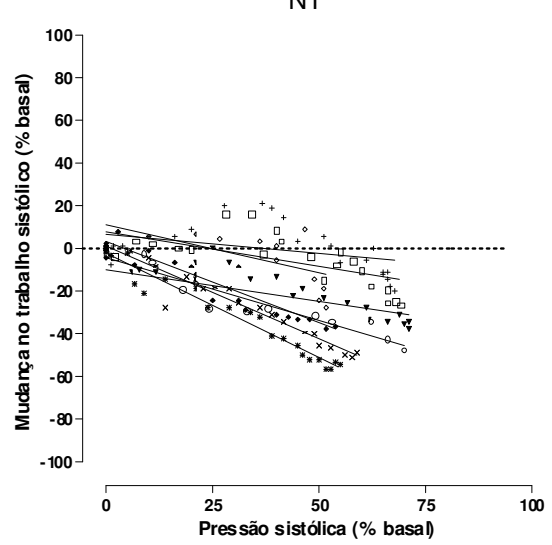

$\mathrm{COL}$

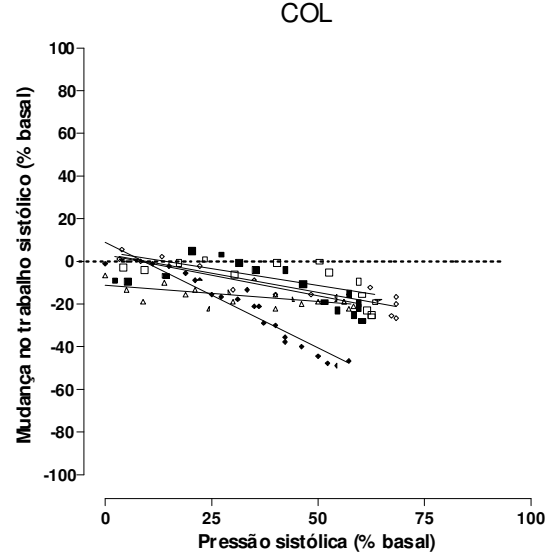

CTTA

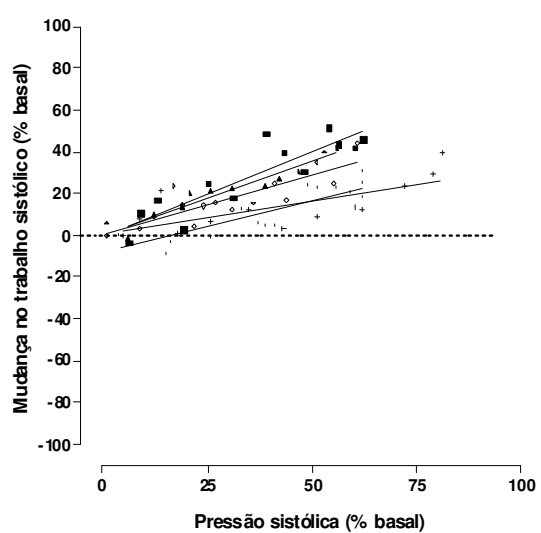

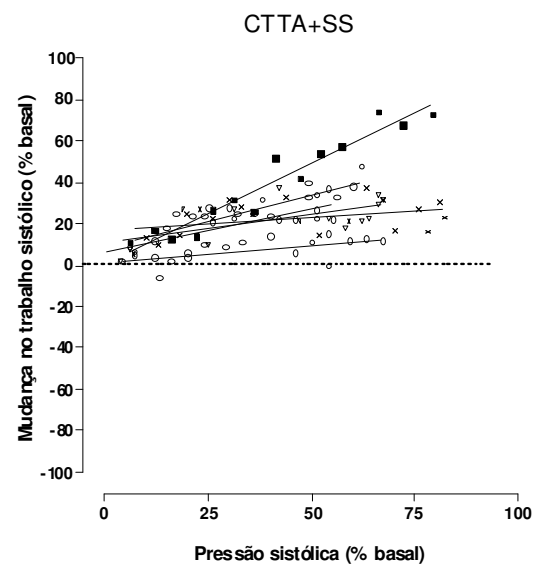

Figura 36. Regressão linear da mudança na geração de trabalho sistólico em função do aumento na pós-carga. As retas representam as regressões lineares das mudanças observadas no trabalho sistólico em função do aumento relativo da pós-carga em cada animal. SHAM $(n=8)$, NT $(n=8)$, COL $(n=6)$, CTTA $(n=6)$, CTTA $(n=6)$ e CTTA+SS $(n=6)$ indicam, respectivamente, animais não infartados e não-tratados, infartados e com injeção intramiocárdica de meio de cultura DMEM, infartados e com injeção intramiocárdica de colágeno, infartados e com injeção intramiocárdica de CTTA e infartados e com injeção intramiocárdica de CTTA+SS. 


\subsection{CÉLULAS-TRONCO DO TECIDO ADIPOSO INJETADAS NO CORAÇÃO INFARTADO EXPRESSAM MARCADORES DE CÉLULAS ENDOTELIAIS IN VIVO}

A presença das CTTA injetadas no coração foi avaliada através da identificação de células positivas para o marcador fluorescente DiL. CTTA foram observadas nos corações dos animais expressando as proteínas FLK-1 (figura 37 a, b) e vWf (figura 38 a, b). De maneira interessante, a expressão de tais proteínas foi observada igualmente nas CTTA submetidas ao SS e também naquelas mantidas em condição estática do meio de cultura. 


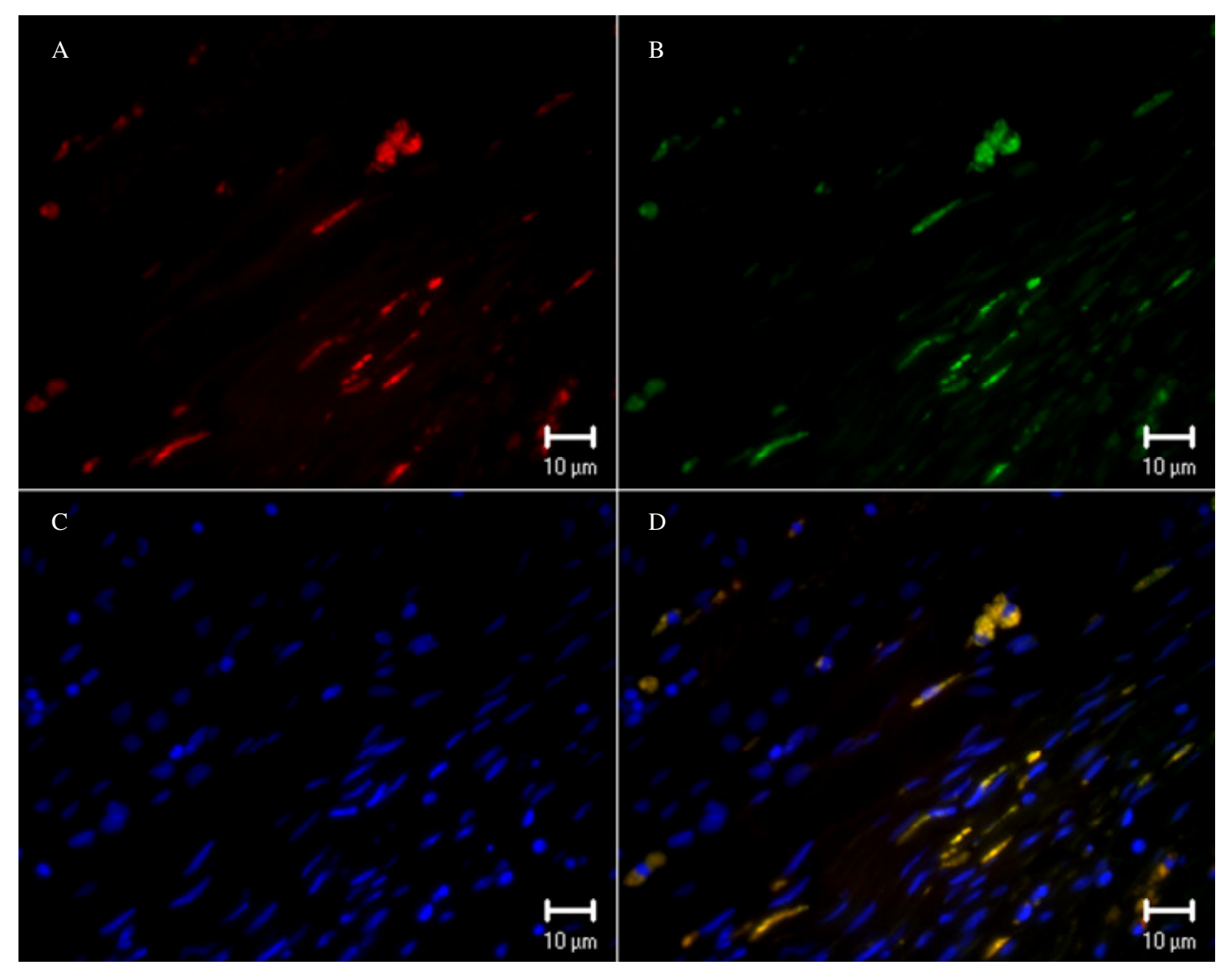

Figura 37 a. Microscopia óptica de fluorescência em secções histológicas de corações de ratos infartados tratados com CTTA previamente submetidas ao "shear stress" (CTTA+SS). O painel A (200x) ilustra as CTTA em vermelho (DiL), $B(200 x)$ a proteína FLK-1 em verde, $C$ (200x) núcleos celulares marcados em azul (DAPI), D (200x) a co-localização das imagens mostrando as CTTA expressando FLK-1 (amarelo). 


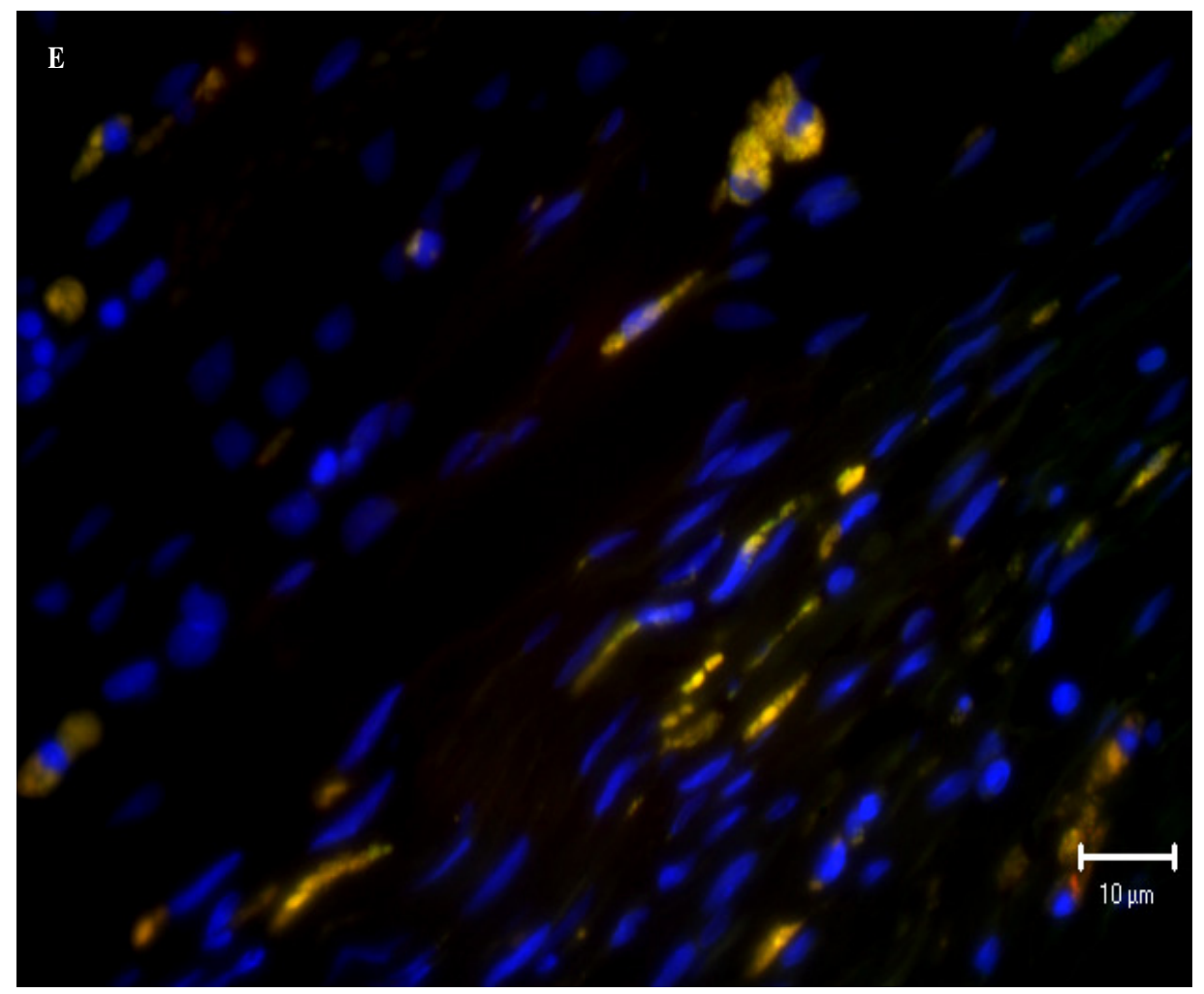

Figura 37 b. Microscopia óptica de fluorescência. $E$ (400x) representa a co-localização das imagens mostrando as CTTA expressando FLK-1 (amarelo). 


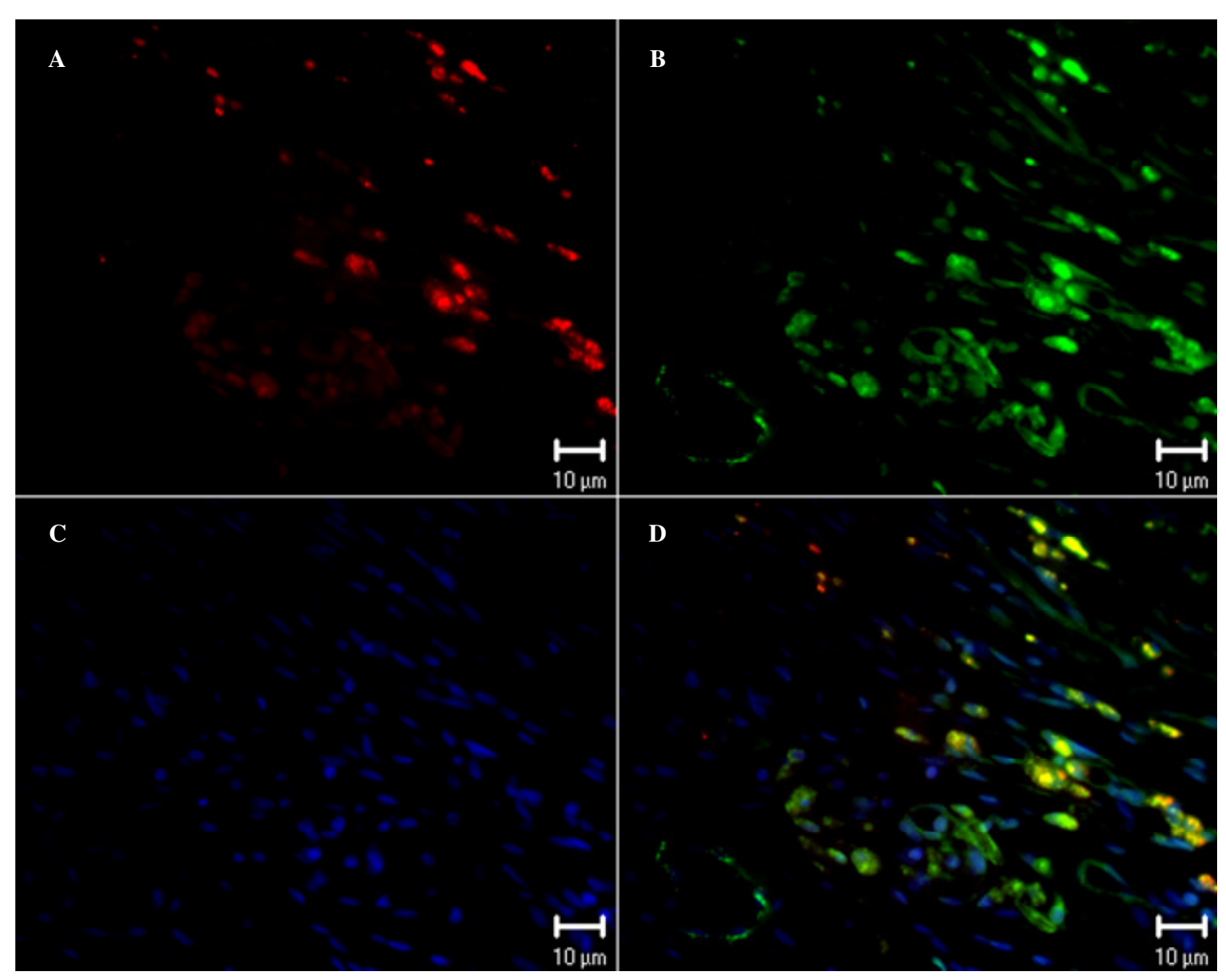

Figura 38 a. Microscopia óptica de fluorescência em secções histológicas de corações de ratos infartados tratados com CTTA previamente submetidas ao "shear stress" (CTTA+SS). O painel $A$ (200x) ilustra as CTTA em vermelho (DiL), $B(200 x)$ a proteína vWf em verde, $C$ (200x) núcleos celulares marcados em azul (DAPI), $D(200 x)$ e $E(400 x)$ a co-localização das imagens mostrando as CTTA expressando FLK-1. 


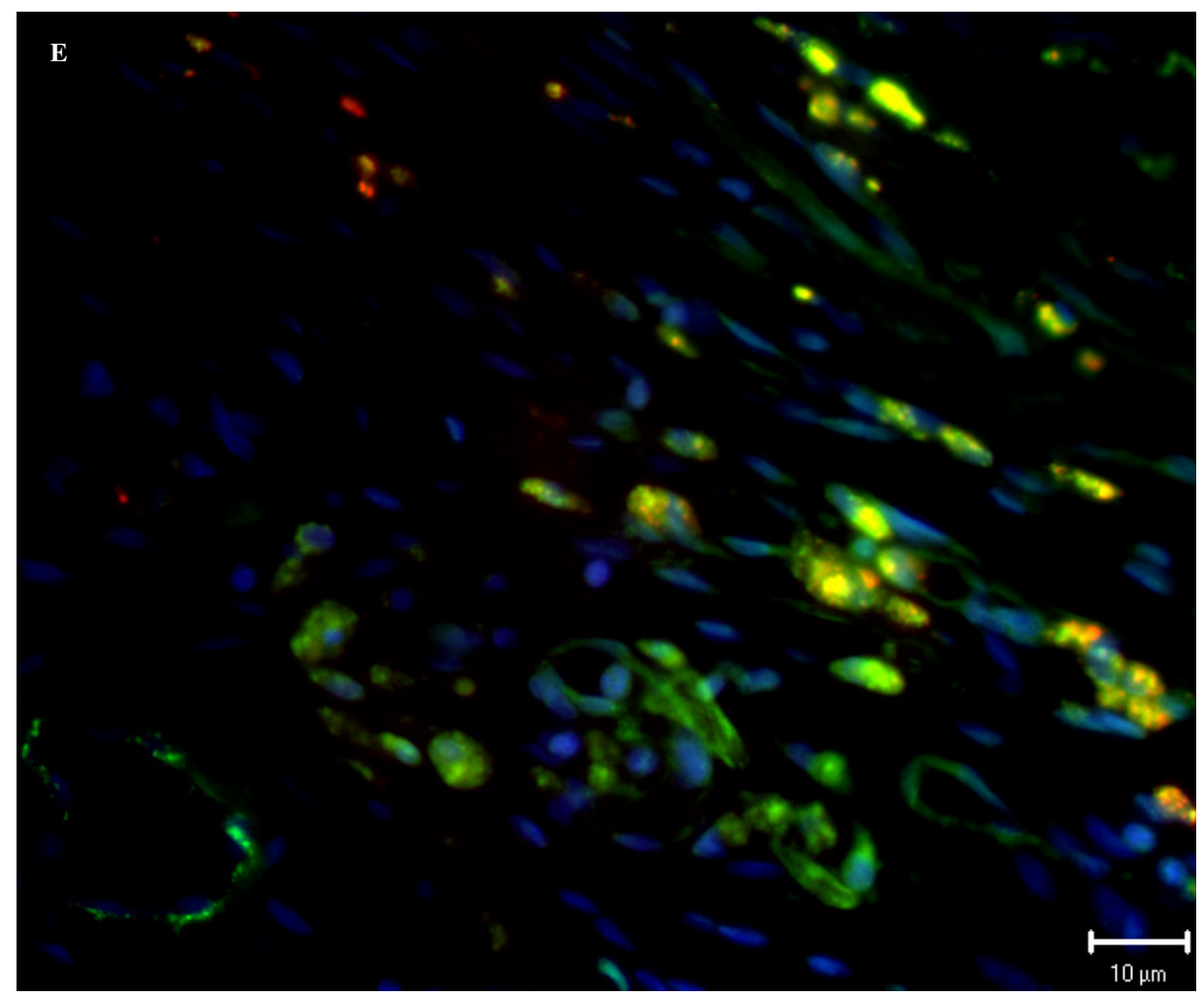

Figura 38 b. Microscopia óptica de fluorescência. $E$ (400x) representa a co-localização das imagens mostrando as CTTA expressando vWf (amarelo).

Futuras análises serão necessárias para a avaliação quantitativa da expressão dessas e outras proteínas assim como o esclarecimento do (s) mecanismo (s) envolvido nos efeitos observados após o uso de CTTA. 
O presente estudo mostrou que as CTTA de roedores são sensíveis à estimulação ex vivo com "shear stress" (SS). Estudos prévios demonstraram a diferenciação de células-tronco embrionárias, linhagens de células mesenquimais e até células musculares lisas em células endoteliais através do uso de "shear stress" 110-114.

As respostas das CTTA ao "shear stress" incluíram mudança na morfologia, incremento na expressão das proteínas CD31, FLK-1 e VWf, indução da síntese de óxido nítrico (NO) e capacidade de formar estruturas tubulares em matrigel.

Interessantemente, a produção de VEGF não mudou nas CTTA mantidas no regime de fluxo laminar. Cabe ressaltar que as CTTA mesmo em condições estáticas do meio de cultura, produziram VEGF em níveis consideráveis. O fator de crescimento VEGF e outras citocinas são conhecidamente expressos por células mesenquimais da medula óssea e células-tronco do tecido adiposo humano ${ }^{101 ; 102}$. Curiosamente, segundo dados de nosso laboratório, os níveis da proteína VEGF detectados nesse estudo com CTTA de roedores mantidas em regime de "shear stress" são superiores àqueles secretados por CTTA humanas nas mesmas condições.

Uma hipótese para explicar a ausência de incremento na produção de VEGF em CTTA submetidas ao SS pode estar relacionada à via de sinalização responsável pela produção desse fator. Segundo estudo do grupo de Yamamoto a diferenciação de célulastronco embrionárias em células endoteliais é mediada pela fosforilação de receptores FLK-1, porém independentemente da ação do VEGF ${ }^{110}$. Outros ligantes como o notch 
podem explicar a ativação de FLK-1 e os efeitos pós-transcricionais dessa sinalização 121. Além disso, a via de sinalização notch, através da ação direta em receptores para VEGF, é fundamental para a embriogênese do sistema vascular ${ }^{122-124}$. Nesse estudo a expressão do gene notch foi incrementada nas CTTA mantidas em regime de SS.

O maior objetivo desse estudo foi testar a hipótese do uso de "shear stress" como indutor da diferenciação de CTTA em células endoteliais para o uso em protocolo experimental de terapia celular em infarto.

Do ponto de vista histopatológico, os animais tratados com CTTA não apresentaram diferença com relação ao tamanho do infarto, porém, é importante salientar que todos os animais desse estudo foram selecionados, exatamente sob o critério de tamanho de infarto. Nós utilizamos animais com IAM entre 30 e $40 \%$ de fibrose transmural na parede anterior do VE. Esse critério foi adotado devido à estreita relação entre o tamanho de IAM e a função cardíaca. Nossos resultados mostraram que a terapia com CTTA estimuladas ou não com SS não alterou nem impediu a extensão do infarto, porém, amenizou o remodelamento subseqüente à isquemia. Nossos dados mostraram redução do perímetro do VE e maior espessura da cicatriz de colágeno nos animais tratados com CTTA. Uma cicatriz mais complacente e "celular" pode explicar a atenuação da dilatação do VE e, conseqüentemente, os efeitos observados sobre a função cardíaca desses animais.

A avaliação hemodinâmica durante a sobrecarga pressórica foi um importante instrumento para a análise da função contrátil ventricular. No estado, de maneira geral, 
as diferenças eram observadas apenas entre os extremos; os animais não-infartados e os infartados não-tratados. As medidas durante a sobrecarga mostraram perfis intermediários apresentados pelos animais tratados com CTTA submetidas ou não ao SS. Como esperado, os animais não infartados tiveram uma ligeira queda no volume sistólico e débito cardíaco, porém aumentaram a geração de trabalho frente à nova condição pressórica. Interessantemente, os animais tratados com CTTA apresentaram a mesma resposta, por outro lado, não observamos diferenças em nenhum parâmetro avaliado sob qualquer condição entre os animais tratados com CTTA e CTTA+SS.

Finalmente, nas CTTA identificadas nos corações dos animais foi observada a expressão de FLK-1 e VWf. Novamente, esse fenômeno foi observado nos dois grupos tratados com CTTA.

A presença dessas células pode ser interpretada sob vários aspectos. Do ponto de vista de ação direta, essas células podem estar numa fase de transição para o fenótipo de células endoteliais e formação de novos capilares, otimizando a perfusão da área isquêmica.

Ainda considerando a ação direta dessas células, uma observação interessante foi a organização das CTTA no tecido cardíaco; segundo as análises histológicas, essas células se distribuíram no miocárdio de maneira similar à organização das fibras cardíacas, fusiformes. Outro papel que pode ser sugerido para essas células, é a ação indireta através da secreção de fatores anti-apoptóticos e pró-angiogênicos cuja ação estaria relacionada às células isquêmicas cardíacas. 
Contudo, análises futuras deverão ser realizadas para a compreensão dos mecanismos envolvidos nos efeitos obtidos com CTTA em modelo animal de infarto.

Em conjunto, os dados desse estudo sugerem que as CTTA respondem ao estímulo de "shear stress" e que os efeitos positivos obtidos com uso dessas células sobre o remodelamento e função cardíaca de ratos infartados, a priori, estão relacionados em maior magnitude às próprias CTTA que as modificações promovidas pelo "shear stress". 
Com base nos achados desse estudo, pode-se concluir que:

- As CTTA podem ser expandidas ex vivo com relativa homogeneidade imunofenotípica;

- CTTA são capazes de se diferenciar em adipócitos e osteócitos quando estimuladas especificamente com meios de cultura apropriados;

- CTTA são responsivas ao "shear stress"; quando mantidas em regime de SS por 72 horas expressam proteínas relacionadas ao fenótipo endotelial - FLK-1, CD31 e vWf - e também genes relacionados à diferenciação celular - notch e jagged. Adicionalmente produzem óxido nítrico (NO) e VEGF, compatíveis com a função de células endoteliais;

- Em ratos infartados, as CTTA injetadas atenuam o remodelamento ventricular, através da promoção do aumento da espessura da cicatriz e amenização da dilatação da cavidade do VE;

- A deterioração da função cardíaca de ratos infartados, em especial a função contrátil do VE, pode ser recuperada através do uso de CTTA submetidas ou não previamente ao regime de shear stress. 
82. Freshney IR. Culture of animal cells: a manual basic technique. 4th edition, 2000.

83. Ding AH, Nathan CF, Stuehr DJ. Release of reactive nitrogen intermediates and reactive oxygen intermediates from mouse peritoneal macrophages. Comparison of active cytokines and evidence for independent production. J Immunol. 1988;141:2047-12.

84. Ivanović V, Jelkić N, Bikicki M, Petrović M, Canji T, Srdanović I.The significance of coronary collateral circulation in the preservation of myocardial function. Med Pregl. 2007; (5-6):287-91.

85. Regieli JJ, Jukema JW, Nathoe HM, Zwinderman AH, Ng S, Grobbee DE, van der Graaf Y, Doevendans PA.Coronary collaterals improve prognosis in patients with ischemic heart disease. Int J Cardiol 2008.

86. Shintani S, Murohara T, Ikeda H, Ueno T, Honma T, Katoh A, Sasaki K, Shimada T, Oike Y, Imaizumi T. Mobilization of endothelial progenitor cells in patients with acute myocardial infarction. Circulation 2001; 103(23):2776-9.

87. Gill M, Dias S, Hattori K, Rivera ML, Hicklin D, Witte L, Girardi L, Yurt R, Himel H, Rafii S. Vascular trauma induces rapid but transient mobilization of VEGFR2(+)AC133(+) endothelial precursor cells. Circ Res. 2001;88(2):167-74.

88. Aicher A, Brenner W, Zuhayra M, Badorff C, Massoudi S, Assmus B, Eckey T, Henze E, Zeiher AM, Dimmeler S. Assessment of the tissue distribution of transplanted human endothelial progenitor cells by radioactivity labeling. Circulation 2003; 107:2134-2139. 
89. Wu JC, Chen IY, Wang Y, Tseng JR, Chhabra A, Salek M, Min J, Fishbein MC, Crystal R, Gambhir SS. Molecular imaging of the kinetics of vascular endothelial growth factor gene expression in ischemic myocardium. Circulation 2004; 110:685-691.

90. Wang X, Zhang G, Jin H, Chen S. Dynamic changes in the expression of growth factor receptors in the myocardium microvascular endothelium after murine myocardial infarction. Chinese Med J 2007; 120 (6):485-490.

91. Laham RJ, Simons M, Sellke F. Gene transfer for angiogenesis in coronary artery disease. Ann Rev Med. 2001;52:485-502.

92. Herttuala SY, Alitalo K. Gene transfer as a tool to induce therapeutic vascular growth. Nat Med 2003; 9:694-700.

93. Tse HF, Kwong YL, Chan JK, Lo G, Ho CL, Lau CP. Angiogenesis in ischaemic myocardium by intramyocardial autologous bone marrow mononuclear cell implantation. Lancet 2003; 361(9351):47-9.

94. Schuster MD, Kocher AA, Seki T, Martens TP, Xiang G, Homma S, Itescu S. Myocardial neovascularization by bone marrow angioblast results in cardiomyocytes regeneration. Am J Physiol Heart Circ Physiol 2004; 287:525532.

95. Sbaa E, DeWever J, Martinive P, Bouzin C, Frérart F, Balligand J, Dessy C, Feron O. Caveolin plays a central role in endothelial progenitor cell mobilization and homing in SDF-1 - driven postischemic vasculogenesis. Circ Res 2006; 98:1219-1227. 
96. Uemura R, Xu M, Ahmad N, Ashraf M. Bone marrow stem cells prevent left ventricular remodeling of ischemic heart through paracrine signaling. Circ Res 2006; 98:1414-1421.

97. Zuk PA, Zhu M, Ashjian P, De Ugarte DA, e cols. Human adipose tissue is a source of multipotent stem cells. The Am Society for cell Biol. 2002; 13:42794295 .

98. Hydén M, Dicker A, Götherström C, Aström G, Tammik C, Arner P, le Blanc K. Functional, characterization of human mesenchymal stem cell-derived adipocytes. Bioch and Biophy Res Commu 2003; 311:391-397.

99. Lee RH, Kim B, Choi I, Kim H, Choi HS, Suh KT, Bae YC, Jung JS. Characterization and expression analysis of mesenchymal stem cells from human bone marrow and adipose tissue. Cell Physiol Bioch 2004; 14:311-324.

100. Strem BM, Hicok KC, Zhu M, Wulur I, Alfonso Z, Schreiber RE, Fraser JK, Hedrick MH. Multipotential differentiation of adipose tissue -derived stem cells. J Med. 2005; 54: 132-141.

101. Rehman J, Traktuev D, Li J, Merfeld-Clauss S, Temm-Grove CJ, Bovenkerk JE, Pell CL, Johnstone BH, Considine RV, March KL. Secretion of angiogenic and antiapoptotic factors by human adipose stromal cells. Circulation. 2004 16;109(10):1292-8.

102. Kilroy GE, Foster SJ, Wu X, Ruiz J, Sherwood S, Heifetz A, Ludlow JW, Stricker DM, Potiny S, Green P, Halvorsen YD, Cheatham B, Storms RW, Gimble JM. Cytokine profile of human adipose-derived stem cells: Expression of angiogenic, hematopoietic, and pro-inflammatory factors. J Cell Physiol. 2007;212(3):702-9. 
103. Gimble J, Katz AJ, Bunnell BA. Adipose-derived stem cells for regenerative medicine. Circ Res 2007; (100):1249-1260.

104. Planat-Benard V, Silvestre J-S, Cousin B, André M, e cols. Plasticity of human adipose lineage cells toward endothelial cells. Circulation. 2004;109:656663.

105. Fraser J. Schreiber B, Strem B, Zhu M, Alfonso Z. Wulur I. Plasticity of human adipose stem cells toward endothelial cells and cardiomyocytes. Nature 2006; (3)33-37.

106. Miyahara Y, Nagaya N, Kataoka M, Yanagawa B, Tanaka K, Hao H, Ishino K, Ishida H, Shimizu T, Kangawa K, Sano S, Okano T, Kitamura S, Mori H. Monolayered mesenchymal stem cells repair scarred myocardium after myocardial infarction. Nature Med 2006; 12 (4): 459-465.

107. Oswald J, Boxberger S, Jorgensen B, Feldmann S, Ehninger G, Bornhauser M, Werner C. Mesenchymal stem cells can be differentiated into endothelial cells in vitro. Stem Cells. 2004;22(3):377-84.

108. Wosnitza M, Hemmrich K, Groger A, Graber S, Pallua N. Plasticity of human adipose stem cells to perform adipogenic and endothelial differentiation. Differentiation. 2007; 75(1):12-23.

109. Cunningham KS and Gotlieb AI. The role of shear stress in the pathogenesis of atherosclerosis. Lab Invest. 2005; 85:9-23.

110. Yamamoto K, Sokabe T, Watabe T, Miyazono K, Yamashita JK, Obi S, Ohura N, Matsushita N, Kamiya A, Ando J. Fluid shear stress induces 
differentiation of Flk-1-positive embryonic stem cells into vascular endothelial cells in vitro. Am J Physiol 2004; 288:H1915-H1924.

111. Yamamoto K, Takahashi T, Asahara T, Ohura N, Sokabe T, Kamiya A, Ando J. Proliferation, differentiation, and tube formation by endothelial progenitors cells in response to shear stress. J Appl Physiol 2003; 95:2081-2088.

112. Wang H, Riha GM, Yan S, Li M, Chai H, Yang H, Yao Q, Chen C. Shear stress induces endothelial differentiation from a murine embryonic mesenchymal progenitor cell line. Arteriosclerosis, Thrombosis and Vascular Biology 2005; 25:1817-1823.

113. Wang H, Yan S, Chai H, Riha GM, Li M, Yao Q, Chen C. Shear stress induces endothelial transdifferentiation from mouse smooth muscle cells. Biochem and Biophys Res Comm 2006; 346:860-865.

114. O'Cearbhaill ED, Punchard MA, Murphy M, Barry FP, McMugh PE, Barron V. Response of mesenchymal stem cells to the biomechanical environment of the endothelium on a flexible tubular silicone substrate. Biometerials 2007: 1-10.

115. Dimmeler S, Assmus B, Hermann C, Haendeler J, Zeiher AM. Fluid shear stress stimulates phosphorylation of Akt in human endothelial cells. Circ Research 1998; 83:334-341.

116. Ye C, Bai L, Yan Z, Wang Y, Jiang Z. Shear stress and vascular smooth muscle cells promote endothelial differentiation of endothelial progenitor cells via activation of Akt. Clinical Biomechanics 2007. 
117. Huang NF, Yu J, Sievers R, Li S, Lee R. injectable biopolymers enhances angiogenesis after myocardial infarction. Tissue Eng 2005; 11(11/12): 18601866.

118. Kutschka I, Chen IY, Kofidis T, Arai T, Degenfeld G, Sheikh AY, Hendry SL, Pearl J, Hoyt G, Sista R, Yang PC, Blau HM, Gambhir SS, Robbins RC. Collagen matrices enhance survival of transplanted cardiomyoblasts and contribute to functional improvement of ischemic rat hearts. Circulation 2006; 114:167-173.

119. Suuronen EJ, Veinot JP, Wong S, Kapila V, Price J, Griffith M, Mesana TG, Ruel M. Tissue-engineered injectable collagen-based matrices for improved cell elivery and vascularization of ischemic tissue using $\mathrm{CD}_{133^{+}}$progenitors expanded from the peripheral blood. Circulation 2006; 114:138-144.

120. Cortes-Morichetti M, Frati G, Schussler O, Huyen JDV, Lauret E, Genovese JA, Carpentier AF, Chachques JC. Association between a cell-seeded collagen matrix and cellular cardiomyoplasty for myocardial support and regeneration. Tissue Engineering 2007; 13 (11):2681-2687.

121. Siekmann AF, Covassin L, Lawson ND. Modulation of VEGF signalling output by the notch pathway. BioEssays 2008; 30:303-313.

122. Lawson ND, Scheer N, Pham VN, Kim C, Chitnis AB, Campos-Ortega JA, Weinstein BM. Notch signaling is required for arterial-venous differentiation during embryonic vascular development. Development 2001; 128:3675-3683.

123. Roca C, Adams RH. Regulation of vascular morphogenesis by notch signaling. Genes and Develop 2007; 21:2511-2524. 
124. Shawber CJ, Funahashi Y, Francisco E, Vorontchikhina M, Kitamura Y, Stowell A, Borisenko V, Feirt N, Podgrabinska S, Shiraishi K, Chawengsaksophak K, Rossant J, Accili D, Skobe M, kitajewski J. Notch alters VEGF responsiveness in human and murine endothelial cells by direct regulation of VEGFR-3 expression. The J Clin Invest 2007; 117:3369-3382. 
ANEXO II

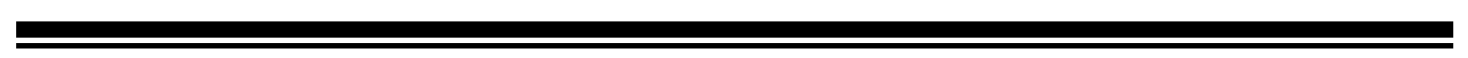


Biodistribution of ${ }^{99} \mathrm{~m}$ Tc-labeled Bone Marrow Cells Administered by Different Routes and Improvement of Cardiac Cell Retention Post-Myocardial Infarction

Juliana S. Nakamuta ${ }^{a}$, Maria E. Danoviz ${ }^{a}$,Fabio L. N. Marques ${ }^{b}$, Claudia Becker ${ }^{a}$, Giovana A. Gonçalves ${ }^{a}$, Paula F. Vassallo ${ }^{a}$, Isolmar T. Schettert ${ }^{a}$, Jose E. Krieger ${ }^{a}$.

${ }^{a}$ Heart Institute (InCor), University of São Paulo Medical School, Av. Dr. Enéas C. Aguiar 44, 05403-000 São Paulo, SP, Brazil.

${ }^{\mathrm{b}}$ Radiopharmacy Laboratory, Nuclear Medicine Center, University of São Paulo Medical School, Rua Dr. Ovídio Pires de Campos s/n, 05403-010 São Paulo, SP, Brazil.

Abbreviated title: Cardiac retention of transplanted cells

Corresponding author: José E. Krieger, M.D., Ph.D., Lab. of Genetics and Molecular Cardiology/LIM 13, Heart Institute (InCor), University of São Paulo Medical School, Av. Dr. Enéas C. Aguiar 44, 05403-000 São Paulo, SP, Brazil.

Telephone: 55113069 5237; fax: 55113082 2354; e-mail: krieger@incor.usp.br http://www.incor.usp.br/genetica

Key words: ${ }^{99 \mathrm{~m}} \mathrm{Tc}$-labeled bone marrow cells, cell therapy, myocardial infarction, timing for therapy, delivery route, fibrin scaffold.

Total word count: 4866 


\section{ABSTRACT}

Cell therapy represents a promising approach for biologic cardiac repair, but key aspects of this strategy remain unclear. We examined the effects of timing and route of administration of bone marrow cells (BMCs) post-myocardial infarction (MI) and the efficacy of a biopolymer to improve cell retention.

${ }^{99 \mathrm{~m}}$ Tc-labeled BMCs $\left(6 \times 10^{6}\right.$ cells $)$ were injected by 4 different routes in adult rats: intravenous (IV), left ventricular cavity (LV), left ventricular cavity with temporal aorta occlusion $\left(\mathrm{LV}^{+}\right)$to mimic coronary injection, and intramyocardial (IM). The injections were performed 24,48 or 72 hours after infarction. Cell retention was estimated by $\gamma$ emission counting of the organs excised $24 \mathrm{hs}$ after cell injection.

Under the experimental conditions, post MI cell retention was not influenced by timing of delivery for any of the 4 routes $(P>0.05)$. Overall cell retention was low, but IM injection was the most efficient $(6.78 \pm 1.34 \%$ of the total radioactivity injected) compared to the IV $(0.17 \pm 0.03 \%, P<0.001), \mathrm{LV}(0.55 \pm 0.10 \%, P<0.001)$, and $\mathrm{LV}^{+}$ $(0.85 \pm 0.17 \%, P<0.01)$ injections. Use of a fibrin biopolymer as vehicle during IM injection lead to 2.5-fold increase in cardiac cell accumulation (17.12 \pm 2.61 vs. $6.84 \pm 1.17 \%, P<0.001)$.

Collectively, the results provide no evidence for the effect of time on cardiac cell retention for cells delivered $24-72 \mathrm{hs}$ post MI. The IM delivery route was the most efficient and the use of a fibrin polymer as vehicle significantly improved cardiac cell retention. Thus, the biomedical potential of this strategy to improve cardiac function and survival deserves to be further investigated. 


\section{INTRODUCTION}

Transplantation of stem and progenitor cells is emerging as a promising therapeutic option for repair of ischemic and infarcted myocardium [1-3]. Nevertheless, the implementation of this novel approach in a clinical setting requires the understanding of a number of key aspects that remain poorly understood. Among the main issues, the optimal timing for therapy and the most appropriate cell delivery route might be of particular importance in order to maximize cell transplantation efficiency.

Previous studies investigating the mobilization of endogenous stem cells and the expression kinetics of cytokines, chemokines, and growth factors have suggested that stem cells may be recruited by the injured myocardium only within a limited time window after infarction [4-6]. This certainly instigates the investigation towards the identification of the ideal timing for cell transplantation. In addition, recent evidence suggests that the combination of cells with biopolymers such as fibrin, collagen and matrigel can improve cell survival, angiogenesis and cardiac function [7-9].

On the other hand, several different routes of cell administration have been proposed to deliver cells including transepicardic [10-14], systemic [15-17] and intracoronary balloon catheter-mediated cell delivery [18-21], however, comparative studies designed to evaluate both their efficiencies and the effect of timing are scarce. The combined evaluation of these parameters is important since the optimal timing for therapy may vary depending on the route used to administer the cells. Indeed, it may be expected that, factors associated to cell in situ retention at the damaged cardiac tissue are essential for the IM injection, whereas cell recruitment should be equally important for 
intravenous injection. Consequently, the optimal time to transplant the cells should be assessed within the context of the delivery modality in order to optimize the efficiency of the predominant underlying mechanism(s) related to each route.

As such, we examined the effect of timing and route of administration of ${ }^{99 \mathrm{~m}} \mathrm{Tc}-$ labeled bone marrow cells (BMCs) on cardiac cell retention, as well as the efficacy of a biopolymer used as vehicle to improve retention in rats submitted to experimental myocardium infarction (MI).

\section{MATERIALS AND METHODS}

\section{Animal Ischemia Model}

The experimental procedures followed the institutional guidelines for care and use of laboratory animals and were approved by the Institutional Review Board of the University of São Paulo Medical School, Brazil (\#527/04). Ten-week-old male inbred Lewis rats were kept on a rat chow diet and water ad libitum and housed under an alternating 12-h light-dark cycle. A lateral thoracotomy was performed under anesthesia with ketamine (50 mg/kg body wt; Parke-Davis, Ann Arbor, MI, USA) and xylazine (10 $\mathrm{mg} / \mathrm{kg}$, i.p.; Bayer, Newhaven, CT, USA) while the animals were ventilated at $2.5 \mathrm{~mL}$, 65 strokes/min with a pressure cycled rodent ventilator (HARVARD Apparatus, Model 683, Holliston, MA, USA). The heart was exposed and the left coronary artery was looped by a single nylon suture (5.0) at approximately $1 \mathrm{~mm}$ from its origin, gently tied for $45 \mathrm{~min}$ and then released. This procedure produced a clearly demarcated (cyanotic and bulging) area of acute ischemia corresponding to the distribution of the left coronary 
artery distal to the occlusion. The chest was closed and rats were individually caged during a 24-hour period for recovery.

\section{Cell isolation and radiolabeling}

Under sterile conditions, the femur and tibia of ten-week-old male Lewis rats were excised, and connective tissue was removed. Bone marrow (BM) plugs were extracted from the bones by flushing their cavities with Dulbecco's modified Eagle's medium (DMEM). The resulting BM suspension was carefully minced by passing it through subsequent pipettes of decreasing sizes. The red blood cells were removed by density-gradient centrifugation at $829 g$ for 30 minutes after adding an equal volume of Ficoll-Paque $^{\mathrm{TM}}$ Plus (Amersham Bio Sciences AB, Uppsala, Sweden) solution to the BM suspension. Following centrifugation, the low density fraction, composed of the socalled fresh unfractioned bone marrow cells (BMCs), was collected and rinsed with phosphate-buffered saline (PBS).

Ceretec $®$ lyophilized kit (Amersham) was reconstituted in $2 \mathrm{~mL}$ of $0.9 \% \mathrm{NaCl}$ solution containing $1.48 \mathrm{GBq}(40 \mathrm{mCi})$ of sodium pertecnetate (IPEN-CNEN, Brazil). Radiochemical purity of the labeled product [technetium 99m-hexamethylpropylene amine oxime $\left.\left({ }^{99 \mathrm{~m}} \mathrm{Tc}-\mathrm{HMPAO}\right)\right]$ was determined by ethyl acetate/saline extraction procedure. BMCs were labeled with ${ }^{99 \mathrm{~m}} \mathrm{Tc}-\mathrm{HMPAO}$, with a minimum change in standard labeling procedures for leucocytes [22]. Briefly, the suspension of BMCs was centrifuged, supernatant was removed and the pellet was resuspended in $1 \mathrm{~mL}$ of ${ }^{99 \mathrm{~m}} \mathrm{Tc}$ HMPAO solution and incubated for $15 \mathrm{~min}$ at $37^{\circ} \mathrm{C}$. Plasma was then added to interrupt cell tagging and the suspension was centrifuged at $466 g$ for 10 minutes. The supernatant 
was discarded and the pellet resuspended in PBS. The centrifugation and suspension procedure was repeated. The labeling efficiency was assessed and calculated as the ratio of the activity in ${ }^{99 \mathrm{~m}} \mathrm{Tc}-\mathrm{BMCs}$ to the total radioactivity (radioactivity in cells plus in discarded supernatant).

To evaluate BMC labeling stability, a suspension of $6 \times 10^{6}$ cells was incubated for 24 hours and then centrifuged. Radioactivity was measured in the pellet and in the supernatant and the rate of leakage was calculated as labeling efficiency. In order to examine the potentially harmful effects of radiation or chemical components of ${ }^{99 \mathrm{~m}} \mathrm{Tc}$ HMPAO, BMCs viability was determined by the trypan blue dye exclusion test.

\section{Cell Delivery Methods}

Twenty four, 48 or 72 hours after the myocardial ischemia, the animals were subjected to another surgical procedure for a single injection of BMCs $\left(6 \times 10^{6}\right.$ cells $/ 100$ $\mu \mathrm{L}$ of serum-free DMEM) by one of the following experimental routes: intravenous route (IV), injection of the cell suspension into the tail vein; left ventricular cavity route (LV), transepicardial injection directly into the cavity of the left ventricle; left ventricular cavity/intracoronary route $\left(\mathrm{LV}^{+}\right)$, transepicardial injection into left ventricular cavity with aorta occlusion for 20 seconds in order to mimic an intracoronary infusion; and intramyocardial route (IM), transepicardial injection within the infarct border zone of the anterior left ventricular free wall. Organs were harvested for analysis twenty four hours after cell transplantation. 


\section{Nuclear radiometry of harvested organs}

The animals were euthanized and the heart, lungs, liver, spleen, kidneys, femur and a sample of blood (approximately $3 \mathrm{~mL}$ ) were harvested and weighed. The radioactivity of the whole isolated organs was determined in a gamma counter (Automatic Gamma Counter 1480 - Perkin Elmer). The radioactivity values of blood and bones were estimated from the amount of radioactivity in samples of these tissues, considering them as $7 \%$ and $10 \%$, respectively, of the mass of the entire animal [23]. The results were expressed as a percentage of total injected radioactivity after correction for radioactive decay.

\section{Heart uptake of ${ }^{99 \mathrm{~m}} \mathrm{Tc}$ metabolites}

In order to evaluate heart retention and uptake of ${ }^{99 \mathrm{~m}} \mathrm{Tc}$ metabolites leaked from BMCs, $30 \times 10^{6}$ cells were incubated in $500 \mu \mathrm{L}$ of culture medium for 24 hours. The cell suspension was then centrifuged and $100 \mu \mathrm{L}$ of the supernatant were injected in the myocardium of 5 animals, 24 hours after infarction. After another 24 hours, animals were euthanized and the hearts harvested for nuclear radiometry.

\section{Fibrin polymer}

The fibrin polymer was prepared by combining fibrinogen and thrombin at the time of injection. Fibrinogen was obtained by separating the plasma from $50 \mathrm{~mL}$ of rat whole blood and then adding $5 \mathrm{~mL}$ of $3.8 \%$ sodium citrate. Finally, the fibrinogen was isolated using the cryoprecipitation technique [24] and diluted to a final concentration of 
$316 \mathrm{mg} / \mathrm{dL}$. Human thrombin (Baxter Healthcare, Inc.) was used to catalyze fibrin polymerization.

Cells were resuspended in $80 \mu \mathrm{l}$ of the fibrinogen solution and, a few seconds before injection in the tissue, $20 \mu \mathrm{l}$ of thrombin $(250 \mathrm{UI} / \mathrm{ml})$ were added to the syringe containing the cell suspension. This combination allowed a suitable time window of 20 seconds to perform the myocardial injection before polymerization.

\section{Statistical Analysis}

Differences in organ radioactivity among groups were compared by nonparametric Kruskal-Wallis test for 3 or more groups and Mann-Whitney test to compare 2 groups. The Dunn Post-Test was performed when the $P$ value was lower than 0.05 with a compliance interval of $95 \%$. Results are expressed as means \pm standard errors of the mean (SEM).

\section{RESULTS}

\section{Labeling efficiency and stability}

BMCs showed an average labeling efficiency of $14.9 \pm 3.5 \%$, which means that approximately $15 \%$ of the total radioactivity labeled uniformly the cell pool, resulting in 1.98 MBq per $10^{6}$ BMCs. Moreover, the ${ }^{99 \mathrm{~m}} \mathrm{Tc}$ radioactivity detected in BMCs and in the supernatant revealed that only $33.0 \pm 2.5 \%$ of the radioactivity initially incorporated remained within the cells 24 hours after labeling. The absence of significant deterioration of cell viability ( $80 \%$ for labeled vs. $87.5 \%$ for unlabeled BMCs, $P>0.05$ ), 
as indicated by the Trypan blue dye exclusion test, suggested that the radioactivity detected in the supernatant was a consequence of ${ }^{99 \mathrm{~m}} \mathrm{Tc}$ leakage from labeled BMCs rather than cell death. Therefore, in order to determine transplanted cell accumulation, heart radioactivity values were corrected according to the rate of ${ }^{99 \mathrm{~m}} \mathrm{Tc}$ leakage from BMCs in vitro (33.0\%) assuming an equivalent rate of leakage in vivo.

\section{Cardiac cell accumulation, according to timing of therapy}

In order to determine the most appropriate moment to administer cells post-MI, the radiolabeled BMCs were delivered through 4 different routes at 24, 48 and 72 hours post-infarction. Cardiac retention of BMCs did not differ among the timing groups for any of the routes of administration tested (table 1).

Table 1

\section{Cardiac cell accumulation, according to routes of administration}

Since the difference among timing groups was not statistically significant, the samples from each timing group, corresponding to each cell delivery route, were pooled. Therefore, the total number of animals was 15 for the IV route, 12 for $\mathrm{LV}, 13$ for $\mathrm{LV}^{+}$ and 17 for IM. The IM injection was the most efficient, showing a significantly higher cardiac accumulation of BMCs than the injections performed by the IV, LV and LV+ routes $[6.78 \pm 1.34 \%$ of the radioactivity injected vs. $0.17 \pm 0.03(P<0.001), 0.55 \pm 0.10$ $(P<0.001)$ and $0.85 \pm 0.17 \%(P<0.01)$, respectively] (Figure 1). When just the transfusion 
routes were compared, the $\mathrm{LV}^{+}$route was significantly more efficient than the IV route $(P<0.05)$.

Figure 1

To confirm that the radioactivity retention observed in the IM group reflected BMC accumulation, instead of a combination of BMCs with leaked tracer remaining in the tissue, radiolabeled BMCs were incubated for 24 hours, centrifuged and then the supernatant injected by the IM route. The amount of ${ }^{99 \mathrm{~m}} \mathrm{Tc}$ metabolites retained in the heart was 12.5 times lower than the values observed with the labeled injected cells $\left(0.21 \pm 0.05\right.$ vs. $2.62 \pm 0.39$, respectively) indicating that the contribution of free ${ }^{99 \mathrm{~m}} \mathrm{Tc}$ to total myocardium radioactivity could indeed be disregarded.

Interestingly, 24 hours after administration, the biodistribution pattern of radiolabeled BMCs was similar for all delivery routes (figure 2). Approximately $50 \%$ of the injected radioactivity was found in the main harvested organs. High radioactivity values were detected in liver, spleen and kidneys, with markedly lower values in lungs and bones.

Figure 2 


\section{Biopolymer vehicle as a strategy to improve cardiac cell retention}

Given that, in the best scenario, only $\sim 7 \%$ of the injected radioactivity remained in the myocardium 24 hours after grafting, an autologous fibrin polymer was used as vehicle for BMC injection to test whether the polymer could improve cell retention. Myocardium radioactivity values from rats that received BMCs combined with fibrin polymer by IM route were significantly higher than those from animals that received BMCs in standard vehicle (culture medium) by the same route $(17.12 \pm 2.61$ vs. $6.84 \pm 1.17 \%, P=0.0005$ ) (figure 3 ).

Figure 3

In order to examine the possibility that the increased radioactivity retention observed in the fibrin group was a consequence of the trapping of free tracer in the polymer matrix, $10 \mu \mathrm{L}$ of supernatant containing ${ }^{99 \mathrm{~m}} \mathrm{Tc}$ leaked from BMCs was added to the fibrinogen solution before adding thrombin in vitro. After 24 hours of incubation in $500 \mu \mathrm{L}$ of DMEM and two washes in PBS, only $1.29 \pm 0.07 \%$ of the total radioactivity remained bound to the fibrin polymer indicating that free ${ }^{99 \mathrm{~m}} \mathrm{Tc}$ was washed out from the fibrin polymer matrix.

To further confirm these results we tested different and more homogeneous cell types, rat cardiac fibroblasts expressing $\beta$-galactosidase and adipose stem cells, using both fibrin and standard culture medium as vehicle (online supplement data). Twentyfour hours after injection there was higher cell retention in the fibrin compared to the control group (online supplement figure 1). Furthermore, we provided evidence that 
cells co-injected with fibrin survived and remained in the myocardium for at least 30 days indicating that this strategy can indeed increase cardiac cell retention and survival (online supplement figure 2).

\section{DISCUSSION}

The main finding of the present study was that the IM BMC administration was the most efficient route for cardiac cell retention and it could be significantly improved using a fibrin polymer as a vehicle during IM injection. Our data also showed that regardless of the route of administration, there is no time effect on cell retention for cells delivered 24-72 hs post MI.

The most suitable timing for therapy was individually assessed in previous studies; however, these studies analyzed and compared the efficiency of cell injections performed immediately after infarction (an acute scenario) with those performed several days after infarction (a more chronic scenario) $[25,26]$. Instead, we evaluated cell accumulation at the heart following the injection of cells at 24,48 and 72 hours postinjury; the time window during which important changes at the levels of main chemoattractant factors occur [4-6, 27]. We found no evidence for a significant effect of timing on cardiac cell accumulation from 24 to 72 hours post-injury. Interestingly, these data are consistent with a recent clinical finding where optimal reperfusion therapy associated with intracoronary BMC infusion failed to produce improvement when the BMC infusion occurred within 4 days of reperfusion, whereas small but significant improvement in absolute left ventricle ejection fraction was observed when the cells 
were infused from days 5-7 post-reperfusion [28]. However, the lack of effect in our study should be weighed in light of confounding factors. First, we used freshly-isolated unfractionated bone marrow cells as has been used in a variety of early clinical trials, which represent a particularly heterogeneous pool of several different cell populations. Therefore, it is possible that the specific cell fraction able to respond to homing signals is too small to be reliably detected with the technique employed. Secondly, although several cytokines and growth factors are upregulated and released by the injured heart soon after an acute myocardial infarction, it may take time to establish the specific and complete concert of molecules and gradients necessary for the multi-step homing process to effectively occur. Moreover, since the cells were obtained from healthy donor animals, they may first need to be primed by factors present in the infarcted recipient in order to be able to respond to the homing signals [29]. Thirdly, the factors that govern cell recruitment for the reparative process may also govern the acute inflammatory response, thus the recruited cells may encounter a particularly hostile environment that can jeopardize their survival and engraftment during the first days post injury. Finally, the homing process itself may be inefficient, regardless of the time following injury and any other variable.

Remarkably, the data of the present study provide evidence for limited cardiac accumulation and widespread distribution of transplanted cells, regardless of the delivery route employed. The IM route was the most efficient in terms of cardiac cell retention but still relatively unsatisfactory considering that the cells are transplanted directly into the stroma of the target organ. Several mechanisms of cell loss may influence this outcome, including technical problems associated with the delivery, the 
passive clearance from the site of injection through the vascular and lymph systems, and cell death $[25,30-33]$. These mechanisms may also explain the greatest variability of the results observed in the IM route, a fact previously reported by Hou et al [34]. Further studies are necessary in order to determine whether the differences in cell retention among the delivery strategies can indeed be translated into improved therapeutic benefits. In this context, it will be important to address the effect of the different delivery methods on cell retention and survival over time.

Taken together, the above-mentioned findings prompted us to search for strategies aimed at optimizing retention and survival of transplanted cells. The fibrin polymer is a biodegradable structural matrix important in wound healing, and has been shown to improve transplanted cell survival, to induce angiogenesis, to reduce infarct expansion and to preserve cardiac function after a myocardial infarction [7-9]. However, to date, no study has specifically evaluated the cell retention capacity of this injectable scaffold. Here, we demonstrated that the fibrin polymer increased 2.5 times the amount of transplanted cells remaining at the heart during IM injection. Moreover, similar response was also observed with a more homogeneous cell type, cardiac fibroblasts and adipose-derived stem cells, indicting that this strategy may be used with different cell types.

Special care was taken to correct the radioactivity values in the cardiac tissue according to the rate of ${ }^{99 \mathrm{~m}} \mathrm{Tc}$ leakage from labeled BMCs. We validated the correction and showed that the leaked ${ }^{99 \mathrm{~m}} \mathrm{Tc}$ retention was negligible since it was virtually flushed from the heart and, thus, the radioactivity values can likely be attributed to labeled BMCs. Furthermore, the validation experiment was performed by cardiac injection of 
the precise volume of supernatant, where a corresponding number of labeled BMCs were incubated for 24 hours. This is important since chromatographic examinations of the supernatant revealed that the leaked ${ }^{99 \mathrm{~m}} \mathrm{Tc}$ is a mixture of radiochemical species, which is different from that used to label the cells (data not shown). Moreover, it has been previously demonstrated that the IV injection of ${ }^{99 \mathrm{~m}} \mathrm{Tc}-\mathrm{HMPAO}$, which is the complex that labels the cells, does not result in any significant myocardium uptake [35].

It is also important to emphasize: 1. that the measurement of radioactive emissions from the entire organ is far more reliable than direct cell enumeration by histological analyses of a limited number of heart sections; and 2. that we performed direct radioactive tissue counts and not indirect imaging assessment so the effect of analyzing the samples $24 \mathrm{~h}$ later (approximately 4 isotopic ${ }^{99 \mathrm{~m}} \mathrm{Tc}$ half-lives), does not limit our measurements. Consequently, we believe that the use of radioactivity instead of direct enumeration techniques represents an improvement on the estimation of cardiac cell retention delivered by different routes.

Altogether, we provide no evidence for time effect on cardiac cell retention for cells delivered $24-72$ hours post-myocardial infarction. The IM injection was the most efficient route and it could be further improved when a fibrin polymer is used as a vehicle during the cardiac injection. Thus the biomedical potential of this strategy to improve cardiac function and survival deserves to be further investigated. 


\section{Acknowledgements}

We thank Tiago V. Pereira for the assistance in statistical data analyses. We also thank

Miriam R. Y. Okamoto for technical assistance with cell labeling and radiometry determination. This study was funded by grants from public Brazilian Agencies Fundacao de Amparo a Pesquisa do Estado de Sao Paulo (FAPESP \# 01/0009-0), Ministerio da Ciencia e Tecnologia/Conselho Nacional de Desenvolvimento Cientifico e Tecnologico/Ministério da Saude/Departamento Ciencia e Tecnologia (MCT/CNPq/MS/DECIT \#552324/20005-1 and 10120104096700). JSN, MED, CB, and GAG were recipients of fellowships from FAPESP (04/06784-4, 05/54695-3, 03/026718 and 03/02672-4, respectively). 


\section{REFERENCES}

[1] Reinlib L, Field L. Cell transplantation as future therapy for cardiovascular disease?: A workshop of the National Heart, Lung, and Blood Institute. Circulation. 2000 May 9; 101(18): E182-7.

[2] Melo LG, Pachori AS, Kong D, Gnecchi M, Wang K, Pratt RE, et al. Molecular and cell-based therapies for protection, rescue, and repair of ischemic myocardium: reasons for cautious optimism. Circulation. 2004 May 25; 109(20): 2386-93.

[3] Collins SD, Baffour R, Waksman R. Cell therapy in myocardial infarction. Cardiovasc Revasc Med. 2007 Jan-Mar; 8(1): 43-51.

[4] Askari AT, Unzek S, Popovic ZB, Goldman CK, Forudi F, Kiedrowski M, et al. Effect of stromal-cell-derived factor 1 on stem-cell homing and tissue regeneration in ischaemic cardiomyopathy. Lancet. 2003 Aug 30; 362(9385): 697-703.

[5] Abbott JD, Huang Y, Liu D, Hickey R, Krause DS, Giordano FJ. Stromal cellderived factor-1alpha plays a critical role in stem cell recruitment to the heart after myocardial infarction but is not sufficient to induce homing in the absence of injury. Circulation. 2004 Nov 23; 110(21): 3300-5.

[6] Roy S, Khanna S, Kuhn DE, Rink C, Williams WT, Zweier JL, et al. Transcriptome analysis of the ischemia-reperfused remodeling myocardium: temporal changes in inflammation and extracellular matrix. Physiol Genomics. 2006 May 16; 25(3): 364-74.

[7] Christman KL, Vardanian AJ, Fang Q, Sievers RE, Fok HH, Lee RJ. Injectable fibrin scaffold improves cell transplant survival, reduces infarct expansion, and induces 
neovasculature formation in ischemic myocardium. J Am Coll Cardiol. 2004 Aug 4; 44(3): 654-60.

[8] Christman KL, Fok HH, Sievers RE, Fang Q, Lee RJ. Fibrin glue alone and skeletal myoblasts in a fibrin scaffold preserve cardiac function after myocardial infarction. Tissue Eng. 2004 Mar-Apr; 10(3-4): 403-9.

[9] Huang NF, Yu J, Sievers R, Li S, Lee RJ. Injectable biopolymers enhance angiogenesis after myocardial infarction. Tissue Eng. 2005 Nov-Dec; 11(11-12): 18606.

[10] de Oliveira SA, Gowdak LH, Buckberg G, Krieger JE. Cell biology, MRI and geometry: insight into a microscopic/macroscopic marriage. Eur J Cardiothorac Surg. 2006 Apr; 29 Suppl 1: S259-65.

[11] Gowdak LH, Schettert IT, Rochitte CE, Rienzo M, Lisboa LA, Dallan LA, et al. Transmyocardial laser revascularization plus cell therapy for refractory angina. Int $\mathbf{J}$ Cardiol. 2007 Jul 30.

[12] Hodgson DM, Behfar A, Zingman LV, Kane GC, Perez-Terzic C, Alekseev AE, et al. Stable benefit of embryonic stem cell therapy in myocardial infarction. Am J Physiol Heart Circ Physiol. 2004 Aug; 287(2): H471-9.

[13] Liu Y, Guo J, Zhang P, Zhang S, Chen P, Ma K, et al. Bone marrow mononuclear cell transplantation into heart elevates the expression of angiogenic factors. Microvasc Res. 2004 Nov; 68(3): 156-60.

[14] Olivares EL, Ribeiro VP, Werneck de Castro JP, Ribeiro KC, Mattos EC, Goldenberg RC, et al. Bone marrow stromal cells improve cardiac performance in 
healed infarcted rat hearts. Am J Physiol Heart Circ Physiol. 2004 Aug; 287(2): H46470.

[15] Chin BB, Nakamoto Y, Bulte JW, Pittenger MF, Wahl R, Kraitchman DL. 111In oxine labelled mesenchymal stem cell SPECT after intravenous administration in myocardial infarction. Nucl Med Commun. 2003 Nov; 24(11): 1149-54.

[16] Aicher A, Brenner W, Zuhayra M, Badorff C, Massoudi S, Assmus B, et al. Assessment of the tissue distribution of transplanted human endothelial progenitor cells by radioactive labeling. Circulation. 2003 Apr 29; 107(16): 2134-9.

[17] Schuster MD, Kocher AA, Seki T, Martens TP, Xiang G, Homma S, et al. Myocardial neovascularization by bone marrow angioblasts results in cardiomyocyte regeneration. Am J Physiol Heart Circ Physiol. 2004 Aug; 287(2): H525-32.

[18] Strauer BE, Brehm M, Zeus T, Kostering M, Hernandez A, Sorg RV, et al. Repair of infarcted myocardium by autologous intracoronary mononuclear bone marrow cell transplantation in humans. Circulation. 2002 Oct 8; 106(15): 1913-8.

[19] Assmus B, Schachinger V, Teupe C, Britten M, Lehmann R, Dobert N, et al. Transplantation of Progenitor Cells and Regeneration Enhancement in Acute Myocardial Infarction (TOPCARE-AMI). Circulation. 2002 Dec 10; 106(24): 3009-17.

[20] Perin EC, Dohmann HF, Borojevic R, Silva SA, Sousa AL, Mesquita CT, et al. Transendocardial, autologous bone marrow cell transplantation for severe, chronic ischemic heart failure. Circulation. 2003 May 13; 107(18): 2294-302.

[21] Tse HF, Kwong YL, Chan JK, Lo G, Ho CL, Lau CP. Angiogenesis in ischaemic myocardium by intramyocardial autologous bone marrow mononuclear cell implantation. Lancet. 2003 Jan 4; 361(9351): 47-9. 
[22] Insert packdge Ceretec ${ }^{\circledR}$ product monograph. Little Chalfont - Buckinghamshire: Amersham plc.

[23] Brown RP, Delp MD, Lindstedt SL, Rhomberg LR, Beliles RP. Physiological parameter values for physiologically based pharmacokinetic models. Toxicol Ind Health. 1997 Jul-Aug; 13(4): 407-84.

[24] Radosevich M, Goubran HI, Burnouf T. Fibrin sealant: scientific rationale, production methods, properties, and current clinical use. Vox Sang. 1997; 72(3): 133-43. [25] Zhang M, Methot D, Poppa V, Fujio Y, Walsh K, Murry CE. Cardiomyocyte grafting for cardiac repair: graft cell death and anti-death strategies. J Mol Cell Cardiol. 2001 May; 33(5): 907-21.

[26] Barbash IM, Chouraqui P, Baron J, Feinberg MS, Etzion S, Tessone A, et al. Systemic delivery of bone marrow-derived mesenchymal stem cells to the infarcted myocardium: feasibility, cell migration, and body distribution. Circulation. 2003 Aug 19; 108(7): 863-8.

[27] Vandervelde S, van Luyn MJ, Tio RA, Harmsen MC. Signaling factors in stem cell-mediated repair of infarcted myocardium. J Mol Cell Cardiol. 2005 Aug; 39(2): $363-76$

[28] Schachinger V, Erbs S, Elsasser A, Haberbosch W, Hambrecht R, Holschermann $\mathrm{H}$, et al. Intracoronary bone marrow-derived progenitor cells in acute myocardial infarction. N Engl J Med. 2006 Sep 21; 355(12): 1210-21.

[29] Lapidot T, Dar A, Kollet O. How do stem cells find their way home? Blood. 2005 Sep 15; 106(6): 1901-10. 
[30] Muller-Ehmsen J, Whittaker P, Kloner RA, Dow JS, Sakoda T, Long TI, et al. Survival and development of neonatal rat cardiomyocytes transplanted into adult myocardium. J Mol Cell Cardiol. 2002 Feb; 34(2): 107-16.

[31] Suzuki K, Murtuza B, Beauchamp JR, Smolenski RT, Varela-Carver A, Fukushima S, et al. Dynamics and mediators of acute graft attrition after myoblast transplantation to the heart. Faseb J. 2004 Jul; 18(10): 1153-5.

[32] Dow J, Simkhovich BZ, Kedes L, Kloner RA. Washout of transplanted cells from the heart: a potential new hurdle for cell transplantation therapy. Cardiovasc Res. 2005 Aug 1; 67(2): 301-7.

[33] Yasuda T, Weisel RD, Kiani C, Mickle DA, Maganti M, Li RK. Quantitative analysis of survival of transplanted smooth muscle cells with real-time polymerase chain reaction. J Thorac Cardiovasc Surg. 2005 Apr; 129(4): 904-11.

[34] Hou D, Youssef EA, Brinton TJ, Zhang P, Rogers P, Price ET, et al. Radiolabeled cell distribution after intramyocardial, intracoronary, and interstitial retrograde coronary venous delivery: implications for current clinical trials. Circulation. 2005 Aug 30; 112(9 Suppl): I150-6.

[35] Neirinckx RD, Canning LR, Piper IM, Nowotnik DP, Pickett RD, Holmes RA, et al. Technetium-99m d,1-HM-PAO: a new radiopharmaceutical for SPECT imaging of regional cerebral blood perfusion. J Nucl Med. 1987 Feb; 28(2): 191-202. 


\section{FIGURE LEGENDS}

Figure 1. Cell delivery route and cardiac cell retention. Radioactivity found in the heart after IV (n=15), LV (n=12), $\mathrm{LV}^{+}(\mathrm{n}=13)$ and IM injection $(\mathrm{n}=17) . I V$, intravenous route; $L V$, left ventricular cavity route; $L V+$, left ventricular cavity route with temporal aorta occlusion; $I M$, intramyocardial route.

Figure 2. Tissue organ distribution of radioactivity according to route of cell injection: IV $(n=15), \operatorname{LV}(n=12), \mathrm{LV}^{+}(\mathrm{n}=13)$ and IM $(\mathrm{n}=17)$. Radioactivity values were not corrected according to rate of leakage of the tracer from cells. $I V$, intravenous route; $L V$, left ventricular cavity route; $L V+$, left ventricular cavity route with temporal aorta occlusion; $I M$, intramyocardial route.

Figure 3. Effect of a biopolymer used as a vehicle on radioactivity retention in the heart. Labeled BMCs were delivered by intramyocardial injection using either standard cell media (DMEM, n=22) or fibrin polymer (Fibrin, $n=15$ ) as vehicle. 
ANEXO III

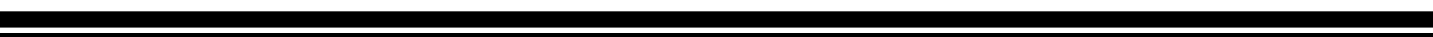




\section{COMPARATIVE STUDY OF ADIPOSE-TISSUE DERIVED STEM CELLS FROM HUMANS AND MICE}

\footnotetext{
${ }^{1}$ Heart Institute (InCor), University of São Paulo Medical School, São Paulo, Brazil.

${ }^{2}$ Immunology Laboratory, University of São Paulo Medical School, São Paulo, Brazil.
}

Running head: Comparative study of ASCs

Correspondence and request for reprints to: José E. Krieger, M.D., Ph.D., Lab. of Genetics and Molecular Cardiology/LIM 13, Heart Institute (InCor), University of São Paulo Medical School, Av. Dr. Enéas C. Aguiar 44, 05403-000 São Paulo, SP, Brazil. Telephone: 55113069 5237; fax: 55113082 2354; e-mail: krieger@incor.usp.br http://www.incor.usp.br/genetica

Total word count: 4610

Key words: Characterization, multilineage potential, CPD, senescence, nuclear morphology, DNA content. 


\section{ABSTRACT}

Background: Stem cells are at the center of attention for several promising applications, however, key aspects regarding the basics of their biology remain unclear. Among the most promising adult stem cells, adipose tissue-derived stem cells (ASCs) are one of the most attractive for therapeutic applications. Here, we studied and compared basic biological characteristics of ASCs from humans (hASCs) and mice (mASCs) relevant for further applications.

Methods and Results: hASCs and mASCs were compared for immunophenotype, differentiation potential, cell growth characteristics, senescence, nuclear morphology and DNA content. Although both ASCs showed a similar immunophenotype, the percentage of CD73+ cells was markedly lower and CD31+ higher in mASC than in hASC cultures. Interespecific differences were also observed for the profile of population doubling times along passages, which was steady in hASC and showed three distinct phases in mASC. The frequency of nuclear aberrations was noticeably lower in hASC than in mASC. Moreover, mASCs showed changes along passages for the frequency of hypodiploid, G0+G1, G2+M and hyperdiploid cells, while all these frequencies remained constant in hASCs.

Conclusions: Collectively, these results suggest that mASCs are more unstable than hASCs for long-term culture. These findings stress the need for caution when interpreting and generalizing the results obtained from different animal models, and highlight the need for more studies on basic stem cell biology and characterization. 


\section{INTRODUCTION}

Stem cells are undifferentiated cells that have the ability to divide indefinitely in culture and eventually, to give rise to specialized cell types. Their differentiation potential depends on whether they were derived from fetal or adult sources. While embryonic stem cells are totipotent, those obtained from adult sources are multipotent and differentiate essentially into the cell types found in the tissue of origin. Since adult stem cells are free of ethical and political concerns, among other important issues, they are attractive for a broad number of potential applications, mainly those regarding cell therapy and regenerative medicine. Hence, a lot of research worldwide is focused on reprogramming adult stem cells to overcome their restricted differentiation potential and to obtain the so-called induced pluripotent stem cells (iPS cells). However, despite the countless advances in the field of stem cells research and the ongoing use of these cells in many clinical trials, knowledge about their basic biological characteristics remains scarce and frequently conflicting. Since the definitive translation of any stem cell-based approach into a clinical setting relies not only on that knowledge but also on the one acquired from diverse organisms, studies characterizing and comparing the basic biology of stem cells from different animal models are of critical importance. The aim of this study was to compare the characteristics of adipose tissue-derived stem cells (ASCs) from humans and mice. Adipose tissue represents an optimal source of stem cells since it is abundant and easy to sample $[16,18]$. Several studies demonstrated that ASCs are able to differentiate into a variety of cell lineages, including the osteogenic [21,25], adipogenic [16,31], chondrogenic [25,26,27], skeletal muscle [28,29], cardiomyocyte 
[17,30], endothelial [32-34], and hepatic lineages [35]. Moreover, ASCs can overcome their mesenchymal commitment and differentiate into nerve cells [36-38].

For all the aforementioned reasons, ASCs are currently considered among the most promising adult stem cells and thus, their basic characteristics must be properly studied and confirmed in different model systems. 


\section{METHODS}

\section{Chemicals}

Dulbeccos's modified Eagle medium (DMEM) low glucose, Fetal Bovine Serum (FBS), penicillin, streptomycin and magnesium choloride salt were purchased from GIBCO $^{\mathrm{TM}}$ Invitrogen Corporation (Carlsbad, CA). X-Gal (5-bromo-4-cholo-3-indolyl $\beta$ D-Galactoside) was purchased from Invitrogen Corporation (CarlsBad, CA). Potassium Ferrocyanide and Ferricyanide, citric acid, monobasic and dibasic sodium phosphate salts, formaldehyde, ferrocyanide, ferricyanide, glutaraldehyde, indomethacin, isoboutyl methylxanthine, and gelatin were purchased from Sigma (St. Louis, USA). Tissue culture dishes and flasks were from Becton Dickinson (Franklin Lakes, New Jersey) and NUNC (Rochester, NY). Sodium chloride was from Merck Biosciences.

\section{Isolation and ex vivo expansion of $\mathrm{mASC}$ and hASC}

Subcutaneous adipose tissue was obtained with approval and guidelines of The University of Sao Paolo Ethics Committee from patients with ages ranging from 24 to 53 that undergone liposuction procedures and from mices from eight to twelve weeks old. Cells were isolated from adipose tissue as previously described. In brief, harvested tissue was enzymatically dissociated and centrifuged. The pelleted cells were then recovered and plated onto $10-\mathrm{cm}$ (human) or $3.5-\mathrm{cm}$ (mouse) culture plate. Cultures were washed with PBS and then refed with fresh medium to remove contaminating erythrocytes and others unattached cells every 24 hours after plating for three days. Plating and expansion medium consisted of DMEM low glucose with 10\% FBS and 
penicillin/streptomycin antibiotics. Cells were maintained at $37^{\circ} \mathrm{C}$ with $5 \% \mathrm{CO} 2$ in tissue culture dishes or flasks and fed twice per week for further experiments. They were grown to confluence after the initial plating (Passage 0), typically within 5-7 days. Once $80 \%$ confluent, the adherent cells were detached with $0.5 \%$ trypsin-EDTA and then either re-plated at $1,0 \times 10^{4} \mathrm{cels} / \mathrm{cm}^{2}$ or used for experimental analysis. Cultures were passaged every 3-5 days until they were ready for analysis.

\section{Growth Kinetics determination}

For determination of doubling time, $5.0 \times 10^{4}$ cells per well were seeded in 6 well plates and every 24 hours were harvested and fixed in $3.7 \%$ formaldehyde prior to counting under hematocytomer in a blind way. Doubling time was calculated from times for doubling cell number in the log phase of the resulting growth curve.

In order to determine the number of cumulative population doublings, cells were seeded at $1.0 \times 10^{4}$ cell $/ \mathrm{cm}^{2}$ into cell flasks cultures. After $80 \%$ confluence, the cells were trypsinized, counted and reseeded at the same density. The numbers of PDs were calculated using the formula $P D=\log N / \log 2$, where $\mathrm{N}$ is the cell number of the harvested monolayer divided by the initial number of cells seeded. This procedure was repeated in every passage.

\section{Cell senescence determination}

To determine the cell senescence, it was used the cytochemical senescenceassociated $\beta$-galactosidase (SA- $\beta$-Galactosidase) assay (X-gal, $\mathrm{pH}$ 6.00). In brief, cells 
were washed twice with PBS and fixed with $2 \%$ formaldehyde, $0.2 \%$ glutaraldehyde in PBS for 5 min at room temperature. After washed with PBS, cells were incubated with senescence-associated $\beta$-galactosidase staining solution $(1 \mathrm{mg} / \mathrm{ml}$ 5-bromo-4-chloro-3indolyl-b-D-galactopyranoside (X-gal); $40 \mathrm{mM}$ citric acid/sodium phosphate buffer; $5 \mathrm{mM}$ potassium ferrocyanide and ferricyanide; $150 \mathrm{mM} \mathrm{NaCl}$; and $2 \mathrm{mM} \mathrm{MgCl} 2$ ) at pH6.0 and $37^{\circ} \mathrm{C}$ for $24 \mathrm{~h}$. Four random fields were digitally photographed (100X magnification) and the percentage of positive blue-dyed cells was counted by an observer blinded to cell identification.

\section{Differentiation of MSC}

Cell was evaluated for multilineage developmental plasticity using in vitro assays well described in the literature []. Briefly, adipogenic differentiation was induced by incubating cells on passage three with DMEM Low Glucose and 10\% FBS supplemented with $1 \mu \mathrm{M}$ dexamethasone, $500 \mu \mathrm{M}$ isobutyl methylxanthine, $200 \mu \mathrm{M}$ indomethacin and $10 \mu \mathrm{M}$ insulin for 21 days. Osteogenic differentiation was obtained by incubating human cells with DMEM Low Glucose and 10\% FBS supplemented with $0.1 \mu \mathrm{M}$ dexamethasone, $10 \mathrm{mM} \beta$-glycerophosphate, and $50 \mu \mathrm{g} / \mathrm{mL}$ ascorbic acid for 21 weeks. In addition to these protocol, mouse cells was incubated with $2.5 \mu \mathrm{M}$ all-trans retinoic acid, which was already described as critical for enhancing the mouse cells differentiation toward ostoblasts. Differentiation along the adipogenic and osteogenic lineages was assessed qualitatively based on cell morphology and cytochemistry (Oil Red O and von Kossa stain, respectively) as previously described []. 


\section{Flow Cytometry}

For cell surface characterization, flow cytometric analyses were performed. In brief, cells were harvested using $0.25 \%$ trypsin-EDTA and $1 \times 10^{6}$ were incubated with the $1 \mu \mathrm{g}$ conjugated antibodies for 15 minutes at room temperature in the dark. The antibodies that were used was CD13, CD29, CD31, CD14, CD34, CD44, CD45RO, CD49E, CD51/61, CD73, CD90, CD105, CD106, HLA-ABC, FLK-1 and SCA-1 (BD Biosciences, San Jose, CA) and AC133 (Myltenyi Biotec). As negative controls, were used inespecific igG antibodies. After washing with PBS $+2 \%$ FBS and fixating with PBS $+1 \%$ formaldehyde, cells were analyzed on a flow cytometer (FACSCalibur, Becton Dickinson, San Jose, CA, USA) and collected 10,000 events for data analyzing with Cell Quest Software (Becton Dickinson, San Jose, CA, USA).

\section{DNA content and cell cycle analysis}

Cells suspensions were treated following the method described by Nicolleti et al []. Briefly, ethanol-fixed cells were washed in phosphate-buffered saline (PBS) and resuspended in $0.1 \%$ propidium iodide (Sigma, USA) with $0.1 \%$ Triton X-100. The fluorescence of individual nuclei was measured using a FACS scan flow cytometer (program CellQuest, Becton Dickinson, Mountain View, CA, USA).

\section{Statistical Analysis}

All data from multiple donors experiments are expressed as means \pm SEM and is assumed the normality on distribution of frequencies and equal variances between 
groups. Differences between groups means were analyzed using paired Student's $t$ test and ANOVA with Bonferroni test post hoc. $\mathrm{p}$ values $<0.05$ were considered significant.

\section{RESULTS}

\section{Surface immunophenotype}

Flow cytometric analyses were performed on passage 4 hASCs and mASCs in order to discern potential interespecific differences in the expression profile of a characteristic panel of surface markers. As shown in figure 1A, the surface immunophenotype of ASCs derived from human and mouse were similar. Both ASCs showed comparable percentages of CD90+, CD29+ and CD44+ cells. Cells positive for CD73 were also observed in both ASCs, but with a markedly lower frequency in those from mice $(\mathrm{p}<0.014)$. The marker CD31 was observed in less than $2 \%$ of the hASCs while present in more than $15 \%$ of the mASCs $(\mathrm{p}<0.002)$. As expected, both ASCs were essentially negative for CD45 (less than $6 \%$ in both species).

As shown in figure 1B, the combination of markers CD90 and CD29 defined relatively homogeneous populations in both, hASCs and mASCs.

\section{Multilineage potential}

To compare the differentiation potential of hASCs and mASCs toward the adipogenic and osteogenic lineages, cells at passage 3 and 4 were cultured in lineagespecific inductive media. Twenty-one days after adipogenic induction, both ASCs showed accumulation of lipid vesicles as examined by Oil Red staining (figure 2A and 
C), thus confirming the adipogenic differentiation potential of ASCs from different species. The potential for osteogenic differentiation was also verified in both ASCs by means of von Kossa staining (figure 2B and D); although using different differentiation conditions for each ASC. Medium modifications described by Wan et al were necessary in order to induce mASCs to differentiate toward the osteogenic lineage [].

\section{Cell growth characteristics}

Although both ASCs could be maintained in vitro for extended periods, hASCs and mASCs showed markedly different proliferative kinetics. As shown in figure 3A, as soon as 48 hours in culture, the mean number of harvested hASCs and mASCs at passage 2 varied significantly $(\mathrm{p}<0.05)$. Thus, to further examine the self-renewal capabilities of hASC and mASC, population doubling times (PDTs) were determined in consecutive passages up to passage 10. The mean PDT along passages was $98.08 \pm 6.15$ hours for hASC, ranging from 72.11 to 129.23 , and $52.58 \pm 3.74$ hours for mASC, ranging from $X$ to $X$ hours. This fold difference in average PDT between hASC and mASC was statistically significant $(\mathrm{p}<0.05)$.

To examine the long-term growth patterns of ASCs, we analyzed the cumulative population doublings (CPDs) of hASC and mASC with respect to passage number. In hASCs, the average number of CPDs increased until approximately passage 15, reaching an apparent plateau phase thereafter (figure 3B). In contrast, in mASCs the average number of CPDs increased steadily and reached levels significantly higher than those observed for humans. 


\section{Cell senescence}

In order to further characterize the growth kinetics of hASC and mASC, cell senescence levels were evaluated from P1 to P10 using a standard $\beta$-galactosidase staining assay at $\mathrm{pH}$ 6. While low and relatively constant percentages of $\beta$-galactosidase positive cells were found in hASCs cultures as they were passaged, the percentage of positive cells in mASCs tended higher after passage 6 (figure 4 , p not significant). However, despite these increases, the levels of cell senescence in mASCs were always lower than those of hASCs at corresponding passages. Still, the observed interespecific differences were small and not statistically significant.

\section{Nuclear morphology}

The routine observation of ASC cultures under inverted phase-contrast microscope revealed further interespecific differences. Human cells show a regular appearance as they are passaged while murine cells are small and highly condensed at initial passages and become more distended and irregular at later ones. The presence of binuclear cells were noted in both, mASC and hASC cultures. Thus, to characterize and determine the frequency of potential nuclear alterations, fixed cell preparations from P1 to P7 were stained and nuclear morphology categorized as described in methods. Interestingly, ASCs cultures from mice and humans could be readily distinguished based on their overall cellular and nuclear morphology (supl. figure). As shown in table 1, regardless of the passage number, mASCs showed a higher frequency of nuclear alterations than hASC . In both ASCs, the more common alterations were the occurrence of an atypically prominent nucleus and the presence of two nuclei in the same cell. 
Interestingly, in mASC the frequency of large nuclei tended to increase along passages while in hASCs it remained constant and low.

\section{DNA content and cell cycle kinetics}

Since atypically large nuclei could be a consequence of polyploidy, we next investigated the DNA content and cell cycle kinetics of ASC cultures at different passages. As shown in figure 5A, the frequency of hyperdiploid mASCs increased until passage 10 while that of hASC showed a mild tendency to decrease along passages. Moreover, in mASC the frequency of hyperdiploid cells is correlated with the frequency of cells with large nucleus (figure 5B), suggesting that large nuclei may, indeed, have an hyperdiploid DNA content.

Interestingly, the cell cycle distribution of the two ASCs revealed patterns more dissimilar than expected (figure 6). hASCs showed relatively constant percentages of cells in G1/G0 (total mean of $91.94 \pm 0.73 \%), \mathrm{S}(2.01 \pm 0.16 \%)$ and G2/M (total mean of $4.86 \pm 0.43 \%$ ) along passages. In contrast, mASCs showed discernible differences, although marginally not statistically significant, between passage 1 and passage 10 in terms of each, the percentage of cells in G1/G0 $(68.69 \pm 5.48 \%$ for P1 and $14.77 \pm 0.16$ $\%$ for P10), the percentage of cells in S $(4.19 \pm 1.16 \%$ for P1 and $0.52 \pm 0.08 \%$ for P10) and the percentage of cells in G2/M (15.96 $\pm 2.43 \%$ for P1 and $52.33 \pm 13.43 \%$ for P10). This accumulation of mASCs with 4C DNA content may indicate a G2 arrest of diploid cells or, alternatively, an accumulation of tetraploid cells in G1.

Another important difference observed between mASCs and hASCs is that mASCs showed frequencies of hypodiploid cells at least 3-fold higher than that of 
hASCs at corresponding passages (figure 6D). This interespecific difference in hypodiploid cells frequency increased steadily from passage 1 to passage 6 and slightly decreased thereafter. Interestingly, the frequencies of hypodipliod mASCs showed a higher variability than those from hASC. 


\section{DISCUSSION}

Stem cell therapy is among the most interesting and promising strategies for organ regeneration and repair. Cell types from different sources and with diverse lineage potential have been tested in a broad spectrum of tissue damage scenarios and diseases. However, the definitive translation of this kind of approaches into a clinical setting relies on the knowledge acquired from animal models. Among these, the mouse is the most extensively studied species and widely used because of its many advantages, mainly the small size, fast breeding, and short life span. Moreover, because of the availability of a complete genomic sequence and the ease of genetic manipulation, mice allow high throughput studies on pathophysiological processes and the detailed examination of potential therapeutic approaches. However, to translate findings from mice to humans, both in vitro and in vivo model systems must be carefully studied and validated to ensure that they resemble the outcome to be expected in humans. To achieve this, studies describing and comparing different models between them and to humans are not only of critical importance but also mandatory.

Some divergences between rodents and human cell cultures have already been described. Murine bone marrow mesenchymal stem cells (mBMSCs) are far more difficult to isolate and culture than those from rat (rBMSCs) and human (hBMSCs) [12]. Moreover, rBMSCs are more sensitive to plating density and expand more rapidly from single cell-derived colonies than hBMSCs [13]. On the other hand, it was recently found that adipose tissue-derived stem cells (ASCs) from mouse require the addition of 
retinoic acid and bone morphogenetic protein $[14,15]$, while human cells require only the basic cocktail containing the hormone dexamethasone.

Moreover, several characteristics of murine cells seem to be altered along time in culture [16]. Mesenchymal stem cells from different mouse strains can acquire chromosomal abnormalities after few passages [17]. On the contrary, human cells undergo spontaneous transformation only after culture periods of about 4-5 months $[18,19]$. 


\section{Acknowledgements}

We thank Tiago V. Pereira for the assistance in statistical data analyses.

\section{Funding sources}

This study was funded by grants from public Brazilian Agencies Fundacao de Amparo a Pesquisa do Estado de Sao Paulo (FAPESP \# 01/0009-0), Ministerio da Ciencia e Tecnologia/Conselho Nacional de Desenvolvimento Cientifico e Tecnologico/Ministério da Saude/Departamento Ciencia e Tecnologia (MCT/CNPq/MS/DECIT \#552324/200051 and 10120104096700). JSN, MED, VB, and GR were recipients of fellowships from FAPESP (04/06784-4, 05/54695-3, 03/02671-8 and 03/02672-4, respectively).

\section{Disclosures}

The authors have no conflicts of interest to disclose. 
Figure 1

(A)

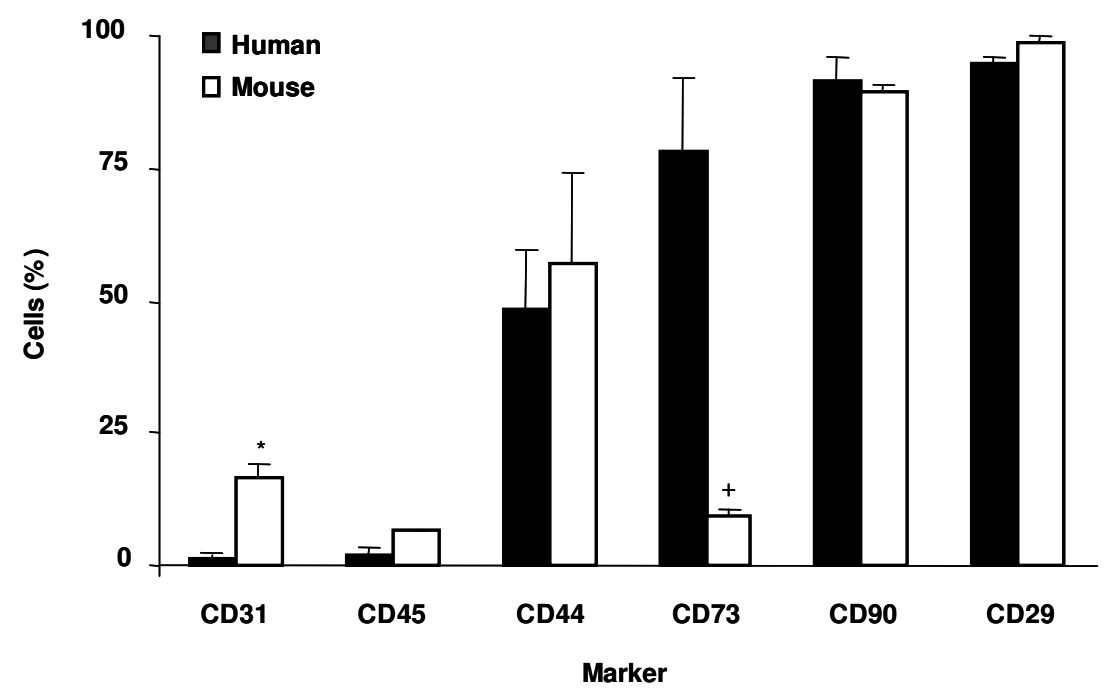

(B)

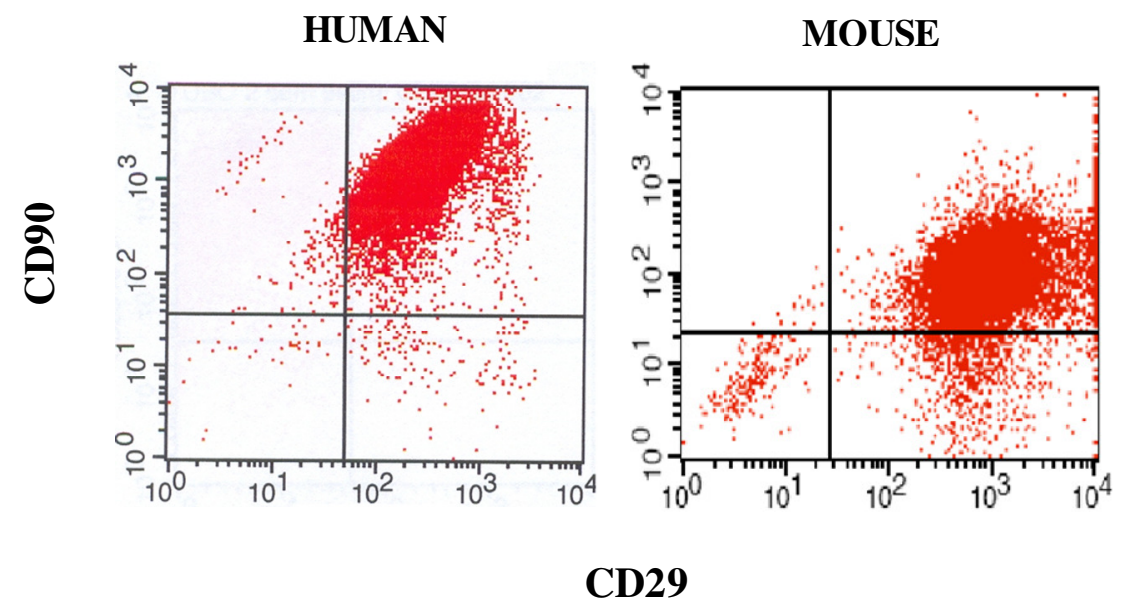


Figure 2

Adipogenesis

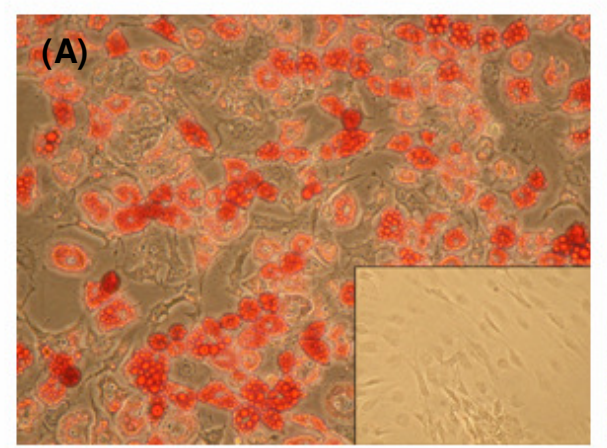

Mouse

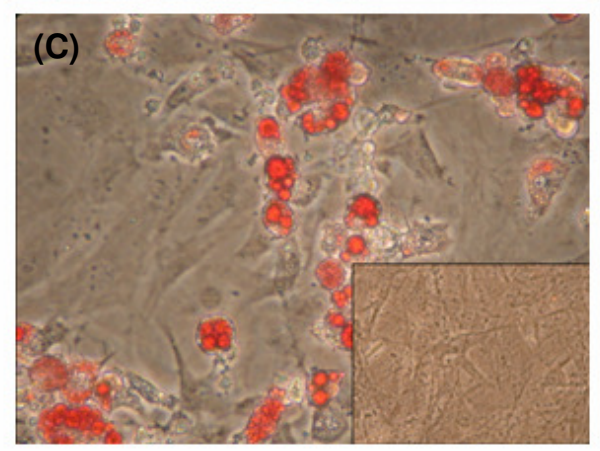

Osteogenesis
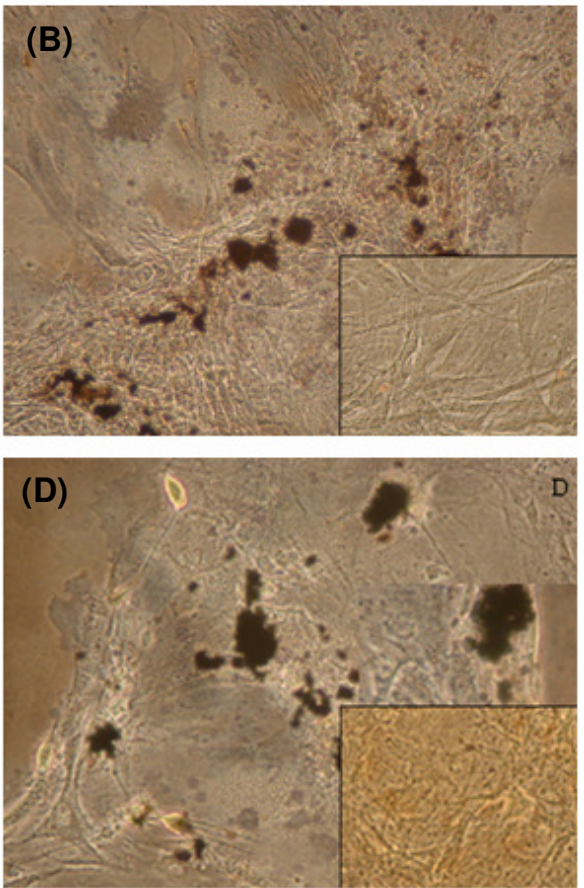
Figure 3

(A)

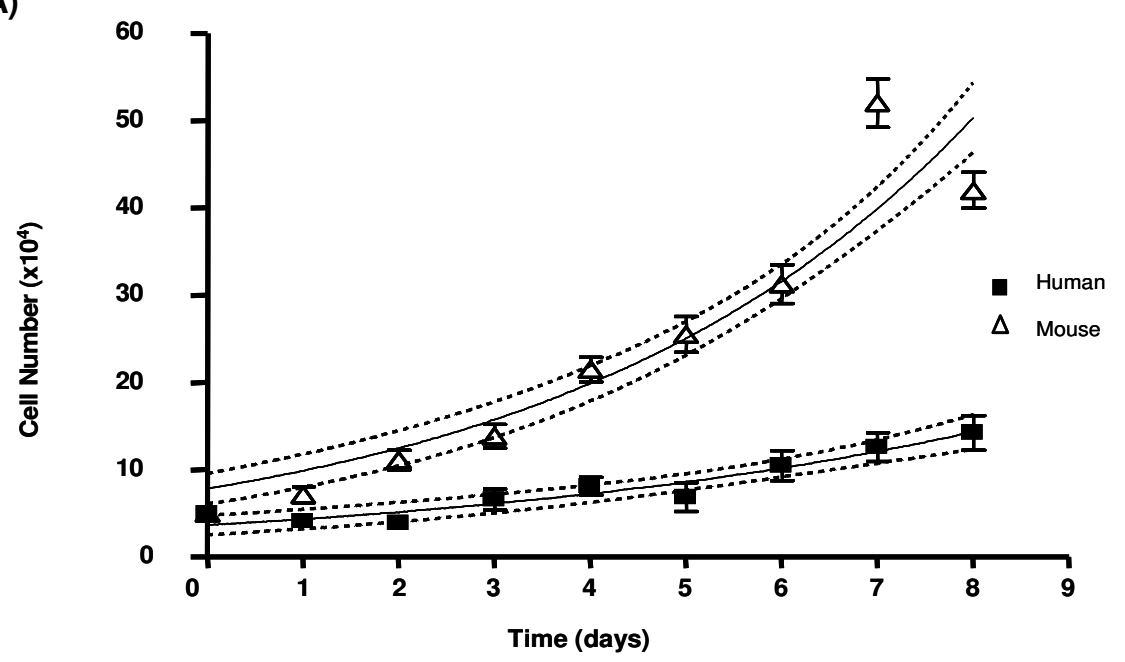

(B)

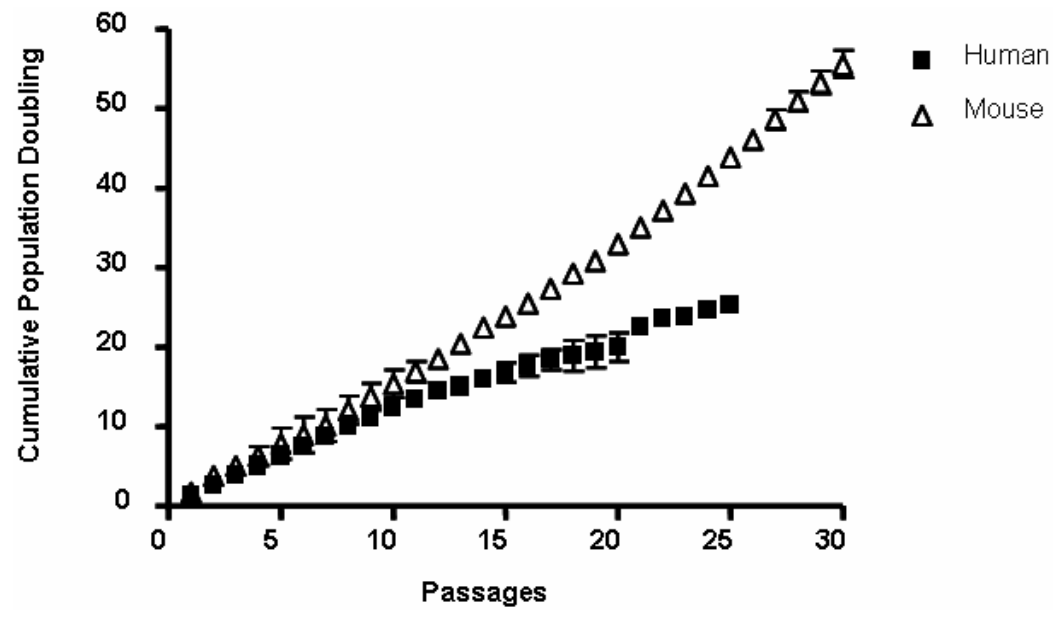


Figure 4

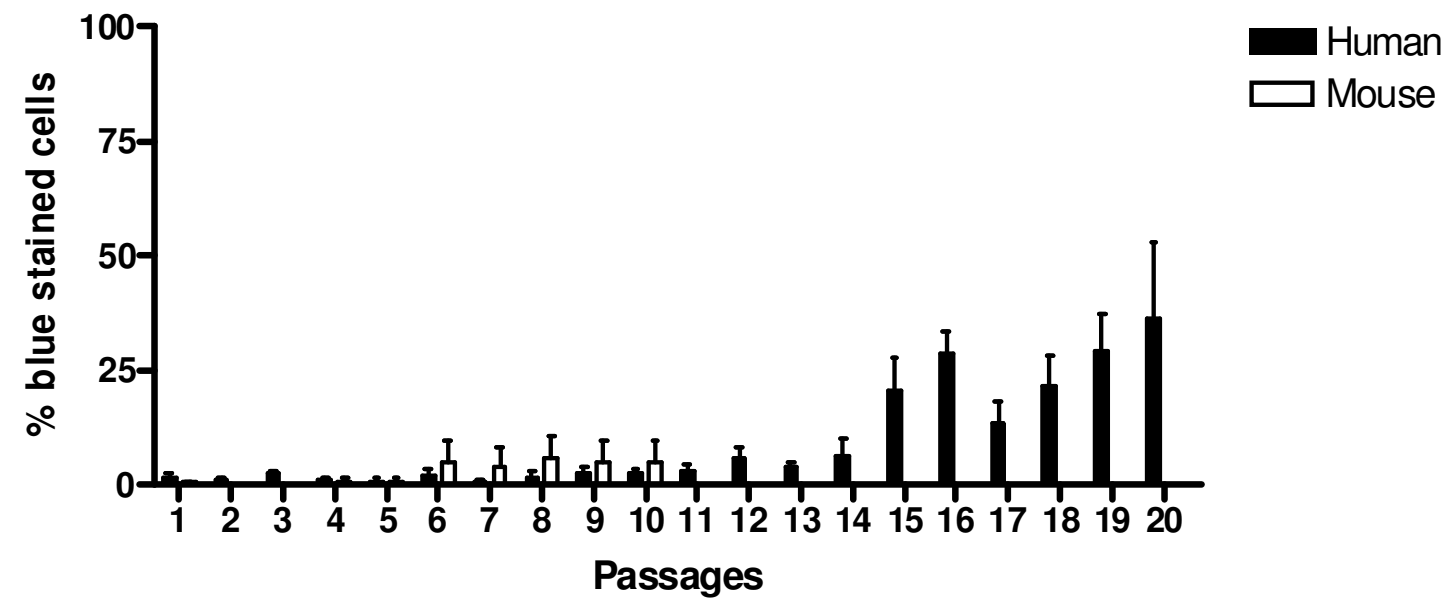


Table 1. Nuclear morphology

\begin{tabular}{|c|c|c|c|c|c|c|c|}
\hline Category & P1 & $\mathbf{P 2}$ & P3 & $\mathbf{P 4}$ & P5 & P6 & P7 \\
\hline \multicolumn{8}{|l|}{ Normal } \\
\hline Human & 95.95 (x.xx) & $96.01(0.86)$ & $96.08(0.98)$ & $96.94(0.73)$ & 95.95 (1.97) & $94.83($ x.xx) & $96.78(0.55)$ \\
\hline Mice & $87.83(2.55)$ & $85.08(2.09)$ & $87.80(5.11)$ & $86.25(6.57)$ & $82.48(2.48)$ & $82.83(2.02)$ & $87.48(0.51)$ \\
\hline \multicolumn{8}{|l|}{ Binucleated } \\
\hline Human & $1.04(\mathrm{x} . \mathrm{xx})$ & $0.83(0.50)$ & $1.19(0.60)$ & $0.94(0.23)$ & $1.44(0.00)$ & $1.68(\mathrm{x} . \mathrm{xx})$ & $1.22(0.38)$ \\
\hline Mice & $3.54(0.52)$ & $6.36(0.70)$ & $2.83(0.05)$ & $2.73(0.15)$ & $4.25(1.94)$ & $3.48(0.43)$ & $2.56(1.17)$ \\
\hline \multicolumn{8}{|l|}{ Trinucleated } \\
\hline Human & $0.00(\mathrm{x} . \mathrm{xx})$ & $0.00(0.00)$ & $0.00(0.00)$ & $0.00(0.00)$ & $0.00(0.00)$ & $0.00(\mathrm{x} . \mathrm{xx})$ & $0.00(0.00)$ \\
\hline Mice & $0.00(0.00)$ & $0.41(0.19)$ & $0.00(0.00)$ & $0.00(0.00)$ & $0.00(0.00)$ & $0.51(0.26)$ & $0.00(0.00)$ \\
\hline \multicolumn{8}{|c|}{ Multinucleated } \\
\hline Human & $0.17(\mathrm{x} . \mathrm{xx})$ & $0.00(0.00)$ & $0.00(0.00)$ & $0.00(0.00)$ & $0.00(0.00)$ & $0.00(\mathrm{x} . \mathrm{xx})$ & $0.00(0.00)$ \\
\hline Mice & $0.00(0.00)$ & $0.00(0.00)$ & $0.00(0.00)$ & $0.00(0.00)$ & $0.00(0.00)$ & $0.26(0.13)$ & $0.00(0.00)$ \\
\hline \multicolumn{8}{|c|}{ With a large nucleus } \\
\hline Human & $1.39(\mathrm{x} . \mathrm{xx})$ & $2.31(0.33)$ & $2.11(0.34)$ & $1.56(0.56)$ & $2.17(1.85)$ & $2.33(\mathrm{x} . \mathrm{xx})$ & $1.61(0.11)$ \\
\hline Mice & $3.30(0.95)$ & $4.17(0.97)$ & $6.02(2.12)$ & $7.76(3.86)$ & $8.92(1.84)$ & $8.57(1.09)$ & $6.28(0.69)$ \\
\hline \multicolumn{8}{|c|}{ With a micronucleus } \\
\hline Human & $0.00(\mathrm{x} . \mathrm{xx})$ & $0.00(0.00)$ & $0.06(0.06)$ & $0.00(0.00)$ & $0.00(0.00)$ & $0.00(\mathrm{x} . \mathrm{xx})$ & $0.00(0.00)$ \\
\hline Mice & $1.08(0.43)$ & $1.08(0.39)$ & $0.95(0.54)$ & $0.21(0.21)$ & $2.04(0.27)$ & $1.83(0.30)$ & $1.24(0.62)$ \\
\hline \multicolumn{8}{|c|}{ With a nuclear bleb } \\
\hline Human & $0.17(\mathrm{x} . \mathrm{xx})$ & $0.00(0.00)$ & $0.00(0.00)$ & $0.00(0.00)$ & $0.00(0.00)$ & $0.00(\mathrm{x} . \mathrm{xx})$ & $0.00(0.00)$ \\
\hline Mice & $1.61(0.75)$ & $0.59(0.59)$ & $0.93(0.93)$ & $0.48(0.48)$ & $0.92(0.92)$ & $0.78(0.24)$ & $0.31(0.31)$ \\
\hline \multicolumn{8}{|c|}{ With an amorphous nucleus } \\
\hline Human & $1.04(\mathrm{x} . \mathrm{xx})$ & $0.47(0.03)$ & $0.14(0.02)$ & $0.32(0.15)$ & $0.22(0.06)$ & $0.13(\mathrm{x} . \mathrm{xx})$ & $0.06(0.06)$ \\
\hline Mice & $0.46(0.18)$ & $0.71(0.44)$ & $0.19(0.19)$ & $0.32(0.32)$ & $0.15(0.15)$ & $0.35(0.35)$ & $0.75(0.29)$ \\
\hline \multicolumn{8}{|c|}{ Not determined } \\
\hline Human & $1.73(\mathrm{x} . \mathrm{xx})$ & $0.38(0.06)$ & $0.42(0.07)$ & $0.24(0.24)$ & $0.22(0.06)$ & $0.91(\mathrm{x} . \mathrm{xx})$ & $0.34(0.00)$ \\
\hline Mice & $2.19(1.12)$ & $1.60(0.56)$ & $1.39(1.39)$ & $2.26(2.26)$ & $1.23(1.23)$ & $1.38(0.61)$ & $1.37(0.96)$ \\
\hline
\end{tabular}

Cells were categorized based on their nucle ar morphology as described in methods. Percentages are presented as mean $( \pm$ SE). 
Figure 5

(A)

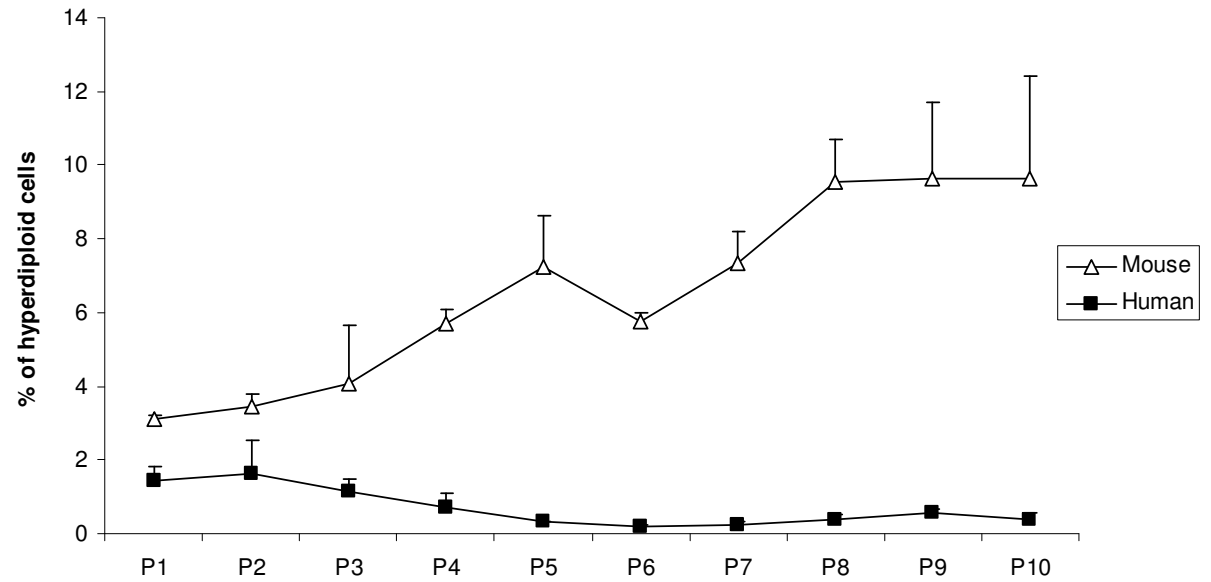

(B)

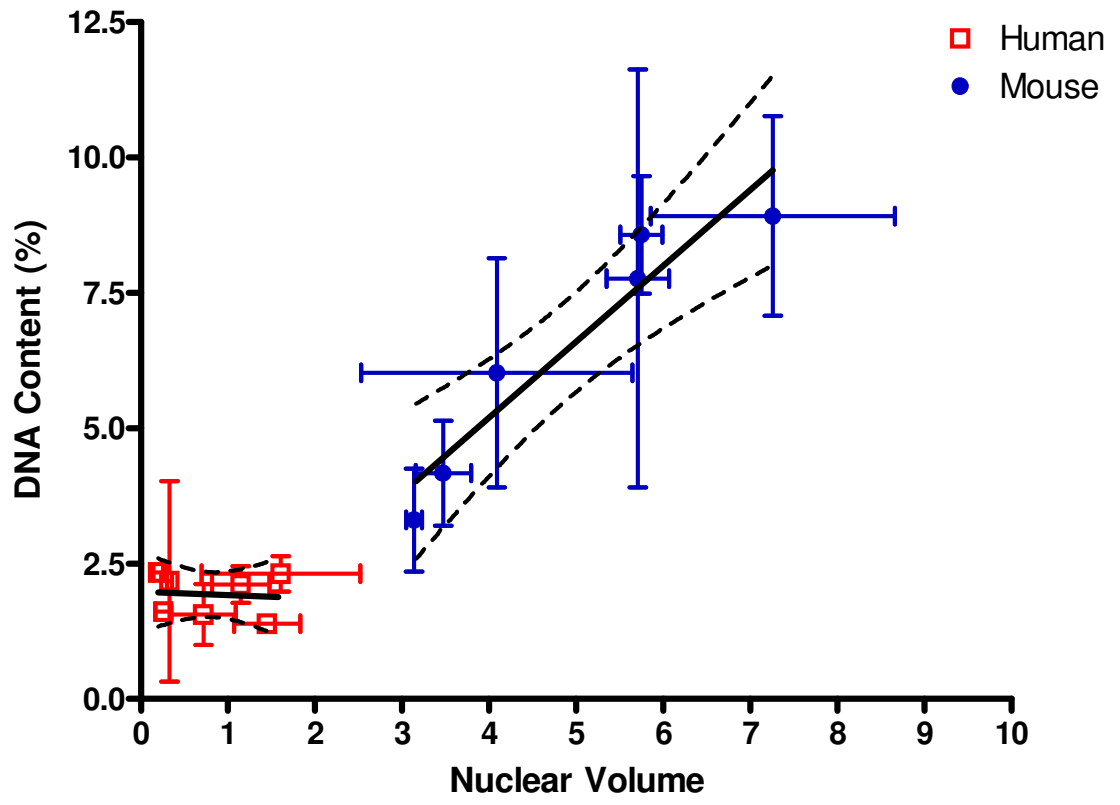


Figure 6

(A)

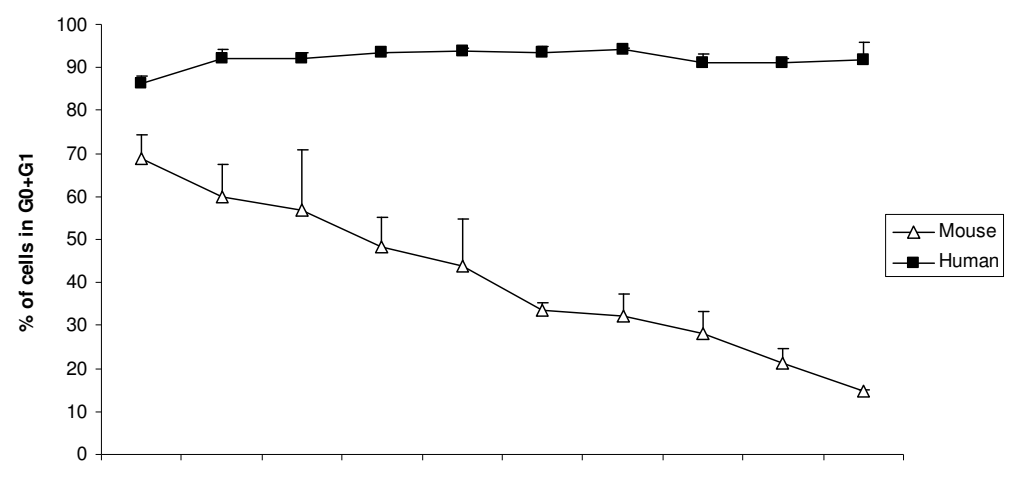

(B)

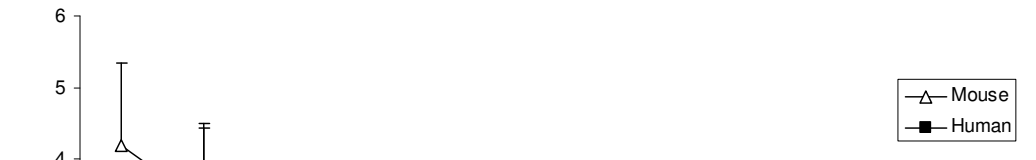

(C)

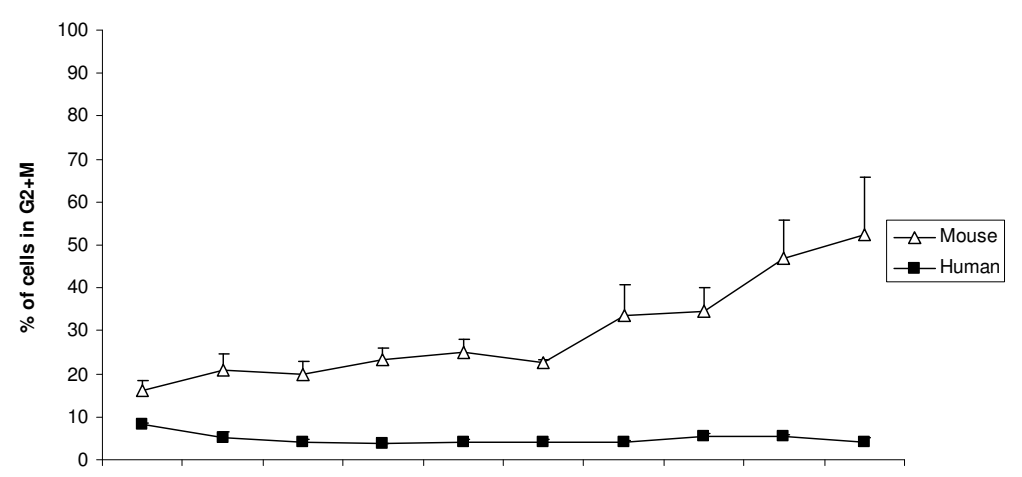

(D)

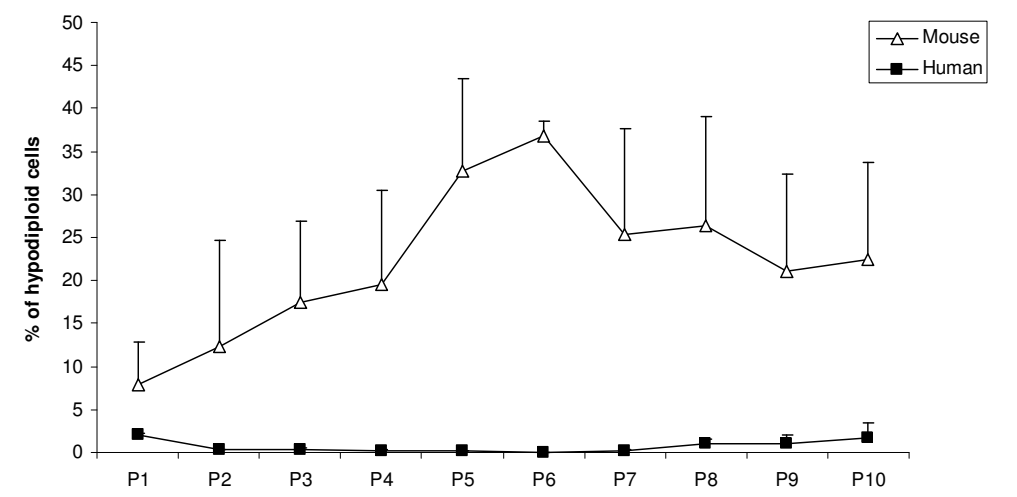




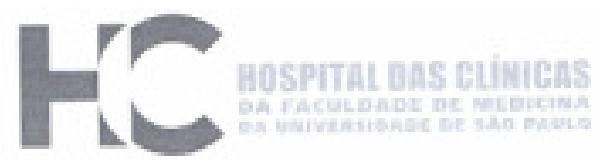

\section{APROVAÇĀO}

A Comissão de Ética para Análise de Projetos de Pesquisa - CAPPesq da Diretoria Clínica do Hospital das Clínicas e da Faculdade de Medicina da Universidade de São Paulo, em sessão de 23/04/2008, APROVOU o Protocolo de Pesquisa $n^{\circ}$ 0118/08, intitulado: "RETENÇÃo CARdíacA dE CÉluLAs dA MEdULA ÓSSEA TRANSPLANTAS: EFEITO DO TEMPO APÓS O INFARTO DO MIOCÁRDIO E DA VIA DE ADMINISTRAÇĀO DAS CÉLULAS" apresentado pela COMISSĀO CIENTÍFICA DO INCOR.

Cabe ao pesquisador elaborar e apresentar à CAPPesq, os relatórios parciais e final sobre a pesquisa (Resoluçăo do Conselho Nacional de Saúde $n^{\circ} 196$, de 10/10/1996, inciso IX.2, letra "c").

Pesquisador (a) Responsável: Prot. Dr. José Eduardo Krieger

Pesquisador (a) Executante: Juliana Sanajotti Nakamuta

CAPPesq, 28 de Abril de 2008
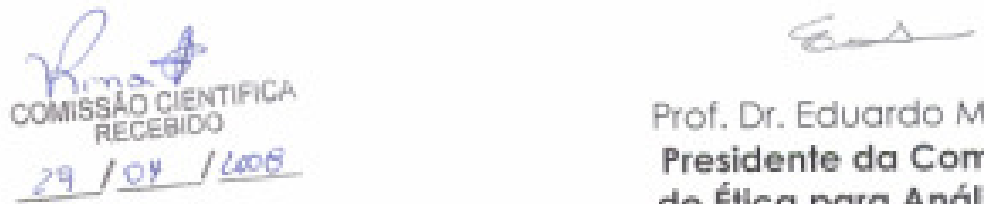

Prof. Dr. Eduardo Massad Presidente da Comissão de Éfica para Análise de Projetos de Pesquisa

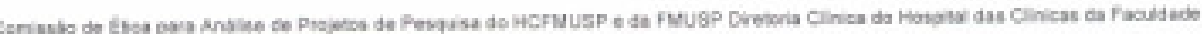

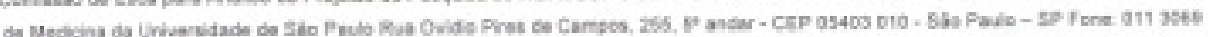

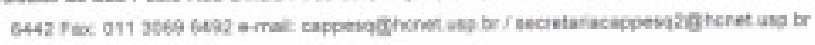




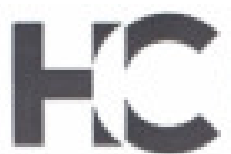

HOSPITHL DAS GHINCRS

DIRETORIA CLÍNICA

\section{Comissão de Ética para Análise de Projetos de Pesquisa}

\section{APROVAÇÃO}

A Comissão de Ética para Análise de Projetos de Pesquisa - CAPPesq da Diretoria Clínica do Hospital das Clínicas e da Faculdade de Medicina da Universidade de São Paulo, em sessão de 14.07.04, APROVOU o Protocolo de Pesquisa $n^{\circ}$ 527/04, intitulado: "Estuda da capacidade de transdiferenciação das células mesenquimais de tecido adiposo em células para reparaçäo cardiovascular" apresentado pela COMISSÃO CIENTÍFICA E DE ÉTICA DO INSTITUTO DO CORAÇÃO.

Pesquisador(a) Responsável: Prof. Dr. José Eduardo Krieger

Pesquisador(a) Executante: Sra. Juliana Sanajotti Nakamuta

CAPPesq, 14 de Julho de 2004.

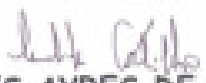

PROF. DR. EUCLIDES AYRES DE CASTILHO

Presidente da Comissão de Ética para Análise de Projetos de Pesquisa

\footnotetext{
OBSERVAÇÃO: Cabe ao pesquisador elabanar e apresentar d CAPPesq, as relatónios pareviais e final sobre a pesquisa (Resoluçalo do Canselho Nacional de Salide $n^{\circ} 196$, de 10.10.1996, inciso DX,2, letra "c'?
} 


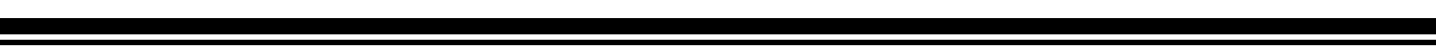




\section{Dados Pessoais}

$\begin{array}{ll}\text { Nome } & \text { Juliana Sanajotti Nakamuta } \\ \text { Nascimento } & 22 / 01 / 1981 \text { - Americana/SP - Brasil } \\ \text { CPF } & 21885535864\end{array}$

\section{Formação Acadêmica/Titulação}

2004 Doutorado em Cardiologia.

Universidade de São Paulo, USP, Sao Paulo, Brasil

Bolsista do (a): Fundação de Amparo à Pesquisa do Estado de São Paulo

2000 Graduação em Ciências Biológicas.

Universidade Estadual Paulista Júlio de Mesquita Filho, UNESP, São Paulo, Brasil

Título: Efeito da microinjeção direta de benzoato de estradiol no núcleo mediano da rafe sobre o comportamento de fêmeas no labirinto em cruz elevado Orientador: Telma Gonçalves Carneiro Spera de Andrade

Bolsista do (a): Fundação de Amparo à Pesquisa do Estado de São Paulo

\section{Atuação profissional}

1. Universidade Estadual Paulista Júlio de Mesquita Filho - UNESP

Atividades

09/2003 - 10/2003 Extensão Universitária, Faculdade de Ciências e Letras de Assis Especificação:

Organização e palestras "Deficiência Hormonal no Climatério" e "Aspectos Básicos sobre o Câncer"

05/2002 - 12/2003 Estágio, Faculdade de Ciências e Letras de Assis Monitoria no curso de Anatomia e Fisiologia Humanas

11/2001 - 12/2003 Estágio, Faculdade de Ciências e Letras de Assis Iniciação Científica em Fsiologia e Psicobiologia

09/2000 - 11/2001 Estágio, Faculdade de Ciências e Letras de Assis Estágio, Laboratório de Histologia e Embriologia

2. E E Profa. Lourdes Pereira - EEPLP

Atividades

10/2003 - 11/2003 Estágio, E E Profa. Lourdes Pereira

Aulas de reforço na disciplina de Biologia - Programa Escola da Família

\section{Produção em C, T\& A}


Produção bibliográfica

Artigos completos publicados em periódicos

1. $\quad$ Andrade, T.G.C.S., NAKAMUTA, J. S., Avanzi, V, Graeff, FG

Anxiolytic Effect of Estradiol in the Median Raphe Nucleus mediated by 5-HT1A Receptors. Behavioural Brain Research., v.163, p.18 - 25, 2005.

\section{Capítulos de livros publicados}

1. NAKAMUTA, J. S., Danoviz, ME, Gonçalves, GA, Krieger, JE

Mecanismos Moleculares da Resposta Adaptativa à Hipóxia In: Bases Moleculares das Doenças Cardiovasculares.1 ed.São Paulo : Atheneu, 2008, v.1, p. 499-504.

\section{Trabalhos publicados em anais de eventos (resumo)}

NAKAMUTA, J. S.; Faé, K. C.; Danoviz, M. E; Ramos, C. L.; Bassaneze, V.; Kalil, J.; Krieger, J. E. Shear Stress induces expression of endothelial cell surface markers in adipose-derived stem cells. In: International Symposium Of Advanced Therapies, 2007, Rio de Janeiro - RJ.

Santos-Júnior, G. R.; NAKAMUTA, J. S.; Danoviz, M. E.; Krieger, J. E.

Long-term culture of adipose-derived stem cells: Implications for cell therapy strategies. In: International Symposium Of Advanced Therapies, 2007, Rio de Janeiro - RJ.

Ferreira, D. S. C. G.1; NAKAMUTA, J. S.1; Bassaneze, V.1; Danoviz, M. E.1; Krieger, J. E1. Differentiation potential of murine adipose-derived stem cells along different passages. In: International Symposium Of Advanced Therapies, 2007, Rio de Janeiro - RJ.

Danoviz, M. E; NAKAMUTA, J. S.; Gonçalves, G.A.; Marques F.L.N.; Costa, E.L.F.; Schettert, I.; Krieger, J. E. Injectable biopolymers enhance cardiac retention of transplanted cells. In: International Symposium Of Advanced Therapies, 2007, Rio de Janeiro - RJ.

NAKAMUTA, J. S., Becker, C, Gonçalves, GA, Vassallo, PF, Marques, FN, Okamoto, M, Krieger, JE

Quantitative Assessment of Bone Marrow Cells Accumulation in the Heart Post IschemiaReperfusion Injury Following Injection By Different Routes In: XX Reunião Anula da Federação de Sociedades de Biologia Experimental - FeSBE, 2005, Águas de Lindóia - SP.

Anais da XX Reunião Anula da Federação de Sociedades de Biologia Experimental - FeSBE. , 2005.

Gonçalves, GA, Becker, C, Vassallo, PF, NAKAMUTA, J. S., Krieger, JE

Cardiac Fibroblast Expressing VEGF Prevents Cardiac Injury in Rats In: International Symposium Of Advanced Therapies, 2005, Rio de Janeiro - RJ. Proceedings of International Symposium Of Advanced Therapies., 2005.

Gonçalves, GA, Becker, C, Vassallo, PF, NAKAMUTA, J. S., Krieger, JE

Cardiac Fibroblast Expressing VEGF Prevents Cardiac Injury in Rats In: XX Reunião Anual da Federação de Sociedades de Biologia Experimental - FeSBE, 2005, Águas de Lindóia - SP.

Anais da XX Reunião Anual da Federação de Sociedades de Biologia Experimental - FeSBE. , 2005. 
NAKAMUTA, J. S., Becker, C, Gonçalves, GA, Vassallo, PF, Marques, FN, Okamoto, M, Krieger, JE

Quantitative Assessment of Bone Marrow Cells Accumulation in the Heart Post IschemiaReperfusion Injury Following Injection By Different Routes In: XX Reunião Anula da Federação de Sociedades de Biologia Experimental - FeSBE, 2005, Águas de Lindóia - SP.

Anais da XX Reunião Anula da Federação de Sociedades de Biologia Experimental - FeSBE. , 2005.

NAKAMUTA, J. S., Becker, C, Gonçalves, GA, Vassallo, PF, Marques, FN, Okamoto, M, Krieger, JE

Quantitative Assessment of Bone Marrow Cells Accumulation in the Heart Post IschemiaReperfusion Injury Following Injection By Differents Routes In: International Symposium of Advanced Therapies, 2005, Rio de Janeiro - RJ.Proceedings of I International Symposium of Advanced Therapies. , 2005.

Ferreira, M., NAKAMUTA, J. S.

Efeito da lesão do núcleo mediano da rafe sobre a manifestação de comportamentos agressivos em ratos In: VXIII Reunião Anual da Federação de Sociedades de Biologia Experimental FeSBE, 2003, Pinhais - PR.

VXIII Reunião Anual da Federação de Sociedades de Biologia Experimental - FeSBE. , 2003.

NAKAMUTA, J. S.

Efeito da microinjeção de benzoato de estradiol no núcleo mediano sa rafe sobre o comportamento de fêmeas no labirinto em cruz elevado In: I Mostra de Produção Científica em Biologia, 2003, Assis - SP.

I Mostra de Produção Científica em Biologia. , 2003.

Silva, F.R., NAKAMUTA, J. S.

Efeito da microinjeção direta de benzoato de estradiol no núcleo mediano da rafe sobre o comportamento de fêmeas no labirinto em T elevado In: I Mostra de Produção Científica em Biologia, 2003, Assis - SP.

Mostra de Produção Científica em Biologia. , 2003.

NAKAMUTA, J. S., Broiz, A.C.G., Silva, F.R., Andrade, T.G.C.S.

Efeito da microinjeção direta de benzoato de estradiol no núcleo mediano da rafe sobre o comportamento exploratório de fêmeas no labirinto em cruz elevado In: XVIII Reunião Anual da Federação de Sociedades de Biologia Experimental - FeSBE, 2003, Pinhais - PR.

XVIII Reunião Anual da Federação de Sociedades de Biologia Experimental - FeSBE. , 2003.

NAKAMUTA, J. S., Broiz, A.C.G., Silva, F.R., Andrade, T.G.C.S.

Efeito da microinjeção direta de benzoato de estradiol no núcleo mediano da rafe sobre o comportamento exploratório de fêmeas no labirinto em cruz elevado. In: XV Congreso de Iniciação Científica da Unesp, 2003, Marília.

XV Congreso de Iniciação Científica da Unesp. , 2003.

NAKAMUTA, J. S.

Palestra:"Neurobiologia do Estresse, Ansiedade e Depressão" In: I Mostra de Produção Científica em Biologia, 2003, Assis. Anais da I Mostra de Produção Científica em Biologia. , 2003. 


\section{Orientações e Supervisões}

Orientações e Supervisões em andamento

\section{Iniciação científica}

1. Gabriel Ribeiro dos Santos Junior. Estudo do crescimento populacional das células mesenquimais de tecido adiposo: implicações no fenótipo celular. 2007. Iniciação científica - InCor - HCFMUSP

2. Giancarlo Fatobene. Choque térmico como estratégia para melhorar a sobrevida de células-tronco do tecido adiposo transplantadas em modelo animal de infarto.2007. Iniciação Científica - InCor - HCFMUSP 